\title{
Effectiveness of the Beneficial Ownership Test in Conduit Company Cases
}

by

\section{Saurabh Jain}

\begin{abstract}
A thesis
submitted to Victoria University of Wellington in fulfilment of the requirements of the degree of Doctor of Philosophy in Commercial Law
\end{abstract}

Victoria University of Wellington 2012 



\begin{abstract}
Countries enter into double tax agreements with the economic objective of preventing double taxation of crossborder transactions. To achieve this objective, the contracting states agree reciprocally to restrict their substantive tax law. That is, a major policy of double tax agreements is to reduce double taxation of residents of states that are parties to the agreement. Residents of third states sometimes contrive to obtain treaty benefits typically by interposing a person or a conduit entity in one of the contracting states. In order to ensure that a resident of a contracting state who claims treaty benefits is entitled to them in substance, double tax agreements should be interpreted according to their substantive economic effect. Generally, double tax agreements follow the pattern of the OECD Model Tax Convention.

The OECD Model Convention addresses the double taxation of dividends, interest and royalties, commonly collectively known as "passive income", in Articles 10, 11 and 12 respectively. These provisions usually operate by reducing withholding tax imposed by a source state on passive income that flows from the source state to a resident state. In order to prevent a resident of a third state from obtaining a source state withholding tax reduction by interposing a person or a conduit entity in the resident state, the OECD Model Convention requires the immediate recipient of passive income to be the "beneficial owner" of that income. That is, the OECD Model Convention requires the immediate recipient to be an owner in a substantive economic sense.
\end{abstract}

Courts and commentators have difficulty in interpreting and applying the concept of beneficial ownership to conduit entities that are corporations, commonly referred 
to as "conduit companies". They have attributed the cause of the difficulty to the absence of a definition of the term "beneficial owner" in the OECD Model Convention. This thesis argues that the difficulty in applying the beneficial ownership concept to conduit companies has arisen not because of the absence of the meaning of the concept, but because logically and from an economic perspective the concept cannot be applied to companies in general, not to conduit companies in particular.

The beneficial ownership test was meant to be a test of economic substance. From an economic perspective, the benefit or the burden of a contract entered by a company is economically enjoyed or borne by its shareholders. That is, in substance a company cannot be considered as owning income beneficially. From this consideration, it follows that conduit companies can never be considered entitled to treaty benefits. Nevertheless, the OECD Model Convention applies the beneficial ownership test to conduit companies pursuant to an assumption that at least in some cases conduit companies can be the beneficial owners of passive income. The Model Convention's assumption is based on the legal perspective that courts conventionally adopt. According to this legal perspective, companies hold income beneficially because they exist as separate legal entities from their shareholders.

Courts find themselves battling these opposing perspectives when applying the beneficial ownership test to conduit companies. In order to make income tax law work efficiently, courts that are obliged to determine whether to honour claims to treaty benefits made by conduit companies have preferred to employ the legal perspective. Courts have justified this approach by adopting surrogate tests for the actual beneficial 
ownership test. Most of the surrogate tests do not relate to the concept of ownership at all. This thesis categorises the surrogate tests as "substantive business activity" and "dominion". By analysing reported cases, the thesis identifies deficiencies in these tests.

One of the proposed outcomes of the thesis is to suggest an alternative approach for deciding conduit company cases. The thesis suggests that courts should consider an arrangement as a whole and investigate reasons for the existence of an immediate recipient of passive income in the specific corporate structure. The thesis also recommends amendments in the official commentary on Articles 10,11 and 12 of the OECD Model convention in order to address the conceptual shortcomings inherent in those Articles. 



\section{Acknowledgements}

Throughout the course of this research, I have had the pleasure of knowing a number of people whose everwilling contribution in assorted ways to the research and the making of the thesis deserve special mention. It is a pleasure to convey my gratitude to them all in my humble acknowledgment.

This thesis owes its existence to the help, support, and inspiration of my supervisors, Professor John Prebble and Professor Kevin Holmes. No words are enough to express adequately my gratitude to them. I would like to thank them for their quality supervision, articulated advice and magnanimous guidance.

This thesis would not have been possible without the help, support and patience of my principal supervisor, Professor John Prebble. His unsurpassed knowledge and logical way of thinking have been of great value to me. His constructive criticism has profoundly shaped my analytical, research and writing skills. The advice and caring support of my second supervisor, Professor Kevin Holmes, have been invaluable both on an academic level as well as at a personal level, for which I am extremely grateful.

I would like to acknowledge the financial and technical support of the Victoria University of Wellington, particularly in awards of the Victoria $\mathrm{PhD}$ scholarship and the Victoria PhD Submission scholarship. The library facilities have been indispensable. I am grateful to Diane Hadley, Sheryl Robinson and Tracey Thomas, former librarians at the Law Library of Victoria University of Wellington, for helping me to find the original text of foreign language judgements referred to and quoted in this thesis. 
My special thanks go to Catharina van Bohemen for her valuable advice and time in helping me to revise and improve my prose. Many thanks go to Elizabeth O’Connor, Student Learning Support Service, Victoria University, for advising on my writing on a few occasions.

I have used the Google translator for translating certain Dutch, French and German cases, and legislation. Further, in order to ensure the accuracy of quotes, I consulted my colleagues and friends who speak these languages as their mother tongue. They deserve special mention for their efforts. Sincere thanks to Amandine Karem, Nicole Schlegel, René Andersen, Sanne Boer, Sarah Binder and Stephan Gerschewski. For any errors or inadequacies that may remain in this work, of course, the responsibility is entirely mine.

Where would I be without my family? My parents, sister and nephew have given me their unequivocal support throughout, as always, for which my mere expression of thanks does not suffice. Without their ungrudging support and understanding, it would have been impossible for me to complete this work.

I wish to express my deep and sincere gratitude to Dr. Bhagwan Khanna, who has always provided me with unflinching encouragement and support in various ways since my joining the doctoral programme. I am indebted to him much more than he knows.

My heartfelt gratitude and thanks go out to my best friend Roopa Navalpakam for showing unwavering confidence in me, and for extending her unconditional support throughout this thesis. Despite being involved in her own thesis, she took time out on various occasions for listening to me and advising me on my thesis. 
I owe my loving thanks to Jane Upton, Margaret Slessor and their families for their kindness, friendship and support.

Last, but by no means least, thank you God, Universe, Reiki energy and my Angels for all experiences of the past four years of my life. 



\section{Table of Contents}

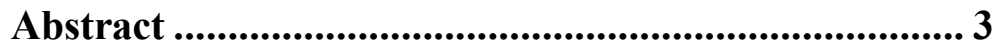

Acknowledgements........................................................ 7

1. Introduction ............................................................. 17

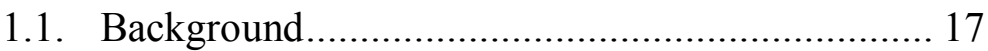

1.2. Problem in applying the beneficial ownership test 20

1.3. Surrogate tests: an imaginary connection.............. 22

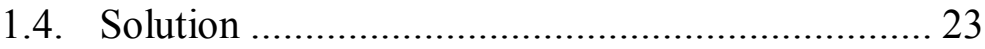

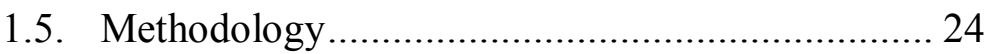

1.6. Scope of the study ............................................ 24

1.7. Conduit companies strategies ............................. 26

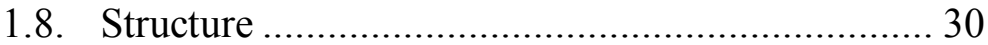

1.9. Original contribution ............................................ 30

1.10. Economic and political implications .................... 31

2. Confusions of the legalistic approach ................. 35

2.1. Introduction ................................................... 36

2.2. Interpretation of double tax conventions .............. 37

2.3. Beneficial ownership test in the OECD Model Convention......................................................... 40

2.4. Aiken Industries Inc $v$ Commissioner of Internal Revenue .............................................................. 41

2.5. Aiken Industries: the interpretation of the term "beneficial owner" .............................................. 44

2.6. N AG v Regional Tax Officer for Upper Austria .... 46

2.7. The $N A G$ case: the interpretation of the term "beneficial owner" .............................................. 48

2.8. "Beneficial owner": ordinary meaning ................ 48

2.9. The $\operatorname{Re} V S A$ case .............................................. 50

2.10. Re V SA: ordinary meaning of "beneficial ownership" 52

2.11. "Beneficial owner": legal meaning ....................... 54

2.12. "Beneficial ownership": English law meaning...... 56

2.13. Analogy between the ordinary and legal meaning of the term "beneficial owner".................................. 59

2.14. To what extent can the beneficial ownership concept be incorporated in double tax conventions? .......... 60

2.15. The conventional legal view ................................ 61

2.16. Eisner v Macomber ............................................. 62

2.17. The Macomber case: interpretation of beneficial ownership ...................................................... 64

2.18. The "separate entity theory" and conduit companies

2.19. The economic perspective ..................................... 65

2.20. Aiken Industries: an economic approach.............. 67

2.21. The $N A G$ case: an economic approach................. 67 
2.22. Economic perspective: companies can never be entitled to treaty benefits ..................................... 68

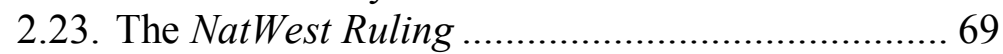

2.24. The NatWest Ruling: paradoxical perspectives...... 71

2.25. Ectopia: dislocation between the beneficial ownership test and conduit companies................. 73

2.26. Application of the beneficial ownership test to conduit companies by the OECD.......................... 75

2.27. Why does the OECD assume that conduit companies are capable of being the beneficial owners of passive income? .............................................................. 75

2.28. Application of the beneficial ownership test to conduit companies by courts .............................. 77

2.29. Why do courts apply the beneficial ownership test to conduit companies? ............................................. 78

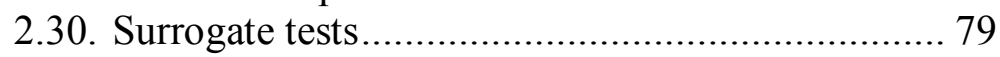

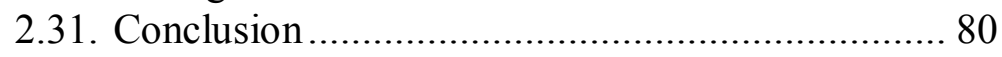

3. Substance based approach ....................................83 83

3.1. Introduction ..................................................... 83

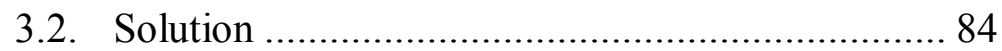

3.3. L.J. Newton v Federal Commissioner of Taxation 86

3.4. How should the word "beneficial" be interpreted? 89

3.5. The Y-group 1990 case ...................................... 90

3.6. Y-group 1990: the word "beneficial" ................... 92

3.7. Y-group 1990: operation of the logic of the term

"beneficial" and the predication test .................... 94

3.8. The Re V SA case ................................................ 95

3.9. Re $V S A$ : the word "beneficiary" ......................... 98

3.10. Re $V S A$ : similarity between the logic of the term "beneficial" and the predication test ..................... 99

3.11. Similarity between the function of the word "beneficial" and the predication test ................... 102

3.12. The $X$-group 1979 case ................................... 104

3.13. "Means of the arrangement" and not "the motive of

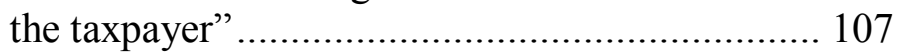

3.14. "Arrangement": totality of facts ......................... 108

3.15. The Arabian-group 1984 case .......................... 110

3.16. Interpretation of the anti-abuse clause under Article

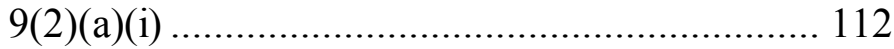

3.17. Significance of the existence ............................ 112

3.18. Conclusion...................................................... 113

4. Substantive business activity ............................ 117

4.1. Introduction ................................................ 118

4.2. The OECD on substantive business activity and beneficial ownership ...................................... 119

4.3. A Holding ApS v Federal Tax Administration..... 122

4.4. Beneficial ownership and the abuse of law doctrine 
4.5. Beneficial ownership and the substantive business activity test. 126

4.6. Is business activity a sufficient criterion for deciding conduit company cases? 127

4.7. Is substantive business activity originally a test for deciding conduit company cases? ..................... 128

4.8. Straw corporations ........................................... 129

4.9. Difference between straw corporations cases and conduit company cases ................................... 131

4.10. Base companies................................................ 132

4.11. Why is substantive business activity a test for base company cases?................................................ 134

4.12. Difference between base company cases and conduit company cases ................................................. 135

4.13. Northern Indiana Public Service Company $v$ Commissioner of Internal Revenue ..................... 137

4.14. Northern Indiana: an illogical analogy ............... 139

4.15. Moline Properties Inc v Commissioner of Internal Revenue 141

4.16. Difference between Northern Indiana and Moline Properties .......................................................... 142

4.17. Hospital Corporation of America v Commissioner of Internal Revenue .............................................. 144

4.18. Difference between Northern Indiana and Hospital Corporation of America .................................... 146

4.19. Section 50d(3) of the German Income Tax Act... 148

4.20. The G-group 2002 case .................................. 151

4.21. G-group 2002: another analogy with base company cases ........................................................... 153

4.22. Is business activity a conclusive criterion for deciding conduit company cases? ...................... 154

4.23. The G-group 2005 case ................................... 155

4.24. Interpretation of section $50(\mathrm{~d})$ in the light of base company cases .............................................. 157

4.25. What constitutes substantive business activity? .. 160

4.26. Does profit spread indicate business activity?.... 161

4.27. Revenue Ruling 84-153: profit spread is not relevant at all ............................................................ 164

4.28. Reasons for the existence of Finance ................. 167

4.29. Can holding shares constitute a business activity? 169

4.30. Reasons for the existence of the Dutch subsidiaries

4.31. The amended section 50d(3) of the EStG............ 173

4.32. The Bank of Scotland case................................ 175

4.33. Would section $50 \mathrm{~d}(3)$ have worked in the facts and circumstances of Bank of Scotland?................... 178

4.34. Conclusion.......................................................... 179

5. Dominion........................................................... 181 
5.1. Introduction

5.2. Paragraph 14(b) of the Conduit Companies Report

5.3. Conceptual and linguistic confusions................. 184

5.4. "Narrow powers": the absence of dominion........ 185

5.5. The obligation to pass on passive income in property law

5.6. Bank of Scotland: the absence of an obligation in property law is indecisive 188

5.7. Obligation to pass on passive income in contract law 191

5.8. Aiken Industries: complete dominion and control 191

5.9. The Indofood case 194

5.10. Indofood: the presence of a contractual obligation and beneficial ownership.... 198

5.11. The example of a "nominee or agent" as conduit: a fallacy 201

5.12. Royal Dutch Shell 203

5.13. Reasons for the existence of X Ltd ................... 206

5.14. The Prévost Car case ...................................... 208

5.15. Prévost Car: dominion an indicator of beneficial ownership 210

5.16. Prévost Car: analogy between nominees and agents, and conduit companies

5.17. Prévost Car: analogy between the beneficial ownership test and piercing the corporate veil .... 213

5.18. Reasons for the existence of Dutch BV............... 215

5.19. Conclusion.................................................... 217

6. The Step transaction doctrine ......................... 219

6.1. Introduction ....................................................... 220

6.2. The step transaction doctrine ............................ 222

6.3. The binding commitment test ........................... 224

6.4. The end-result test........................................... 224

6.5. The mutual-interdependence test ...................... 226

6.6. The Del Commercial case ................................ 226

6.7. Del Commercial: a comparison with the Northern Indiana case .................................................... 229

6.8. Del Commercial: the step transaction doctrine.... 231

6.9. Del Commercial: the step transaction doctrine and beneficial ownership ......................................... 232

6.10. The $W$-family 1 case ....................................... 234

6.11. W-family 1: the step transaction doctrine ........... 236

6.12. W-family1: link between transactions and tax avoidance......................................................... 238

6.13. W-family 1 : the step transaction doctrine and beneficial ownership ........................................ 238

6.14. Link between transactions: an indecisive approach 240 
6.15. Del Commercial: did courts consider the arrangement as a whole? ................................... 241

6.16. The Indofood case ........................................... 242

6.17. Del Commercial: narrow and technical approach 245

6.18. The SDI Netherlands case .................................. 246

6.19. The "flow-through characterisation concept"...... 248

6.20. The "flow-through characterisation concept" and link between transactions ................................. 250

6.21. The "flow-through concept" and the "conduit concept": an analogy ........................................ 251

6.22. The court's interpretation of Aiken Industries and Northern Indiana ............................................ 253

6.23. Similarity in terms and conditions ..................... 254

6.24. Close relationship.......................................... 255

6.25. Reasons for existence of SDI Netherlands .......... 257

6.26. $W$-family 1: deviation from the reasons for existence

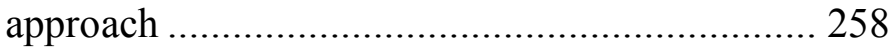

6.27. The Y-group 1990 case................................... 259

6.28. W-family 1: did the court consider the arrangement in its entirety? ................................................ 260

6.29. The $W$-family 2 case .......................................... 261

6.30. The $X$-group 1979 case .................................. 265

6.31. Consideration of the arrangement as a whole...... 267

6.32. Reasons for the existence of Antillean NV .......... 268

6.33. Conclusion...................................................... 270

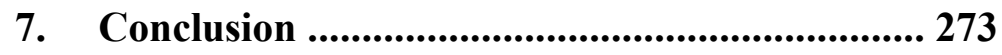

7.1. The underlying theory .................................... 273

7.2. A pragmatic position ........................................ 275

7.3. Difficulties for courts ...................................... 276

7.4. The nature of general anti-avoidance rules ........ 278

7.5. The nature of the beneficial ownership clause .... 280

7.6. Narrow approach does not help ........................ 283

7.7. Significance of the term "beneficial owner" ....... 286

7.8. "Beneficial owner": a distraction in conduit company cases ................................................ 290

7.9. "Reasons for existence": an alternative approach 293

7.10. Beneficial ownership is not an additional requirement ................................................... 295

7.11. The "activity provision" .................................... 298

7.12. Reference to paragraph 14(b) of the Conduit Companies Report............................................ 301

7.13. The OECD's discussion draft on the clarification of the meaning of the term "beneficial owner"........ 304

7.14. Future implications ........................................ 307

Appendix..................................................................... 309

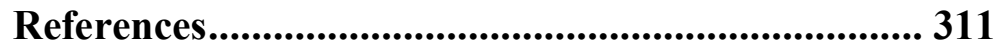




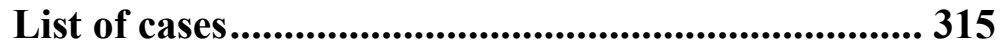

The OECD Documents ............................................ 319

Statutory and parliamentary references ................... 321

Treaties and directives ............................................ 323 


\section{CHAPTER 1}

\section{INTRODUCTION}

1. Introduction ..................................................... 17

1.1. Background ........................................................ 17

1.2. Problem in applying the beneficial ownership test 20

1.3. Surrogate tests: an imaginary connection.............. 22

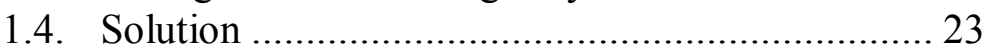

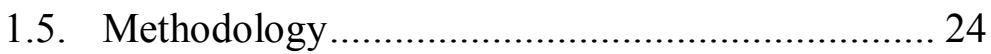

1.6. Scope of the study ........................................... 24

1.7. Conduit companies strategies .............................. 26

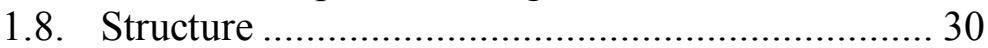

1.9. Original contribution ........................................... 30

1.10. Economic and political implications .................... 31

\subsection{Background}

Most countries tax income on the basis of both residence and source. As a result, cross-border transactions may be taxed twice, both in the source country and in the country of residence. This phenomenon is known as "double taxation". Countries may avoid this problem either unilaterally by legislation that relieves certain income from tax or bi-laterally (or multi-laterally) by entering double taxation treaties ${ }^{1}$ with countries with which they have trading or investment relationships. Such treaties almost invariably contain articles that address the taxation of dividends, interest, and royalties (commonly collectively known as "passive income"), which flow from a source in one treaty partner to a resident in the other treaty partner. Tax treaties usually operate by partially, or fully, exempting passive income from withholding tax imposed by the source country. Treaty partners intend that treaty benefits should be granted to their residents, not to residents of non-contracting states. Moreover, they intend benefits to be granted to persons who enjoy the benefits,

\footnotetext{
${ }^{1}$ Double tax treaties are also referred as "double taxation agreements" or "double tax conventions" and simply as "tax treaties".
} 
not to an artificial entity that is interposed in a stream of income. A question that arises from this framework is do residents of treaty partners who receive passive income qualify for this reduction in withholding tax.

Most countries that negotiate double taxation agreements follow the pattern of the model tax convention on income and on capital formulated by the Organisation for Economic Co-operation and Development ${ }^{2}$ (which will be referred to as "the OECD Model Convention") or a similar pattern. ${ }^{3}$ The provisions of the OECD Model Convention that apply to dividends, interest, and royalties are respectively Articles 10, 11, and 12. Articles 10(2), 11(2), and 12(1) address the question of the qualification for benefits under the treaty. The test that each of these articles applies is "beneficial ownership". Treaties sometimes use terms such as "beneficial owner", 4 "beneficially entitled", "beneficially owned"6 and "beneficial interest". ${ }^{7}$ These terms are all variations of the notion of beneficial ownership.

${ }^{2}$ OECD Committee on Fiscal Affairs Model Tax Convention on Income and on Capital (OECD, Paris, 2010).

${ }^{3}$ For example, United Nations Department of Economic and Social Affairs "United Nations Model Double Taxation Convention between Developed and Developing Countries" ST/ESA/PAD/SER.E/21 (2001).

${ }^{4}$ For example, Convention for Avoidance of Double Taxation and the Prevention of Fiscal Evasion with Respect to Taxes on Income, the Netherlands-Indonesia (29 January 2002, entered into force 1 January 2004), art 10(2).

${ }^{5}$ For example, Convention for the Avoidance of Double Taxation and the Prevention of Fiscal Evasion with Respect to Taxes on Income, Canada-Australia (21 May 1980), art 10(1).

${ }^{6}$ For example, Convention for Avoidance of Double Taxation and the Prevention of Fiscal Evasion with Respect to Taxes on Income and Capital Gains, the United Kingdom-the Netherlands (7 November 1980), art 10(1).

${ }^{7}$ For example, Convention for the Avoidance of Double Taxation and the Prevention of Fiscal Evasion with Respect to Taxes on Income and Capital, United States-France (31 August 1994), art 30(4)(c). 
The OECD Model Convention does not define the term "beneficial owner". Ever since the introduction of the term in the Model Convention of 1977, its meaning has been a topic of debate. For instance, at the 1998 International Fiscal Association Congress in London, the topic of discussion in one of the seminars was "The Concept of Beneficial Ownership in Tax Treaties". ${ }^{8}$ The first question raised in that seminar was, "Should the domestic law of the contracting state be referred to under Article 3(2) of the OECD Model Convention to understand beneficial ownership, or does the context of Articles 10, 11, and 12 of the OECD Model Convention require that beneficial ownership be interpreted as a concept of international tax language, which is separate from domestic law?" The second issue was, "If the concept of beneficial ownership is not seen as a reference to domestic law, then how should the concept be interpreted? What then is beneficial ownership?"9

The 2002 OECD report on restricting the entitlement of treaty benefits ${ }^{10}$ discusses the background of the amendments in the commentary on Articles 10,11 and 12 of the Model Convention adopted on 28 January 2003. In this report, the OECD Committee on Fiscal Affairs expressed the opinion that the difficulties in interpreting and applying the concept of beneficial ownership had arisen because of the absence of an extensive clarification

\footnotetext{
${ }^{8}$ Klaus Vogel The OECD Model Convention, 1998 and Beyond: the Concept of Beneficial Ownership in Tax Treaties: Proceedings of a Seminar held in London in 1998 during the 52nd Congress of the International Fiscal Association (Kluwer Law International, London, 2000).

${ }^{9}$ See also Charl P du Toit Beneficial Ownership of Royalties in Bilateral Tax Treaties (IBFD, Amsterdam, 1999) at 17.

${ }^{10}$ OECD Committee on Fiscal Affairs "Restricting the Entitlement to Treaty Benefits" in OECD Committee on Fiscal Affairs 2002 Reports Related to the OECD Model Tax Convention (OECD, Paris, 2003) at 9.
} 
of the concept. ${ }^{11}$ On 29 April 2011, the OECD Committee on Fiscal Affairs published a discussion draft that proposed changes in the official commentary on Articles 10,11 and 12 with an aim of clarifying the meaning of the term "beneficial owner". ${ }^{12}$ Similarly, many other studies on the concept have expressed a need to define the term beneficial ownership. ${ }^{13}$

Thus, the general view is that the term beneficial ownership needs to be clarified. However, this view overlooks an important issue, which is whether the concept of beneficial ownership is logically capable of being applied to the problem that it is meant to solve. This thesis addresses that issue and argues that the difficulty in the application of the concept has arisen not because of the absence of a meaning of the concept in international tax law, but because logically and from an economic perspective the concept is incapable of being applied as a test to many of the circumstances where it is required to operate, most notably where the recipient of income is a corporation, shareholders of which reside in a noncontracting state. This chapter will refer to such corporations as "interposed companies".

\subsection{Problem in applying the beneficial ownership test}

As indicated earlier, double tax agreements operate to mitigate double taxation of transactions only between residents of contracting states. In the light of this policy,

${ }^{11}$ The Restricting the Entitlement to Treaty Benefits Report, at para 23.

${ }^{12}$ OECD Committee on Fiscal Affairs Clarification of the Meaning of "Beneficial Owner" in the OECD Model Tax Convention: Discussion Draft (OECD, Paris, 2011)

${ }^{13} \mathrm{Du}$ Toit above n 9. J David B Oliver and others "Beneficial Ownership" (2000) 54 Bulletin for International Taxation 310. John F Avery Jones and others "The Origin of Concepts and Expressions Used in the OECD Model and their Adoption by States" (2006) 60 Bulletin for International Taxation 220, at 246. 
the term "beneficial owner" should logically mean owner in a substantive economic sense. English trust law also uses the concept of beneficial ownership to distinguish someone who has the substantive right to enjoy the property from someone who looks after it. It follows that the concept of beneficial ownership is to be used as an economic principle rather than applying a narrower inappropriate meaning.

The concept of beneficial ownership emphasises the economic reality of the relationship between corporations and shareholders, according to which a corporation is merely a legal fiction that cannot be considered separately from its shareholders. It is, therefore, not capable of holding property substantively. An economic perspective suggests that tax levied on a corporation's income should be integrated with any tax levied on its shareholders.

That is, it should never be entitled to treaty benefits applicable to passive income because beneficial ownership requires determination of who is ultimately better off as a result of the payment of income, regardless of who or what is the immediate recipient. Thus, there is no connection between the concept of beneficial ownership and the notion of companies.

This lack of connection is problematic particularly in situations involving interposed companies. Nevertheless, the OECD and courts apply the beneficial ownership test to such companies with the view that, at least in some cases, companies are entitled to treaty benefits because they are the beneficial owners of the income in question.

The approach adopted by the OECD and courts corresponds to the conventional legal point of view, according to which a corporation exists as a legal personality separately from its shareholders. It can own 
assets and derive income from them. From the legal perspective, therefore, income tax should be levied on a corporation, not on its shareholders.

Applying beneficial ownership test to interposed companies from the legal perspective may result in treaty benefits being passed on to residents of a non-contracting state. That is, double tax treaties tend to operate in a manner that contradicts their own policy, which is to limit tax benefits to residents of contracting states. In other words, interposed companies distort the general application of the tax treaty policy.

\subsection{Surrogate tests: an imaginary connection}

The OECD and courts have drawn an imaginary connection in determining whether the limitation on a source country's taxing rights, embodied in a double tax treaty, can be used effectively by an interposed company to mitigate the effects of the source state's domestic tax law. In order to justify their view, they have adopted surrogate tests of the actual beneficial ownership test when applying it to interposed companies, which are substantive business activity and dominion.

These surrogate tests do not indicate the presence of beneficial ownership. For example, the business activity test investigates whether a conduit company has a business activity of its own. Logically, however the simple presence of a business activity does not indicate the presence of ownership, let alone beneficial ownership. Moreover, these tests are inappropriate for determining the correct tax treatment of passive income (in the form of dividends, interest, or royalties) derived by interposed companies because they were originally meant to counter different kinds of tax planning strategies. Nevertheless, courts have inappropriately applied them as the beneficial 
ownership test referred to in Articles 10,11 and 12 of the OECD Model Convention. That is, they do not distinguish surrogate tests from the beneficial ownership test. Instead of clarifying the definition of beneficial ownership, their interpretation has led to the opinion that the concept needs clarification.

\subsection{Solution}

The most radical solution may be to redraft the relevant provisions of the OECD Model Convention. Another possibility may be to insert limitation of benefits clauses, which certain countries such as the United States use to overcome confusion in interpreting and applying the concept of beneficial ownership. Implementing these changes would take a long time because renegotiating and redrafting double tax treaties is a lengthy process, but until they are amended confusion prevails.

This thesis tries to find short- and medium-term solutions. It highlights an alternative approach adopted by Dutch and Swiss courts for deciding certain conduit company cases. These courts determined whether an intermediary was interposed to act as a conduit by investigating reasons for the existence of the intermediary in the corporate structure. Their approach resembles the "predication test" adopted by Lord Denning in Newton $v$ Federal Commissioner of Taxation. ${ }^{14}$ According to this test courts should examine what was really done, not simply look at documents. As a result, if it could be predicated that the arrangement was implemented to reduce the withholding tax imposed in the source state, the source state's domestic withholding tax rate would apply to the relevant passive income.

\footnotetext{
${ }^{14}$ Newton v Federal Commissioner of Taxation (1958) 98 CLR 1.
} 


\subsection{Methodology}

This thesis is a doctrinal study of relevant case law in various jurisdictions. It analyses the problem of interpreting the term "beneficial owner". This problem has arisen because of the difficulty of applying the tax treaty policy to interposed companies. The difficulty in applying the policy can be analysed by examining the reasoning by which law applies to different facts. The reasoning is found in courts' judgments; hence, the thesis is based on case analysis. This thesis examines lapses in logic, which have led courts to interpret the term improperly. The analysis leads to new insights that provide effective suggestions for the operation of the beneficial ownership test.

The thesis steps from the doctrinal analysis to policy analysis when it draws its conclusions. It examines the official commentary on Articles 10, 11 and 12 of the OECD Model Convention in the light of the intention of the OECD Committee of Fiscal Affairs to use the term "beneficial owner". In examines the work of the committee before the insertion of the term. It suggests appropriate amendments to relevant parts of the official commentary on the convention.

\subsection{Scope of the study}

The investigation is international and applies the principles of international tax law, although refers to relevant domestic tax law of specific states when necessary. This thesis refers to the OECD Model Convention and its provisions for the purposes of interpreting the term "beneficial owner". ${ }^{15}$ The United

\footnotetext{
${ }^{15}$ The OECD Model Convention, above $\mathrm{n} 2$.
} 
Nations Model Tax Convention ${ }^{16}$ also uses the term. In respect of the term beneficial owner the language and context of the provisions of both the OECD Model Convention and the United Nations Model Convention is the same. ${ }^{17}$ Thus, the conclusions drawn from the analysis of the concept of beneficial ownership given in the OECD Model Convention can also be applied to the United Nations Model Convention.

This thesis concentrates on the OECD Model Convention. It focuses on bilateral tax treaties and does not consider multi-lateral tax agreements.

Articles 10(2), 11(2) and 12(1) of the OECD Model Convention use the term "beneficial owner" as a countermeasure against tax planning schemes in which residents of a third state interpose an entity in a contracting state to obtain benefit of a withholding tax reduction provided by the convention. The entity can be a corporation, a partnership, or a trust. This thesis concentrates on corporations, which are commonly referred to as conduit companies, and analyses conduit company cases from different jurisdictions, the most recent being Her Majesty the Queen v Prévost Car Inc, ${ }^{18}$ which was decided by the Canadian Federal Court of Appeal on 17 February 2009. Although there are other tax planning arrangements that use interposed companies in order to obtain treaty benefits, ${ }^{19}$ the thesis focuses on the

\footnotetext{
${ }^{16}$ The United Nations Model Double Taxation Convention, above n 3.

${ }^{17}$ Ibid, at 144-198. The United Nations Model Convention follows the OECD Model Convention and reproduces parts of the commentary on the provisions of the OECD Model Convention.

${ }^{18}$ Her Majesty the Queen v Prévost Car Inc 2009 FCA 57.

${ }^{19}$ For example, "Artiste companies", which are dealt with under Article 17 of the OECD Model Convention. "Typical triangular" cases as defined in OECD Committee on Fiscal Affairs "Triangular Cases" in OECD Committee on Fiscal Affairs Model Tax Convention: Four
} 
improper use of the convention through conduit companies.

\subsection{Conduit companies strategies}

Broadly, a conduit company can be described as a company interposed between a company that pays (passive) income from a source state with which the country of the residence of the conduit company has a double tax agreement, and a company (or owner) resident in another state which cannot avail itself of benefits of the treaty.

To illustrate, a company that is resident in State $\mathrm{R}$ derives passive income in the form of dividends, interest, or royalties from the assets and rights (for example, respectively, shares in, loans to, or the use of intellectual property rights given to) in a source company, which is a resident in State S. If there is no tax treaty between States $\mathrm{R}$ and $\mathrm{S}$, State $\mathrm{S}$ imposes withholding tax under its domestic law on the passive income paid by the source company to the resident company. However, suppose that State $\mathrm{S}$ has a treaty with State $\mathrm{C}$, which reduces withholding tax on the passive income paid by companies that are resident in State $\mathrm{S}$ to companies that are resident in State C. In addition, assume for the convenience of this illustration that foreign sourced passive income is taxexempt in State C. ${ }^{20}$

Related Studies, Issues in International Taxation, No 4 (OECD, Paris, 1992) 28, at para 2.

${ }^{20}$ For example, State $\mathrm{C}$ might include the dividends, interest or royalties within its residents' gross taxable income but allow a deduction for dividends, interest, or royalties, when paid by the intermediary to the resident company. Sometimes in practice the intermediary must request an exemption from State $\mathrm{C}$ or tax relief from State S. 


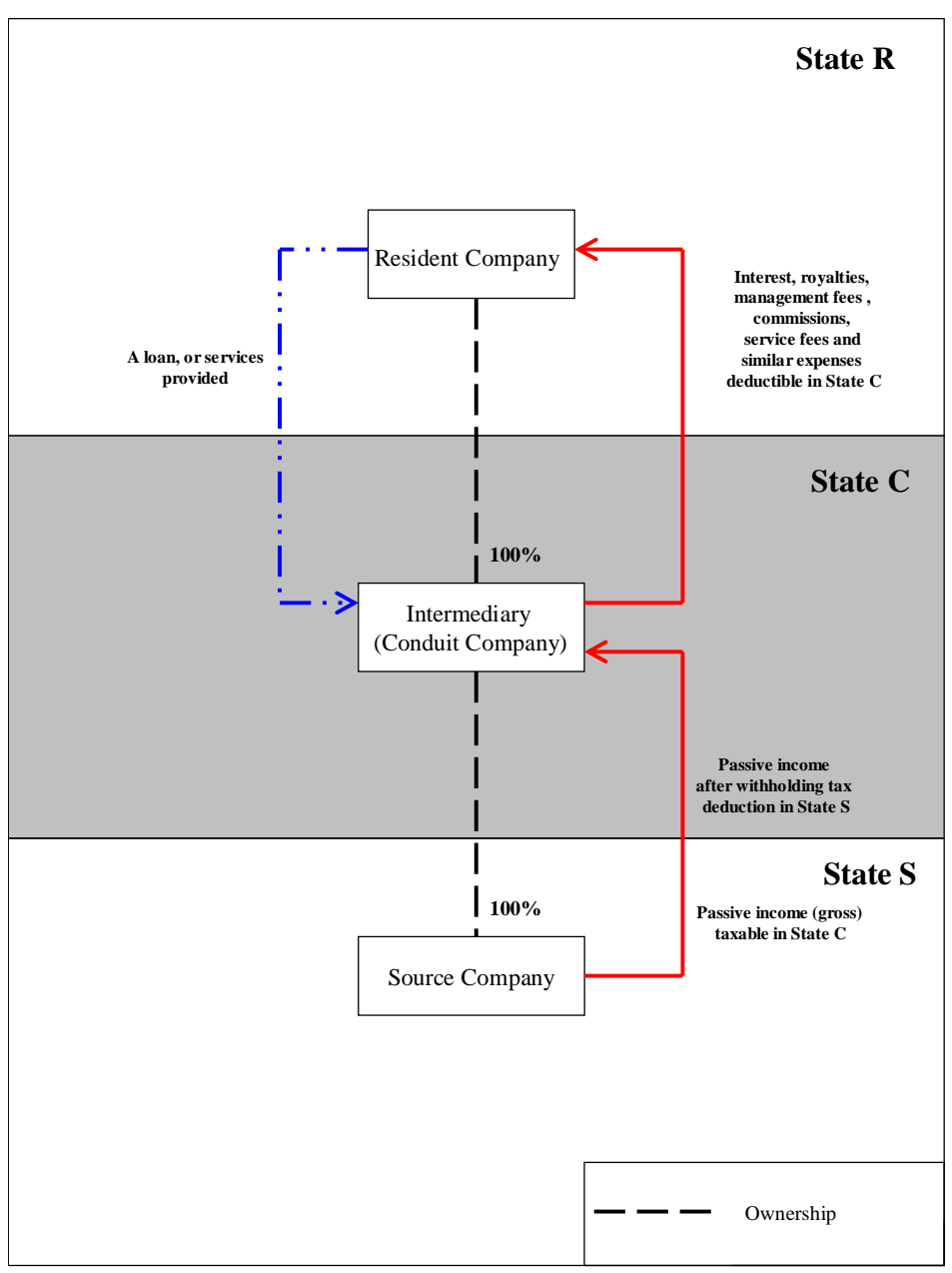

Figure 1.1: Direct conduit

To take advantage of the withholding tax reduction, the resident company incorporates a wholly owned intermediary company in State C and transfers ownership of all its assets and rights in the source company to the intermediary. As the legal owner of the passive income, the intermediary claims relief from the domestic withholding taxes of State S. The intermediary then passes on the income to the resident company. That is, the intermediary based in State $\mathrm{C}$ acts as a conduit company for channelling income from State $S$ to the ultimate owner in State $\mathrm{R}$ to reduce withholding tax impost in State $\mathrm{S}$. The OECD report on double tax conventions and conduit 
companies $^{21}$ refers to such type of tax planning structures as a "direct conduit".

Often in conduit company strategies, tax savings do not rely on tax exemptions in the intermediary state alone. Tax savings can be obtained from the combined effect of the withholding tax reduction under a double tax treaty and the domestic law tax provisions of the intermediary state. The Conduit Companies Report refers to such strategies as "stepping stone conduits". 22

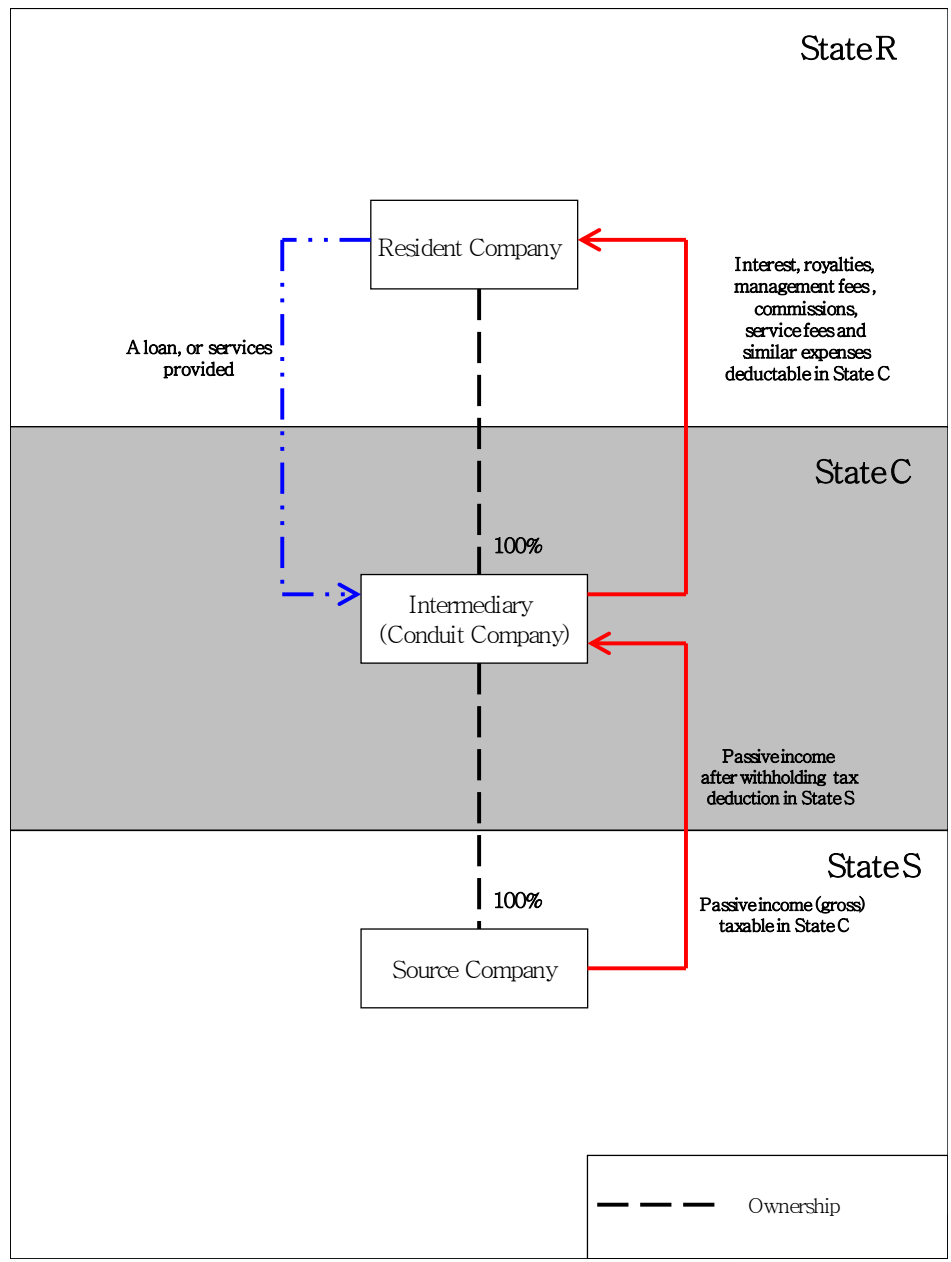

Figure 1.2: Stepping stone conduit

${ }^{21}$ OECD Committee on Fiscal Affairs "Double Taxation Conventions and the Use of Conduit Companies" in OECD Committee on Fiscal Affairs International Tax Avoidance and Evasion: Four Related Studies, Issues in International Taxation No 1 (OECD, Paris, 1987) 87, at para 4(1). See Figure 1.1.

${ }^{22}$ The Conduit Companies Report, at para 4(2). See Figure 1.2. 
In a stepping stone conduit strategy, the basic structure is identical to the direct conduit scheme. The main difference is that in the stepping stone conduit strategy, State $\mathrm{C}$ includes the passive income received by the intermediary from the source company in the intermediary's gross taxable income. Under the general tax provisions of State $\mathrm{C}$ the intermediary is then allowed a full deduction for the income that it passes on to the resident company. The income that the intermediary passes on to the resident company may be a (high) interest payment in a case of back-to-back loan structure, or in the form of royalties, commissions, or management or service fees. In effect, the intermediary does not bear any tax in State C.

While the tax avoidance strategies in most of the decisions that this thesis analyses essentially correspond to either direct conduit or stepping stone conduit schemes, the thesis also analyses cases in which the conduit companies are totally unrelated to the corporations in the residence and source countries. ${ }^{23}$

Thus, a conduit company is interposed between the source state and the resident state with the purposes of:

1. avoiding or reducing source state withholding tax by obtaining the benefit of the (partial or full) withholding tax exemption under the treaty between the source state and the state where the conduit company is located; and

2. passing on the income subject to the source state withholding tax concession to the taxpayer in the residence state.

${ }^{23}$ For example, Ministre de l'Economie, des Finances et de l'Industrie v Société Bank of Scotland (2006) 9 ITLR 683 (Conseil d'État, France), and Royal Dutch Shell (6 April 1994) Case no 28 638, BNB 1994/217 (the Hoge Raad, the Netherlands). 


\subsection{Structure}

The thesis begins by analysing the term "beneficial owner" in the context of the object and purpose of the OECD Model Convention. The analysis explains the reason for the difficulty of applying the term to conduit companies. The thesis proposes that the concept of beneficial ownership does not apply logically to conduit companies because it does not apply to any company in a substantive economic sense. It also delineates certain tests that courts have substituted for the actual beneficial ownership test and applied to conduit company cases.

Subsequently, the thesis highlights a substance based approach for dealing with conduit company cases. Applying this approach as a benchmark, it examines the effectiveness of surrogate tests by analysing judgments of courts of different countries. Case analysis highlights deficiencies of the surrogate tests. The thesis concludes by suggesting appropriate amendments in the relevant parts of the official commentary on the OECD Model Convention.

\subsection{Original contribution}

As discussed earlier, the thesis analyses the reasoning of courts of various countries. It consolidates and categorises cases and material according to the surrogate tests courts apply for the actual beneficial ownership test. It translates and reviews extracts of judgements that have been overlooked. It highlights subtle differences in reasoning, which can change the outcome of a case.

The thesis challenges certain sources generally regarded as yardsticks for interpreting the term "beneficial owner". For example, it analyses paragraph 14(b) of the Conduit Companies Report and the Royal Dutch Shell 
case, which are referred to widely for determining the meaning of the term.

The thesis suggests new perspectives and insights. For example, contrary to general opinion, it shows that courts in common and civil law jurisdictions have adopted similar reasoning in the interpretation of the term "beneficial owner".

\subsection{Economic and political implications}

The term "beneficial owner" has enormous political and economic implications. Political impact is apparent from the national positions that certain countries have developed in terms of their tax treaty policy, in order to attract multinational investments. Widespread tax avoidance shows the scale of the economic impact of these policies.

For example, in December 1998, the Danish Ministry of Taxation abolished limited tax liability on dividends distributed by Danish subsidiaries to all foreign parent companies. ${ }^{24}$ As a result, Denmark turned into a tax haven for intermediary holding companies. When the European Union criticised Denmark for unfair tax competition, the Ministry limited the application of the exemption of the limited tax liability to companies within the European Union and to companies in countries with which Denmark had double tax treaties. ${ }^{25}$ However, in the interpretive notes to the amending Act, the ministry directed that Danish withholding tax could be avoided by interposing a holding company in another member state of the European Union or in a contracting state of Danish double tax

\footnotetext{
${ }^{24}$ Act No 1026 of 23 December 1998.

${ }^{25}$ Act No 282 of 25 April 2001.
} 
treaties. Many multinationals, therefore, followed the direction and established holding companies in Denmark.

Denmark underestimated the significance of the beneficial owner test in its double tax treaties. As a consequence, it not only lost tax revenue, but also caused other countries to lose theirs.

In 2005, Denmark changed its policy retrospectively. It has since clarified that it intends to grant the exemption from limited tax liability only in cases in which a foreign company receiving passive income is the beneficial owner. According to a press release by the Ministry in April 2011, the Danish Tax and Custom Administration had by that time raised 31 cases. In 16 of the cases, the Administration had levied total withholding tax of DKK 19 billion. $^{26}$

Another example is the position that the Indian Central Board of Direct Taxation adopted with respect to the India-Mauritius double tax treaty of 24 August $1982 .{ }^{27}$ In 2000 , it issued a circular stating that treaty benefits should be allowed based on a tax residency certificate issued by the Mauritian Revenue Authority. ${ }^{28}$

In Union of India $v$ Azadi Bachao Andolan, ${ }^{29}$ the Supreme Court of India upheld the validity of the circular and observed that, in the absence of specific anti-abuse provisions in a tax treaty, the benefit of the tax treaty

\footnotetext{
${ }^{26}$ See Hans Severin Hansen "The Great Hypocrisy - the "Beneficial Owner" cases" Danish Journal for Taxes and Duties (Tidsskrift for Skatter og Afgifter) -TfS 2011, 537.

${ }^{27}$ Convention for Avoidance of Double Taxation and the Prevention of Fiscal Evasion with Respect to Taxes on Income and Capital Gains, India-Mauritius (24 August 1982, entered into force 6 December 1983).

${ }^{28}$ Circular No 789 of 2000.

${ }^{29}$ Union of India v Azadi Bachao Andolan (2003) 263 ITR 706 (SC)
} 
cannot be denied to persons qualifying as residents of the other contracting state. The court explained: ${ }^{30}$

The developing countries allow treaty shopping to encourage capital and technology inflows, which developed countries are keen to provide to them. The loss of tax revenues could be insignificant compared to the other non-tax benefits to their economy. Many of them do not appear to be too concerned unless the revenue losses are significant compared to the other tax and non-tax benefits from the treaty, or the treaty shopping leads to other tax abuses.

There are many principles in fiscal economy which, though at first blush might appear to be evil, are tolerated in a developing economy, in the interest of long-term development. Deficit financing, for example, is one; treaty shopping, in our view, is another. Despite the sound and fury of the respondents over the so-called "abuse" of "treaty shopping", perhaps, it may have been intended at the time when the [India-Mauritius double tax agreement] was entered into. Whether it should continue, and, if so, for how long, is a matter which is best left to the discretion of the executive as it is dependent upon several economic and political considerations. This court cannot judge the legality of treaty shopping merely because one section of thought considers it improper. A holistic view has to be taken to adjudge what is perhaps regarded in contemporary thinking as a necessary evil in a developing economy.

This observation implies that the object and purpose of limiting benefits of the India-Mauritius double tax treaty is insignificant in the light of national economic policy. Although Azadi Bachao Andolan did not concern beneficial ownership, court's reasoning has implications for the application of the beneficial ownership requirement in Indian double tax treaties.

The circular and the decision of Azadi Bachao Andolan has allowed residents of non-contracting states to obtain tax benefits by interposing companies in Mauritius. According to several estimates, 42 per cent of foreign direct investments in India are made from Mauritius, and

${ }^{30}$ Ibid, 753. 
India loses $\$ 100$ million to $\$ 500$ million of revenue per year. $^{31}$

Further, software and pharmaceutical companies have been able to avoid the United States tax on their foreign income by adopting an arrangement that includes schemes commonly referred to as the "double Irish" and "Dutch sandwich". Essentially, the arrangement involves channelling foreign income of subsidiaries in tax havens via affiliated companies located in Ireland and the Netherlands. For example, from 2007 to 2009, Google saved tax totalling $\$ 3.1$ billion. $^{32}$

Although the arrangement is an aggressive tax avoidance strategy, it does not constitute a conduit company strategy by itself. Thus, it is out of the scope of this thesis. However, with regard to Ireland, certain royalty payments are not subject to withholding tax, and the Netherlands does not impose withholding tax on royalties at all. This zero withholding tax rate policy has allowed Irish and Dutch companies to pass on royalties to the subsidiaries in tax havens virtually free of tax. Although the zero withholding tax rates on royalties in these countries may have been driven by their economic policies, it has caused them as well as other countries to lose huge sums of revenue.

31 "FIIs Play Havoc Every Time Government Mentions Mauritius" The Economic Times (online ed, New Delhi, 21 June 2011).

32 “"Dutch Sandwich' Saves Google Billions in Taxes” Bloomberg Businessweek (online ed, 22 October 2010). 
CHAPTER 2

CONFUSIONS OF THE LEGALISTIC APPROACH

2. Confusions of the legalistic approach ................. 35

2.1. Introduction ..................................................... 36

2.2. Interpretation of double tax conventions .............. 37

2.3. Beneficial ownership test in the OECD Model Convention......................................................... 40

2.4. Aiken Industries Inc $v$ Commissioner of Internal Revenue ................................................................ 41

2.5. Aiken Industries: the interpretation of the term "beneficial owner" ................................................ 44

2.6. N AG v Regional Tax Officer for Upper Austria .... 46

2.7. The $N A G$ case: the interpretation of the term "beneficial owner" ........................................... 48

2.8. "Beneficial owner": ordinary meaning ................ 48

2.9. The Re V SA case ................................................ 50

2.10. Re V SA: ordinary meaning of "beneficial ownership"

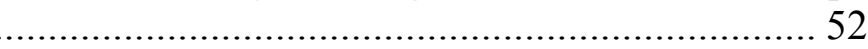

2.11. "Beneficial owner": legal meaning ....................... 54

2.12. "Beneficial ownership": English law meaning...... 56

2.13. Analogy between the ordinary and legal meaning of the term "beneficial owner".

2.14. To what extent can the beneficial ownership concept be incorporated in double tax conventions? .......... 60

2.15. The conventional legal view .............................. 61

2.16. Eisner v Macomber ........................................... 62

2.17. The Macomber case: interpretation of beneficial ownership 64

2.18. The "separate entity theory" and conduit companies

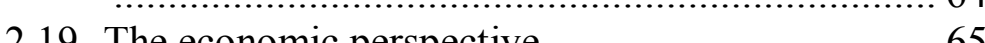

2.20. Aiken Industries: an economic approach............... 67

2.21. The $N A G$ case: an economic approach................ 67

2.22. Economic perspective: companies can never be entitled to treaty benefits ..................................... 68

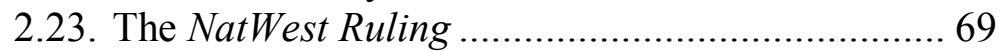

2.24. The NatWest Ruling: paradoxical perspectives..... 71

2.25. Ectopia: dislocation between the beneficial ownership test and conduit companies................ 73

2.26. Application of the beneficial ownership test to conduit companies by the OECD........................... 75

2.27. Why does the OECD assume that conduit companies are capable of being the beneficial owners of passive income? ............................................................... 75

2.28. Application of the beneficial ownership test to conduit companies by courts ............................... 77

2.29. Why do courts apply the beneficial ownership test to conduit companies? 
2.30. Surrogate tests 79

2.31. Conclusion. 80

\subsection{Introduction}

Double tax conventions are diplomatic agreements of a fiscal nature. They should be construed in a substantive economic sense, in order to ensure that treaty benefits are available only to residents of the contracting states. From a substantive economic point of view, companies are legal fictions that shareholders use in order to derive income. It follows that theoretically from an economic perspective, income tax should be imposed at the level of shareholders, not at the level of corporations. Contrary to this implication, the OECD has decided to recognise companies for treaty purposes. The OECD's decision seems pragmatic because it is hard to operate income tax treaties unless companies are recognised. This decision causes the OECD Model Convention to operate simultaneously in two contradictory manners. On one hand, the Model Convention operates in a substantive economic sense to ensure that its benefits are limited to residents of the contracting states. On the other, it recognises companies for tax purposes, which is impossible from the substantive economic point of view.

The contradictory manner of functioning of the OECD Model Convention cause problems in the interpretation and application of Articles 10, 11 and 12, which provide for a reduction in withholding tax on passive income. Residents of a non-contracting state can improperly obtain benefits of the reduction by interposing a company as the recipient of passive income in a contracting state. As discussed in section 1.7, such companies are commonly known as "conduit companies". Articles 10(2), 11(2), and 12(1) of the OECD Model Convention require the recipient 
of passive income to be the beneficial owner of that income.

Theoretically, conduit companies should never be entitled to treaty benefits because their shareholders, who enjoy passive income in an economic sense, are residents of a non-contracting state. However, the OECD's Conduit Companies Report and the official commentary on the Model Convention assume that at least in some situations conduit companies can be considered beneficial owners of passive income. The assumption is a logical impossibility that makes it difficult to interpret and apply the beneficial ownership concept.

This chapter examines in detail the point mentioned in chapter 1 , which is that it is inherently illogical to apply the beneficial ownership concept as a test to conduit company cases. To illustrate the point, it explains the application of the beneficial ownership concept in trust law and in the OECD Model Convention. It also discusses the legal and economic perspectives of the application of income tax law to corporations.

\subsection{Interpretation of double tax conventions}

Treaties should be construed liberally rather than in the strict legalistic manner by which domestic statutes are generally interpreted. ${ }^{33}$ As an international treaty, a double tax convention should also be subjected to liberal interpretation. $^{34}$ The interpretation of a double tax convention is governed by public international law and specifically by Article 31(1) of the Vienna Convention on

\footnotetext{
${ }^{33}$ See generally Fothergill v Monarch Airlines Ltd (1980) AC 251.

${ }^{34}$ Gladden Estate v Minister of National Revenue (1985) 1 CTC 163, 166.
} 
the Law of Treaties, ${ }^{35}$ which provides that treaties should be interpreted in the context of their object and purpose. ${ }^{36}$

Double tax conventions are bilateral agreements entered with the general economic objective of mitigating double taxation. To achieve this objective, the contracting states agree to restrict their substantive tax law reciprocally. That is, a double tax convention forms an independent mechanism to avoid double taxation only between its contracting states. ${ }^{37}$

A resident of a third state can improperly obtain benefits that a double tax agreement provides to residents of its contracting states, by interposing a person or a conduit entity in one of the contracting states. For this reason, another purpose of a double tax convention is to prevent its improper use by limiting its benefits to residents of its contracting states. The Swiss Federal Commission of Appeal in Tax Matters in $\operatorname{Re} V S A,{ }^{38}$ explained: ${ }^{39}$

... double taxation conventions ... are primarily intended to avoid international double taxation ...

\footnotetext{
${ }^{35}$ Vienna Convention on the Law of Treaties (23 May 1969, entered into force 27 January 1980), Art 31(1). Indofood International Finance Ltd v JP Morgan Chase Bank NA, London Branch [2006] EWCA Civ 158, at para 24. Re V SA (2001) 4 ITLR 191 (The Federal Commission of Appeal in Tax Matters, Switzerland), at 208. See Philip Baker Double Taxation Conventions and International Tax Law (2 ed, Sweet and Maxwell, London, 1994) at 21.

${ }^{36}$ The Vienna Convention, above n 35, art 31(1). It states: “A treaty shall be interpreted in good faith in accordance with the ordinary meaning to be given to the terms of the treaty in their context and in the light of its object and purpose."

${ }^{37}$ Klaus Vogel Double Taxation Conventions: a Commentary to the OECD-, UN-, US-Model Conventions for the Avoidance of Double Taxation of Income and Capital with particular reference to German Treaty Practice (Kluwer, Deventer, 1990) at 19. See David A Ward "Principles to be Applied in Interpreting Tax Treaties" (1977) 25 Canadian Tax Journal 263 at 265.

${ }^{38}$ Re V SA (2001) 4 ITLR 191 (The Federal Commission of Appeal in Tax Matters, Switzerland).

${ }^{39}$ Ibid, at 210.
} 
However, only international double taxation of residents of a contracting state are covered by these conventions ... double taxation conventions do not have as their object to permit persons who are not residents of a contracting state to benefit from the advantages of the convention ...

The context of the object and purpose of limiting the benefits requires double tax agreements to be interpreted in an economic sense. The Austrian Supreme Administrative Court in $N A G v$ Regional Tax Officer for Upper Austria ${ }^{40}$ expressed the same opinion. As will be discussed in section 2.7, the $N A G$ case concerned the Austria-Switzerland double tax treaty of 30 January $1974,{ }^{41}$ which did not have an anti-abuse clause. The court observed: ${ }^{42}$

If a double taxation convention contains provisions which bear on the economic aspects of tax questions and the attribution of assets, these provisions must be applied. The absence of such provisions in a convention - as in the case of this [double tax convention] - does not, however, justify the conclusion that the convention permits the use of nominee arrangements to obtain treaty benefits or the abuse of the forms and institutions of civil law. Such a conclusion would be incompatible with the goal and purpose of the convention, to assign taxing rights between the two states according to objective criteria. Where a treaty does not contain specific provisions on an economic approach and attribution of economic interests a state accordingly has the right to protect itself against an unjustified exploitation of the tax benefits provided for in the convention.

The observation confirms that because a double tax convention is an agreement between two countries, one of its objects and purposes is to limit its benefits to residents of the contracting states. For this reason, regardless of

${ }^{40}$ N AG v Regional Tax Officer for Upper Austria (2000) 2 ITLR 884 (The Supreme Administrative Court, Austria).

${ }^{41}$ Convention for Avoidance of Double Taxation and the Prevention of Fiscal Evasion with Respect to Taxes on Income and on Capital Gains, Switzerland-Austria (30 January 1974, entered into force 4 December 1974).

${ }^{42} N$ AG v Regional Tax Officer for Upper Austria, above n 40, at 900 (emphasis added). 
whether its provisions contain specific anti-abuse clauses, a treaty should be interpreted in a substantive economic sense in order to prevent residents of non-contracting states from improperly obtaining tax benefits it provides.

As discussed earlier, this thesis concerns provisions that deal with the double taxation of passive income, which are generally based on Articles 10,11 and 12 of the OECD Model Convention. They mitigate double taxation by limiting the right to tax of the state where passive income originates, which will be referred to as the source state. In order to ensure that the benefit of the withholding tax reduction is limited to residents of the contracting states, Articles 10, 11 and 12 of the OECD Model Convention require the recipient to be the "beneficial owner" of income. In the context of the object and purpose of double tax agreements, the term "beneficial owner" should logically connote that the immediate recipient must be the owner in a substantive economic sense. The official commentary on Articles 10,11 and 12 of the OECD Model Convention supports this argument.

\subsection{Beneficial ownership test in the OECD Model Convention}

In 1977, the OECD Model Convention adopted the notion of beneficial ownership as a test to determine whether a party is entitled to treaty benefits. The official commentary on Articles 10, 11, and 12 of the OECD Model Convention states that the object of introducing the beneficial ownership requirement was "to clarify":

1. the meaning of the words "paid....to a resident of a contracting state" in Articles $10(1)^{43}$ and 11(1); ${ }^{44}$ and,

43 OECD Committee on Fiscal Affairs "Commentary on Article 10 concerning the Taxation of Dividends" (OECD, Paris, 2010) in OECD 
2. how article 12 applies in relation to payments made to intermediaries. ${ }^{45}$

According to the official commentary, the requirement: ${ }^{46}$

makes it plain that the state of source is not obliged to give up taxing rights over passive income merely because that income was immediately received by a resident of the other contracting state.

This statement is essentially a reiteration of the policy of limiting benefits of the convention to residents of contracting states. The use of phrases "to clarify" and "makes it plain" shows that the term "beneficial owner" simply emphasises the policy. Because the purpose is entrenched in double tax treaties, it would have produced the same result in the absence of the term "beneficial owner". ${ }^{47}$ Aiken Industries Inc v Commissioner of Internal Revenue $^{48}$ helps to illustrate this point. That case was decided before the term "beneficial owner" was introduced to the OECD Model Convention.

\subsection{Aiken Industries Inc v Commissioner of Internal Revenue}

Ecuadorian Corp Ltd, a resident of the Bahamas, which will be referred to as Ecuadorian Ltd, wholly owned Aiken

Committee on Fiscal Affairs Model Tax Convention on Income and on Capital (OECD, Paris, 2010) 187 at para 12.

44 OECD Committee on Fiscal Affairs "Commentary on Article 11 concerning the Taxation of Interest" (OECD, Paris, 2010) in OECD Committee on Fiscal Affairs Model Tax Convention on Income and on Capital (OECD, Paris, 2010) 211 at para 9.

45 OECD Committee on Fiscal Affairs "Commentary on Article 12 concerning the Taxation of Royalties" (OECD, Paris, 2010) in OECD Committee on Fiscal Affairs Model Tax Convention on Income and on Capital (OECD, Paris, 2010) 220 at para 4.

${ }^{46}$ Commentary on Article 10, above n 43 at para 12. Commentary on Article 11, above n 44 at para 9. Commentary on Article 12, above n 45 at para 4 (emphasis added).

${ }^{47}$ See also Vogel above n 37, at 459.

${ }^{48}$ Aiken Industries Inc v Commissioner of Internal Revenue 56 TC 925 (1971). 
Industries, a United States resident corporation. Aiken Industries took over the ownership as well as the relevant rights and obligations of Mechanical Products Inc, another United States resident corporation, which will be referred to as Mechanical Inc. Mechanical Inc was initially involved in the disputed transaction. Aiken Industries became the party in this action as a consequence of its takeover of Mechanical Inc. Ecuadorian Ltd also held all the shares of $\mathrm{CCN}$, a resident of Ecuador, which, in turn, wholly owned Industrias, a Honduran corporation.

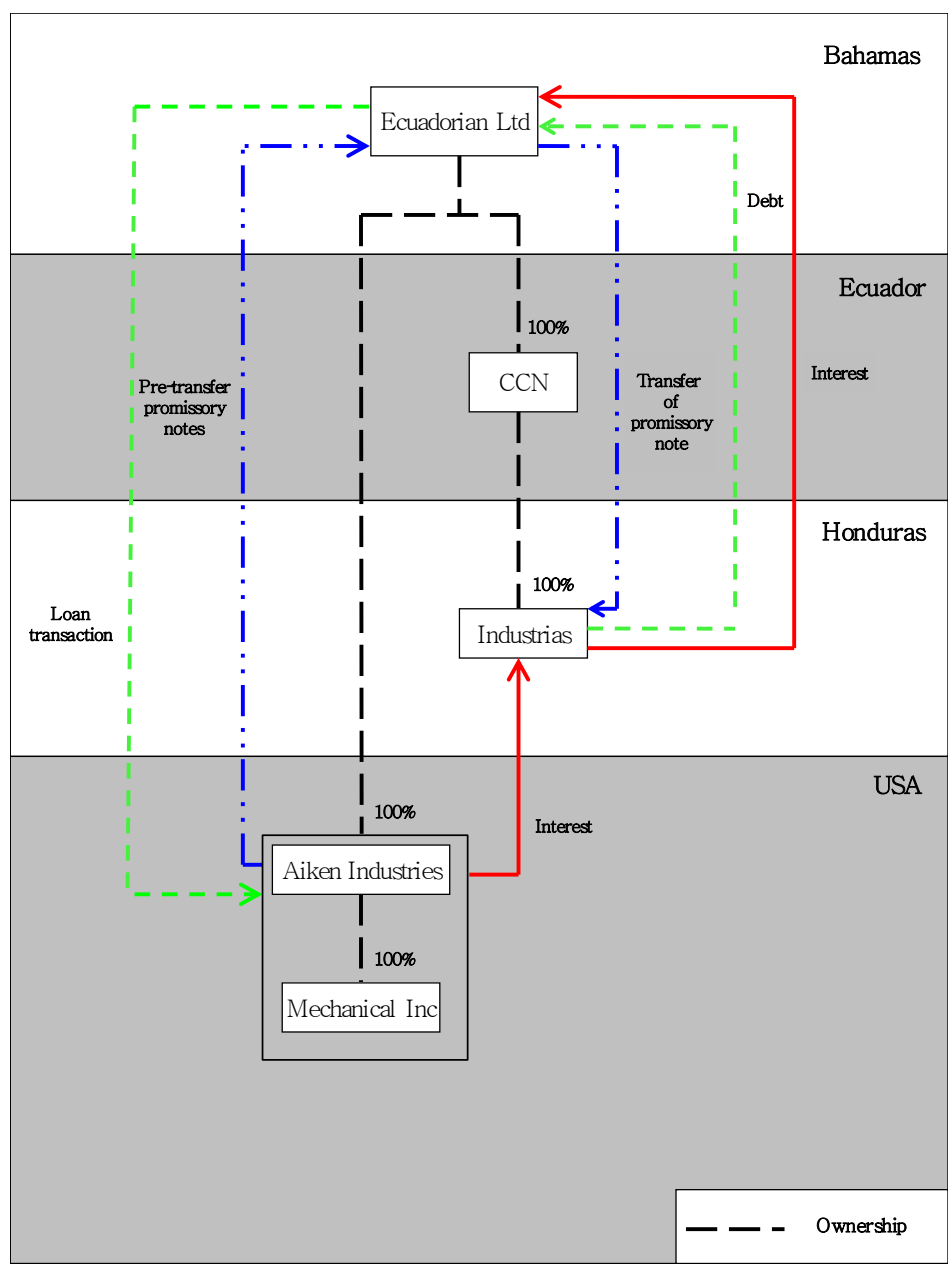

Figure 2.1: Aiken Industries

Ecuadorian Ltd made a loan to Mechanical Inc on a promissory note. Since there was no double tax treaty between the United States and the Bahamas, Mechanical Inc would have to deduct United States domestic 
withholding tax on interest payments to Ecuadorian Ltd.

Ecuadorian Ltd interposed Industrias in the transaction and transferred Mechanical Inc's promissory note to Industrias in consideration of a debt outstanding. The effect of the transaction was as if back-to-back loans were made from Ecuadorian Ltd to Industrias and subsequently from Industrias to Mechanical Inc.

The transaction was designed to take advantage of the United States withholding tax exemption under Article IX of the United States-Honduras double tax treaty of 26 June 1956. ${ }^{49}$ Accordingly, Mechanical Inc withheld no tax on the interest payments. The Commissioner of Internal Revenue determined deficiencies in withholding tax.

The Commissioner alleged before the United States Tax Court that the existence of Industrias as a corporation should be disregarded for tax purposes because Ecuadorian Ltd was the true owner and the recipient of the interest. Aiken Industries responded that Industrias complied with the definition of a corporation under Article II of the treaty, ${ }^{50}$ and therefore could not be disregarded. It contended that Industrias received the income as a "Honduran enterprise", and therefore the interest payments should be exempt from withholding tax under the treaty.

${ }^{49}$ Convention for Avoidance of Double Taxation and the Prevention of Fiscal Evasion with Respect to Taxes on Income, the United States-Honduras (25 June 1956, entered into force 6 February 1957). The convention was terminated on 31 December 1966.

50 The United States-Honduras double tax treaty of 25 June 1959, above n 49, art II. Art II(g) stated: The term "Honduran enterprise" means an industrial or commercial or agricultural enterprise or undertaking carried on by a resident of Honduras (including an individual in his individual capacity or as a member of a partnership) or a fiduciary of Honduras or by a Honduran corporation or other entity; the term "Honduran corporation or other entity" means a corporation or other entity formed or organized in Honduras or under the laws of Honduras. 
The court had to decide whether the treaty was applicable to the facts and circumstances of the case in order to exempt Mechanical Inc from the requirement to deduct withholding tax from its interest payment to Industrias. The court held that the interest payments were not exempt from the United States withholding tax.

\subsection{Aiken Industries: the interpretation of the term "beneficial owner"}

When the United States Tax Court decided the Aiken

Industries case neither Article IX of the United StateHonduras double tax treaty nor Article 11 of the OECD Model Convention used the term "beneficial owner". The relevant part of Article IX of the United State-Honduras double tax treaty stated: ${ }^{51}$

Interest on ... notes ... from sources within one of the contracting States received by a resident, corporation or other entity of the other contracting State not having a permanent establishment ... shall be exempt from tax by such former State.

The court interpreted the words "received by" in Article IX according to the language and context of the treaty, and observed: ${ }^{52}$

As [utilised] in the context of article IX, we interpret the terms "received by" to mean interest received by a corporation of either of the contracting States as its own and not with the obligation to transmit it to another. The words "received by" refer not merely to the obtaining of physical possession on a temporary basis of funds representing interest payments from a corporation of a contracting State, but contemplate complete dominion and control over the funds.

The words "received by a resident ... of the other contracting State" in the United States-Honduras double tax treaty and "paid ... to a resident of a Contract State" in the OECD Model Convention point to the same person,

${ }^{51}$ The United States-Honduras double tax treaty of 25 June 1959, above n 50, art IX.

${ }^{52}$ Ibid, at 933 (emphasis added). 
who is the immediate recipient of the passive income. ${ }^{53}$ In this context, the foregoing interpretation becomes relevant to the approach that, according to the official commentary, the term "beneficial owner" was introduced to clarify. ${ }^{54}$ The foregoing observation of the court, in fact, illuminates the approach. The court essentially followed the object and purpose of the treaty to limit its benefits to the contracting states.

Because the court used the phrase "complete dominion and control", the observation implies that in order to qualify for the reduction of withholding tax, the recipient of passive income should be a person who owns passive income in a substantive economic sense. Following the object and purpose of limiting treaty benefit, it found: $:^{55}$

Industrias was merely a conduit for the passage of interest payments from [Mechanical Inc] to [Ecuadorian Ltd]. Industrias had no actual beneficial interest in the interest payments it received, and in substance, [Mechanical Inc] was paying the interest to [Ecuadorian Ltd.] which "received" the interest within the meaning of article IX.

The court used the term "beneficial interest", which is simply a linguistic variation of the concept of beneficial ownership. Thus, the observation shows that the court read the beneficial ownership requirement into the provision. The court's use of the term "beneficial interest" suggests substantive economic ownership.

The Austrian Supreme Administrative Court in $N A G v$ Regional Tax Officer for Upper Austria ${ }^{56}$ adopted a

${ }^{53}$ See also Stef van Weeghel The Improper Use of Tax Treaties: with Particular Reference to the Netherlands and the United States (Kluwer, London, 1998) at 89.

${ }^{54}$ The commentary on Articles 10, 11 and 12 of the OECD Model Convention, above $\mathrm{n} 46$.

${ }^{55}$ Aiken Industries Inc $v$ Commissioner of Internal Revenue, above $\mathrm{n}$ 48, at 934 (emphasis added).

${ }^{56}$ N AG v Regional Tax Officer for Upper Austria (2000) 2 ITLR 884 (The Supreme Administrative Court, Austria). 
similar approach. The $N A G$ case was decided after the term "beneficial owner" was introduced to the OECD Model Convention.

\subsection{N AG v Regional Tax Officer for Upper Austria}

$\mathrm{N}$ AG, a Swiss corporation, was one of the shareholders of W Ltd, an Austrian company. W Ltd paid a dividend to N AG and deducted Austrian withholding tax from the payment. N AG applied to the Austrian tax authorities for a refund of withholding tax under Article 28(2) of the Austria-Switzerland double tax treaty of 30 January 1974. ${ }^{57}$ The Austrian tax authority refused the refund to $\mathrm{N}$ AG. The tax authority had evidence that the shareholders of N AG, Dr T and Dr L, who were Swiss residents, were merely nominees for the ultimate owners, who were not resident in Switzerland. Thus, according to the tax authority $\mathrm{N}$ AG was a conduit company. N AG produced a resident certificate from the Swiss Tax Administration that certified that $\mathrm{N}$ AG did not pass on the treaty-favoured profits to others who were not entitled to the benefit of the Austria-Switzerland double tax treaty. However, the Austrian tax authority did not regard the certificate as conclusive.

${ }^{57}$ The Austria-Switzerland double tax treaty, above n 41, art 28(2). It states: "... the tax withheld by way of deduction (at the source) shall be refunded upon request, providing this Agreement restricts the levying of such tax ..." 


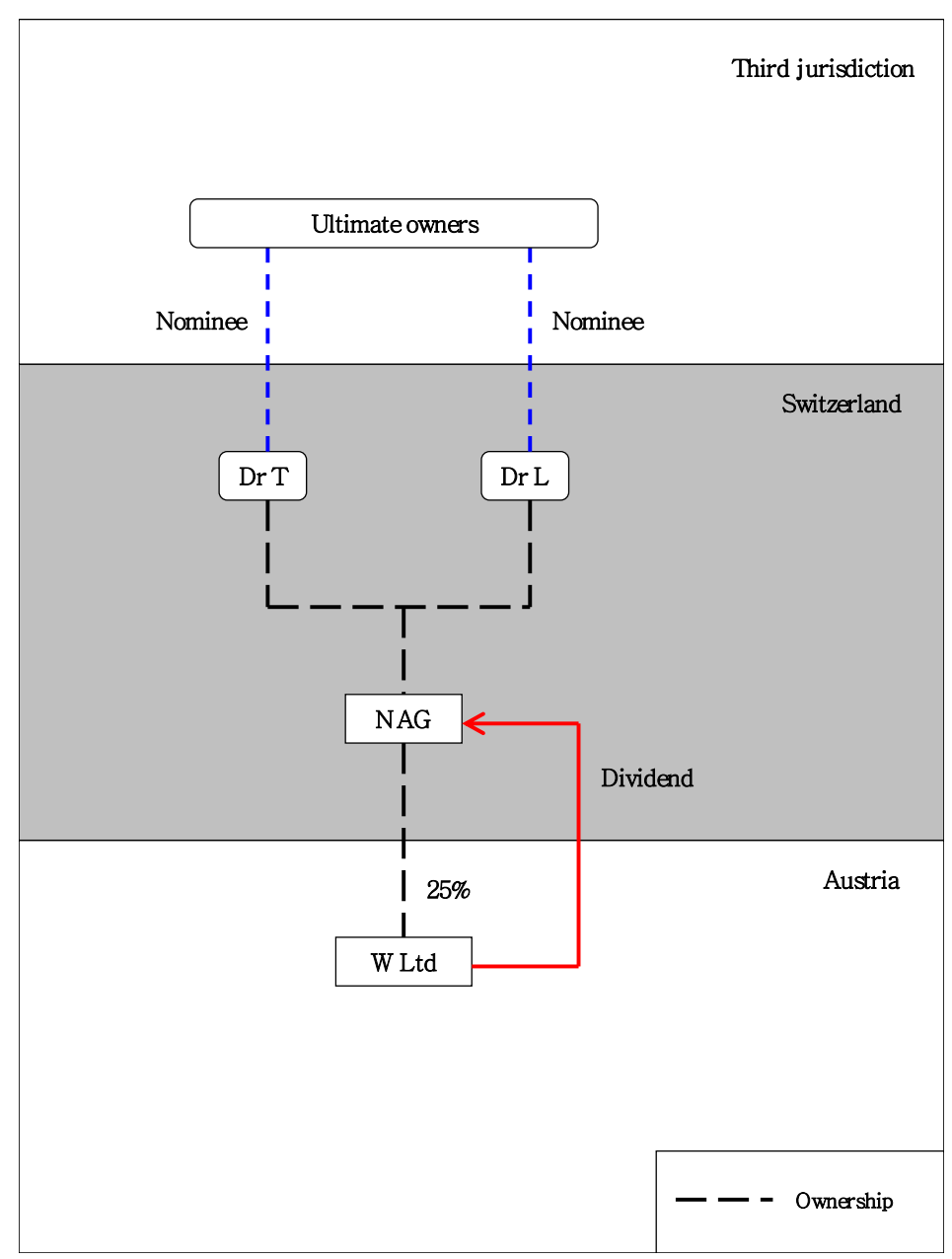

Figure 2.2: N AG v Regional Tax Office for Upper Austria

The issue before the Austrian Supreme Administrative Court was whether the Austrian tax authority was entitled to investigate whether $\mathrm{N}$ AG had been interposed only to extract benefits under the treaty because the "real economic owners" ${ }^{, 58}$ of the income would not have been able to claim tax relief. The court decided in favour of the tax authority.

${ }^{58}$ N AG v Regional Tax Officer for Upper Austria, above n 56, at 900. 


\subsection{The $N A G$ case: the interpretation of the term "beneficial owner"}

Although Article 28(2) of the Austria-Switzerland double tax treaty of 30 January $1974^{59}$ did not use the word "beneficial owner", the court observed: ${ }^{60}$

... the pre-requisite for the repayment of withholding tax was inter alia that the recipient of the dividends should be the beneficial owner of the investments which gave rise to the dividends.

It is clear that as with the United States Tax Court in Aiken Industries, ${ }^{61}$ the Austrian Supreme Administrative Court read the beneficial ownership requirement into a provision that did not use the term "beneficial owner".

In the light of the court's observation quoted in section 2.2, it is obvious that the court considered Article 28(2) to be a "provision on an economic approach and attribution of economic interests". ${ }^{62}$ That is, it accorded an economic effect to the term "beneficial owner".

Aiken Industries and the $N A G$ case confirm that in the language and context of double tax treaties in general, and the OECD Model Convention in particular, the term "beneficial owner" means a person who has the substantive economic ownership of passive income.

\section{8. "Beneficial owner": ordinary meaning}

The documents concerning the work of the OECD Committee on Fiscal Affairs with respect to Articles 10,

${ }^{59}$ Convention for Avoidance of Double Taxation and the Prevention of Fiscal Evasion with Respect to Taxes on Income and on Capital Gains, Switzerland-Austria (30 January 1974, entered into force 4 December 1974), art 28(2). It states: “... the tax withheld by way of deduction (at the source) shall be refunded upon request, providing this Agreement restricts the levying of such tax ..."

${ }^{60} N$ AG v Regional Tax Officer for Upper Austria, above n 57, at 899 (emphasis added).

${ }^{61}$ Aiken Industries Inc $v$ Commissioner of Internal Revenue, above $\mathrm{n}$ 48 , at 934 (emphasis added).

${ }^{62}$ N AG v Regional Tax Officer for Upper Austria, above n 56, at 900 (emphasis added). 
11 and 12 before the insertion of the term "beneficial owner" show that according to the United Kingdom delegation: ${ }^{63}$

... Articles 10, 11 and 12 were defective in that they would apply to dividends, interest and royalties paid to an agent or a nominee with a legal right to the income.

A remedy that the delegation suggested was that the Articles should be applied only to passive income paid to the "beneficial owner". Delegates for Switzerland and the United States supported the suggestion. The committee was of the opinion that it was evident that relief in a source state was available only if the recipient of passive income was "actually resident in the other contracting state" Nevertheless, it decided to insert the term "beneficial owner" in Articles 10,11 and 12.

In the light of the United Kingdom delegation's concern, the committee's decision suggests that it acknowledged that sometimes courts tend to interpret tax treaties in a strict legalistic manner. A legalistic interpretation would lead them to base their decisions on formal ownership. However, because this approach would contradict the object and purpose of double tax

${ }^{63}$ OECD Committee on Fiscal Affairs "Note on the Discussion of the First Report of Working Party No 27 of the Fiscal Committee on Interest and Royalties during the 31 st Session of the Fiscal Committee held from $10^{\text {th }}$ to $13^{\text {th }}$ June, 1969" DAF/FC/69.10, 4 July 1969 , at 6 $<$ www.taxtreatieshistory.org $>$. OECD Committee on Fiscal Affairs "Preliminary Report on Suggested Amendments to Articles 11 and 12 of the Draft Convention, relating to Interest and Royalties Respectively" FC/WP27 (68) 1, 30 December 1968, at 14 $<$ www.taxtreatieshistory.org $>$.

64 OECD Committee on Fiscal Affairs "Preliminary Report on Suggested Amendments to Articles 11 and 12 of the Draft Convention, relating to Interest and Royalties Respectively" FC/WP27 (68) 1, 30 December 1968, at 14 <www.taxtreatieshistory.org>.

${ }^{65}$ Ibid. 
conventions, the committee decided to insert an expression that calls for an economic approach.

Article $31(1)$ of the Vienna Convention states: ${ }^{66}$

A treaty shall be interpreted in good faith in accordance with the ordinary meaning to be given to the terms of the treaty in their context and in the light of its object and purpose.

A possible reason why the Committee adopted the term "beneficial owner" is that the ordinary meaning of the word "beneficial" accurately captures the economic approach. In the term "beneficial owner" the use of "beneficial" means that the owner is entitled to enjoy the property. Words such as "real", "ultimate" or "true" might have been alternatives; however, they do not necessarily express their economic consequences.

In the Re $V S A$ case,${ }^{67}$ the Swiss Federal Commission of Appeal in Tax Matters also referred to the ordinary meaning of the terms "bénéficiare effectif" and "bénéficiare" and interpreted them in an economic sense. When translated from French they mean "effective beneficiary" or "beneficial owner", and "beneficiary" respectively.

\subsection{The $\operatorname{Re} V$ SA case}

Two British companies incorporated V SA in Luxembourg. V SA acquired all the capital in I SA, a Swiss company, with the help of a loan from the British companies. I SA made separate dividend payments to V SA in the first and second year of its incorporation. It deducted Swiss withholding tax on the payments.

66 Vienna Convention on the Law of Treaties (23 May 1969, entered into force 27 January 1980), art 31(1) (emphasis added).

${ }^{67}$ Re V SA 4 ITLR 191 (The Federal Commission of Appeal in Tax Matters, Switzerland). 


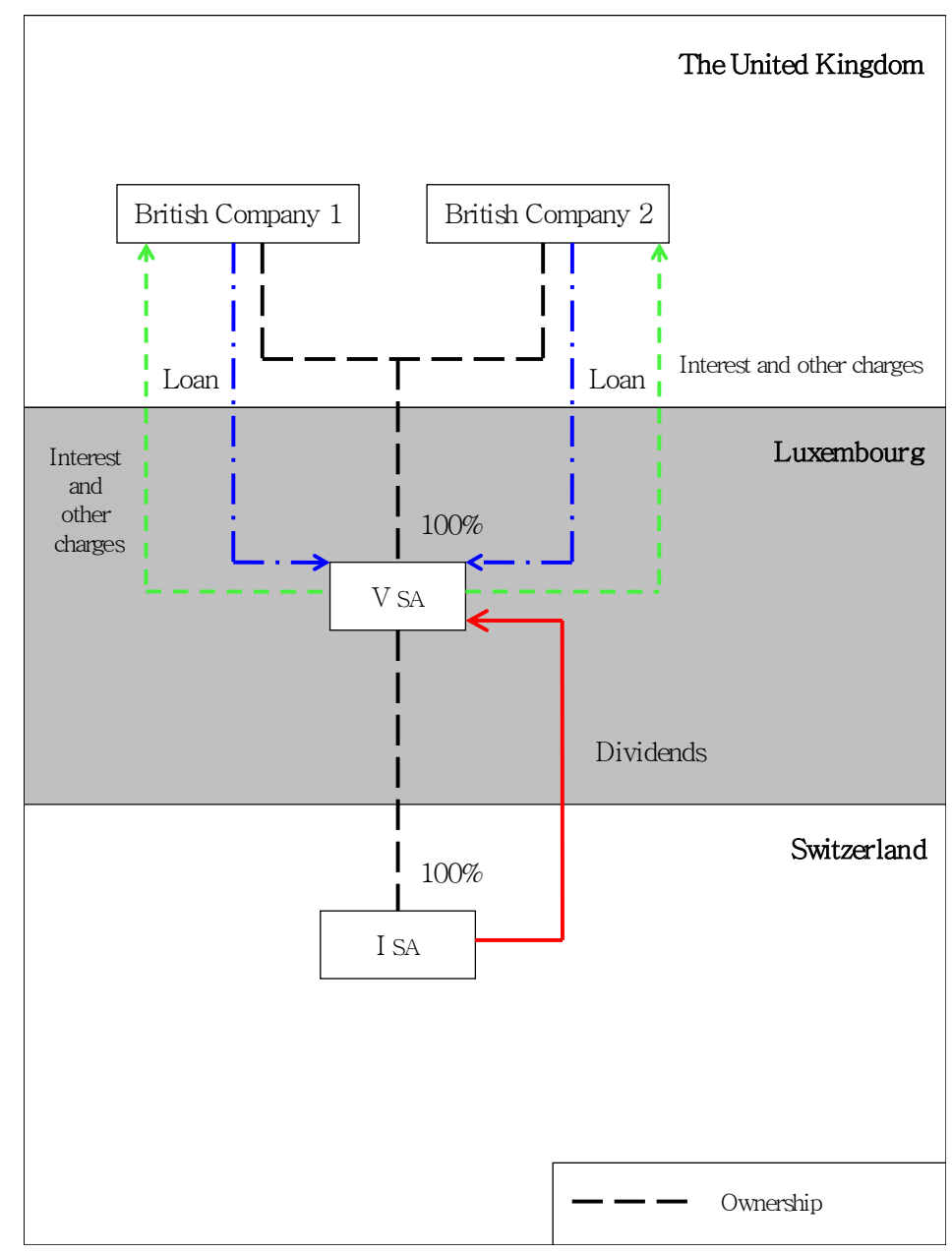

Figure 2.3: $\operatorname{Re} V S A$

Article 10(2)(a) of the Switzerland-Luxembourg double tax treaty of 21 January 1993 states: ${ }^{68}$

a) ... dividends may also be taxed in the Contracting State of which the company paying the dividends is a resident and according to the laws of that State, but if the recipient is the effective beneficiary of the dividends the tax so charged shall not exceed:

i) 5 percent of the gross amount of the dividends if the effective beneficiary is a company (other than a partnership) which holds directly at least 25 percent of the capital of the company paying the dividends;

Whereas, Article 10(2)(b) states: ${ }^{69}$

${ }^{68}$ Convention for Avoidance of Double Taxation and the Prevention of Fiscal Evasion with Respect to Taxes on Income, SwitzerlandLuxembourg (21 January 1993, entered into force 19 February 1994), art 10(2)(a) (emphasis added).

${ }^{69}$ Ibid, art 10(2)(b) (emphasis added). 
Notwithstanding the provisions of [clause] (i) of subparagraph a), the dividends are exempt in the Contracting State of which the company paying the dividends is a resident, if the beneficiary is a company (other than a partnership) which is a resident of the other Contracting State and which holds, directly for an uninterrupted period of two years preceding the date of payment of such dividends, at least 25 percent of the capital of the company paying the dividends ....

Accordingly, V SA applied to the Swiss Tax Administration for partial and full reimbursements of withholding tax on the first and second dividend payments respectively.

On the demand of the Swiss Tax Administration, V SA submitted its statutory documents and annual accounts only for the year it received the first dividend payment. It did not reply to the question of whether it received the benefit of dividend payments. The administration denied refunds. The Federal Commission of Appeal in Tax Matters confirmed the administration's decision.

\subsection{0. $R e \quad V \quad S A$ : ordinary meaning of "beneficial ownership"}

The word "effective" did not accompany "beneficiary" in sub-paragraph (b), as it did in sub-paragraph (a). For this reason, the Swiss Federal Commission determined "whether the term "beneficiary" must be interpreted in the same sense as "effective beneficiary [beneficial owner]" or whether it refers exclusively to the direct formal shareholder." ${ }^{, 70}$ Referring to Article 31 of the Vienna Convention, the commission observed: ${ }^{71}$

Double taxation conventions must first be interpreted in accordance with the ordinary meaning given to the terms employed ...

A beneficiary is the person 'who receives a benefit, an advantage, etc' ... The beneficiary is thus the person who can actually benefit from a payment, and not one who receives it subject to an obligation to transfer it to a

\footnotetext{
${ }^{70} \operatorname{Re} V S A$, above n 67, at 208.

${ }^{71}$ Ibid, at 209.
} 
third person. Thus, a company which transferred to a third person dividends received without being able actually to dispose of them cannot be considered as the 'beneficiary'. The notion of 'beneficiary' envisages, therefore, according to the ordinary meaning to be attributed to this term, one who effectively receives a payment and can dispose of it. This definition overlaps with that of the 'effective beneficiary [beneficial owner]' which envisages the person who profits economically from income, and does not apply to conduit companies placed as intermediaries between the payer of income and the person who ultimately receives it ...

... the requirement of an effective beneficiary is implicit in double taxation conventions and does not require an express reference ...

$\ldots$ it follows from the sense of the word beneficiary that one cannot stop at the purely formal shareholder of a company, but rather it is necessary to research who is the person who can in reality and effectively benefit from the payment of income.

The Swiss Federal Commission noted that V SA provided incomplete information. V SA's annual accounts showed that it paid the entire income it received as dividends from I SA by way of interest and other charges to the British companies. The commission also pointed out that V SA's only significant asset was its holding in I SA. Considering these facts in the light of the ordinary meaning of the term "beneficiary", the commission found that V SA was "manifestly only a conduit company", that could not be considered as the beneficiary of the dividends.

The commission's approach corresponds to the line of the argument in section 2.8. The ordinary meaning of the terms "bénéficiare" and "bénéficiare effectif" led the commission to interpret them in an economic sense. Because the term "bénéficiare effectif" is the French equivalent of the term "beneficial owner", the observation also shows that the ordinary meaning of the term “beneficial owner" reflects economic consequences.

${ }^{72} \operatorname{Re} V S A$, above n 67, at 210. 
As with Aiken Industries ${ }^{73}$ and the $N A G$ case, ${ }^{74}$ the commission considered the beneficial ownership requirement inherent in double tax treaties. In the context of the ordinary meaning of the terms "effective beneficiary" and "beneficial owner", the role played by words "effective" and "beneficial" are comparable. As with the OECD Committee on Fiscal Affairs, the negotiators of the Swiss-Luxembourg double tax treaty used "effective" to show that the immediate recipient should own passive income in a substantive economic sense. This may be the reason for using the word "effective" with "beneficiary" in sub-paragraph (a) so that the word "beneficial" could be read in the same light.

\subsection{1. "Beneficial owner": legal meaning}

The discipline of trust in English law also uses the concept of beneficial ownership. "Beneficial owner" is a term of art under English law. ${ }^{75}$ The concept of beneficial ownership originated in equity, a branch of English law separate from common law. Equity uses the concept of beneficial owner in the context of the trust. Whereas common law adopts the position that ownership cannot be divided, ${ }^{76}$ equity allows the division of ownership into legal ownership of the trustee and equitable or beneficial ownership of the beneficiary. Other common law countries follow English law and use the term "beneficial owner" in

${ }^{73}$ Aiken Industries Inc v Commissioner of Internal Revenue 56 TC 925 (1971).

${ }^{74}$ N AG v Regional Tax Officer for Upper Austria (2000) 2 ITLR 884 (The Supreme Administrative Court, Austria).

${ }^{75}$ Ayrest (Inspector of Taxes) $v C \& K$ (Construction) Ltd [1975] 2 All ER 537 at 540. See Philip Baker Double Taxation Conventions and International Tax Law (2 ed, Sweet and Maxwell, London, 1994) at 229.

${ }^{76}$ See John F Avery Jones and others "The Origins of Concepts and Expressions Used in the OECD Model and their Adoption by States" (2006) 60 Bulletin for International Taxation 220 at 246. 
the same sense in their domestic law. The English law meaning strongly influences the meaning of the concept in the OECD Model Convention.

Because most of the civil law countries ${ }^{77}$ do not use the term beneficial owner in their domestic tax law, the debate over the meaning of the term in the OECD Model convention essentially revolves around two questions. First, whether contracting states should refer to their domestic law under Article 3(2) of the OECD Model Convention for interpreting the term "beneficial owner" or whether the context of Articles 10, 11, 12 of the OECD Model Convention require beneficial ownership to be interpreted as a concept of international tax language, independent of domestic tax law. Second, if the concept of beneficial ownership is not seen as a reference to domestic law, how then should it be interpreted ${ }^{78}$

These questions, however, are not significant because the English trust law meaning of the term corresponds to its ordinary meaning in the context of double tax treaties. The following section discusses the beneficial ownership concept in English law.

${ }^{77}$ Belgium and the Netherlands use terms equivalent to beneficial owner. In the Netherlands, Article 1(1) of the Dividend Tax Act of 1969 uses the term "uiteindelijik gerechtigde", which means ultimately entitled. Art 198(1)(11) of the Belgian Income Tax Code use terms "uiteindelijik gerechtigde" or "bénéficiare effectif". See Hans Pijl "The Definition of "Beneficial Ownership" under Dutch Law" (2000) 54 Bulletin for International Taxation 256 at 258. See Wim Eynatten and others "The Concept of 'Beneficial Ownership' under Belgian Tax Law: Legal Interpretation is Maintained" (2003) 31 Intertax 523 at 524 .

${ }^{78}$ Klaus Vogel The OECD Model Convention, 1998 and Beyond: the Concept of Beneficial Ownership in Tax Treaties: Proceedings of a Seminar held in London in 1998 during the 52nd Congress of the International Fiscal Association (Kluwer Law International, London, 2000). 


\subsection{2. "Beneficial ownership": English law meaning}

English law uses the concept of beneficial ownership primarily to differentiate between the ownership rights of trustees and ownership rights of beneficiaries over trust property. In a trust, legal ownership is vested in trustees and beneficial ownership is typically vested in beneficiaries. Although the trustees as "legal owners" administer the trust property, they hold it for the benefit of the beneficiaries. Only the beneficiaries as "beneficial owners" have the right to appropriate the benefits of the subject matter of the trust. ${ }^{79}$ The point is that beneficial ownership can be distinguished from legal ownership mainly on the basis of the right to enjoy the benefits of a property.

English law also recognises the concept of beneficial ownership in tax and other legislation. When a tax provision depends on the nature of income, a taxpayer may find it advantageous to interpose a trust between himself and the source of the income merely to change the nature of the income.

Trust law distinguishes between income distributed to beneficiaries in the year it was derived by trustees and a distribution of trustees' income accumulated from past year. In the former case, income retains its nature in beneficiaries' hands, whereas in the latter, trust law considers income to be capital in the hands of beneficiaries. ${ }^{80}$ A taxpayer may take advantage of this trust law principle by allowing income to accumulate in a trust of which he is a beneficiary. Consequently, when the

\footnotetext{
${ }^{79}$ Keech $v$ Sandford (1726) EWHC Ch J76.

${ }^{80}$ Irvine v Houston (1802) Paton sc App 521. Paris v Paris (1804) 10 Ves 185. Witts $v$ Steere (1807) 13 Ves 363.
} 
trust distributes the past-accumulated income to the taxpayer, he receives it as a capital distribution.

In contrast, the tax law in United Kingdom does not make such a distinction. For tax purposes, courts have refused to treat the distribution of past-accumulated income to beneficiaries as capital, on the basis that the accumulation of income within a trust does not change anything as far as the underlying beneficial ownership in concerned. ${ }^{81}$ It, therefore, could be inferred that a beneficiary is usually the beneficial owner of the underlying income. $^{82}$

Tax statutes have used the term beneficial owner outside the field of trusts. ${ }^{83}$ Courts have applied these statutes to many cases; for example, in the liquidation of companies, ${ }^{84}$ in a case of a purchaser under a contract that is subjected to a condition precedent, ${ }^{85}$ and in the case of an owner who granted put and call options. ${ }^{86}$ Even though these cases did not involve trusts, judges drew analogies between the circumstances in these cases and trusts. For instance, in Ayerst (Inspector of Taxes) $v C \& K$ (Construction) $L t d,{ }^{87}$ the issue was whether the legal title to a company's property that remains in the company after the commencement of its winding-up still carries with it

${ }^{81}$ Baker $v$ Archer-Shee (1927) AC 844. Commissioner of Internal Revenue v Nevius 76 F2d 109 (2d Cir 1935).

${ }^{82}$ But see Kenneth A Williams $v$ The Queen (2005) DTC 1228 (Tax Court of Canada, Canada) and Gartside $v$ Inland Revenue Commissioners (1968) AC 553. The right or interest of a beneficiary in a discretionary trust does not amount to beneficial ownership.

${ }^{83}$ For example, the Finance Act 1954 (UK), s 17, the Finance Act of 1973 (UK), s 28(2), and, the Income and Corporation Taxes Act 1970 (UK), s 258.

${ }^{84}$ Ayerst (Inspector of Taxes) $v C \& K$ (Construction) Ltd, above n 75.

${ }^{85}$ Wood Preservation Ltd v Prior (Inspector of Taxes) [1969] All ER 364.

${ }^{86}$ J Sainsbury Plc v O'Connor (Inspector of Taxes) (1991) STC 318.

${ }^{87}$ Ayerst (Inspector of Taxes) $v C \& K$ (Construction) Ltd, above $\mathrm{n} 75$. 
any beneficial interest. Lord Diplock compared the rights of the company that was in the process of winding-up to the rights of a trustee and observed: ${ }^{88}$

... the concept of legal ownership of property, which did not carry with it the right of the owner to enjoy the fruits of it or dispose of it for his own benefit, owed its origin to the Court of Chancery. The archetype is the trust. The 'legal ownership' of the trust property is in the trustee, but he holds it not for his own benefit but for the benefit of the cestui que trustent or beneficiaries. On the creation of a trust in the strict sense as it was developed by equity the full ownership in the trust property was split into two constituent elements, which became vested in different persons: the 'legal ownership' in the trustee, and what came to be called the 'beneficial ownership' in the cestui que trust.

Similarly, in J Sainsbury Plc v O'Connor (Inspector of Taxes), ${ }^{89}$ the issue was whether Sainsbury was the beneficial owner of the shares over which Sainsbury had granted a put and call option to its partner in a joint venture. Lord Justice Nourse described beneficial ownership as: $:^{90}$

... ownership for your own benefit as opposed to ownership as trustee for another. It exists either where there is no division of legal and beneficial ownership or where legal ownership is vested in one person and beneficial ownership or, which is the same thing, the equitable interest in the property in another.

Lord Justice Nourse also defined beneficial ownership in the context of a trust. This observation further shows that in the context of trust law, courts have often used the term "equitable owner" in conjunction with beneficial owner. ${ }^{91}$

Two points emerge from the discussion so far. First, the beneficial ownership concept in domestic tax law is mainly related to questions of the difference between legal

${ }^{88}$ Ayerst (Inspector of Taxes) $v C \& K$ (Construction) Ltd, above $\mathrm{n} 75$, at 541 .

${ }^{89}$ J Sainsbury Plc v O'Connor (Inspector of Taxes), above n 86.

${ }^{90}$ Ibid, at 330.

${ }^{91}$ See also Wood Preservation Ltd v Prior (Inspector of Taxes) [1969] All ER 364 at 368. 
and equitable ownership in the context of a trust. ${ }^{92}$ Second, the main difference between a legal owner and a beneficial owner is that the legal owner is one who looks after the asset legally and the beneficial owner is one who has the substantive right to enjoy the asset and the income from it.

\subsection{Analogy between the ordinary and legal meaning of the term "beneficial owner"}

The discussion in section 2.12 shows that as with its ordinary meaning, the term "beneficial owner" in English law means a person able to enjoy a property for his or her own benefit. Applying the English law meaning to the term in the OECD Model Convention would lead to the same conclusion as the ordinary meaning. Further, because the OECD working party that introduced the term to the Model Convention included the United Kingdom and other common law jurisdictions, it is hard to imagine that other members were unaware of its English law meaning. If the working party intended the term to differ from the meaning in English law, it would have expressed so.

The fact that civil law countries do not recognise the concept in their domestic law does not seem to be a major cause of difficulty in interpreting and applying the beneficial ownership test. As indicated in section 1.1, the problem is that beneficial ownership cannot be applied logically as a test to corporations.

\footnotetext{
${ }^{92}$ Contrast Charl P du Toit Beneficial Ownership of Royalties in
} Bilateral Tax Treaties (IBFD, Amsterdam, 1999) at 116. 


\subsection{To what extent can the beneficial ownership concept be incorporated in double tax conventions?}

Prima facie, the interposed recipient may be a trustee, a nominee or agent, or a conduit company that is not acting as a trustee. In the context of double tax treaties, the beneficial ownership concept seems appropriate as a test for a situation in which the recipient of passive income is a trustee. Because the person who owns the income beneficially is a resident of a third country, a trustee is not considered to be entitled to a withholding tax reduction on passive income. This situation has been the subject of many studies. ${ }^{93}$ It is, however, outside the scope of this thesis. This thesis focuses on a situation where the ownership of a company is in a third country and that company does not act as a trustee. Such a situation will be referred to as a "conduit company case".

The beneficial ownership concept does not seem appropriate for deciding a conduit company case. In a substantive economic sense, a company is not capable of beneficially owning passive income. Since shareholders, who would in reality enjoy the benefit of the passive income (either because they in turn recover it or because if it is retained in the conduit company the values of their shares inherently increases), are residents of a third state, theoretically a conduit company should never be considered entitled to treaty benefits.

93 For example, International Fiscal Association Congress International Tax Treatment of Common Law Trusts: Proceedings of a Seminar held in New York in 1986 during the 40th Congress of the International Fiscal Association (Kluwer Law and Taxation Publishers, New York, 1998). John F. Avery Jones and others "The Treatment of Trusts under the OECD Model Convention" (1989) ET 379; and John Prebble "Trust and Double Taxation Agreements" (2004) 2 eJournal of Tax Research 192. 
Nevertheless, in practice courts and the OECD apply the beneficial ownership concept to conduit company cases as a test. They base their position on the conventional legal view according to which companies are both legal and beneficial owners of their assets. The problem is that, by adopting the conventional view, they tend to interpret the treaty provisions in a formal legalistic sense.

This approach is not troublesome in situations in which shareholders of a company are residents in the jurisdiction where the company is located. It is a matter of concern in conduit company cases in which shareholders are residents of a country other than a contracting state. By adopting this approach in conduit company cases, courts abandon the basic substantive economic approach with which a double tax treaty should be interpreted.

This chapter will return to this argument in section 2.22. However, before the argument can be illustrated, it is helpful to discuss the legal and economic views.

\subsection{The conventional legal view}

The application of income tax to corporations depends on the perspective from which the relationship between corporations and their shareholders is viewed. The legal perspective of the relationship between corporations and their shareholders suggests that profits should be taxed at the level of corporations and not at the level of their shareholders.

From a legal perspective, corporations are legal persons with rights equivalent to individuals. Their legal personality results in what is conventionally referred to as the "separate entity theory", according to which corporations are economically independent of their shareholders. As separate legal persons, corporations can own property, pursue legal actions, be sued and enter into 
contracts in their own name. While shareholders own corporations, they have no propriety interest in a property held by corporations. Thus, from the legal perspective, corporations are beneficial owners of their assets and income derived from these assets merely by virtue of being separate legal entities.

Justice Pitney's opinion in Eisner v Macomber ${ }^{94}$ clearly reflects this view. Although the Macomber case was not a conduit company case, his observation is relevant in the present context.

\subsection{Eisner $v$ Macomber}

The Macomber case involved Mrs. Macomber who was a shareholder in Standard Oil, which declared a stock dividend. As a result, she received bonus shares instead of a cash.

The Sixteenth Amendment to the United States Constitution empowered the Congress to tax income without regard to its source and without regard to a state's population. At the same time, the Revenue Act 1913 expressly included stock dividends under the definition of income. ${ }^{95}$ Accordingly, the Commissioner of Internal Revenue treated the bonus shares as income and taxed Mrs. Macomber. Mrs. Macomber sued the Commissioner for a refund and the United States Supreme Court decided in favour of Mrs. Macomber.

The court was concerned with the issue of whether, in accounting and legal terms, the stock dividend was to be

${ }^{94}$ Eisner v Macomber 252 Us 189 (1920).

${ }^{95}$ Revenue Act 1916 Ch 463, 39 Stat 756 (1916), §2(a). The relevant part of s. 2(a) provided: "... the term "dividends" as used in this title shall be held to mean any distribution made or ordered to be made by a corporation ... out of its earnings or profits accrued ... and payable to its shareholders, whether in cash or in stock of the corporation ... which stock dividend shall be considered income, to the amount of its cash value." 
regarded as a taxable event, rather than, whether the shareholder had gained in an economic sense. ${ }^{96}$ Ruling for the majority, Justice Pitney was of the opinion that the declaration of a stock dividend was not different economically from a cash dividend. Even when the company distributed dividends in cash, shareholders were no better off because they already owned the cash economically. ${ }^{97}$

Justice Pitney held, however, that unlike a cash dividend, the distribution of a stock dividend was not a taxable event because a company did not actually sever profits from the capital. The profits formed part of the capital and remained within the company. ${ }^{98} \mathrm{He}$ based his decision on the separate entity theory and observed: ${ }^{99}$

We have no doubt of the power or duty of a court to look through the form of the corporation and determine the question of the stockholder's right, in order to ascertain whether he has received income taxable by Congress without apportionment. But, looking through the form, we cannot disregard the essential truth disclosed; ignore the substantial difference between corporation and stockholder; treat the entire organization as unreal; look upon stockholders as partners, when they are not such; treat them as having in equity a right to a partition of the corporate assets, when they have none; and indulge the fiction that they have received and realized a share of the profits of the company which in truth they have neither received nor realized. We must treat the corporation as a substantial entity separate from the stockholder, not only because such is the practical fact but because it is only by recognizing such separateness that any dividend - even one paid in money or property - can be regarded as income of the stockholder.

\footnotetext{
${ }^{96}$ See Marvin Chirelstein Federal Income Taxation A Law Student's Guide to the Leading Cases and Concepts (9th ed, Foundation Press, New York, 2002) at 80. See also Kevin Holmes The Concept of Income A Multi-disciplinary Analysis (IBFD, Amsterdam, 2000) at 225.

${ }^{97}$ Eisner v Macomber, above n 94, at 209.

${ }^{98}$ Ibid, at 213.

${ }^{99}$ Ibid, at 213.
} 
Consequently, he analysed the facts from a legal perspective.

\subsection{The Macomber case: interpretation of beneficial ownership}

In the light of the legal perspective, Justice Pitney observed: ${ }^{100}$

... the interest of the stockholder is a capital interest, and his certificates of stock are but the evidence of it ... Short of liquidation, or until dividend declared, he has no right to withdraw any part of either capital or profits from the common enterprise; on the contrary, his interest pertains not to any part, divisible or indivisible, but to the entire assets, business, and affairs of the company. Nor is it the interest of an owner in the assets themselves, since the corporation has full title, legal and equitable, to the whole.

As discussed in section 2.12, courts have used the terms "equitable owner" and "beneficial owner" interchangeably. Justice Pitney was referring to beneficial ownership when he mentioned the equitable title of a corporation over assets, business and affairs. The observation confirms that from a legal perspective a corporation is regarded as the beneficial owner of its assets simply because it exists as a legal entity separate from its shareholders.

\subsection{The "separate entity theory" and conduit companies}

The separate entity theory applies equally to corporations with a multitude of shareholders and to closely-held corporations; that is, corporations in which one shareholder, or a few shareholders, hold all of the shares. ${ }^{101}$ It follows that, chains of corporate holdings result in the interposition of a separate legal person at each link.

${ }^{100}$ Eisner v Macomber, above n 94, at 206 (emphasis added).

${ }^{101}$ See generally Salomon v A Salomon \& Co Ltd [1897] AC 22. 
Conduit structures often involve chains of companies that are wholly owned subsidiaries of their parent companies. ${ }^{102}$ In the context of the separate entity theory, such subsidiaries would be the beneficial owners of passive income, even if they act as mere conduits.

It is hard to imagine, however, that negotiators of a double tax agreement would admit that anybody who wanted to take advantage of the agreement might do so merely by establishing a company in the jurisdiction of one of the contracting states. As early as 1925 , the League of Nations Committee of Experts expressed concern that a foreigner could maintain that he was the owner of a share and would in fact become so, but only for the period necessary to ensure that the company concerned could obtain a partial or a full exemption from a source country's (withholding) tax import. ${ }^{103}$ Further, in Re V SA the Swiss Federal Commission of Appeal in Tax Matters observed: ${ }^{104}$ "The notion of 'effective beneficiary' [usually translated as beneficial owner] clearly envisages the person who in reality receives the dividend [that was] paid rather than the formal direct shareholder ...". For this reason, it does not make sense to decide conduit company cases from a legal perspective.

\subsection{The economic perspective}

The economic perspective of the relationship between corporations and their shareholders suggests that tax

102 See OECD Committee on Fiscal Affairs "Double Taxation Conventions and the Use of Conduit Companies" in OECD Committee on Fiscal Affairs International Tax Avoidance and Evasion: Four Related Studies, Issues in International Taxation No 1 (OECD, Paris, 1987) 87 at para 4.

${ }^{103}$ Shadtai Rosenne (ed) League of Nations Committee of Experts for the Progressive Codification of International Law [1925-1928] (Oceana Publications, New York, 1972).

${ }^{104}$ Re V SA 4 ITLR 191, 208 (The Federal Commission of Appeal in Tax Matters, Switzerland). 
levied on a corporation's income should be integrated with any tax levied on its shareholders with respect to such income. According to this perspective, the dominating aspects of the relationship are the economic ownership of the assets and the profits that the corporation passes on to its shareholders or accumulates for their ultimate claim. ${ }^{105}$ Essentially, it considers who is ultimately better off as a result of the receipt of income.

In the context of the economic perspective, corporations are not viewed as economically independent of their shareholders. The perspective indicates that in a true sense corporations cannot be considered separate from the individuals who ultimately own them. A corporation is merely a vehicle through which shareholders derive income. That is, in substance, a corporation is no more capable of beneficially owning anything than it is capable of having a blood group. ${ }^{106}$

As indicated earlier, to adopt Thuronyi's analogy, conduit company schemes often involve chains of companies established as subsidiaries that have no economic reality separate from their controlling individual or corporation. Such corporations seek to obtain treaty benefits by taking advantage of the separate entity theory. They are not economic entities independent of their owners.

As discussed in section 2.3, the OECD Model Convention applies the notion of beneficial ownership to determine whether the recipient of passive income is its

${ }^{105}$ See also Peter A Harris Corporate Shareholder Income Taxation and Allocating Taxing Rights between Countries (IBFD, Amsterdam, 1996) at 45. Compare R A Musgrave "The Carter Commission Report" (1968) 1 The Canadian Journal of Economics 159 at 163.

${ }^{106}$ Victor Thuronyi "The Concept of Income" (1990) 46 Tax Law Review 45 at 78 . 
substantive economic owner. Logically, therefore, the application of the beneficial ownership test requires an analysis of facts from an economic perspective. The reasoning in Aiken Industries and the $N A G$ case illustrates the argument.

\subsection{Aiken Industries: an economic approach}

As discussed in section 2.4, Aiken contended that Industrias received the income as a Honduran corporation under Article II of the United States-Honduras double tax treaty 26 June $1956,{ }^{107}$ and therefore the interest payments should be exempt from withholding tax under the treaty. Rejecting the argument, the United States Tax Court observed: ${ }^{108}$

... while we agree with [Aiken Industries] that Industrias was a "corporation" ..., and that it therefore cannot be disregarded, we do not agree with [Aiken Industries'] conclusion that this factor alone was sufficient to qualify the interest in question for the exemption from taxation granted by article IX.

The observation reflects an economic analysis of facts. Contrary to the legal perspective, it imports that the mere existence of a corporation as a separate legal personality does not make the corporation the substantive owner of its income.

\subsection{The $N A G$ case: an economic approach}

As discussed in section 2.6, the issue before the Austrian Supreme Administrative Court was whether the Austrian tax authority was entitled to investigate whether N AG had been interposed only to extract benefits under the treaty

${ }^{107}$ Convention for Avoidance of Double Taxation and the Prevention of Fiscal Evasion with Respect to Taxes on Income, the United States-Honduras (25 June 1956, entered into force 6 February 1957). The convention was terminated on 31 December 1966.

${ }^{108}$ Aiken Industries Inc $v$ Commissioner of Internal Revenue, above $\mathrm{n}$ 48 , at 932 . 
because the "real economic owners" 109 of the income would not have been able to claim tax relief.

If the Austrian tax authority had investigated the facts from a purely legal perspective, it could have allowed treaty benefits to N AG simply by virtue of the fact that the shareholders were Swiss residents. However, tax authority investigated the arrangement beyond the shareholders of $\mathrm{N}$ AG. That is, it assessed the situation from an economic point of view. By deciding in favour of the tax authority, the court supported an economic approach.

The courts in Aiken Industries and the $N A G$ case interpreted beneficial ownership for treaty purposes. The approach adopted by these courts in the absence of the term "beneficial owner" strongly implies that, in the context of the object and purpose of double tax treaties, the notion of beneficial ownership exists as a test of substance, a test that logically requires an economic analysis of the facts.

\subsection{Economic perspective: companies can never be entitled to treaty benefits}

The context of the object and purpose of double tax treaties requires courts to analyse facts from an economic perspective; and from the economic perspective, a company cannot logically be the beneficial owner of its assets and income that the assets generate. It follows that the answer to the question whether the corporation that has immediately received passive income is the beneficial owner of that income should always be in negative. That is, the notion of beneficial ownership in the OECD Model Convention is logically not capable of being applied as a test for deciding conduit company cases.

\footnotetext{
${ }^{109}$ N AG v Regional Tax Officer for Upper Austria (2000) 2 ITLR 884
} (The Supreme Administrative Court, Austria), at 900. 
This lack of logical connection between the beneficial ownership concept and conduit companies should result in a dead end. The Authority for Advance Rulings of India reached a dead end in its NatWest Ruling. ${ }^{110}$

\subsection{The NatWest Ruling}

NatWest Bank, a resident of the United Kingdom, intended to invest in Housing Development Finance Corporation Bank Limited, a resident of India, which will be referred to as Housing Bank. In order to acquire shares in Housing Bank, NatWest Bank incorporated two wholly owned subsidiary companies in Mauritius.

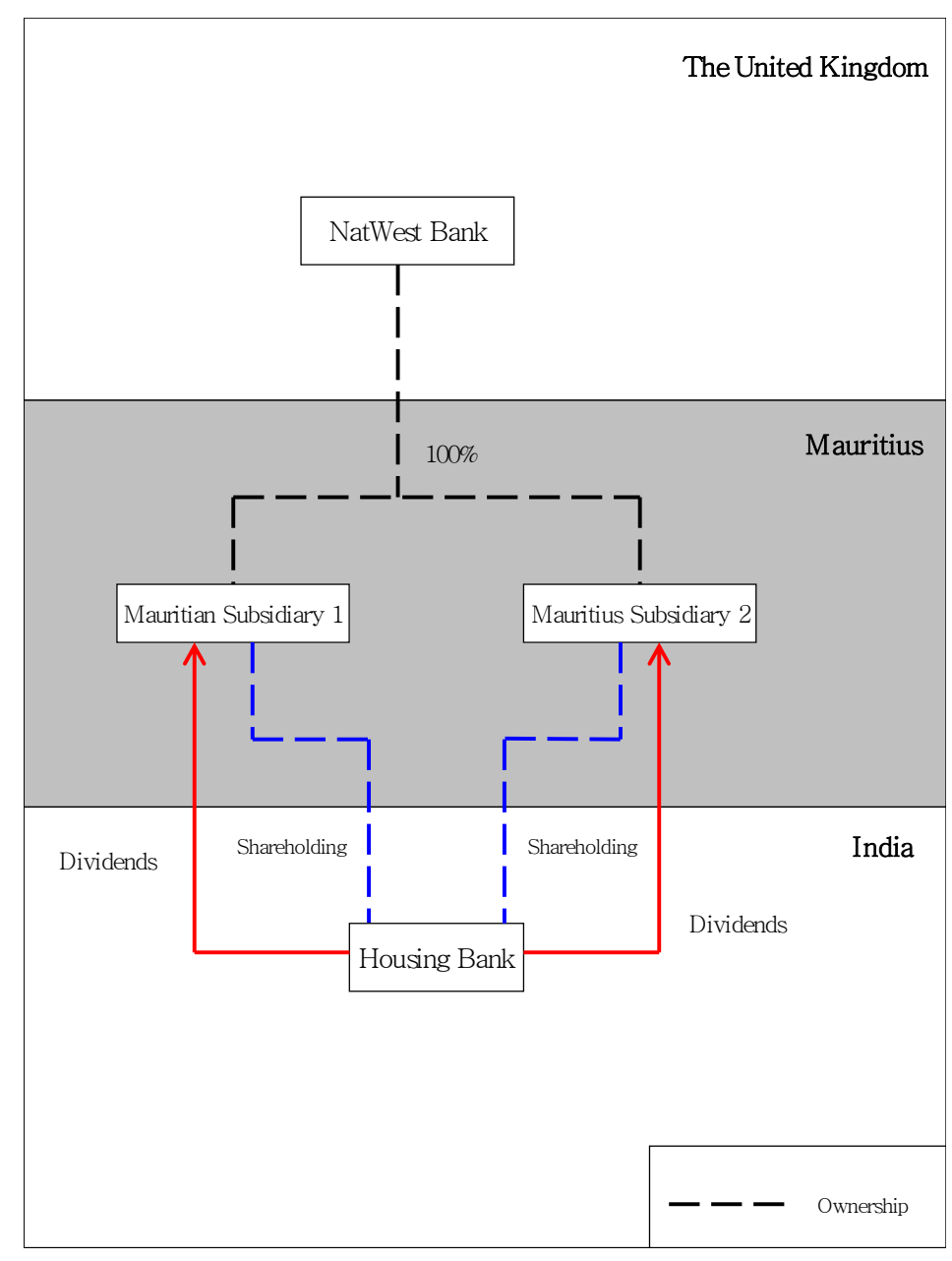

Figure 2.4: The NatWest Ruling

${ }^{110}$ In Re XYZ (1996) 220 ITR 377 (AAR) (The Authority for Advance Rulings, India). 
If NatWest Bank had directly received dividends from Housing Bank, it would have suffered a 15 per cent withholding tax in India under the double tax treaty between India and the United Kingdom. ${ }^{111}$ The IndiaMauritius double tax treaty of 24 August $1982,{ }^{112}$ on the other hand, imposed a five per cent withholding tax on dividends paid by Indian companies to Mauritian companies. Since Mauritius imposed no withholding tax on out-going dividend payments, NatWest would have made significant tax savings.

The Mauritian subsidiaries applied to the Authority for Advance Rulings of India for a confirmation that dividends paid by Housing Bank to the Mauritian subsidiaries would enjoy partial relief from withholding tax in accordance with the India-Mauritius double tax treaty.

In order to benefit from withholding tax reduction, Article 10 of the India-Mauritius double tax treaty required the recipient of dividends to be the beneficial owner of the dividends. Therefore, one of the issues before the Authority was whether the Mauritius subsidiaries qualified as the beneficial owners of the dividends paid by Housing Bank. Although the Authority considered the meaning of the term "beneficial owner", it refused to deliver a ruling on the issue of beneficial ownership.

The Authority applied section 245R(2)(c) of the Indian Income Tax Act 1961 and determined whether the

${ }^{111}$ Convention for Avoidance of Double Taxation and the Prevention of Fiscal Evasion with Respect to Taxes on Income and Capital Gains, the United Kingdom-India (25 January 1993, entered into force 25 October 1993), art 11(3).

${ }^{112}$ Convention for Avoidance of Double Taxation and the Prevention of Fiscal Evasion with Respect to Taxes on Income and Capital Gains, India-Mauritius (24 August 1982, entered into force 6 December 1983), art 10(2). 
transaction was designed prima facie for tax avoidance. ${ }^{113}$

It considered chronological events in the case and ruled against the Mauritius subsidiaries.

In the view of the Authority, there was insufficient factual data to determine whether the Mauritian subsidiaries were the beneficial owners of the shares in Housing Bank. ${ }^{114}$ However, it seems that the Authority was unable to resolve the issue because it could not reconcile two paradoxical perspectives.

\subsection{The NatWest Ruling: paradoxical perspectives}

The Authority was inclined towards the economic perspective, but somehow it found itself influenced and even restricted by the conventional view, which is based on the legal perspective. For instance, it observed: ${ }^{115}$

It is true that under Company Law, a corporation is an independent entity and cannot be said to be holding its assets or profits in trust for the shareholders. However, in view of the categorical admission that all the shares of the [Mauritian subsidiaries] are held by [NatWest Bank] and consequently, the entire funds of the [Mauritian subsidiaries] by way of share capital have been contributed by that bank, the inevitable inference is that it is [NatWest Bank] and not the [Mauritian subsidiaries] which is the real and beneficial owner of the assets of the [Mauritian subsidiaries] including the shares in [Housing Bank]. The shares as well as the income arising therefrom are held by the [Mauritian subsidiaries] only subject to the control and direction of the sole shareholder which can deal with these assets or the income therefrom in whatever manner it likes by virtue of its sole shareholding in the [Mauritian subsidiaries].

At the beginning of the observation, the Authority appears to respect the separate entity theory. If this theory were to be applied to the facts of the case, it would have meant

113 The Income Tax Act 1961 (India), s 245R(2)(c). S 245R(2)(c) provides that the Authority for Advance Rulings shall not allow an application, if after examining it the Authority is of the opinion that the application was related to a transaction that was designed prima facie for tax avoidance.

${ }^{114}$ The NatWest Ruling, above n 110, at para 16.

${ }^{115}$ Ibid, at para 15. 
that the Mauritian subsidiaries were the beneficial owners merely by virtue of being legal entities independent of NatWest Bank. At the same time, however, the Authority seems strongly influenced by the economic perspective to the extent that ${ }^{116}$ it considered NatWest Bank to be the beneficial owner of dividends because NatWest Bank was the sole shareholder of the Mauritian subsidiaries.

Later, the Authority referred with approval to the views of the editors of Gore-Brown, ${ }^{117}$ and Klaus Vogel, ${ }^{118}$ according to which even a 100 per cent interest in a subsidiary does not necessarily preclude the subsidiary's beneficial ownership in the assets it holds. These views represented the legal perspective because they are based on the separate entity theory.

The point that emerges is that the Authority was battling two paradoxical perspectives that would have led it to two opposite conclusions. On one hand, the Authority was aware that logically the beneficial ownership test required an economic analysis of the situation. On the other hand, it was prepared to adopt reluctantly the legal perspective because the conventional view is based on that perspective. The Authority reached the point where it was unable to connect the notion of beneficial ownership with conduit companies. Consequently, it was unable to deliver a ruling on the issue of beneficial ownership. Although the Authority attributed its indecisiveness to the lack of

\footnotetext{
${ }^{116}$ Since the Authority assumed that the Mauritian subsidiaries could be the beneficial owners of dividends, it could not be inferred that the Authority viewed the situation completely from an economic perspective.

${ }^{117}$ Francis Gore-Browne, A J Boyle and Richard Sykes Gore-Browne on Companies (44 ed, vol 1, Jordans, Bristol, 1986).

${ }^{118}$ Klaus Vogel Double Taxation Convention: a Commentary to the OECD-, UN-, US-Model Conventions for the Avoidance of Double Taxation of Income and Capital with particular reference to German Treaty Practice (Kluwer, Deventer, 1990) at 455.
} 
factual data, the cause of the confusion seems to be something else.

On one hand, income tax treats a company as a legal person separate from its shareholders in order to apply the beneficial ownership test. On the other hand, it cannot be denied that in a substantive economic sense, a company is not capable of owning income. This paradox is a consequence of a more general phenomenon of income tax law. John Prebble has written widely on this phenomenon, which he terms the "ectopia" of income tax law. ${ }^{119}$ Prebble's ectopia thesis yields helpful insights with respect to explaining why the OECD, courts, and commentators face difficulty in interpreting and applying the beneficial ownership concept.

\subsection{Ectopia: dislocation between the beneficial ownership test and conduit companies}

"Ectopia" means dislocation. Prebble uses the term to represent a fundamental characteristic of income tax law, which is that income tax law, by its nature, is dislocated from the reality of its subject matter. ${ }^{120}$ In the present context, this phenomenon means that the beneficial ownership test is dislocated from the reality of its subject matter, which is a company. The reality is that a company is not capable of being the beneficial owner of passive income.

Income tax law cannot tax economic transactions directly. Rather, it taxes the legal forms that are used to represent economic transactions. In order to make income

\footnotetext{
119 See John Prebble "Ectopia, Formalism and Anti-avoidance Rules in Income Tax Law" in Werner Krawietz, Neil MacCormick, Georg Henrik von Wright (eds) Prescriptive formality and normative rationality in modern legal systems : festschrift for Robert S. Summers (Duncker \& Humblot, Berlin, 1994) 367 at 378.

${ }^{120}$ John Prebble “Can Income Tax Law be Simplified?” (1996) 2 NZ Journal of Taxation Law and Policy 187 at 189.
} 
tax law work at all, the law must make many assumptions as to both the factual and the legal nature of the taxpayer's income. These assumptions are often not correct. The effect of these assumptions is that the base that the law taxes becomes disconnected from the facts of the case. ${ }^{121}$

A corporation is, in effect, a legal form that represents economic transactions between individuals who act through it and other legal persons. The example given by Prebble helps to explain the statement further. ${ }^{122}$ He states that when a company contracts to sell goods to a purchaser, the company together with company law may be seen as a legal matrix that defines the relationship between the purchaser and the individual shareholders of the company. Even though this matrix is not strictly seen as a legal relationship, this generalisation still holds good. There is always a factual relationship in that the benefit or burden of the contract will, in an economic sense, be enjoyed or borne by the company's shareholders.

In contrast to this factual position, income tax law treats companies as physical facts. In particular, the commentary on the OECD Model Convention and the Conduit Companies Report ${ }^{123}$ assumes that conduit companies are capable of deriving passive income beneficially. This assumption is a logical impossibility and causes the beneficial ownership test to be dislocated from its subject matter.

\footnotetext{
${ }^{121}$ John Prebble "Fictions of Income Tax Law" (2002) Working Paper Series No 7 Centre for Accounting, Governance and Taxation Research, Wellington.

${ }^{122}$ Prebble above n 120, at 192.

${ }^{123}$ OECD Committee on Fiscal Affairs "Double Taxation Conventions and the Use of Conduit Companies" in OECD Committee on Fiscal Affairs International Tax Avoidance and Evasion: Four Related Studies, Issues in International Taxation No 1 (OECD, Paris, 1987) at 87.
} 


\subsection{Application of the beneficial ownership test to conduit companies by the OECD}

Articles 10, 11, and 12 of the OECD Model Convention apply the beneficial ownership test to individuals as well as to companies. Furthermore, the Conduit Companies Report assumes that the notion of beneficial ownership is capable of being applied as a test to conduit companies. The report states: ${ }^{124}$

$\ldots$ a conduit company can normally not be regarded as
the beneficial owner if, though the formal owner of
certain assets, it has very narrow powers which render it
a mere fiduciary or an administrator acting on account
of the interested parties (most likely the shareholders of
the conduit company).

The proposition uses the word "normally", which leaves open the possibility that a conduit company could be regarded as the beneficial owner of passive income. That is, the OECD assumes that, at least in some situations, conduit companies can be considered beneficial owners of passive income. Thus, the Conduit Companies Report allows the beneficial ownership test to be applied to a subject matter that in fact has no relationship with the test.

\subsection{Why does the OECD assume that conduit companies are capable of being the beneficial owners of passive income?}

Generally, there is a symbiosis between law and its subject matter. That is, a law naturally relates to what the law is about. When legislators draft laws they ensure that laws are as closely related to their subject matter as can be managed. Prebble points out that this natural relationship is so sensible and obvious that legislators take it for granted. Lawmakers draft income tax laws under the same influence, seemingly unaware of the fact that the ordinary symbiosis that exists between law and its subject matter is

\footnotetext{
${ }^{124}$ The Conduit Companies Report, above n 123, at para 14(b).
} 
absent from the foundations of income tax law. ${ }^{125}$ This could be a reason why the OECD Committee on Fiscal Affairs in the Model Convention and the Conduit Companies Report seemed to assume that a symbiotic relationship existed between the beneficial ownership test and conduit companies. That is, the committee assumed that conduit companies are capable of being the beneficial owners of passive income.

Fuller's theory on legal fictions ${ }^{126}$ offers a more informative explanation. According to Fuller, "the word 'fiction' ... implies a recognition that the statement under discussion, although erroneous, had a utility". ${ }^{127}$ In the present context, the assumption that companies are capable of being the beneficial owners of passive income is a legal fiction. ${ }^{128}$ The description of conduit companies in the Conduit Companies Report shows that the OECD Committee on Fiscal Affairs was fully aware of the falsity of the assumption. The committee, however, adopted it because it is useful for trade and commerce at large.

Prebble's theory, however, differ slightly from Fuller's theory of legal fictions. While Fuller assumes that legal fictions are eliminable, Prebble identifies legal fictions that for tax purposes are being treated as if they cannot be eliminated. The assumption that conduit companies are capable of owning passive income beneficially is a legal fiction that cannot be eliminated. So much commercial life is organised on this very assumption that discarding it

\footnotetext{
125 John Prebble "Ectopia, Tax Law, and International Taxation" (1997) BTR 383 at 384.

${ }^{126}$ Lon L Fuller Legal Fictions (Stanford University Press, Stanford, 1967).

127 Ibid, at 9.

${ }^{128}$ See also Prebble above n 125, at 390.
} 
would result in discommoding current notions. ${ }^{129}$ Nevertheless, instead of facilitating the application of the beneficial ownership test, this assumption has created inconsistencies for courts in applying the test.

\subsection{Application of the beneficial ownership test to conduit companies by courts}

When courts are faced with the issue of beneficial ownership in the context of double tax treaties, they find themselves in a paradox. When interpreting the notion of beneficial ownership in the context of the object and the language of double tax treaties, courts find that the notion exists as a test to determine whether the recipient of passive income is in substance the owner. They also realise that the question can only be answered by an economic analysis, according to which companies cannot be considered capable of being beneficial owners of passive income. On the other hand, courts find that the OECD Model Convention assumes that conduit companies are, in some circumstances, capable of being beneficial owners of passive income. This assumption can be correct only if the facts of a case are evaluated from a legal perspective.

As discussed in section 2.22, this paradox should result in a situation in which a court cannot decide a conduit company case on the basis of the beneficial ownership criterion; generally, however, courts proceed with the application of the beneficial ownership test to conduit companies. That is, they prefer to assume that conduit companies are capable of being beneficial owners of passive income.

129 Ibid, at 390. See also John Prebble "Can Income Tax Law be Simplified?" (1996) 2 NZ Journal of Taxation Law and Policy 187, at 193. 


\subsection{Why do courts apply the beneficial ownership test to conduit companies?}

Fuller's theory on legal fictions further helps to understand this behaviour of courts. According to Fuller, in some cases a fiction seems to be intended to avoid the implication of a general principle of jurisprudence, or of morals. ${ }^{130}$ As mentioned earlier, in the present context, the application of the beneficial ownership test from an economic perspective could result in destabilising and bringing uncertainty to the conventional view. In Fuller's opinion, a legal fiction is a judge's way of satisfying his own craving for certainty and stability. ${ }^{131}$ Courts adopt the fiction that conduit companies are capable of beneficially owning passive income because it is consistent with the conventional view, and therefore it helps to maintain the certainty and stability of tax law. As explained in section 2.15 , according to the conventional view, companies are both the legal and the equitable owners of their assets and income generated from these assets. Consequently, courts prefer to interpret double tax agreements in general and the beneficial ownership requirement in particular from a formal legalistic viewpoint.

While doing so, courts in a sense impair the way in which double tax treaties should work. Courts find themselves, therefore, unable to justify their approach convincingly. Since courts are expected to systematise their decisions in a logically consistent manner, they tend to justify their conclusions by adopting forms of reasoning that they use as surrogate tests for the beneficial ownership test.

\footnotetext{
${ }^{130}$ Fuller above n 126, at 53.

${ }^{131}$ Ibid, at 58.
} 


\subsection{Surrogate tests}

The surrogate tests can be categorised as:

1. Substantive business activity: In order to determine whether a conduit company is entitled to a reduction in withholding tax, courts investigate whether an interposed company is involved in a substantive business activity. Courts do not consider a functionless letterbox company to be the beneficial owner. Courts have transposed the substantive business activity test from domestic tax law cases involving "nominee corporations", and from base company cases. In such cases, the courts apply the substantive business activity test as a substance over form rule.

2. Dominion: Courts determine whether a conduit company has dominion over passive income derived from the source company. The dominion test was transposed from cases involving a nominee or agent to conduit company cases. Nominees or agents receive income on behalf of a mandator or principal respectively, and therefore, they lack dominion over it. In the absence of dominion, they are under an obligation to hand over the income to the mandator or principal. For deciding whether an intermediary acts as a conduit to pass on passive income to a resident company, courts have determined whether the intermediary has dominion over the income.

Before this thesis examines the surrogate tests, it highlights in chapter 3 a substance based approach that the Swiss and Dutch courts have adopted in certain conduit company cases. The thesis advocates the substance based approach for interpreting and applying the beneficial ownership concept to conduit company cases. The 
objective of discussing the approach in chapter 3 is to use it as a yardstick in order to evaluate the surrogate tests in chapters 4 and 5 . The comparison of the surrogate test with the substance based approach not only emphasises the shortcomings of the surrogate tests, but also tests the plausibility of the substance based approach itself.

Chapters 4 and 5 illustrate that criteria by which the surrogate tests operate are not capable of applying to the concept of beneficial ownership. Consequently, when courts try to determine the issue of beneficial ownership on the basis of surrogate tests, their reasoning is often illogical. This problem may lie behind the increasingly widespread opinion that there is a need for clarification of the concept of beneficial ownership, ${ }^{132}$ although clarification may still not help.

\subsection{Conclusion}

"Beneficial ownership" essentially means the right to appropriate the benefits of a property. Domestic tax law has used the beneficial ownership concept mainly in the context of a trust in order to distinguish the rights of trustees from those of beneficiaries.

In double tax treaties, the concept operates in a slightly different context. It operates as a substantive economic test. Double tax treaties apply the concept as a countermeasure to ensure that treaty benefits are limited to residents of the contracting states. In the context of double tax agreements, the beneficial ownership test determines who is economically better off as the result of the payment of income. It ensures that a resident who is claiming the

${ }^{132}$ See OECD Committee on Fiscal Affairs "Restricting the Entitlement to Treaty Benefits" in OECD Committee on Fiscal Affairs 2002 Reports Related to the OECD Model Tax Convention (OECD, Paris, 2003) 9 at para 23. 
withholding tax reduction owns the income in substance and that resident is not under some obligation to pass on the income to a resident of a third state.

Companies are not capable of holding assets or income derived from the assets in any substantive sense. It follows that in the context of double tax agreements it does not make sense to determine whether a conduit company is entitled to treaty benefits on the basis of the criterion of beneficial ownership. Almost by definition in an economic sense, a conduit company cannot be an owner of anything. Nevertheless, the OECD and courts apply the beneficial ownership test on the basis of an assumption, often unexpressed, that conduit companies are capable of being the beneficial owners of passive income. This assumption is a logical impossibility.

Courts apply the beneficial ownership test within the wrong frame of reference. Thus, even when courts conclude that a conduit company is not the beneficial owner of passive income, their conclusion is based on reasons that are completely different from economic reality. They ignore the economic reality that a conduit company is fundamentally not capable of being the beneficial owner of anything, including passive income. 



\section{CHAPTER 3}

\section{SUBSTANCE BASED APPROACH}

3. Substance based approach ................................. 83

3.1. Introduction ................................................. 83

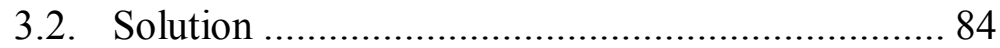

3.3. L.J. Newton v Federal Commissioner of Taxation 86

3.4. How should the word "beneficial" be interpreted? 89

3.5. The Y-group 1990 case....................................... 90

3.6. Y-group 1990: the word "beneficial" ................... 92

3.7. Y-group 1990: operation of the logic of the term "beneficial" and the predication test ..................... 94

3.8. The Re V SA case .............................................. 95

3.9. Re V SA: the word "beneficiary" ......................... 98

3.10. Re V SA: similarity between the logic of the term "beneficial" and the predication test ..................... 99

3.11. Similarity between the function of the word "beneficial" and the predication test ................... 102

3.12. The X-group 1979 case .................................... 104

3.13. "Means of the arrangement" and not "the motive of the taxpayer" ................................................... 107

3.14. "Arrangement": totality of facts ......................... 108

3.15. The Arabian-group 1984 case ........................... 110

3.16. Interpretation of the anti-abuse clause under Article 9(2)(a)(i) ....................................................... 112

3.17. Significance of the existence ............................. 112

3.18. Conclusion .......................................................... 113

\subsection{Introduction}

Chapter 2 argued that in the context of double tax conventions it is conceptually impossible to apply the beneficial ownership test to conduit companies. The test can be applied to conduit companies only if the beneficial ownership requirement is interpreted from a legalistic perspective. In summary, the process of applying the essentially substantive test of beneficial ownership by using formal, legalistic reasoning is contradictory. Apparently appreciating this problem, courts tend to turn to surrogate forms of reasoning that do not examine the concept of beneficial ownership. Although the surrogate tests are based on a substance over form approach, they 
are not necessarily suitable for deciding conduit company cases.

This chapter highlights a better substantive approach, which has been adopted by courts of Switzerland ${ }^{133}$ and the Netherlands ${ }^{134}$ for deciding a number of conduit company cases. These cases concerned tax treaty provisions that did not use the term "beneficial owner". The courts analysed the facts with the objective of determining reasons for the existence of the intermediary in the tax planning structure in question. They referred to as "reasons for the existence", "significance of the existence" or "practical significance".

They evaluated the effect of the interposition of the intermediary in order to determine reasons for its existence. Interestingly, the logic of the approach adopted by these courts corresponded to the logic of what is known as the "predication test", which was adopted by Lord Denning in the Australian case of Newton $v$ Federal Commissioner of Taxation. ${ }^{135}$ Although the Newton case dealt with a domestic tax planning scheme, it helps to explain the approach adopted by Swiss courts and the Hoge Raad.

\subsection{Solution}

Because the beneficial ownership test is fundamentally not capable of effectively deciding conduit company cases, it does not make sense to clarify the concept of beneficial ownership per se at least in the context of conduit companies. Nevertheless, when deciding conduit company

133 For example, X-group 1979 (1979) 48 Archives de droit fiscal Suisse 271 (The Federal Tax Administration, Switzerland) and Arabian-group 19841984 (1984) BGE $110 \mathrm{Ib} 287$ at 288.

134 For example, Y-group 1990, Case no 25 451, BNB 1990/45 (the Hoge Raad, the Netherlands).

${ }^{135}$ L J Newton v Federal Commissioner of Taxation (1958) 98 CLR 1. 
cases, courts tend to address the issue of beneficial ownership and the meaning of the concept. One reason is the presence of the terms "beneficial owner", "beneficially owned", or "beneficially entitled" in double tax treaties. A solution would be to replace such terms with an appropriate test specifically for conduit company cases. However, since many double tax treaties throughout the world use the terms, it will take a long time to replace them. Until treaties are amended or replaced, there is a need for a temporary solution. A temporary solution would be to interpret the word "beneficial" in the context of conduit company cases, and then, to apply the interpretation with the help of reasoning that can lead to a conclusion in a logical manner.

In the context of conduit company cases, the word "beneficial" determines whether an interposed intermediary has been inserted in order to make improper use of a double tax treaty. That is, it uses the object and purpose of a treaty to limit its benefits to residents of the contracting states. Because this principle is rather general, courts tend to adopt the surrogate tests.

The general nature of the object and purpose of limiting treaty benefits can be equated to the nature of the substance over form doctrine embedded in general antiavoidance rules. As with conduit company cases, courts in domestic tax avoidance cases tend to apply the doctrine by adopting specific tests for general anti-avoidance rules. However, in L.J. Newton v Federal Commissioner of Taxation, ${ }^{136}$ Lord Denning adopted a different approach.

The Newton case concerned the interpretation and application of section 260 of the Income Tax and Social

${ }^{136}$ L J Newton v Federal Commissioner of Taxation (1958) 98 CLR 1 (Privy Council, Australia). 
Services Contribution Assessment Act 1936-1950, which was the former Australian general anti-avoidance rule. ${ }^{137}$ Although the case dealt with a domestic dividend stripping scheme, the reasoning of the court is relevant in the present context. Lord Denning did not concretise the law by basing his decision on the absence or presence of a specific criterion. He examined overt acts of the parties in order to predicate whether the arrangement is consistent with the overall purpose of the Act. That is, he examined whether the arrangement resulted in tax avoidance. His approach is commonly referred to as the "predication test" because his formulation of the test included the verb "to predicate".

\subsection{L.J. Newton v Federal Commissioner of Taxation}

The Newton case involved a series of transactions. The underlying tax planning, however, can be summarised essentially as follows: Motor Co., a private dealer company, derived profits. Its shareholders sold their shares to Pactolus Ltd, a share trading company, at a price that included the underlying value of the shares and the anticipated dividend. Pactolus Ltd received the dividend and sold the shares back to the shareholders at the underlying value. That is, it sold the shares at a loss. The loss was a result of the dividend being stripped out by Pactolus Ltd.

\footnotetext{
${ }^{137}$ The Income Tax and Social Services Contribution Assessment Act 1936-1950 (Australia), s 260. The relevant part of s. 260 provided:

"Every contract, agreement, or arrangement made or entered into, orally or in writing ..., shall so far as it has or purports to have the purpose or effect of in any way, directly or indirectly-(a) altering the incidence of any income tax; (b) relieving any person from liability to pay income tax or make any return; (c) defeating, evading, or avoiding any duty or liability imposed on any person by this Act; or (d) preventing the operation of this Act in any respect, be absolutely void ...."
} 
Effectively, the shareholders avoided tax by converting an otherwise taxable dividend into a capital gain. Since Pactolus Ltd was a share trading company, it set off the loss in buying and selling the shares against the payment it received from Motor Co. Consequently, Pactolus Ltd. also avoided tax on the dividend, which it received from Motor Co.

The parties made all payments by cheque. They deposited the cheques simultaneously in a single bank. It was undisputed that the transactions were not shams. Prima facie, the original shareholders of Motor Co. derived no taxable income, and therefore, they were not liable to tax. However, the Commissioner assessed the shareholders for income tax with respect to the dividends. The Commissioner applied section 260 of the Income Tax and Social Services Contribution Assessment Act 19361950 and contended that the transactions formed part of an initial plan that was carried out successfully to achieve the end of avoiding tax. The Privy Council agreed with the Commissioner. In the court's opinion, section 260 covered a "concerted action to an end - the end of avoiding tax". 138

The shareholders argued that if such a wide interpretation were accorded to section 260, all transactions by which a taxpayer seeks to minimise tax would fall under the provision. To clarify the interpretation, Lord Denning adopted the predication test and observed: ${ }^{139}$

... the section is not concerned with the motives of individuals. It is not concerned with their desire to avoid tax, but only the means which they employ to do it. It affects every "contract, agreement or arrangement" ... which has the purpose or effect of avoiding tax. In

\footnotetext{
${ }^{138}$ L J Newton v Federal Commissioner of Taxation, above $\mathrm{n}$ 136, at 8. ${ }^{139}$ Ibid.
} 
applying the section you must, by the very words of it, look at the arrangement itself and see which is its effect-which it does-irrespective of the motives of the persons who made it .... In order to bring the arrangement within the section you must be able to predicate - by looking at the overt acts by which it was implemented - that it was implemented in that particular way so as to avoid tax.

When the court applied the test to the facts of the case, it was of the opinion that the series of transactions was a result of a concerted plan that section 260 referred to as an "arrangement". It found that the facts of the arrangement, which involved an exchange of cheques for similar amounts in simultaneous transactions, was enough to predicate that the arrangement sought to achieve tax avoidance as one of its ends. According to the court, the Commissioner, therefore, was entitled under section 260 to ignore all the transactions and look at the end result. The court held that the taxpayers were liable to pay tax on the dividends. ${ }^{140}$

In the context of the predication test, it could be inferred that taxpayers may plan their transactions with the intention of avoiding tax; however, courts should determine whether the effect of the arrangement as a whole is tax avoidance. That is, courts should examine the nature of the arrangement in the context of the purpose of the legislation.

The logic by which the term "beneficial" functions in conduit company cases can be equated to the logic of the application of the predication test. Before drawing an analogy between the logic of the operation of the term "beneficial" and the predication test, it is helpful to clarify the manner in which the term "beneficial owner" should be interpreted in conduit company cases.

${ }^{140}$ L J Newton v Federal Commissioner of Taxation, above n 136, at 11. 


\subsection{How should the word "beneficial" be interpreted?}

The word "beneficial" simply limits the benefit of the withholding tax reduction to residents of the contracting states. The decision of the Hoge Raad of 28 June $1989,{ }^{141}$ which will be referred to as Y-Group 1990, supports the argument. The Y-group 1990 case $^{142}$ was concerned with Article 11(3) of the 1964 Tax Arrangement for the Kingdom of the Netherlands. ${ }^{143}$ The tax arrangement is referred to as "Belastingregeling voor het Koninkrijk" in Dutch, also abbreviated as the BRK.

The BRK is a regulation that governs the fiscal relations between the Netherlands, the Netherlands Antilles and Aruba. It is also considered to be a quasi-treaty. The judgment in Y-group 1990 shows, however, that at least in terms of the taxation of dividends, the BRK works on the same principles that apply to double tax agreements. ${ }^{144}$ Although the case concerned Article 11(3) of the BRK, when denying treaty benefits to the taxpayer, the lower court of Amsterdam was of the opinion that its decision was consistent with Article 10(2) of the OECD Model of 1977 and in confirmation with the current notions of international law. ${ }^{145}$ The Hoge Raad supported the lower court's view. ${ }^{146}$

Although Article 11(3) of the BRK did not use the term "beneficial owner", the Advocate General, Mr. van Soest,

${ }^{141}$ Y-group 1990 (28 June 1989) Case no 25 451, BNB 1990/45 (the Hoge Raad, the Netherlands).

${ }^{142}$ Ibid.

${ }^{143}$ The Tax Arrangement for the Kingdom of the Netherlands (28 October 1964, entered into force 12 December 1985), art 11(3).

${ }^{144}$ See Y-group 1989, above n 141, at para 4.6.

${ }^{145}$ See "Arrest" in Y-group 1990, above n 141, at para 7.2.

${ }^{146}$ See "Beoordeling van het middel" in Y-group 1990, above n 141, at para 4.6. 
presumed that the lower court was "referring to the reservation 'if the recipient is the beneficial owner of the dividends". ${ }^{147}$ For this reason, Y-group 1990 is relevant in the present context.

\subsection{The Y-group 1990 case}

Initially, Y Canada, a Canadian company, owned all the shares of Y Netherlands, a Dutch company. Y Netherlands declared dividend. X Canada subsequently incorporated Y Antilles in the Netherlands Antilles. While Y Canada was the majority shareholder of $\mathrm{Y}$ Antilles, a Panamanian company, P Panama, held the rest of the shares. Y Netherlands paid a part of the dividend to Y Canada. Y Canada then divided the shares of Y Netherlands into preference shares and ordinary shares. Following the division, Y Canada sold the ordinary shares to Y Antilles at par value. Afterwards, Y Netherlands paid the remaining amount of the dividend to $\mathrm{Y}$ Antilles after deducting the Dutch withholding tax. Y Antilles claimed a refund of the withholding tax under Article 11(3) of the BRK. ${ }^{148}$ These events occurred within three months of each another.

147 See "Conclusie Advocaat-Generaal mr. Van Soest" in Y-group 1990, above n 141, at para 2.7 (emphasis added).

148 Tax Arrangement for the Kingdom of the Netherlands, above $n$ 143, art 11(3). 


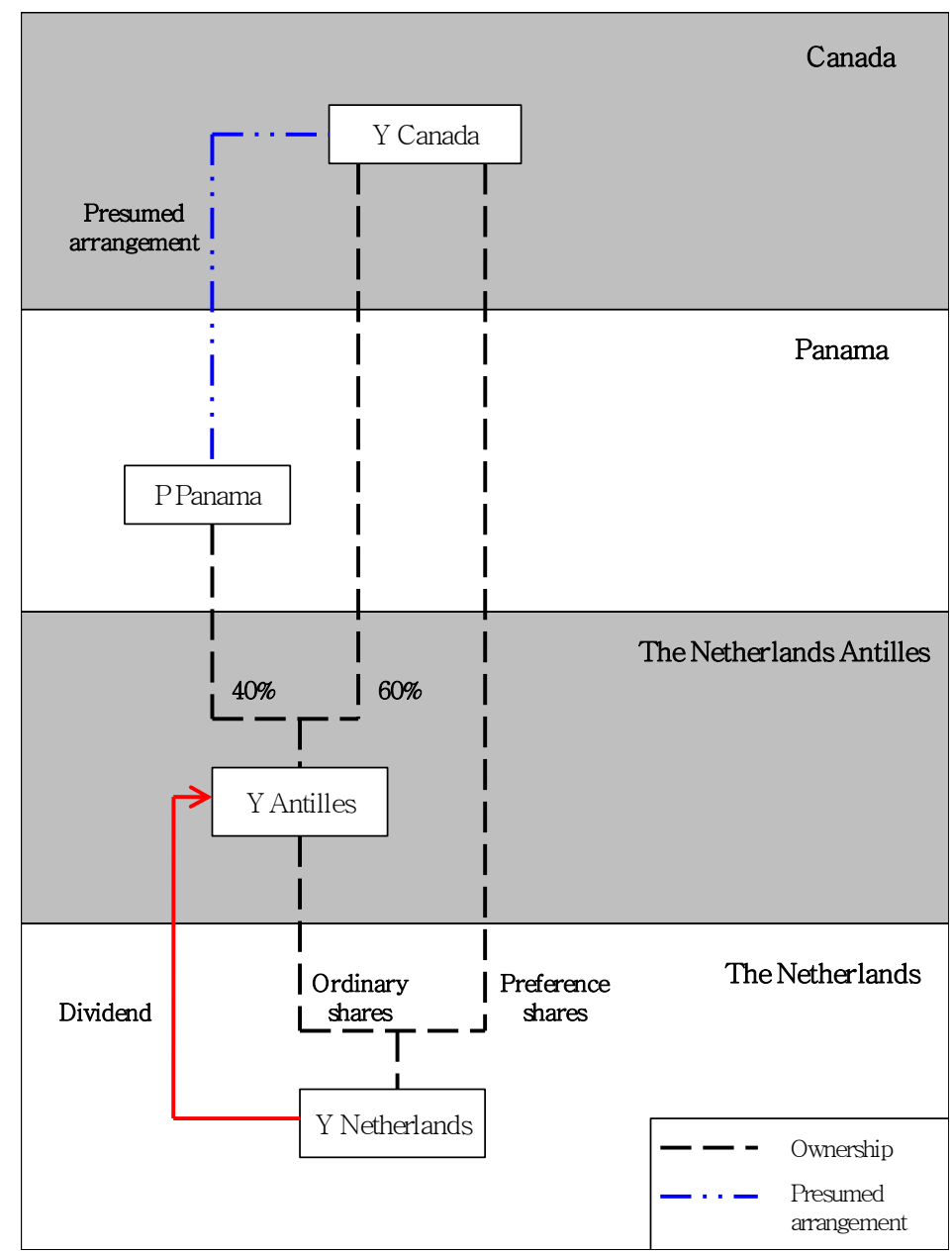

Figure 3.1: The Y-group 1990 case

When $\mathrm{Y}$ Antilles received the disputed dividend payment, Y Antilles was a letterbox company. The Dutch tax inspector asked $\mathrm{Y}$ Antilles to provide information about the beneficial owners of $\mathrm{P}$ Panama. Because $\mathrm{Y}$ Antilles did not provide the information, the tax inspector assumed that there was a contractual arrangement between P Panama and Y Canada to pass on the dividend. The tax inspector refused to grant the refund on the grounds that $Y$ Antilles was interposed solely to avoid Dutch dividend withholding tax.

Before the lower court of Amsterdam, the inspector argued that the sequence of events showed that Y Antilles had no practical significance in the corporate structure. The inspector contended that to allow the refund would be 
against the object and purpose of Article 11(3) of the BRK. The lower court agreed with the tax inspector's assessment. It held that the totality of the facts showed that the interposition of $\mathrm{Y}$ Antilles had no practical significance for the disputed dividend payment. ${ }^{149} \mathrm{Y}$ Antilles was interposed solely to avoid Dutch withholding tax on the dividend payment in question. The Hoge Raad confirmed the decision of the lower court, but placed importance on the sequence of the events. ${ }^{150}$

Since both courts found that Y Antilles had no practical significance, they were of the opinion that the arrangement should be treated as if $\mathrm{Y}$ Canada had received the dividend. They held that under such circumstances, a refund of the withholding tax would frustrate the object and purpose of Article 11(3) of the BRK. ${ }^{151}$

\subsection{Y-group 1990: the word "beneficial"}

Article 11(3) of the BRK stated: $:^{152}$

The [dividend withholding tax] ... shall not be levied, or if so levied, shall be refunded with respect to dividends derived by an entity whose capital is wholly or partly divided into shares and which is a resident of the other country and holds at least 25 per cent of the paid-up capital of the company.

Explaining the object and purpose of Article 11 of the BRK, the Hoge Raad observed (author's translation): ${ }^{153}$

... Article 11 is intended to prevent double taxation of dividends payable by a company resident in the Netherlands or the Netherlands Antilles, and enjoyed by a resident of one of these countries.

\footnotetext{
149 "Loop van het geding tot dusverre" in Y-group 1990, above n 141, at para 7.2.

150 "Beoordeling van het middel" in Y-group 1990, above n 141, at para 4.2.

151 Ibid.

152 Tax Arrangement for the Kingdom of the Netherlands, above $\mathrm{n}$ 143, art 11(3) (emphasis added).

153 "Beoordeling van het middel" in Y-group 1990, above n 141, at para 4.6.
} 
The Hoge Raad appears to interpret the words "derived by" in Article 11(3) as "enjoyed". The approach adopted by the Hoge Raad corresponds to that of the court in Aiken Industries Inc $v$ Commissioner of Internal Revenue, ${ }^{154}$ which concerned Article IX of the United States-Honduras double tax treaty of 26 June $1956 .{ }^{155}$ As with the BRK, the United States-Honduras double tax treaty did not use the term "beneficial owner". Yet, as discussed in section 2.5, the United States Tax Court in Aiken Industries explicitly read the beneficial ownership requirement into the provision. The court found that the words "received by"156 contemplated "complete dominion and control". 157 The words "received by a resident ... of the other contracting State" in the United States-Honduras double tax treaty and "paid ... to a resident of a Contract State" in the OECD Model Convention point to the same person: the immediate recipient of passive income. ${ }^{158}$ The Hoge Raad was clearly aware of the presence of the requirement of substantive economic ownership. ${ }^{159}$

The reasoning of the Hoge Raad, however, shows that it denied the withholding tax reduction essentially because

154 Aiken Industries Inc v Commissioner of Internal Revenue $56 \mathrm{TC}$ 925 (1971).

${ }^{155}$ Convention for Avoidance of Double Taxation and the Prevention of Fiscal Evasion with Respect to Taxes on Income, the United States-Honduras (25 June 1956, entered into force 6 February 1957) art IX. It stated: "Interest on ... notes ... from sources within one of the contracting States received by a resident, corporation or other entity of the other contracting State not having a permanent establishment ... shall be exempt from tax by such former State."

${ }^{156}$ The United States double tax treaty of 26 June 1956, above n 155, art IX.

157 Aiken Industries Inc v Commissioner of Internal Revenue, above $\mathrm{n}$ 154 , at 933 .

${ }^{158}$ See also Stef van Weeghel The Improper Use of Tax Treaties: with Particular Reference to the Netherlands and the United States (Kluwer, London, 1998) at 89.

159 See "Conclusie Advocaat-Generaal mr. Van Soest" in Y-group 1990, above n 141, at para 2.7 . 
Y Canada, which enjoyed the dividend, was not a resident of a country to which the BRK applied. The court emphasised the limitation of the benefit of the withholding tax reduction to residents of the contracting states of the BRK. It probably appreciated that Y Antilles could not own the dividends in a substantive economic sense, or it realised that Y Antilles did formally own the dividends as a company. Nonetheless, the reasoning for limiting the benefit of the withholding tax reduction was in alignment with the object and purpose of the OECD Model Convention in general and Article 10(2) of the OECD Model Convention in particular. ${ }^{160}$ Y-group 1990 confirms that in the context of conduit companies, the word "beneficial" could be assigned the function of limiting the benefit of a withholding tax reduction to residents of the contracting states.

\subsection{Y-group 1990: operation of the logic of the term "beneficial" and the predication test}

The approach adopted by Lord Denning in the Newton case to interpret the former Australian general antiavoidance rule appears similar to the approach adopted by the Hoge Raad. When applying the predication test, Lord Denning considered the arrangement as a whole and examined its nature in the context of the purpose of the Income Tax and Social Services Contribution Assessment Act 1936-1950. ${ }^{161}$ As with the predication test, the Hoge Raad in Y-group 1990 viewed the facts in their totality and investigated whether the interposition of $\mathrm{Y}$ Antilles was against the object and purpose of the BRK. Although

\footnotetext{
${ }^{160}$ See "Beoordeling van het middel" in Y-group 1990, above n 141, at para 4.6.

${ }^{161}$ L J Newton v Federal Commissioner of Taxation (1958) 98 CLR 1 (Privy Council, Australia).
} 
Article 11(3) of the BRK did not use the term "beneficial owner", the object and purpose of the provision was consistent with Article 10 of the OECD Model Convention. This analogy shows that the same logic applies to the use of the word "beneficial" in conduit company cases and the predication test in the Newton case. This implication is explicit in $\operatorname{Re} V S A,{ }^{162}$ concerning Article 10 of the Switzerland-Luxembourg double tax treaty of 21 January 1993, which used the term "beneficial owner". 163

\subsection{The $\operatorname{Re} V S A$ case}

As discussed in section 2.9, $\operatorname{Re} V S A$ involved two British companies that incorporated V SA in Luxembourg. V SA acquired all the capital in I SA, a Swiss company with the help of a loan from the British companies. In the initial two years of its incorporation, I SA paid dividends to V SA and deducted Swiss withholding tax.

${ }^{162}$ Re V SA (2001) 4 ITLR 191 (The Federal Commission of Appeal in Tax Matters, Switzerland).

${ }^{163}$ Convention for Avoidance of Double Taxation and the Prevention of Fiscal Evasion with Respect to Taxes on Income, SwitzerlandLuxembourg (21 January 1993, entered into force 19 February 1994), art 10(2). 


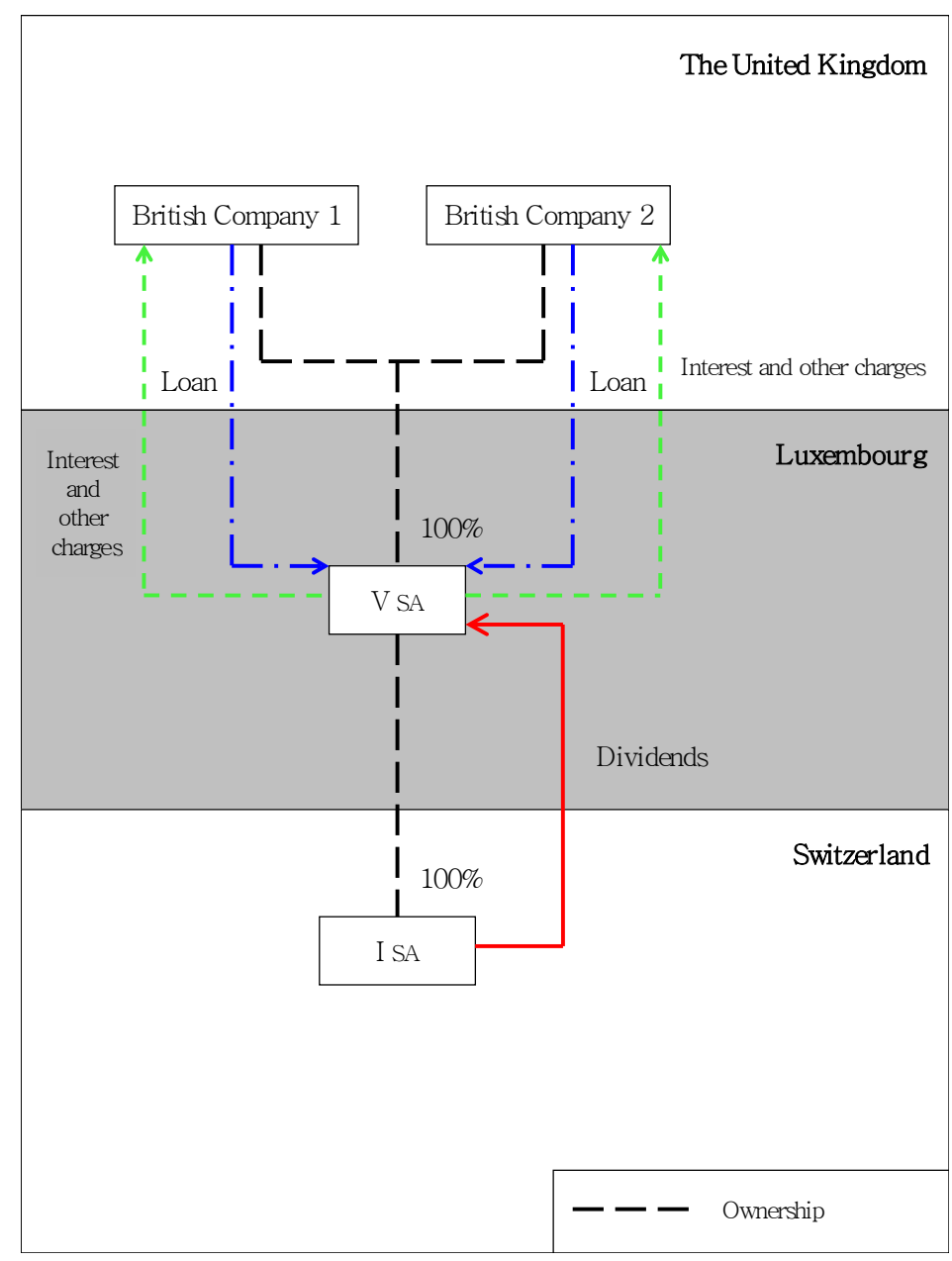

Figure 3.2: The $V S A$ case

Article 10(2) of the Switzerland-Luxembourg double tax treaty of 21 January $1993^{164}$ allows a full refund of Swiss withholding tax on a dividend payment, if a Luxembourg company has held at least 25 per cent shares of a Swiss company paying dividends for an uninterrupted period of at least two years before the date of the payment. The provision otherwise provides for a partial refund.

V SA applied to the Swiss Tax Administration for partial and full refunds of the Swiss withholding tax in accordance with Article 10(2) of the treaty. It produced annual accounts of the year in which it received the first dividend payment only, and refused to answer whether it

164 The Switzerland-Luxembourg double tax treaty of 21 January 1993, above n 163, art 10(2). 
enjoyed the benefits of both dividend payments. Consequently, the administration did not allow refunds. The Swiss Federal Commission agreed with the administration.

Because Article 10(2) uses the terms "beneficiary" and "effective beneficiary" simultaneously, ${ }^{165}$ the commission had to determine whether the term "beneficiary" should be interpreted in the same sense as "effective beneficiary" or whether it referred exclusively to the direct, formal shareholder.

In the light of Article 31(1) of the Vienna Convention, ${ }^{166}$ the commission interpreted the term "beneficiary" in three steps. First, it determined the ordinary meaning of the term. Second, it interpreted the term in the context of the purpose of the SwitzerlandLuxembourg double tax treaty. Third, it interpreted the term in the context of Article 10(2) of the treaty.

${ }^{165}$ Ibid, art 10(2). The relevant part of Article 10(2) provides:

(a) ... dividends may also be taxed in the Contracting State of which the company paying the dividends is a resident and according to the laws of that State, but if the recipient is the beneficial owner (bénéficiare effectif) of the dividends the tax so charged shall not exceed:

(i) 5 percent of the gross amount of the dividends if the beneficial owner is a company (other than a partnership) which holds directly at least 25 percent of the capital of the company paying the dividends;

(b) Notwithstanding the provisions of letter (i) of sub-paragraph a), the dividends are exempt in the Contracting State of which the company paying the dividends is a resident, if the beneficiary (bénéficiare) is a company (other than a partnership) which is a resident of the other Contracting State and which holds ..., at least 25 percent of the capital of the company paying the dividends ...

166 Vienna Convention on the Law of Treaties (23 May 1969) 1155 UNTS 331, art 31(1). It states: "A treaty shall be interpreted in good faith in accordance with the ordinary meaning to be given to the terms of the treaty in their context and in the light of its object and purpose." 
When determining the ordinary meaning of the word "beneficiary", the commission found that as with "effective beneficiary", a "beneficiary" is a person who profits economically from income. ${ }^{167}$ The commission observed: ${ }^{168}$

$\ldots$ it follows from the sense of the word beneficiary that
one cannot stop at the purely formal shareholder of a
company, but rather it is necessary to research who is
the person who can in reality and effectively benefit
from the payment of income.

The commission did not regard V SA as the beneficiary of the dividends. ${ }^{169}$ The Swiss Federal Commission might have treated its finding as conclusive; however, as with the Hoge Raad in Y-group $1990,{ }^{170}$ the commission may have realised that it was logically not possible to use the word "beneficiary" as a test for determining whether V SA was entitled to treaty benefits, and interpreted the term according to the purpose of the treaty.

\section{9. $\operatorname{Re} V S A$ : the word "beneficiary"}

To determine the purpose of the Switzerland-Luxembourg double tax treaty, the commission examined the intention of the contracting states. ${ }^{171}$ It observed that Swiss double tax treaties were intended to avoid double taxation of residents of the contracting states only. ${ }^{172}$ It noted that the companies that incorporated V SA were residents in the United Kingdom. Referring to V SA's annual accounts, it pointed out that V SA's only significant asset was its participation in I SA, and that charges that V SA paid out

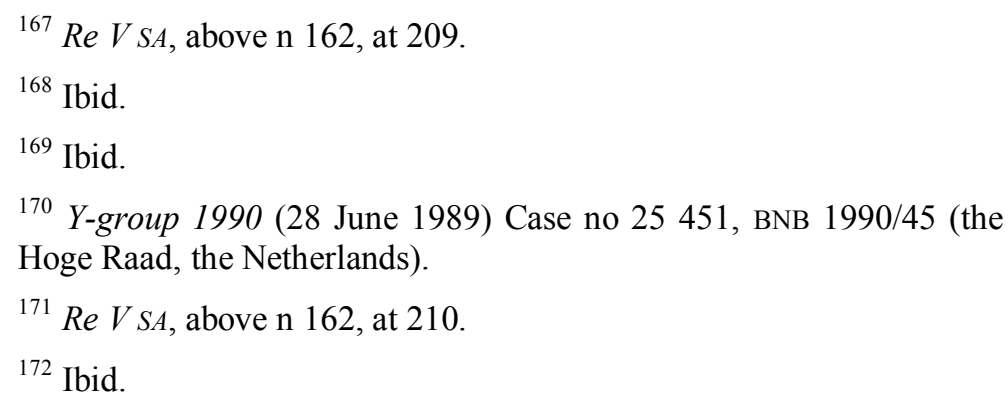


exactly covered its income. The commission found that $\mathrm{V}$

SA acted as a conduit. Consequently, it held: ${ }^{173}$

In this case, the identity of those who have the economic rights over [V SA] is not known. However, everything leads one to believe ... that it is not a Luxembourg resident ... there are sufficient indicators permitting one to conclude that [V SA] is only a shadow company interposed to permit a person who is not a resident of Luxembourg to benefit, wrongly, from the double taxation convention.

... As a consequence, if there is any double taxation, this can only arise between, on the one hand, the Swiss withholding tax and, on the other hand, the taxation of the final beneficiary of the dividends of I SA. Thus, aside from the fact that this double taxation is exclusively economic and not juridical, it is not the target of the convention concluded with Luxembourg since it is not established that the final beneficiary is a Luxembourg resident.

Thus, the deduction of withholding tax does not contravene the purpose of the convention concluded with Luxembourg which is to prevent double taxation of residents of one of the two contracting states.

The manner in which the Swiss Federal Commission interpreted "beneficiary" in accordance with the purpose of the Switzerland-Luxembourg double tax treaty corresponds to the approach adopted by the Hoge Raad in Y-group 1990. ${ }^{174}$ When interpreting the term "beneficiary", the commission emphasised the fact that the two United Kingdom companies, which had economic rights, were not residents in Luxembourg. As with the Hoge Raad it accorded the term the function of limiting the benefits to the treaty.

\subsection{0. $\operatorname{Re} V S A$ : similarity between the logic of the term "beneficial" and the predication test}

The commission subsequently interpreted the term "beneficiary" in the context of Article 10(2)(b) of the Switzerland-Luxembourg double tax treaty. It noted that the provision was adopted to permit Switzerland, in its

\footnotetext{
${ }^{173} \operatorname{Re} V S A$, above n 162, at 210.

174 "Beoordeling van het middel" in Y-group 1990, above n 170, at para 4.6.
} 
relations with Luxembourg, to benefit from Article 5(1) of the Parent Subsidiary Directive of the Council of the European Community. ${ }^{175}$ It then pointed out that Article 1(2) of the Directive ${ }^{176}$ allows the operation of antiavoidance provisions of national law and double tax treaties. It was, therefore, of the opinion that when interpreting Article 10(2) in the context of the treaty, it could apply rules of Swiss internal law aimed at combating abuse of double taxation conventions. ${ }^{177}$

The commission applied Article 21(2) of the Swiss Federal Withholding Tax Law. ${ }^{178}$ Article 21(2) is a specific statutory anti-avoidance rule, which embodies the abuse of law doctrine. It recognises that tax is avoided when: ${ }^{179}$

1. the legal form chosen by the parties appears to be unwarranted, inappropriate or unusual, and in all cases is completely inappropriate to the economic facts;

2. there is reason to believe that the choice was made abusively with the object of saving tax which would otherwise have been due if the legal relations had been arranged in an appropriate fashion;

3. the method chosen would lead effectively to a substantial reduction in tax if it was accepted by the tax authorities.

${ }^{175}$ Directive 90/435/EEC on the common system of taxation applicable in the case of parent companies and subsidiaries of different Member States [1990] OJ L225, art 5(1). It states: "Profits which a subsidiary distributes to its parent company shall, at least where the latter holds a minimum of 25 [per cent] of the capital of the subsidiary, be exempt from withholding tax."

${ }^{176}$ Ibid, art 1(2). It states: "This Directive shall not preclude the application of domestic or agreement-based provisions required for the prevention of fraud or abuse."

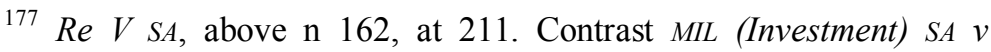
Canada 2006 TCC 460, at para 87 (Tax Court of Canada, Canada). Contrast MIL (Investment) SA v Canada 2007 FCA 236, at para 5 (Federal Court Of Appeal, Canada). (The MIL case concerns capital gains tax).

178 Verrechnungssteuergesetz [VStG] [Withholding Tax Law], 13 October 1965, SR 642.21, art 21(2) (Switz.) <www.lexfind.ch>.

${ }^{179} \operatorname{Re} V S A$, above n 162, at 212. 
The commission considered the facts that V SA was established by the British companies, which were not entitled to benefits of the Switzerland-Luxembourg double tax treaty, and that the only participation that $\mathrm{V}$ SA acquired was the shares of I SA. Based on these facts the court determined that the interposition of $\mathrm{V}$ SA lacked "serious economic justification" 180 to the extent that the structure could be described as unwarranted.

The commission could not find any non-tax reason for interposing V SA. It observed: ${ }^{181}$

One cannot see, in addition, any reason, if it is not a tax reason, that the structure was put in place. It follows that one should recognise that the participation was acquired by a Luxembourg company, in place of those having the economic rights, for purely fiscal motives.

Further, the commission found that the United Kingdom companies were able to save substantial Swiss withholding tax. It observed: ${ }^{182}$

... [V SA] has deducted from its profits, in the form of charges, an amount corresponding to the dividend received such that this dividend can in its turn exit from the Luxembourg company free of taxation. The structure put in place by [V SA] permits the recovery of the withholding tax without one being able to know whom the dividends effectively benefited.

The commission held that V SA could not be described as a "beneficiary" under article 10(2)(b) of the treaty. It seems to consider the same findings, when it refused to regard V SA as an "effective beneficiary" under Article $10(2)(a) .{ }^{183}$

Two points emerge. First, as with the Authority for Advance Ruling of India in the NatWest Ruling, ${ }^{184}$ the

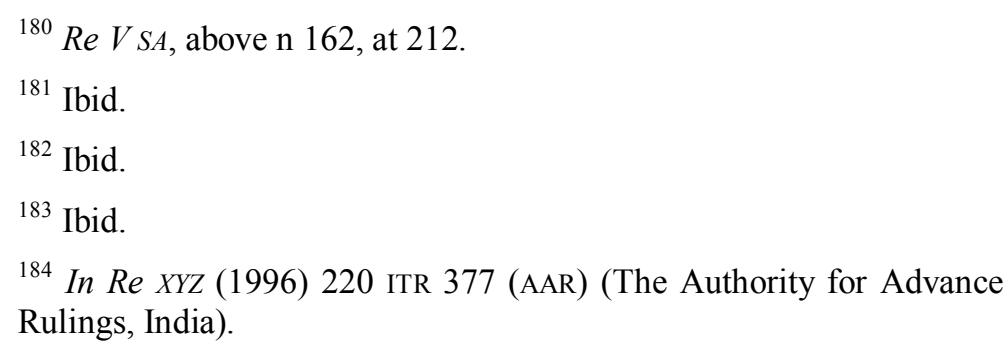


Swiss Federal Commission applied a domestic antiavoidance rule; however, unlike the Authority for Advance Ruling, the commission applied the rule as if it were applying the beneficial ownership test. As discussed in section 2.23, the Authority for Advance Ruling in the NatWest Ruling refused to determine the issue of beneficial owner and instead applied section $245 \mathrm{R}(2)(\mathrm{c})$ of the Indian Income Tax Act. ${ }^{185}$ Second, when applying Article 21(2) of the Swiss Federal Withholding Tax Law, ${ }^{186}$ the commission referred to the motive of the British companies. However, its approach resembles the approach adopted by Lord Denning in the Newton case ${ }^{187}$ to the extent that it essentially decided the case in the context of the object and purpose of the treaty and did not substitute a particular test for the beneficial ownership test.

\subsection{Similarity between the function of the word "beneficial" and the predication test}

As discussed in section 3.3, the predication test does not require courts to focus on tax avoiding motives of a taxpayer. It requires them to determine whether the effect of the arrangement, as a whole, is tax avoidance. In the context of conduit company cases, the intention of the taxpayer is to mitigate the source state withholding tax under double tax conventions. Similar to the application of the predication test, when interpreting the word

\footnotetext{
185 The Income Tax Act 1961 (India), s 245R(2)(c). S 245R(2)(c) provides that the Authority for Advance Rulings shall not allow an application, if after examining it the Authority is of the opinion that the application was related to a transaction that was designed prima facie for tax avoidance.

186 Verrechnungssteuergesetz [VStG] [Withholding Tax Law], 13 October 1965, SR 642.21, art 21(2) (Switz.) <www.lexfind.ch>.

${ }^{187}$ L J Newton v Federal Commissioner of Taxation (1958) 98 CLR 1 (Privy Council, Australia).
} 
"beneficial", courts should determine whether the interposition of an intermediary results in the improper use of the convention.

The interposition of an intermediary is an "arrangement". An examination of the arrangement as a whole requires consideration of the existing scheme, in addition to the contracting state of the double tax agreement, and a third state. The $\operatorname{Re} V S A$ case is an example of a simple conduit company scheme that involved only one intermediary. A conduit company can also be interposed in connection with other intermediaries located in jurisdictions with favourable tax regimes and extensive treaty networks. Terms of the contracts between interposed companies are drafted so that income can flow from the source to the ultimate owner through a series of transactions. In some conduit company cases, interposed intermediaries are not related either to the source company, or to the ultimate owner. An investigation of an arrangement in a conduit company case, therefore, should include a consideration of facts concerning the entire corporate structure.

As discussed in section 3.5, the lower court in Y-group $1990^{188}$ considered the facts in their totality. However, since the Y-group 1990 case does not provide information about terms of the contract between $\mathrm{Y}$ Canada and $\mathrm{P}$ Panama, the case may not help to clarify the point.

The decision of the Swiss Federal Tax Administration of 25 April 1979, ${ }^{189}$ which will be referred to as $X$-group 1979, is a better example. The conduit company scheme in that case involved several intermediaries. The terms of

\footnotetext{
${ }^{188}$ Y-group 1990, above $\mathrm{n}$ 141, at para 7.2.

${ }^{189}$ X-group 1979 (1979) 48 Archives de droit fiscal Suisse 271 (The Federal Tax Administration, Switzerland).
} 
contracts between the intermediaries were drafted in order to ensure a tax-free flow of dividends from the source company to the ultimate owner.

\subsection{The $X$-group 1979 case}

The X-group 1979 case involved Mr. N, a German resident, and the owner of the X-group. He also owned four Swiss companies that functioned as letterbox companies for sub-agents of the X-group. The Swiss companies had accumulated profits. If the Swiss companies had distributed dividends directly to $\mathrm{Mr}$. N, he would have incurred Swiss withholding tax at the rate of 15 per cent under the Switzerland-Germany double tax treaty of 11 August $1971 .{ }^{190}$ Dividend payments by Swiss companies to Dutch companies qualified for a total refund under the Article 9(2) of the Switzerland-Netherlands double tax treaty of 12 November $1951 .{ }^{191}$ It provided: ${ }^{192}$

In the case of tax on income from movable capital levied by one of the two States by deduction at source, the recipient of such income domiciled in the other State may, within a period of two years, request reimbursement through the State in which he is domiciled, subject to the production of an official certificate of domicile and of liability to direct taxation in the State of domicile:

a) in case of dividends:

(i) in the total amount of tax withheld if the recipient of such dividends is an entity whose capital wholly or partly consist of shares and which owns at least 25 per cent of the voting stock of the entity paying the dividends, provided the relation between the two entities has not been constituted or maintained

\footnotetext{
${ }^{190}$ Convention for Avoidance of Double Taxation and the Prevention of Fiscal Evasion with Respect to Taxes on Income and Capital, Switzerland-Germany, (11 August 1971, entered into force 29 December 1972), art 10(2)(c).

${ }^{191}$ Protocol to the Convention for Avoidance of Double Taxation and the Prevention of Fiscal Evasion with Respect to Taxes on Income and Property, Switzerland-the Netherlands (12 November 1951, entered into force 22 December 1966) art 9(2)(a)(i).

${ }^{192}$ Ibid.
} 
primarily for purpose of assuring receipt of the total fund.

In order to receive a total refund of the Swiss withholding tax under the treaty, Mr. $\mathrm{N}$ created the following corporate structure: he interposed a Panamanian company, which will be referred to as X Panama in which he held all of the shares. X Panama in turn held all the shares in X Curaçao, a company incorporated in the Netherlands Antilles. X Curaçao wholly owned the taxpayer, a Dutch company, which will be referred to as $\mathrm{X}$ Amsterdam. These holding companies were affiliated to the X-group.

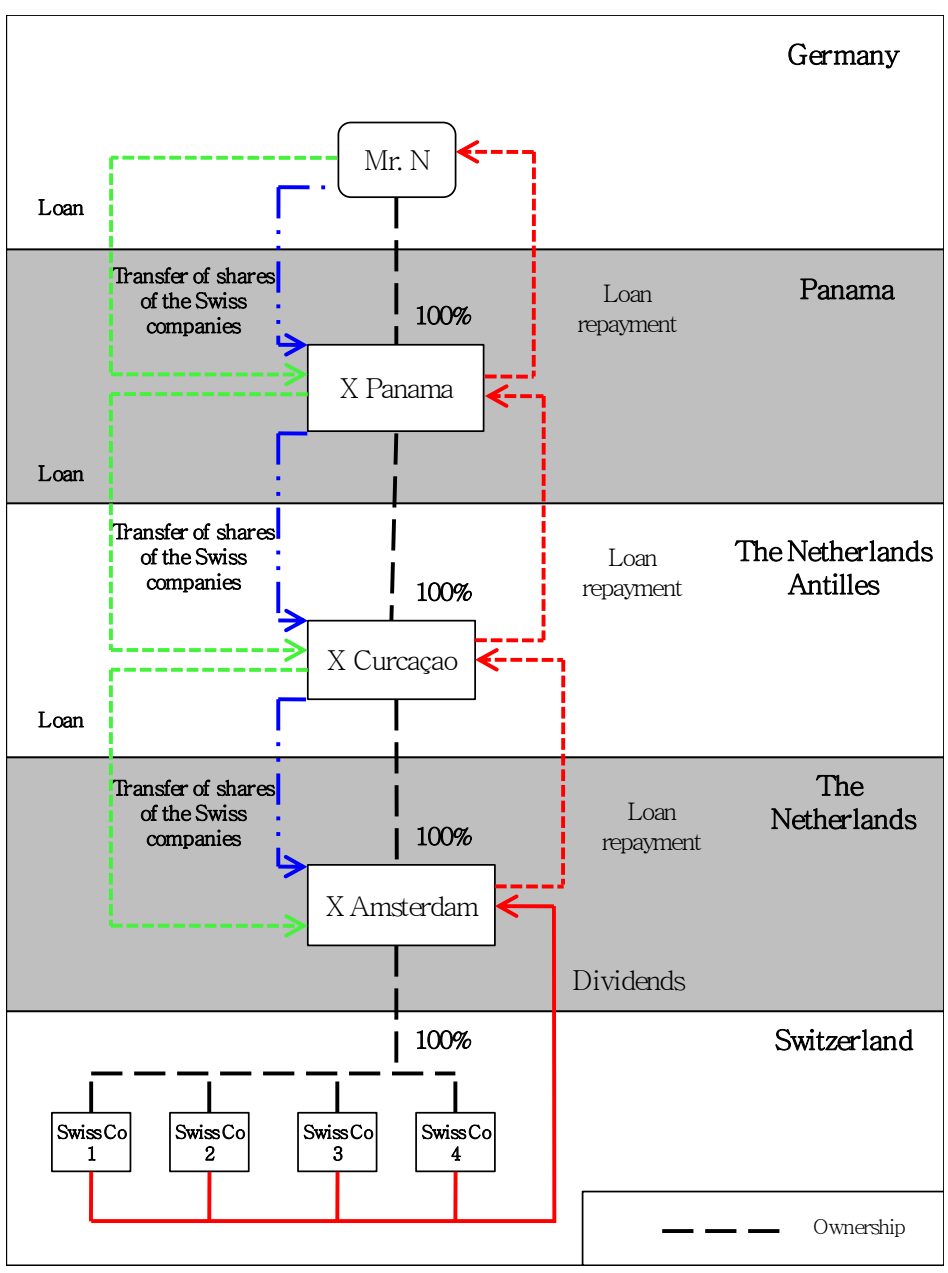

Figure 3.3: The $X$-group 1979 case

Mr. $\mathrm{N}$ then transferred the shares that he held in the Swiss companies to $\mathrm{X}$ Amsterdam through a series of transactions. First, X Panama purchased shares of the 
Swiss companies from Mr. $\mathrm{N}$ with the help of a loan from him. Similar transactions occurred in the subsequent acquisitions of the shares of Swiss companies by $\mathrm{X}$ Curaçao, and X Amsterdam. All loan contracts provided that the repayment of debts would be only out of dividend income.

The Swiss corporations withheld 35 per cent tax on dividend distributions to $\mathrm{X}$ Amsterdam. X Amsterdam applied to the Swiss Federal Tax Administration for a full refund of the withholding tax under Article 9(2) of the Netherlands-Switzerland double tax treaty. ${ }^{193}$ However, the Swiss Federal Tax Administration only allowed a partial refund under Article 9(2)(a)(ii) of the treaty. ${ }^{194}$

At the time the case was decided, Article 9(2)(a)(i) did not contain the term "beneficial owner". ${ }^{195}$ As discussed in section 2.10, in $\operatorname{Re} V S A$, the Swiss Federal Commission of Appeal in Tax Matters held that the beneficial ownership requirement does not require an express reference. ${ }^{196}$ The anti-abuse clause in Article 9(2)(a)(i) provided that a recipient of dividends who is a resident of the other state might claim the refund of the withholding tax, "provided that the relationship between the two companies has not been constituted or maintained primarily for the purpose of assuring receipt of the total fund". ${ }^{197}$

193 The Netherlands-Switzerland double tax treaty of 12 November 1951, above n 191, art 9(2)

${ }^{194}$ Ibid, art 9(2)(a)(ii). It provides that in all cases other than those covered by article 9(2)(a)(i) the amount of withholding tax that exceeded 15 per cent of the dividends would be refunded.

${ }^{195}$ It was introduced in the Netherlands-Switzerland double tax treaty of 26 February 2010.

${ }^{196}$ Re V SA 4 ITLR 191, 209.

197 The Netherlands-Switzerland double tax treaty of 12 November 1951, above n 191, art 9(2)(a)(i). 
Interpreting Article 9(2)(a)(i) in the light of its antiabuse purpose, the Swiss Federal Tax Administration observed that it was designed to prevent persons who were neither residents of Switzerland nor residents of the Netherlands from obtaining a full refund of Swiss withholding tax. ${ }^{198}$ The function that the administration accorded to the provision corresponded to the function that the word "beneficial" seems to perform in conduit company cases.

Further, the logic adopted by the Swiss Federal Tax Administration to interpret and apply the anti-abuse clause in Article 9(2)(a)(i) corresponded to the approach of the Privy Council in the Newton case to interpret Section 260 of the Income Tax and Social Services Contribution Assessment Act 1936-1950.

\subsection{3. "Means of the arrangement" and not "the motive of the taxpayer"}

When applying the Article 9(2)(a)(i), the Administration observed (author's translation): ${ }^{199}$

"Under article 9(2), the convention does not require investigating motives for which a Dutch company was established or maintained, but it requires examining whether the relation between the two companies (Dutch and Swiss) was established or maintained primarily for the purpose of obtaining the benefit of the total reimbursement of withholding tax. Therefore, the question that arises in the present case is whether the transfer of the shares of the Swiss corporations to $\mathrm{X}$ Amsterdam via $X$ Curaçao (indirectly via $X$ Panama and [Mr. N]) was effected primarily to avoid a tax burden that otherwise would have constituted withholding tax."

Essentially, the Administration clarified that it was concerned with the means by which $\mathrm{Mr}$. $\mathrm{N}$ implemented

\footnotetext{
${ }^{198}$ X-group 1979, above n 189, at 274.

${ }^{199}$ Ibid, at 275. Contrast MIL (Investment) SA v Canada 2006 TCC 460, at para 53 (Tax Court of Canada, Canada). Contrast MIL (Investment) SA v Canada 2007 FCA 236, at para 5 (Federal Court Of Appeal, Canada)
} 
the arrangement, not with his motive. ${ }^{200}$ As discussed in section 3.3, Lord Denning was of the same opinion, when he interpreted the former Australian general anti avoidance in the Newton case. ${ }^{201}$

\subsection{4. "Arrangement": totality of facts}

In order to determine whether the relationship between the Swiss corporations and $\mathrm{X}$ Amsterdam was established primarily to obtain the refund of the Swiss withholding tax, the administration considered the arrangement in its entirety.

The Administration noted that $\mathrm{Mr}$. $\mathrm{N}$ had incorporated the holding companies in countries where income from participations was exempted generally from all taxes, or in countries that had an extended network of tax treaties. The administration also considered the loan contracts between the holding companies. It inferred that interposing $\mathrm{X}$ Amsterdam ensured that the accumulated income of the Swiss companies flowed from Switzerland to Germany via the holding companies without being taxed in Switzerland. ${ }^{202}$

The Administration observed that X Amsterdam failed to show that its creation served the economic interest of the Swiss companies. The Administration did not find any economic relationship between the Swiss companies and $\mathrm{X}$ Amsterdam. Thus, according to the Administration, no "serious economic reasons" 203 existed for the incorporation of X Amsterdam. X Amsterdam argued that

\footnotetext{
200 See also "Netherlands-Switzerland Tax Treaty: Full Refund of Swiss Withholding Tax Denied” (1980) 20 ET 91 at 94.

${ }^{201}$ L J Newton v Federal Commissioner of Taxation, above n 136, at 8.

${ }^{202}$ X-group 1979, above n 189, at 277.

203 Ibid, at 275.
} 
it was created in response to economic needs of the $\mathrm{X}$ group. The Administration found that X Amsterdam had performed few financial transactions for affiliated companies and "therefore, the economic role of $\mathrm{X}$ Amsterdam, in fact was of secondary importance or virtually nonexistent.",204

Although the Administration considered a wide range of facts, its rationale shows that it analysed them in order to finding substantive economic reasons for the existence of $\mathrm{X}$ Amsterdam in the corporate structure. The Administration's objective can be compared with Lord Denning's approach in the Newton case. He analysed the facts with the objective to predicate whether the effect of the arrangement was tax avoidance. Lord Denning's approach is commonly referred to as the predication test. This thesis will refer to the Swiss Federal Tax Administration's approach as the "reasons for existence" approach.

As with the Swiss Federal Tax Administration in $X$ group 1979, the Swiss Federal Court in its decision of 9 November 1984 considered the arrangement as a whole and investigated reasons for the existence of an interposed company. ${ }^{205}$ This decision will be referred to as Arabiangroup 1984. It also dealt with Article 9(2)(a)(i) of the Netherlands-Switzerland double tax treaty; however, the Federal Court applied the provision in a slightly different manner. Unlike the Federal Tax Administration, the Federal Court placed emphasis on the intention of the taxpayer. Nevertheless, Arabian-group 1984 is useful for

\footnotetext{
${ }^{204}$ X-group 1979, above n 189, at 278 (emphasis added).

${ }^{205}$ Arabian-group 1984 (1984) BGE $110 \mathrm{Ib} 287$ at 288. See also "Dutch Holding Company not Always Entitled to a Full Refund of the Swiss Tax Withheld on Dividends from a Swiss Subsidiary" (1986) 26 ET 57.
} 
illustrating the factors that may be considered to constitute an arrangement in conduit company cases.

\subsection{The Arabian-group 1984 case}

In the Arabian-group 1984 case, certain Saudi Arabian individuals owned all the shares in $\mathrm{X}$ Marketing SA, a company in Liechtenstein. X Marketing SA wholly owned $\mathrm{X}$ Holding Co, a company established in the Netherlands Antilles. X Holding Co wholly owned X International BV, a Dutch company and the taxpayer. X International BV held 75 per cent of the shares of K AG, a Swiss company. Y Inc, a United States corporation, owned the remaining 25 per cent of the shares of $\mathrm{K}$ AG.

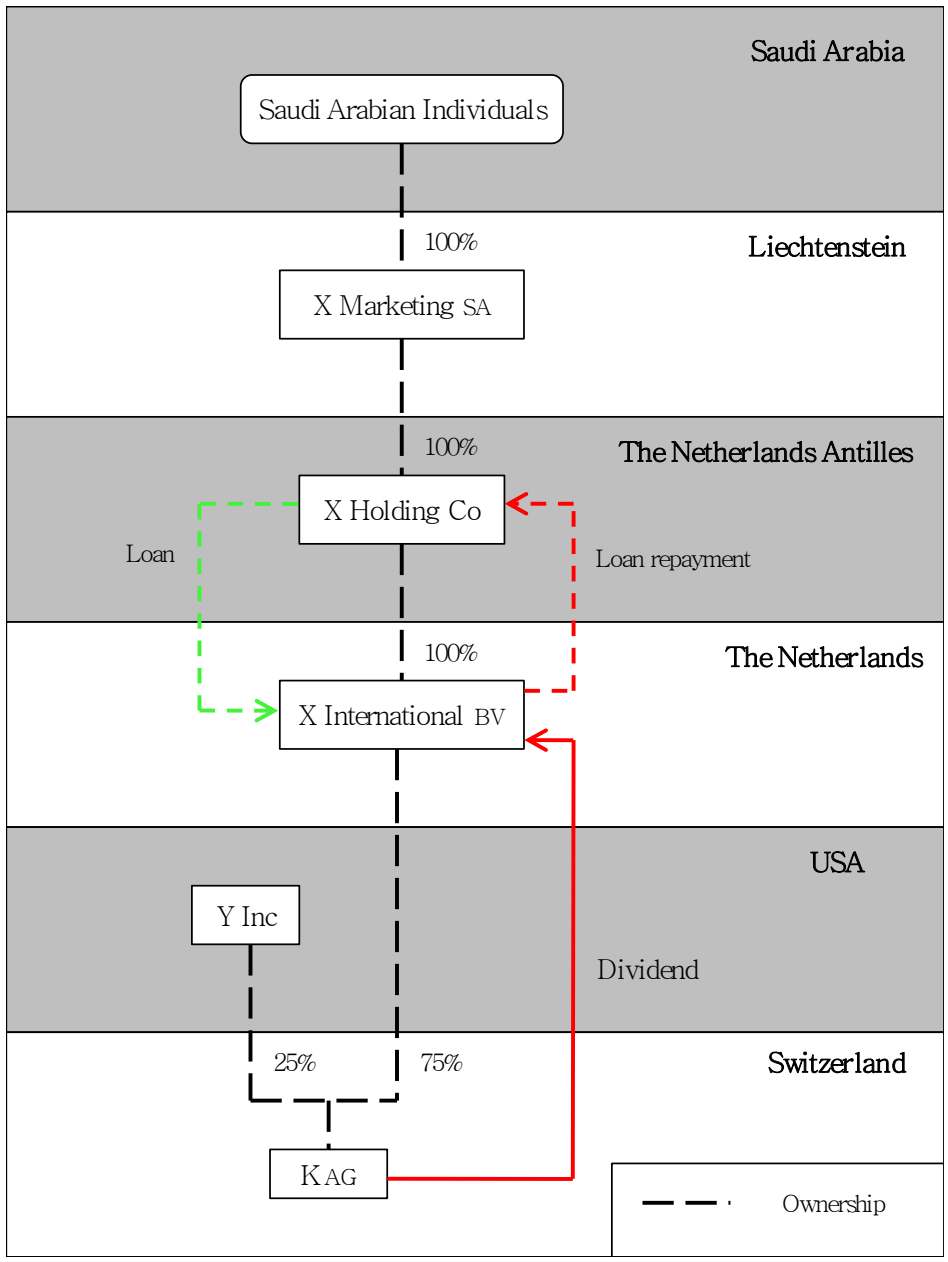

Figure 3.4: The Arabian-group case

$\mathrm{X}$ International $\mathrm{BV}$ and $\mathrm{K}$ AG were incorporated within four months of each other. $\mathrm{X}$ International $\mathrm{BV}$ had no 
business activity. Two employees of X Marketing SA acted as managing directors and sales managers of $\mathrm{X}$ International BV. They remained employees of $\mathrm{X}$ Marketing SA. X International BV had borrowed funds from $X$ Holding Co to subscribe for the shares of $\mathrm{K} A G$. To satisfy the debt, $\mathrm{X}$ International BV used the dividends distributed by $\mathrm{K}$ AG for the first time to fund the loan repayment. K AG withheld the Swiss withholding tax on the dividend payment. X International BV applied to the Swiss Tax Administration for a refund of the withholding tax under Article 9(2) of the Netherlands-Switzerland double tax treaty of 12 November $1951 .^{206}$

The Swiss tax authority denied a refund under Article 9(2)(a)(i) of the treaty on the grounds that the relationship between K AG and X International BV had been constituted and maintained principally to assure receipt of the Swiss withholding tax. The Swiss Federal Court agreed with the reason given by the tax authority to deny the full refund of the withholding tax.

Similar to the Swiss Federal Tax Administration in the $X$-group 1979 case, ${ }^{207}$ the Federal Court was in favour of interpreting Article 9(2)(a)(i) in order to prevent a resident of a third state from obtaining the benefit of a refund of Swiss withholding tax. ${ }^{208}$ However, in contrast to the opinion of the Swiss Tax Administration in the X-group 1979 case, the Swiss Federal Court seemed to focus on the intention of the individual taxpayers.

\footnotetext{
${ }^{206}$ Protocol to the Convention for Avoidance of Double Taxation and the Prevention of Fiscal Evasion with Respect to Taxes on Income and property, the Netherlands-Switzerland (12 November 1951, entered into force 22 December 1966) art 9(2).

${ }^{207}$ X-group 1979 (1979) 48 Archives de droit fiscal Suisse 271 at 274 (The Federal Tax Administration, Switzerland).

${ }^{208}$ Arabian-group 1984, above n 205, 292.
} 


\subsection{Interpretation of the anti-abuse clause under Article 9(2)(a)(i)}

It will be recalled that Article 9(2)(a)(i) provided for a full refund of withholding tax to a recipient of dividends, who is a resident of the other state, "provided that the relationship between the two companies was not established, or is not maintained, primarily in order to obtain the benefit of such total reimbursement". ${ }^{209}$ According to the court, the word "primarily" in the antiabuse clause signified that for the clause to apply, the taxpayer's desire to benefit from the full refund of Swiss withholding tax should outweigh the other reasons for choosing the Netherlands as the place of incorporation. ${ }^{210}$

In the court's opinion, the subjective element of the taxpayer's intent could only be determined by the objective circumstances of the arrangement. Therefore, as with the Swiss Tax Administration in the X-group 1979 case $^{211}$ the Federal Court investigated the facts with a view to determine the "significance of the existence of $\mathrm{X}$ International BV in the entire group". ${ }^{212}$

\subsection{Significance of the existence}

The court was of the opinion that in the context of the entire group, $\mathrm{X}$ International BV was acting as a mere conduit. ${ }^{213}$ Using the "reasons for existence" approach, the court noted that $\mathrm{X}$ International BV did not have an office, personnel, or business activity. It found that the two managing directors of $\mathrm{X}$ International BV, who also acted as its sales managers, remained employees of X Marketing

\footnotetext{
209 The Netherlands-Switzerland double tax treaty of 12 November 1951, above n 206, art 9(2)(a)(ii).

${ }^{210}$ Arabian-group 1984, above n 205, at 292.

${ }^{211} X$-group 1979, above n 207, at 278.

${ }^{212}$ Arabian-group 1984, above n 205, at 292.

213 Ibid, at 293.
} 
SA. They received their salaries exclusively from $\mathrm{X}$ Marketing SA. According to the court, X International BV failed to show that $X$ International $B V$ rendered any substantial services to $\mathrm{K}$ AG.

The court pointed out that $\mathrm{K} \mathrm{AG}$ and $\mathrm{X}$ International BV were incorporated within a short time of one another. It also considered the fact that, since the capital of $\mathrm{X}$ International $\mathrm{BV}$ was insufficient to subscribe for the shares of $\mathrm{K} \mathrm{AG}$, it borrowed from within the group. $\mathrm{X}$ International BV immediately forwarded the first dividend payment that it received from $\mathrm{K}$ AG to X Holding Co.

The court, therefore, concluded that the relationship between $\mathrm{X}$ International $\mathrm{BV}$ and $\mathrm{K}$ AG was primarily established and maintained for obtaining the benefit of the full refund of Swiss withholding tax. ${ }^{214}$

The point that emerges is that in the context of conduit companies, the arrangement as a whole may show reasons for the existence of an intermediary in the corporate structure. That is, the decision as to whether the interposition of the intermediary constitutes improper use of the convention can be based logically on this criterion.

\subsection{Conclusion}

The adoption of the "reasons for existence" approach as an interpretation of the word "beneficial" can be justified logically. The logic applied by Lord Denning to adopt the predication test seems to provide a foundation for the interpretation. The reasoning in Y-group 1990 and $X$ group 1979 and corresponds to that of Lord Denning. These cases show that, as with the predication test, the "reasons for existence" approach considers the arrangement as a whole and determines whether the effect

214 Arabian-group 1984, above n 205, at 295. 
of the arrangement is consistent with the object and purpose of a double tax treaty. X-group 1979 in particular illustrates that, similar to the predication test, the "reasons for existence" approach examines the means by which a taxpayer implements an arrangement, not his motive. Although these cases did not refer to the Newton case, their reasoning corresponds to that of the Privy Council.

The reasoning of the Swiss courts in $\operatorname{Re} V S A$ and Arabian-group 1984 differs from that of Lord Denning for the reason that they referred to taxpayers' motive to avoid tax. However, their reasoning corresponds to that of Lord Denning to the extent that they decided the cases in the light of the object and purpose of double tax treaties, which is to limit tax benefits to residents of contracting states. Moreover, they considered the arrangement as a whole and did not specify a criterion for the beneficial ownership test to work.

It is unclear from the judgments in $\operatorname{Re} V S A$ and Arabian-group 1984 whether evidence for the subjective intention of the taxpayer was produced. However, a court should consider all the available evidence. In some circumstances, the available evidence may include evidence as to the subjective intention of a taxpayer to avoid tax. When such evidence is available, there is no reason why a court should not consider it as a part of the whole matrix of facts for determining whether the arrangement contradicts the object and purpose of law.

It is interesting, but not surprising, that the reasoning adopted by civil law courts in applying the "reasons for existence" approach corresponds to that adopted by Lord Denning in the Newton case, ${ }^{215}$ which was decided in a

${ }^{215}$ L J Newton v Federal Commissioner of Taxation (1958) 98 CLR 1 (Privy Council, Australia). 
common law jurisdiction. The approach of these courts was clearly substance based. The point that emerges is that courts of both legal systems can validly adopt the "reasons for existence" approach to resolve conduit company cases.

The approach adopted by the Swiss Federal Tax Administration in X-group 1979 particularly corresponds to the predication test. As indicated earlier, this thesis will treat the administration's approach as a benchmark against which it will compare the surrogate tests in chapters 4 and 5. These chapters will also test the plausibility of reasons for existence as an alternative approach by applying it to the analysed conduit company cases.

Chapter 6 revisits certain cases that this chapter has analysed. It discusses the United States step transaction doctrine and a similar approach adopted by the Dutch courts for deciding conduit company cases. As with the application of the reasons for existence approach, when applying the step transaction doctrine, courts examine overt acts by the arrangement was implemented; however, when applying the step transaction doctrine, courts do not consider the arrangement in its entirety unlike the reason for existence approach.

As with the surrogate tests the step transaction doctrine operates by a criterion; however, this thesis treats it differently from the surrogate tests. While surrogate tests use their criteria as qualifiers for beneficial ownership, the doctrine uses its criterion as a disqualifier. For example, when applying the substantive business activity test, courts regard the presence of a business activity as an indicator of the presence of beneficial ownership; whereas chapter 6 will illustrate that in the step transaction doctrine courts consider the presence of a link between transactions to show the absence of beneficial ownership. Because this 
point can be better understood in the light of the discussion of the surrogate tests, this thesis discusses the step transaction doctrine in chapter 6 . 


\section{CHAPTER 4 \\ SUBSTANTIVE BUSINESS ACTIVITY}

4. Substantive business activity ............................ 117

4.1. Introduction ................................................... 118

4.2. The OECD on substantive business activity and beneficial ownership ......................................... 119

4.3. A Holding ApS v Federal Tax Administration..... 122

4.4. Beneficial ownership and the abuse of law doctrine 124

4.5. Beneficial ownership and the substantive business activity test...................................................... 126

4.6. Is business activity a sufficient criterion for deciding conduit company cases? .................................... 127

4.7. Is substantive business activity originally a test for deciding conduit company cases? ...................... 128

4.8. Straw corporations ............................................ 129

4.9. Difference between straw corporations cases and conduit company cases .................................... 131

4.10. Base companies.............................................. 132

4.11. Why is substantive business activity a test for base company cases? 134

4.12. Difference between base company cases and conduit company cases .................................................. 135

4.13. Northern Indiana Public Service Company $v$ Commissioner of Internal Revenue .................... 137

4.14. Northern Indiana: an illogical analogy .............. 139

4.15. Moline Properties Inc v Commissioner of Internal Revenue ........................................................... 141

4.16. Difference between Northern Indiana and Moline Properties ....................................................... 142

4.17. Hospital Corporation of America $v$ Commissioner of Internal Revenue ................................................ 144

4.18. Difference between Northern Indiana and Hospital Corporation of America ................................... 146

4.19. Section 50d(3) of the German Income Tax Act... 148

4.20. The G-group 2002 case ................................... 151

4.21. G-group 2002: another analogy with base company

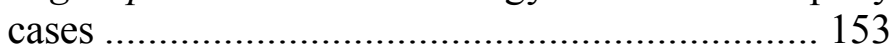

4.22. Is business activity a conclusive criterion for deciding conduit company cases? ..................... 154

4.23. The G-group 2005 case .................................... 155

4.24. Interpretation of section $50(\mathrm{~d})$ in the light of base company cases

4.25. What constitutes substantive business activity? .. 160

4.26. Does profit spread indicate business activity?.... 161

4.27. Revenue Ruling 84-153: profit spread is not relevant at all ......................................................... 164

4.28. Reasons for the existence of Finance ................. 167 
4.29. Can holding shares constitute a business activity? 169

4.30. Reasons for the existence of the Dutch subsidiaries 172

4.31. The amended section 50d(3) of the EStG............ 173

4.32. The Bank of Scotland case............................... 175

4.33. Would section $50 \mathrm{~d}(3)$ have worked in the facts and circumstances of Bank of Scotland?................... 178

4.34. Conclusion......................................................... 179

\subsection{Introduction}

Section 2.30 categorised two surrogate tests that courts use in order to apply the beneficial ownership test. The substantive business activity test is one such test. As the name suggests, the test considers whether a company is involved in a substantive business activity. The test is also referred to as "substantive business operations",216 or simply "economic activity". 217

Originally, courts developed the substantive business activity test as a substance over form rule for determining whether the law should recognise domestic "straw companies" and foreign base companies as taxable entities separate from their shareholders. The OECD, courts, and the German legislature have extended the application of the test to decide cases of improper use of double tax conventions through conduit companies. These authorities, however, fail to apply the criterion of business activity as a test to conduit company cases in a logical manner. A conduit company case turns on the issue of whether an intermediary is the beneficial owner of passive income, or whether it should be classed as merely a conduit that

\footnotetext{
${ }^{216}$ OECD Committee on Fiscal Affairs "Double Taxation Conventions and the Use of Conduit Companies" in OECD Committee on Fiscal Affairs International Tax Avoidance and Evasion: Four Related Studies, Issues in International Taxation No 1 (OECD, Paris, 1987) 87 at para 42 (ii).

${ }^{217}$ Einkommensteuergesetz [EStG] [Income Tax Act], 16 October 1934 RGBl I at 1005, §50d, $₫ 3$.
} 
passes passive income on to persons who are not residents of contracting states. This chapter argues that business activity cannot be considered to be an indicator of beneficial ownership. With the help of case analysis, the chapter illustrates that although the absence of business activity shows that an interposed company lacks substance, its presence does not necessarily mean that a company cannot be characterised as a conduit.

Despite the fundamental error of logic, courts have decided conduit company cases on the basis of the criterion of business activity. This chapter illustrates that in the process of treating business activity as a sufficient criterion, in some cases courts have in effect recognised tax avoidance as substantive business activity.

\subsection{The OECD on substantive business activity and beneficial ownership}

The Conduit Companies Report ${ }^{218}$ and the commentary on Article 1 of the OECD Model Convention ${ }^{219}$ refer to substantive business operations in terms of "bona fide" provisions. Both the Conduit Companies Report and the commentary suggest limitation on benefits provisions that negotiators may include in double tax conventions as safeguards against conduit company schemes.

In the provisions, the "look-through approach",220 uses ownership as a criterion, in addition to the criterion of

\footnotetext{
${ }^{218}$ The Conduit Companies Report, above n 216 at para 42(ii).

219 OECD Committee on Fiscal Affairs "Commentary on Article 1 concerning the Persons Covered by the Convention" in OECD Committee on Fiscal Affairs Model Tax Convention on Income and on Capital (OECD, Paris, 2010) 64 at para 19(b).

${ }^{220}$ Ibid, at para 13. The Conduit Companies Report above n 216, at para 23. The look-through approach states: "A company that is a resident of a Contracting State shall not be entitled to relief from taxation under this Convention with respect to any item of income, gains or profits if it is owned or controlled directly or through one or more companies, wherever resident, by persons who are not residents of a Contracting State."
} 
control. The "subject-to-tax approach" 221 and the "channel approach" 222 apply the concept of "substantial interest". Although they do not define the concept, they seem to use it in the sense of ownership. The "exclusion approach"223 does not consider the criterion of ownership at all. The point is that although the specific provisions do not use the term "beneficial owner", most of them deploy the same principle that the term does, which is substantive economic ownership.

${ }^{221}$ Commentary on Article 1 of the OECD Model Convention, above $\mathrm{n}$ 219, at para 15. The Conduit Company Companies Report above $\mathrm{n}$ 216, at para 29. The subject-to-tax approach states "Where income arising in a Contracting State is received by a company resident of the other Contracting State and one or more persons not resident in that other Contracting State

a) have directly or indirectly or through one or more companies, wherever resident, a substantial interest in such company, in the form of a participation or otherwise, or

b) exercise directly or indirectly, alone or together, the management or control of such company,

any provision of this Convention conferring an exemption from, or a reduction of, tax shall apply only to income that is subject to tax in the last-mentioned State under the ordinary rules of its tax law."

${ }^{222}$ Ibid, para 17. The Conduit Companies Report, above n 1, para 37. The channel approach states: "Where income arising in a Contracting State is received by a company that is a resident of the other Contracting State and one or more persons who are not residents of that other Contracting State

a) have directly or indirectly or through one or more companies, wherever resident, a substantial interest in such company, in the form of a participation or otherwise, or

b) exercise directly or indirectly, alone or together, the management or control of such company

any provision of this Convention conferring an exemption from, or a reduction of, tax shall not apply if more than 50 per cent of such income is used to satisfy claims by such persons (including interest, royalties, development, advertising, initial and travel expenses, and depreciation of any kind of business assets including those on immaterial goods and processes)."

223 The Conduit Companies Report, above n 216, at para 26. Taxpayers can create conduit structures by using tax-exempt companies, which may be distinguished by special legal characteristics. The exclusion approach prevents abuse of a treaty by denying treaty benefits to such companies. 
These safeguard provisions against conduit companies are general in nature. Therefore, in order to ensure that treaty benefits are granted in bona fide cases, the Conduit Companies Report ${ }^{224}$ and the commentary ${ }^{225}$ recommend that "bona fide" provisions should accompany the safeguard provisions. The "activity provision", which is one of the bona fide provisions, provides that the safeguard provisions: ${ }^{226}$

shall not apply where the company is engaged in substantive business operations in the Contracting State of which it is a resident and the relief from taxation claimed from the other Contracting State is with respect to income that is connected with such operations.

By overriding the safeguard provisions that apply the criterion of substantive economic ownership, the "activity provision" effectively overrides the beneficial ownership test. That is, by implication it treats the criterion of business activity as decisive.

Moreover, paragraph 119 of the 1998 report of the OECD on harmful tax competition ${ }^{227}$ states that companies with no economic function incorporated in tax havens can be denied treaty benefits because these companies are not considered to be beneficial owners of certain income formally attributed to them. The statement suggests that the OECD Committee on Fiscal Affairs considers that there is a causal relationship between business activity and beneficial ownership. However, that cause and effect relationship does not make sense. Even if the beneficial

\footnotetext{
${ }^{224}$ The Conduit Companies Report, above n 216, at para 42.

${ }^{225}$ Commentary on Article 1 of the OECD Model Convention, above $n$ 219 , at para 19 .

${ }^{226}$ The Conduit Companies Report, above n 216, at para 42(ii). See also Commentary on Article 1 of the OECD Model Convention, above n 219, at para $19(\mathrm{~b})$.

227 OECD Committee on Fiscal Affairs International Harmful Tax Competition an Emerging Global Issue (OECD, Paris, 1998), at para 119.
} 
ownership test is accorded a legalistic interpretation, the mere absence of business activity does not logically prevent a person from owning anything any more than its presence necessarily implies the existence of ownership.

The Swiss case of A Holding ApS v Federal Tax Administration $^{228}$ illustrates the foregoing points.

\subsection{A Holding ApS v Federal Tax Administration}

This case involved a group of companies that was controlled by Mr. E, an individual resident in Bermuda. Mr. E was the director of D Ltd, a Bermudan corporation, which held all the shares in C Ltd, a subsidiary company resident in the Channel Islands. C Ltd wholly owned A Holding ApS, a Danish holding company, which will be referred to as A Holding. A Holding was the taxpayer. It acquired the entire issued share capital of $F$ AG, a Swiss company. A Holding did not have its own offices or staff in Denmark and had no entries for assets, leasing or personnel expenditure in its books. F AG distributed dividends to A Holding, which were subjected to 35 per cent withholding tax under Swiss domestic tax law.

${ }^{228}$ A Holding ApS v Federal Tax Administration (2005) 8 ITLR 536 (The Federal Court, Switzerland). 


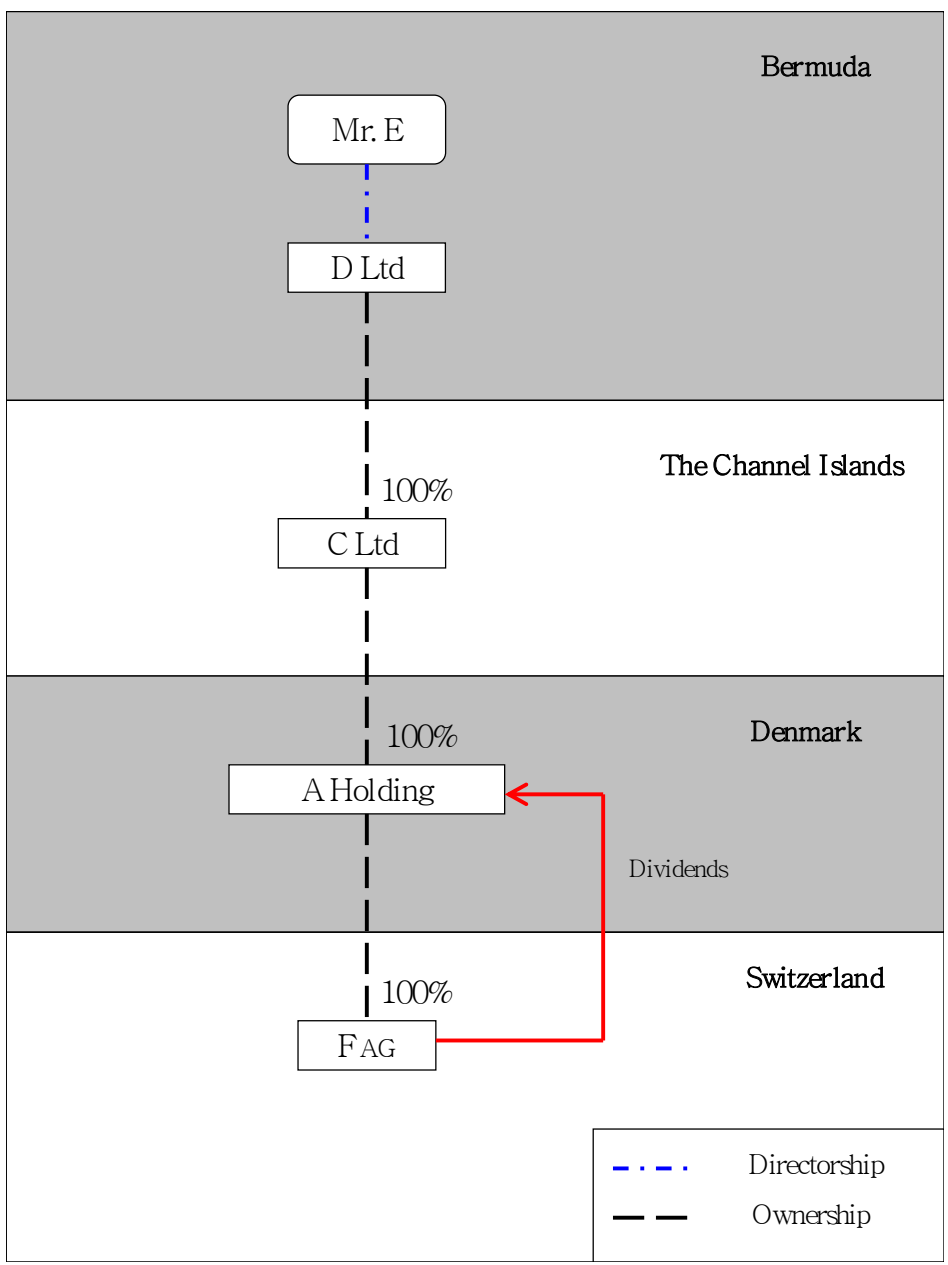

Figure 4.1: A Holding ApS v Federal Tax Administration

A Holding applied for a refund of the withholding tax under Article 26(2) of the Switzerland-Denmark double tax treaty of 23 November $1973 .{ }^{229}$ The Swiss Federal Tax Administration and the Higher Tax Administration rejected A Holding's application.

Since the Switzerland-Denmark double tax treaty did not have a beneficial ownership provision, ${ }^{230}$ both courts applied the abuse of law doctrine. They found that A Holding did not carry out a real economic activity. They,

${ }^{229}$ Convention for Avoidance of Double Taxation on Income and Capital, Denmark-Switzerland (23 November 1973, entered into force 1 January 1974), art 26(2). It provides, “... the tax withheld (at the source) shall be reimbursed upon application, in so far as the levying thereof is restricted by the Agreement."

230 The beneficial ownership requirement was introduced to the Switzerland-Denmark double tax treaty in August 2009. 
therefore, held that A Holding was interposed solely for the purpose of obtaining benefits of the treaty. The Higher Tax Administration, however, considered A Holding to be the beneficial owner. The Swiss Federal Court confirmed the decision of the Higher Tax Administration and explained its reasons for applying the abuse of law doctrine and the substantive business activity test.

\subsection{Beneficial ownership and the abuse of law doctrine}

In appeal before the Swiss Federal Court, A Holding argued that in the absence of an anti-abuse provision from the Switzerland-Denmark double tax treaty, the abuse of law doctrine could not be construed into the treaty. A Holding also contended that the fact that it was the beneficial owner of the dividend (as found by the Higher Tax Administration) was sufficient to exclude the application of the abuse of law doctrine. ${ }^{231}$ A Holding's submissions seem to accept impliedly that the beneficial ownership test and the predication test address the same issue.

The Federal Court rejected A Holding's first argument and interpreted the Switzerland-Denmark double tax treaty in accordance with Articles 26, ${ }^{232}$ and $31(1)^{233}$ of the Vienna Convention. It was of the opinion that prohibition of abuse forms part of the principle of good faith. ${ }^{234}$ In order to ascertain the aim and purpose of the Switzerland-

\footnotetext{
${ }^{231}$ A Holding ApS v Federal Tax Administration, above n 228, 554.

${ }^{232}$ Vienna Convention on the Law of Treaties (23 May 1969, entered into force 27 January 1980), art 26. It states: "Every treaty in force is binding upon the parties to it and must be performed by them in good faith."

${ }^{233}$ Ibid, art 31(1). It states: "A treaty shall be interpreted in good faith in accordance with the ordinary meaning to be given to the terms of the treaty in their context and in the light of its object and purpose."

${ }^{234}$ A Holding ApS v Federal Tax Administration, above n 228, at 557.
} 
Denmark double tax treaty, the court referred to the official commentary on Article 1 of the OECD Model Convention of $2003^{235}$ and held that states do not have to allow treaty benefits if the arrangement chosen by the taxpayer constitutes abuse of the convention. ${ }^{236}$ That is, the court found the abuse of law doctrine to be consistent with the aim and purpose of the OECD Model Convention. In essence, the court read the abuse of law doctrine into double tax treaties.

The Federal Court rejected A Holding's second contention and observed: ${ }^{237}$

\begin{abstract}
Although the Higher Tax Administration has regarded [A Holding] as the beneficial owner of the dividends in accordance with art 10 [of the Switzerland-Denmark double tax treaty] one can assume an abuse. The assumptions of the court of lower instance were based on the fact that the distributed dividends are in principle attributable to [A Holding] for taxation in Denmark ...; this does not answer the question whether the convention was invoked abusively .... .
\end{abstract}

As discussed in section 3.10, the reasoning of the Swiss Federal Commission of Appeal in Tax Matters shows that the term "beneficial owner" codifies the abuse of law doctrine. $^{238}$ The observation suggests, however, that the Swiss Federal Court distinguished the meaning if between the beneficial ownership test and the domestic anti-abuse principle. The court distinguished the meaning of beneficial owner for legal purposes from its meaning for the purposes of double tax treaties. The Higher Tax Administration considered A Holding to be the beneficial

\footnotetext{
235 OECD Committee on Fiscal Affairs "Commentary on Article 1 concerning the Persons Covered by the Convention" in OECD Committee on Fiscal Affairs Model Tax Convention on Income and on Capital (OECD, Paris, 2003) 49 at para 9.4.

${ }^{236}$ A Holding ApS v Federal Tax Administration, above n 228, at 558.

237 Ibid, at 559.

${ }^{238}$ Re V SA (2001) 4 ITLR 191 (The Federal Commission of Appeal in Tax Matters, Switzerland).
} 
owner because the dividends were in principle attributable to A Holding. The reasoning of the Higher Tax Administration corresponds to conventional legal perspective on the application of the beneficial ownership test to companies. When the Swiss Federal Court agreed with the reasoning of the Higher Tax Administration, it applied the beneficial ownership test legalistically.

\subsection{Beneficial ownership and the substantive business activity test}

Since the treaty had no anti-abuse provision, the Federal Court implemented the abuse of law doctrine using the "look-through" provision, ${ }^{239}$ which it referred to as the "transparency provision". ${ }^{240}$ It noted that the corporate structure allowed Mr. E to control not only D Ltd, but also A Holding. According to the court, in these circumstances allowing a refund to A Holding would have meant granting the refund to $\mathrm{Mr}$. E. ${ }^{241}$

As explained in section 4.2, due to the general nature of the limitation on benefits provisions against conduit companies, the OECD Model Convention recommends that these provisions should be drafted also into double tax agreements with "bona fide" provisions. The Federal Court relied on the "activity provision" and observed: ${ }^{242}$

If the convention does not contain an explicit anti-abuse provision-[as] in the present case-an abuse can, based on the transparency provision, only be assumed if [A Holding] additionally does not carry out a real economic activity or an active business activity ...

It follows that the objection of an abuse of a convention is unfounded if the company demonstrates that its main purpose, its management and the acquisition as well as the holding of participations and

\footnotetext{
${ }^{239}$ Commentary on Article 1 of the OECD Model Convention of 2003, above n 235, at para 13 .

${ }^{240}$ A Holding ApS v Federal Tax Administration, above n 228, at 560.

241 Ibid.

${ }^{242}$ Ibid (emphasis added).
} 
other assets from which the income in question arises is primarily based on valid economic grounds and not aimed at the obtaining of advantages of the applicable double tax convention ([the] so called 'bona-fide' provision). The same applies if the company pursues effectively a commercial activity in its state of residence and the tax relief claimed in the other contracting state relates to income connected to this activity (so called activity-provision).

The court found that A Holding was not engaged in a business activity and held, therefore, that A Holding was not entitled to the withholding tax refund under the Switzerland-Denmark double tax treaty. In the process of applying the abuse of law doctrine, the court chose effectively to base its decision on the criterion of business activity. That is, the court considered substantive business activity to be a surrogate of the abuse of law doctrine.

As discussed in section 4.4, the court applied the beneficial ownership test in a formal legalist sense and considered the abuse of law doctrine separately from the beneficial ownership test. It follows that the court considered beneficial ownership (which it found to be present) and substantive business activity (which it found independently to be absent) to be two different tests. The reasoning supports the point that the criterion of business activity does not relate causally to ownership, even if the beneficial ownership test is interpreted in a legalistic sense.

\subsection{Is business activity a sufficient criterion for deciding conduit company cases?}

As discussed earlier, when the court applied the lookthrough approach, it used the activity provision as a bona fide provision. In the observation quoted in section 4.5 , the Federal Court used the phrase "can ... only be assumed if". ${ }^{243}$ The usage shows that the court treated business

${ }^{243}$ A Holding ApS v Federal Tax Administration, above n 228, at 560. 
activity as if it were a sufficient criterion for determining whether an intermediary could be considered to function as a mere conduit. The observation confirms the point that the activity provision implies that substantive business activity is a decisive criterion for determining whether an interposed company is a conduit.

The business activity test led the Swiss Federal Court to a correct conclusion because A Holding, as a conduit company, was not involved in a business activity. It does not, however, make sense to base the decision of a conduit company case solely on the business activity criterion because the presence of business activity does not necessarily show that an interposed company should not be categorised as a conduit company.

The point is that, although business activity may be a useful element of the substance over form approach embodied in the abuse of rights doctrine, in conduit company cases it is hard to arrive at a logical conclusion on the basis of the presence or absence of this element. Notwithstanding this fundamental error of logic, courts have considered substantive business activity to be a sufficient criterion for deciding conduit company cases. For this reason, it becomes important to examine the reasoning underlying their decisions.

\subsection{Is substantive business activity originally a test for deciding conduit company cases?}

Substantive business activity was originally not a test for conduit company cases. Courts in general developed the substantive business activity test as a substance over form test for deciding cases involving foreign "base companies". The United States courts, in particular, have also applied the test for determining tax issues that arise in cases involving domestic "straw companies". These cases 
tend to turn on the issue of whether a base company, or a straw company, should be treated as a taxable entity separate from its shareholders. Courts have decided the issue on the basis of the business activity of a company. Consequently, they treat business activity as a sufficient criterion in both base company cases and straw company cases.

Tax planning schemes involving base companies and straw companies specifically could misleadingly resemble conduit company cases in the context of company structures employed by taxpayers to obtain tax advantages. For this reason, courts have transposed the application of the substantive business activity test from straw company cases and base company cases to conduit company cases. However, they have failed to recognise that a conduit company case turns on a completely different issue that cannot be determined solely on the basis of the substantive business activity test. Before explaining the distinction, it is helpful to describe straw companies and base companies.

\subsection{Straw corporations}

In the United States, the terms "straw corporations" or "nominee corporations" represent companies that are used for non-tax reasons in business transactions usually related to real estate. A straw corporation merely holds legal title to a property. Its shareholders, or a third party, own the property beneficially.

Non-tax reasons for employing a straw corporation may include: avoidance of personal liability for loans obtained to acquire, improve or refinance property in real estate 
ventures ${ }^{244}$ protection from the claims of creditors of the beneficial owners of the property transferred to the corporation; ${ }^{245}$ facilitation of management or conveyance of property owned by a group of investors; ${ }^{246}$ and concealment of the identity of the beneficial owners of property. $^{247}$

In the United States, beneficial owners of the property of straw corporations anticipate that courts will ignore the existence of the company, or will recognise its agency status in order to attribute income, gain or losses. If courts treat a straw corporation as a viable separate taxable entity, adverse tax consequence may occur. For instance, property dealings between the corporation and its shareholders may result in taxable gains or losses of holding periods, or income and losses from the property may be attributed to the corporation during the time it holds the property, and the shareholders may not be able to deduct those losses when they eventually receive the income.

In an effort to escape adverse tax consequences, taxpayers argue that courts should disregard the straw corporation for tax purposes on the basis that the corporation's activities are not sufficient to warrant its treatment as a separate taxable entity. ${ }^{248}$ Thus, in order to

\footnotetext{
244 For example Bruce L. Schlosberg v United States of America (1981) 81-1 USTC (CCH) P9272.

245 For example Moline Properties Inc $v$ Commissioner of Internal Revenue 319 Us 436 (1943).

${ }^{246}$ For example Roccaforte v. Commissioner of Internal Revenue 77 TC 263 (1981).

${ }^{247}$ For example Jones $v$ Commissioner of Internal Revenue $640 \mathrm{~F} 2 \mathrm{~d}$ 745 (5th Cir 1981).

${ }^{248}$ For example National Carbide Corp $v$ Commissioner of Internal Revenue 336 US 422 (1949). Taxpayers may accept the existence of the corporations as a separate tax entity, but argue that the straw corporation acts on their behalf as an agent.
} 
determine whether a straw corporation should be recognised as a separate taxable entity, courts investigate the nature of the corporation's activities. That is, courts apply the substantive business activity test.

\subsection{Difference between straw corporations cases and conduit company cases}

Both straw corporations and conduit companies pass on their income as legal owners to their shareholders, who are generally the beneficial owners. For this reason, the two situations may look similar at first glance. They involve, however, two very different issues.

In straw corporation cases, courts are aware that a straw corporation is not the beneficial owner of the company's property. The issue is, rather, whether a corporation exists as a taxable entity separate from its shareholder, so that the corporation can be regarded as the recipient of the income. In contrast, in conduit company cases, courts are not concerned with the separate entity of a corporation incorporated in a foreign jurisdiction. The issue is whether the corporation owns passive income beneficially.

Since in straw company cases courts apply the substantive business activity test to determine whether a corporation is the recipient of income, rather than whether a corporation is the beneficial owner, it could be inferred that they apply the test in a formal legalistic sense.

Courts in conduit company cases also decide in effect either to ignore or to recognise the existence of an intermediary corporation for tax purposes; however, this decision is a consequence of the application of the beneficial ownership test. In straw company cases, on the other hand, this decision is a result of the application of the substantive business activity test. 
Section 4.16 illustrates these arguments with the help of a comparison between Northern Indiana Public Service Company $v$ Commissioner of Internal Revenue ${ }^{249}$ and Moline Properties Inc $v$ Commissioner of Internal Revenue. $^{250}$

The point is that the presence of a substantive business activity may be sufficient to treat a corporation as a taxable entity separate from its shareholder; however, as explained in section 4.2, neither is substantive business activity an indicator of beneficial ownership, nor does its presence alone suggest that an intermediary is not acting as a mere conduit. That is why, although this test may be an appropriate determinant for straw company cases, it is in fact inappropriate for deciding conduit company cases.

\subsection{Base companies}

Base companies are predominantly situated in a low-tax or no-tax country, typically a tax haven. They are used for sheltering income that would otherwise accrue directly to the taxpayer, thereby reducing taxes in the taxpayer's home country. ${ }^{251}$ Although the main function of a base company is to avoid domestic tax law of the taxpayer's home country, a base company may also be employed for improper use of tax treaties. The taxpayer that establishes a base company for the improper use of a tax treaty in a contracting state may be the resident of the other

\footnotetext{
249 Northern Indiana Public Service Company $v$ Commissioner of Internal Revenue 105 TC 341 (1995).

${ }^{250}$ Moline Properties Inc v Commissioner of Internal Revenue 319 US 436 (1943).

${ }^{251}$ OECD Committee on Fiscal Affairs "Double Taxation Conventions and the Use of Base Companies" in OECD Committee on Fiscal Affairs International Tax Avoidance and Evasion: Four Related Studies, Issues in International Taxation No 1 (OECD, Paris, 1987) 60 at para 1.
} 
contracting state, ${ }^{252}$ or may be a resident of a third state. The consideration in the latter scheme is the treaty network of the tax haven country where the base company is located.

Although most tax havens have either a very limited treaty network or none at all, favourable treaties with major industrial countries do exist that allow domestic withholding tax rates to be reduced or eliminated. This partial or full exemption results in substantial tax savings. Taxation of this income is then avoided through a phenomenon called "secondary sheltering", ${ }^{253}$ which involves changing the character of the income to make use of the exemption provided for under tax treaties or domestic rules in the taxpayer's country of residence. The nature of the income can also be changed by the use of other techniques, such as "reploughing" the income by loans to the shareholder, or alienating a holding in the base company to realise the capital gain that may be exempted or taxed at a lower rate. ${ }^{254}$

A base company is able to shelter income from taxation in the resident state by virtue of the fact that it exists as a legal entity separate from the taxpayer. Thus, income that it collects no longer falls under the normal worldwide taxation regime of the resident state. The taxpayer,

${ }^{252}$ See the decision of the Bundesfinanzhof of 5 March 1986, IR 2001/82, published in the Official Tax Gazette, Part II, 1986 at 496. See also Rijkele Betten "Abuse of Law: Treaty Shopping through the Use of Base companies" (1986) ET 323.

253 OECD Committee on Fiscal Affairs "Tax Havens: Measures to Prevent Abuse by Taxpayers" in OECD Committee on Fiscal Affairs International Tax Avoidance and Evasion: Four Related Studies, Issues in International Taxation No 1 (OECD, Paris, 1987) 20 at para 27.

${ }^{254}$ Ibid. 
therefore, is not liable to pay tax in its home state on income received by the base company. ${ }^{255}$

\subsection{Why is substantive business activity a test for base company cases?}

In order to prevent tax avoidance through base companies, some countries have enacted controlled foreign company legislation. In addition, courts also apply general antiavoidance rules, or judicial anti-avoidance doctrines such as the abuse of law doctrine in civil law jurisdictions and the substance over form approach in common law states. Courts in the United States in particular have applied judicial doctrines such as the business purpose test and the sham transaction doctrine in order to decide base company cases. $^{256}$

As mentioned in section 4.10, a base company is able to shelter income from tax in the resident state because the base company is an entity in its own right and is recognised as such in the resident country. ${ }^{257}$ For this reason, taxpayers in base company cases are often taxed on the "piercing of the corporate veil" approach. ${ }^{258}$ Cases that involve the application of this approach turn on the issue of whether a base company can be disregarded for tax purposes so that its activity, or the income derived from the activity, may be attributed to the taxpayer. A taxpayer often claims that the income that the base company receives is derived with respect to a substantive business activity and, therefore, cannot be attributed to the taxpayer. Courts, therefore, ascertain the nature of the

\footnotetext{
${ }^{255}$ The Base Companies Report, above n 251, at para 10.

${ }^{256}$ See also Daniel Sandler Tax Treaties and Controlled Foreign Company Legislation: Pushing the Boundaries (Kluwer Law International, The Hague, 1998) at 8.

${ }^{257}$ The Base Companies Report, above n 251, at para10.

${ }^{258}$ See also ibid, at para 24.
} 
activities of the base company by applying the substantive business activity test. They attribute income of the base company to the taxpayer if they find that the activity of the base company is nothing more than simply receipt of passive income that would have directly accrued to the taxpayer.

\subsection{Difference between base company cases and conduit company cases}

Base company cases involving parties from more than two jurisdictions may appear to be similar to conduit company cases in two respects. First, the company structures are similar. Second, in both cases the income accrues in an economic sense to the taxpayer in the resident country. Therefore, courts in both cases effectively decide the question of whether the income of the intermediary can be attributed to the taxpayer. These similarities may well be the reasons why courts apply the substantive business activity test to conduit company cases.

Notwithstanding the apparent similarities, it is inappropriate to draw an analogy between base company and conduit company cases because there are subtle but crucial differences.

As mentioned in section 4.10, a base company seeks to minimise tax in the country of the residence of a taxpayer that is also its shareholder. It shelters income from the normal taxation of worldwide income in the taxpayer's residence state. In the process, it circumvents the domestic tax law of the residence state. For this reason, courts of the residence state decide a base company case in accordance with their domestic tax law. By contrast, a conduit company secures tax benefits in the country of the source of passive income. It minimises tax by improper use of the double tax treaty that limits the source state's right to 
impose withholding tax. That is why courts of the source state decide a conduit company case in accordance with treaty law.

Although courts adopt the substance over form approach for deciding both kinds of cases, treaty law functions in a different context from domestic tax law. Treaty law applies the beneficial ownership test in order to ensure that an intermediary that is a resident of a contracting state by virtue of its incorporation enjoys the passive income and does not pass it on to residents of a third state. That is, the beneficial ownership test operates with the object and purpose of limiting treaty benefits to residents of contracting states. However, the application of the substantive business activity test to base company cases does not have such an object and purpose.

Thus, although an intermediary that has a business activity can satisfy the substantive requirement of the domestic tax law applicable to a base company case, such an intermediary may not necessarily fulfil the object and purpose of a double tax treaty in a conduit company case. An intermediary that carries out substantive business activity may still act as a conduit to pass on passive income to the resident of a third state.

In other words, just because a base company case has been decided in favour of an intermediary on the basis of the company's business activity, it does not follow that a case that involves a conduit company that carries on a substantive business activity should also be decided in favour of the intermediary. That is, it is illogical to draw an analogy between base company cases and conduit company cases.

Nonetheless, courts have taken this quantum leap in conduit company cases. Northern Indiana Public Service 
Company $v$ Commissioner of Internal Revenue is a good example. $^{259}$

\subsection{Northern Indiana Public Service Company $v$ Commissioner of Internal Revenue}

The Northern Indiana case $^{260}$ involved Northern Indiana, a United States company that wished to raise funds on the Eurobond market. If Northern Indiana had borrowed funds directly from the Eurobond market, it would have to withhold United States withholding tax at the statutory rate on interest payments to the Eurobond holders. The interest payments minus the withholding tax would have made Northern Indiana's offer less attractive in the competitive Eurobond market.

Article VIII(1) of the United States-Netherlands double tax treaty of 29 April $1948,{ }^{261}$ which extended to the Netherlands Antilles, provided for a withholding tax exemption on United States sourced interest paid to corporations in the Netherlands Antilles. Moreover, the Netherlands Antilles charged no tax on interest, whether flowing inwards to residents, or out to non-residents.

Therefore, in order to avoid paying United States withholding tax, Northern Indiana established a wholly owned Antillean subsidiary, which will be referred to as Finance. Subsequently, Northern Indiana issued

\footnotetext{
259 Northern Indiana Public Service Company v Commissioner of Internal Revenue 105 TC 341 (1995). Northern Indiana Public Service Company v Commissioner of Internal Revenue 115 F 3d 506 (7th Cir 1997).

${ }^{260}$ Northern Indiana Public Service Company v Commissioner of Internal Revenue, above n 259.

261 Supplementary Convention Modifying and Supplementing the Convention with Respect to Taxes on Income and Certain other Taxes, United States-the Netherlands (30 December 1965, entered into force 8 July 1966). The relevant part of art VIII(1) provides: "Interest on bonds, notes, ... paid to a resident or corporation of one of the Contracting States shall be exempt from tax by the other Contracting State."
} 
Eurobonds through Finance. Finance borrowed money from Eurobond holders and on-lent the money to Northern Indiana. The interest rate at which Finance lent money to Northern Indiana was one percent higher than that at which Finance borrowed money from Eurobond holders. Consequently, Finance earned a profit, which it invested to produce more income. Northern Indiana liquidated Finance after it repaid the principal amount with the interest to Eurobond holders through Finance.

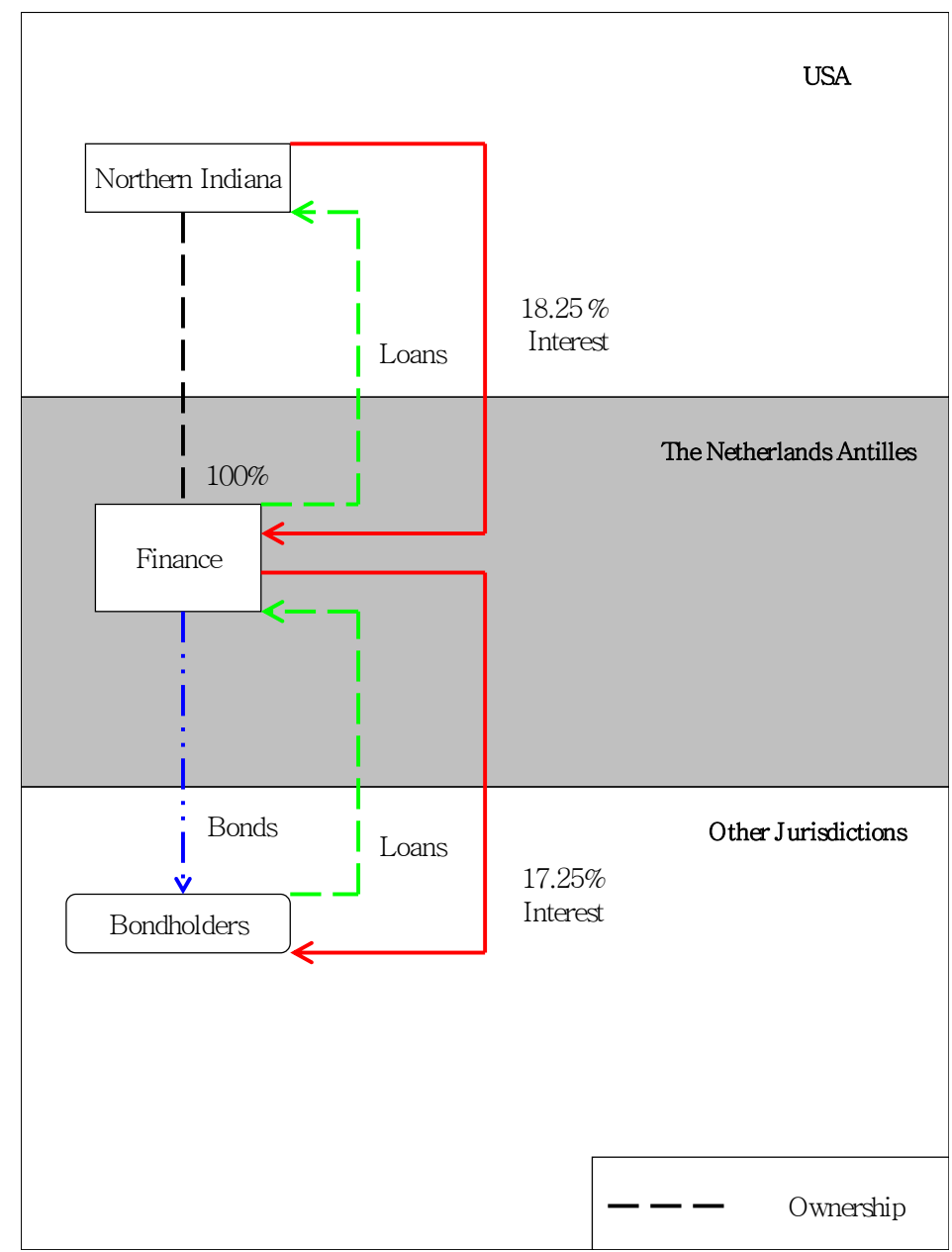

Figure 4.2: The Northern Indiana case

Northern Indiana did not deduct withholding tax from interest payments to Finance. The Commissioner issued a notice of deficiency to Northern Indiana, making it liable to pay the tax that it did not withhold. 
It was undisputed that Northern Indiana structured its transactions with Finance in order to obtain a withholding tax exemption under the United States-Netherlands double tax treaty. ${ }^{262}$ The Commissioner argued that Finance was a mere "conduit" or agent in the borrowing and interest paying process, and, therefore, Finance should be ignored for tax purposes, and Northern Indiana should be viewed as having paid interest directly to the Eurobond holders.

The United States Tax Court observed: "Normally, a choice to transact business in corporate form will be recognized for tax purposes so long as there is a business purpose or the corporation engages in business activity."263 According to the court, since Finance was involved in the business activity of borrowing and lending money at a profit, it should be recognised as the recipient of interest payments from Northern Indiana. ${ }^{264}$ The court, therefore, held that the interest payments were exempt from United States withholding tax. The Court of Appeals for the Seventh Circuit agreed with the Tax Court. It could be inferred that the Tax Court based its decision on the substantive business activity criterion.

\subsection{Northern Indiana: an illogical analogy}

The Tax Court considered substantive business activity as a sufficient criterion because it drew an analogy with straw company and base company cases that were decided on the basis of the substantive business activity test. It seemed to have confused the facts of the Northern Indiana case for the following two reasons.

\footnotetext{
262 Northern Indiana Public Service Company $v$ Commissioner of Internal Revenue 115 F 3d 506, 511 (7th Cir 1997).

263 Northern Indiana Public Service Company $v$ Commissioner of Internal Revenue $105 \mathrm{TC} 341(1995)$ at 347.

${ }^{264}$ Ibid, at 348.
} 
First, according to the Tax Court, similar to a straw company, Finance was created for a business purpose, namely "to borrow money in Europe and then lend money to [Northern Indiana] in order to comply with the requirements of prospective creditors". ${ }^{265}$ This similarity, however, did not alter the fact that Eurobond holders, rather than Northern Indiana, were the beneficial owners of the interest payments. Moreover, the case involved the application of the law of a double tax treaty, rather than the United States domestic tax law. The court, therefore, should have analysed the facts in the light of the object and purpose of a double tax agreement.

Second, as with a taxpayer in a base company scheme, Northern Indiana established a foreign subsidiary to avoid tax in the United States, the country of its residence. This similarity, however, did not change the fact that Northern Indiana was a source company and it interposed Finance to obtain a reduction of United States withholding tax under the United States-Netherlands double tax treaty on passive income that flowed out of the United States. Moreover, Eurobond holders, rather than Northern Indiana, were ultimately better off as the result of the being made interest payments without deduction of United States withholding tax. This argument applies even though Finance was not related to Eurobond holders. For this reason, the Northern Indiana case was a conduit company case and not a base company case.

As a result of drawing the analogy, the Tax Court analysed the facts within the wrong frame of reference. This point can be better illustrated by comparing the Northern Indiana case with some of the judgments

265 Ibid, at 354 . 
referred to by the court in the case. Moline Properties Inc $v$ Commissioner of Internal Revenue, ${ }^{266}$ a straw corporation case, and Hospital Corporation of America $v$ Commissioner of Internal Revenue, ${ }^{267}$ a base company case were two of those cases.

The following sections discuss Moline Properties and Hospital Corporation of America for the purpose of differentiating them from the Northern Indiana case. The discussion shows that substantive business activity cannot be considered to be a sufficient criterion for deciding conduit company cases.

\subsection{Moline Properties Inc v Commissioner of Internal Revenue}

In the Moline Properties case, ${ }^{268} \mathrm{Mr}$. Thompson mortgaged his property to borrow money to make an investment. The investment proved unprofitable. Thompson's creditors advised him to incorporate Moline Properties Inc, which will be referred to as Moline, in order to serve as a security device for the property. $\mathrm{He}$ conveyed the property to Moline in return for all of its shares. Moline also assumed the outstanding mortgage. Thompson then transferred the shares as collateral to a trust controlled by his creditors.

Until Thompson repaid the original loans, Moline's activity consisted of assuming one of Thompson's obligations to the original creditors, defending Moline's proceedings, and instituting a suit to remove prior restrictions on the property. After Thompson satisfied the

\footnotetext{
${ }^{266}$ Moline Properties Inc v Commissioner of Internal Revenue 319 US 436 (1943).

267 Hospital Corporation of America $v$ Commissioner of Internal Revenue 81 TC 520 (1983).

${ }^{268}$ Moline Properties Inc v Commissioner of Internal Revenue, above n 266, at 436 .
} 
mortgage and gained control over Moline, Moline entered into several transactions involving the property, which included mortgaging, leasing and finally selling the property. Moline kept no books and maintained no bank account. Thompson received the proceeds from the sale, which he deposited into his bank account. Although initially Moline reported the gain on sale of the property on its income tax return, Thompson filed a claim for a refund on Moline's behalf and reported the gain on his individual tax return.

The issue before the United States Supreme Court was whether the gain from the sale was attributable to Moline. In order to answer the question, the court considered whether Moline should be disregarded for tax purposes. The court observed: ${ }^{269}$

\begin{abstract}
The doctrine of corporate entity fills a useful purpose in business life. Whether the purpose be to gain an advantage under the law of the state of incorporation or to avoid or to comply with the demands of creditors or to serve the creator's personal or undisclosed convenience, so long as that purpose is the equivalent of business activity or is followed by the carrying on of business by the corporation, the corporation remains a separate taxable entity.
\end{abstract}

According to the court, Moline's activities were sufficient to recognise it as a taxable entity separate from Thompson. Based on this opinion, it attributed the gain on sales to Moline.

\title{
4.16. Difference between Northern Indiana and Moline Properties
}

It is hard to rely logically on Moline Properties for deciding Northern Indiana on the basis of the substantive business activity test. The court in Moline Properties was aware that Mr. Thompson was the beneficial owner of the

\footnotetext{
${ }^{269}$ Moline Properties Inc $v$ Commissioner of Internal Revenue, above
} n 266, at 438 . 
property and of the income from the sale of the property. It was concerned with the issue of whether Moline received the income as a taxable entity separate from Thompson. The presence of business activity, therefore, was sufficient to ascertain that Moline existed as a separate taxable entity. By contrast, in Northern Indiana, it was clear that Finance was the recipient of the interest payments. The issue in Northern Indiana should have been whether Finance was the beneficial owner of the interest and was therefore entitled to treaty benefits, or whether Finance was acting as a mere conduit. Nevertheless, the conclusion of the Tax Court in Northern Indiana shows that it focused on the issue of whether Finance was conducting the business of receiving and paying interest payments. ${ }^{270}$

Northern Indiana dealt with Article VIII(1) of the United States-Netherlands double tax treaty. Although the provision did not use the term "beneficial owner", ${ }^{271}$ the focal issue should have been whether Finance was the substantive economic owner of the interest payments. That is, although the context of the double tax treaty required the court to interpret the provision from a substantive economic perspective, the court in fact interpreted it in a formal legalistic sense.

The Tax Court observed: "Moline Properties, Inc. v. Commissioner ... stands for the general proposition that a choice to do business in corporate form will result in

270 Northern Indiana Public Service Company $v$ Commissioner of Internal Revenue, above n 263, at 348.

271 Supplementary Convention Modifying and Supplementing the Convention with Respect to Taxes on Income and Certain other Taxes (30 December 1965, entered into force 8 July 1966). The relevant part of art VIII(1) provides: "Interest on bonds, notes, ... paid to a resident or corporation of one of the Contracting States shall be exempt from tax by the other Contracting State." 
taxing business profits at the corporate level." ${ }^{272}$ As discussed in section 2.15, according to the legal perspective income tax should be levied at the level of the corporation and not at the level of shareholders. The foregoing observation confirms that the court in Northern Indiana interpreted the treaty provision and analysed the facts in a formal legalistic sense because it drew an analogy with straw company cases.

\subsection{Hospital Corporation of America v Commissioner of Internal Revenue ${ }^{273}$}

As mentioned in section 4.14, the Tax Court in Northern Indiana also referred to Hospital Corporation of America, a base company case. In this case, the Hospital Corporation of America, which will be referred to as Hospital Corporation, entered into a management contract with King Faisal Specialist Hospital in Saudi Arabia. Hospital Corporation established the following corporate structure.

Hospital Corporation incorporated Hospital Corp International Ltd, a wholly owned subsidiary, in the Cayman Islands. Hospital Corp International Ltd held all the shares in Hospital Corporation of the Middle East Ltd, which will be referred to as Middle East Ltd, also a resident in the Cayman Islands. Middle East Ltd and Hospital Corporation had the same officers and directors. Middle East Ltd did not have its own office. It shared the office address of a law firm that prepared its incorporation documents. Hospital Corporation decided to administer

\footnotetext{
272 Northern Indiana Public Service Company $v$ Commissioner of Internal Revenue, above n 270, at 351.

273 Hospital Corporation of America $v$ Commissioner of Internal Revenue, above n 267.
} 
the management contract through Middle East Ltd, which then acted as a base company.

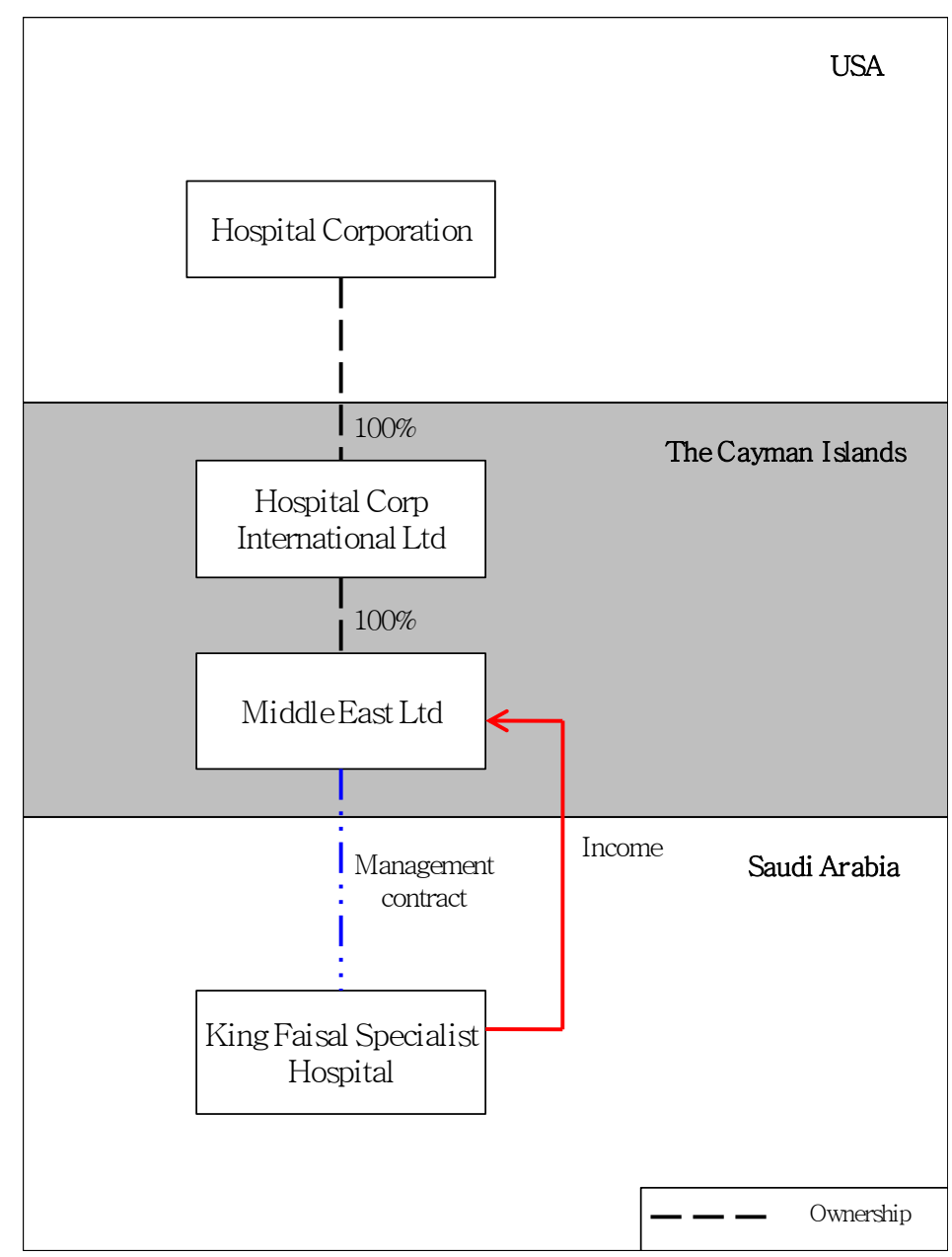

Figure 4.3: The Hospital Corporation of America case

The issues before the court were whether Middle East Ltd was a sham corporation that should not be recognised for tax purposes, and whether its income was attributable to Hospital Corporation under section 482 of the Internal Revenue Code. $^{274}$

${ }^{274}$ Internal Revenue Code 26 USC $\S 482$. It provides that the Secretary of the Treasury may allocate gross income, deductions and credits between or among two or more taxpayers owned or controlled by the same interests in order to prevent evasion of taxes or clearly reflect income of a controlled taxpayer. 
The United States Tax Court found that Middle East Ltd "carried out some minimal amount of business activity". ${ }^{275}$ The court observed: ${ }^{276}$

[Middle East Ltd] possessed the "salient features of corporate organization."... [Middle East Ltd] was properly organized under the Companies Law of the Cayman Islands. In 1973, [Middle East Ltd] issued stock, elected directors and officers, had regular and special meetings of directors, had meetings of shareholders, maintained bank accounts and invested funds, had at least one non-officer employee, paid some expenses, and, with substantial assistance from [Hospital Corporation], prepared in 1973 to perform and in subsequent years did perform the [King Faisal Specialist Hospital] management contract. All of these are indicative of business activity.

The court was of the opinion that the quantum of business activity needed for a company to be recognised as a separate taxable entity "may be rather minimal". ${ }^{277}$ It held, therefore, that Middle East Ltd was not a sham corporation and had to be recognised for the purpose of Federal income tax. However, the court held that 75 per cent of the net income of Middle East Ltd was allocable to Hospital Corporation because Hospital Corporation performed substantial services for Middle East Ltd without being paid.

\subsection{Difference between Northern Indiana and Hospital Corporation of America}

It does not make sense to rely on the reasoning of the Hospital Corporation of America case for deciding Northern Indiana. In Hospital Corporation of America, the court used the substantive business activity criterion to determine whether Middle East Ltd existed as a sham, or whether the company should be recognised as a separate

\footnotetext{
${ }^{275}$ Hospital Corporation of America v Commissioner of Internal Revenue above n 267, at 584.

${ }^{276}$ Hospital Corporation of America v Commissioner of Internal Revenue above n 267, at 584.

${ }^{277}$ Ibid, at 579 .
} 
entity for tax purposes. The activities that the court considered to be business activities seemed nothing more than those that necessarily preserve the existence of a corporation. The court was primarily concerned with the existence of Middle East Ltd as a separate taxable entity. For this reason, a minimal amount of activity was sufficient to satisfy the substantive requirement. By contrast, in Northern Indiana, the issue was whether Finance received income in principle on its own behalf, or whether it functioned as a mere conduit.

Unlike Northern Indiana, Hospital Corporation of America did not concern a double tax treaty, and therefore, was not decided in the context of the object and purpose of a double tax treaty. The court in Hospital Corporation of America applied the sham transaction doctrine in the context of the United States domestic tax law and found that the presence of business activity indicated sufficiently that Middle East Ltd was not a sham. On the other hand, Northern Indiana concerned the United StatesNetherlands double tax treaty and should have been decided in the context of the object and purpose of that treaty. The fact that Finance had a business activity did not necessarily show that the arrangement was not contrary to the object and purpose of the treaty. Regardless of whether Finance was engaged in substantive business activity, it was undisputed that Northern Indiana located Finance in the Netherlands Antilles in order to obtain treaty benefits. The application of the sham transaction doctrine cannot be equated to the application of the beneficial ownership test, even if it deploys the substance over form approach. Nevertheless, in Northern Indiana, the Court of Appeal for the Seventh Circuit in particular used the words "conduit" and "sham" interchangeably with reference to Hospital 
Corporation of America. ${ }^{278}$ Thus, the reasoning of the courts in Northern Indiana was erroneous and misleading.

A related point that emerges is that the substantive business activity test logically should work as a one-way test in conduit company cases. That is, the absence of business activity may establish that the interposition of an intermediary lacks substance; however, the fact that an interposed company has business activity does not necessarily show that the interposed company is not a conduit. This argument can further be illustrated by referring to the reasoning of the Bundesfinanzhof in decisions concerning section 50(3) of the German Income Tax Act, ${ }^{279}$ as it stood before 19 December 2006.

Section 50d(3) deals with conduit company situations; however, as with the courts in Northern Indiana, the German legislature has transposed the substantive business activity test from base company cases to conduit company cases. For this reason, the application of section $50 \mathrm{~d}(3)$ resulted in inconsistent decisions in similar sets of facts before the amendment of December 2006.

\subsection{Section 50d(3) of the German Income Tax Act}

Section 50d of the German Income Tax Act, abbreviated as EStG, deals with cases of the reduction of capital gains tax and withholding tax under German double tax agreements. Section $50 \mathrm{~d}(3)$ of the EStG is a countermeasure against the abuse of treaties and the abuse of the Parent-Subsidiary Directive of the Council of the

\footnotetext{
278 Northern Indiana Public Service Company $v$ Commissioner of Internal Revenue (1997) 115 F 3d 506, 510 (7th Cir).

${ }^{279}$ Einkommensteuergesetz [EStG] [Income Tax Act], 16 October 1934 RGBl I at 1005, § 50d, ๆ 3 .
} 
European Communities. $^{280}$ The German legislature introduced section $50 \mathrm{~d}(3)$ of the EStG in 1994. Section $50 \mathrm{~d}(3)$, before its amendment in December $2006,{ }^{281}$ read (author's translation): ${ }^{282}$

A foreign company is not entitled to a full or partial relief under sections 1 and 2 if and to the extent persons with a holding in it are not entitled to reimbursement or exemption had they received income directly and if there is no economic or other relevant reasons for interposing the foreign company and the foreign company does not have a economic activity of its own.

Although the wording of the provision does not show expressly that it is restricted to dividends and withholding tax, it could be inferred that the provision also deals with conduit company situations. ${ }^{283}$ Further, sections 4.22 and 4.24 will illustrate with the help of cases that the term "economic activity" signifies substantive business activity.

Section $50 \mathrm{~d}(3)$ of the EStG constitutes a special antiavoidance rule. It operates as a supplement to section 42 of the German General Tax Code, ${ }^{284}$ abbreviated as AO, which is the German general anti-avoidance rule. In the wording of the provision, the legislature relied heavily on

280 Directive 90/435/EEC on the Common System of Taxation Applicable in the Case of Parent Companies and Subsidiaries of Different Member States [1990] OJ L 225/0006.

${ }^{281}$ Einkommensteuergesetz [EStG] [Income Tax Act], 16 October 1934 BGBl I at 3366 as amended by Jahressteuergesetzes [Finance Law], 13 December 2006 BGBl I at 2878, § 50d, $₫ 3$.

282 The German Income Tax Act, Above n 279, § 50d, ๆ 3 .

283 See Rolf Füger and Norbert Rieger "German Anti-Avoidance Rules and Tax Planning of Non-Resident Taxpayers" (2000) 54 Bulletin of International Bureau of Fiscal Documentation 434 at 441. See also Wilhelm Haarmann and Christoph Knödler "German Supreme Tax Court Limits the Scope of the German Anti-Treaty Shopping Rule and Redefines Substance Requirement for Foreign Companies (2006) 34 Intertax 260 at 260.

${ }^{284}$ Abgabenordnung [AO] [The General Tax Code] 16 March 1976, BGBl I at 3366, as amended, $\S 42$. According to $\S 42$, the legal effects of provisions of the tax code may not be avoided by abusive behaviour on the part of the taxpayer. In the event of such behaviour, tax will be imposed as if the taxpayer had structured the situation using the appropriate form. 
the principle developed in the context of section 42 of the AO by case law on the use of foreign base companies by German residents. ${ }^{285}$ That is, as with the United States courts, the German legislature has also borrowed the economic activity test from base company cases. As a result, when interpreting and applying section $50 \mathrm{~d}(3)$, the Bundesfinanzhof has drawn an analogy with base company cases. A good example is the decision of the Bundesfinanzhof of 20 March 2002, ${ }^{286}$ which will be referred to as G-group 2002.

Section 50d(3), as it stood before December 2006, was worded in the negative. That is, it provided for conditions where a conduit company is not entitled to a reduction of German withholding tax. In its decision of 31 May $2005,{ }^{287}$ which will be referred to as the G-group 2005, the Bundesfinanzhof held that in order to deny tax relief, the facts of a case should show that economic or other valid reasons for the interposition of a corporation and economic activity of the corporation were absent at the same time. That is, the court considered the conditions to be cumulative, in order to refuse treaty benefits.

In the context of conduit company cases, the cumulative existence of the conditions should not necessarily imply that the presence of an economic activity qualifies a company for tax relief. However, since the Bundesfinanzhof relied on the reasoning of base company cases, it regarded the conditions to be alternative in order to allow tax relief under section $50 \mathrm{~d}(3){ }^{288} \mathrm{In}$

\footnotetext{
${ }^{285}$ See Füger and Rieger, above $\mathrm{n} 283$ at 440.

${ }^{286}$ Re a Corporation (2002) 5 ITLR 589 (The Bundesfinanzhof, Germany).

287 G-group 2005 (31 May 2005) IR 74, 88/04, para 27 (The Bundesfinanzhof, Germany).

${ }^{288}$ Ibid, at para 31(bb).
} 
effect, it regarded economic activity as a sufficient criterion.

G-group 2002 and G-group 2005 concerned the same group of companies. The two cases had similar facts and the same issues; however, since the Bundesfinanzhof relied on the reasoning of base company cases, it came to different conclusions. The following sections analyse the cases.

\subsection{The G-group 2002 case}

The G-group 2002 case $^{289}$ concerned the G-group of companies, which was involved in the television sector. The corporate structure of the G-group was as follows. Mr. E, a resident of Bermuda, was 85 per cent shareholder in G Ltd, a Bermudan corporation. Mr. B, a resident of the United States, and Mr. H, a resident of Australia, each held 7.5 per cent shares. G Ltd in turn owned Dutch BV, a company incorporated in the Netherlands. Dutch BV was the taxpayer. It used the business premises and other office equipment of another Dutch member of the G-group. Dutch BV held all the shares in $\mathrm{GmbH}$, a German corporation.

${ }^{289}$ Re a Corporation, above n 286. 


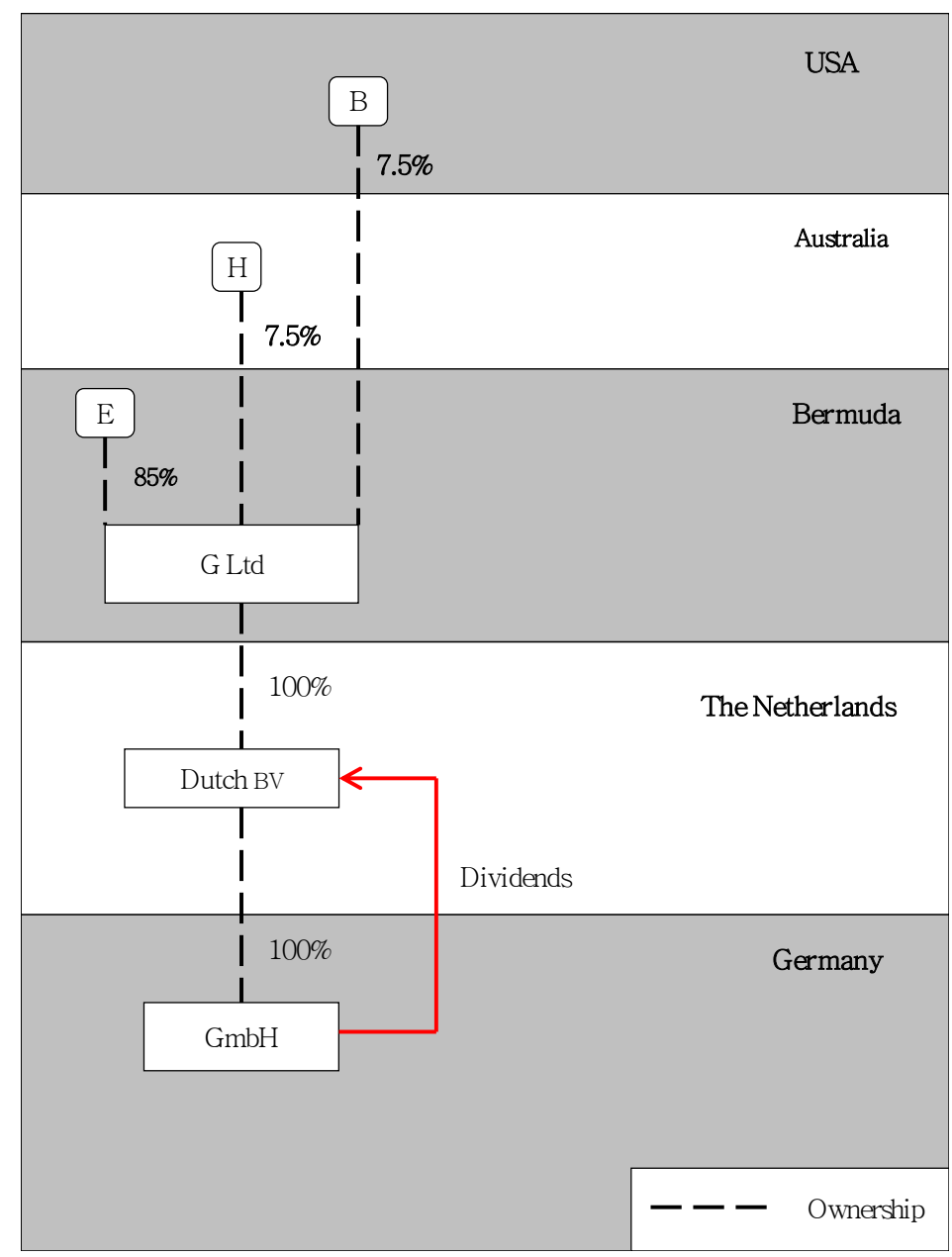

Figure 4.4: G-group 2002

$\mathrm{GmbH}$ paid dividends to Dutch $\mathrm{BV}$ and deducted withholding tax from the payment. Dutch BV claimed a refund of German withholding tax under the GermanNetherlands double tax treaty of 16 June $1959 .^{290}$ The German tax authority granted a partial reimbursement corresponding to the participation of $\mathrm{Mr}$. $\mathrm{H}$ and $\mathrm{Mr}$. B in G Ltd in accordance with the respective German double tax treaties with Australia and the United States. The tax authority, however, denied any further reimbursement on the basis that Mr. E, who was the majority shareholder, was a resident of Bermuda, which does not have a double

${ }^{290}$ Convention for the Avoidance of Double Taxation with respect to Taxes on Income and Capital and Various other Taxes, and for the Regulation of other Questions relating to Taxation, Germany-the Netherlands (16 June 1959, entered into force 18 September 1960). 
tax treaty with Germany. The matter went before the

Bundesfinanzhof.

The Bundesfinanzhof held that, because Dutch BV was

"a base company without real economic function", ${ }^{291}$ the withholding tax relief could be refused under section $50 \mathrm{~d}(3)$ of the EStG, ${ }^{292}$ as well as under section 42 of the AO. Although G-group 2002 involved a conduit company scheme, the court referred to Dutch BV as a base company.

\subsection{G-group 2002: another analogy with base company cases}

The Bundesfinanzhof was of the opinion that section $50 \mathrm{~d}(3)$ had similar requirements and, therefore, a similar aim to that of section 42 of the $\mathrm{AO}^{293}$ Although the language of section $50 \mathrm{~d}(3)$ clearly showed that the provision applied to conduit company cases, when interpreting the provision the court drew an analogy with base company cases. It observed: ${ }^{294}$
According to the jurisprudence of the [Bundesfinanzhof] ..., intermediary base companies in the legal form of a corporation in a low tax regime country fulfil the elements of abuse if economic or otherwise acceptable reasons are missing. If income received in Germany is 'passed through' a foreign corporation, this is also true if the state of residence of the foreign corporation is not a low tax regime ... . The court accepts as a principle that tax law respects the civil law construction. But there must be an exception for such constructions possessing only the aim of manipulation.

Although it was clear from the facts of the case that it involved the taxation of out-going income that originated in Germany, the court referred to a situation of income flowing into Germany. It used phrases such as

\footnotetext{
${ }^{291}$ Re a Corporation, above n 286, at 599 (emphasis added).

${ }^{292} \S 50 \mathrm{~d}$, \ 3 of the EStG was $\S 50 \mathrm{~d}$, \ 1a EStG at the time of the decision.

${ }^{293}$ Re a Corporation, above n 286, at 599.

${ }^{294}$ Ibid, at 600 (emphasis added).
} 
"intermediary ... in the legal form of corporation", "tax law respects the civil law construction", and "exception for such constructions". The words suggest that the court was preoccupied with the issue of when the separate entity of an intermediary could be ignored for tax purposes. As discussed in section 4.19, the German legislature's reliance on base company cases in drafting section $50 \mathrm{~d}(3)$ seems to be a reason for the court's approach.

\title{
4.22. Is business activity a conclusive criterion for deciding conduit company cases?
}

In G-group 2002, the Bundesfinanzhof noted that Dutch BV had no employees, premises or office equipment. The court also considered the fact that the director of Dutch BV was serving as the director of other affiliated companies. It did not accept the contention of Dutch BV that its interposition was for reasons of organisation and coordination, establishment of customer relationships, costs, local preferences, and the conception of the enterprise. It observed: ${ }^{295}$

\begin{abstract}
All these aspects make plain the background of the construction of the G-group, they make plain why and how European engagement of the group was concentrated within the Netherlands. But they cannot explain convincingly and justify why the foundation of [Dutch BV] as a letterbox corporation without economic or otherwise acceptable grounds was necessary.
\end{abstract}

The court was not convinced that Dutch BV had developed its own economic activity. ${ }^{296}$ It held that Dutch BV's participation in $\mathrm{GmbH}$ without any managing function did not fulfil the requirement of economic activity under the provision.

Although the Bundesfinanzhof came to a correct conclusion, its logic did not make sense. The problem with

\footnotetext{
${ }^{295}$ Re a Corporation, above n 286, at 601.

296 Ibid, at 601.
} 
the judgment is that the court analysed the facts in the light of the reasoning of base company cases, rather than in the context of the object and purpose of the GermanyNetherlands double tax agreement. Because of the analogy with base company cases, the decision implied that presence of economic activity would have been sufficient under section $50 \mathrm{~d}(3)$ to allow treaty benefits. The judgment in G-group 2002 does not express this implication because the court found that activities of Dutch BV did not constitute "economic activity" under section $50 \mathrm{~d}(3)$. The inference from G-group 2002, however, becomes explicit when the same group returns to the Bundesfinanzhof in G-group 2005. ${ }^{297}$

\subsection{The G-group 2005 case}

$G$-group 2005 concerned the same group of companies that was involved in G-group 2002. The corporate structure in G-group 2005, however, was slightly different. In G-group 2005, G Ltd wholly owned NV, a subsidiary incorporated in the Netherlands Antilles. In addition, G Ltd wholly owned other Dutch, European and non-European subsidiaries. NV, in turn, wholly owned two Dutch subsidiaries.

The main difference between G-group 2002 and $G$ group 2005 was that in G-group 2005, each Dutch subsidiary also held shares in other European and nonEuropean corporations in addition to shares in a German company. One of these Dutch subsidiaries also held shares in another Dutch company. As in the G-group 2002 case, the Dutch subsidiaries in G-group 2005 had no employees, business premises or equipment. Each Dutch subsidiary used the facilities of another affiliated Dutch company.

\footnotetext{
${ }^{297}$ G-group 2005 (31 May 2005) IR 74, 88/04 (The Bundesfinanzhof,
} Germany) 
The German companies paid dividends to the Dutch subsidiaries and deducted withholding tax.

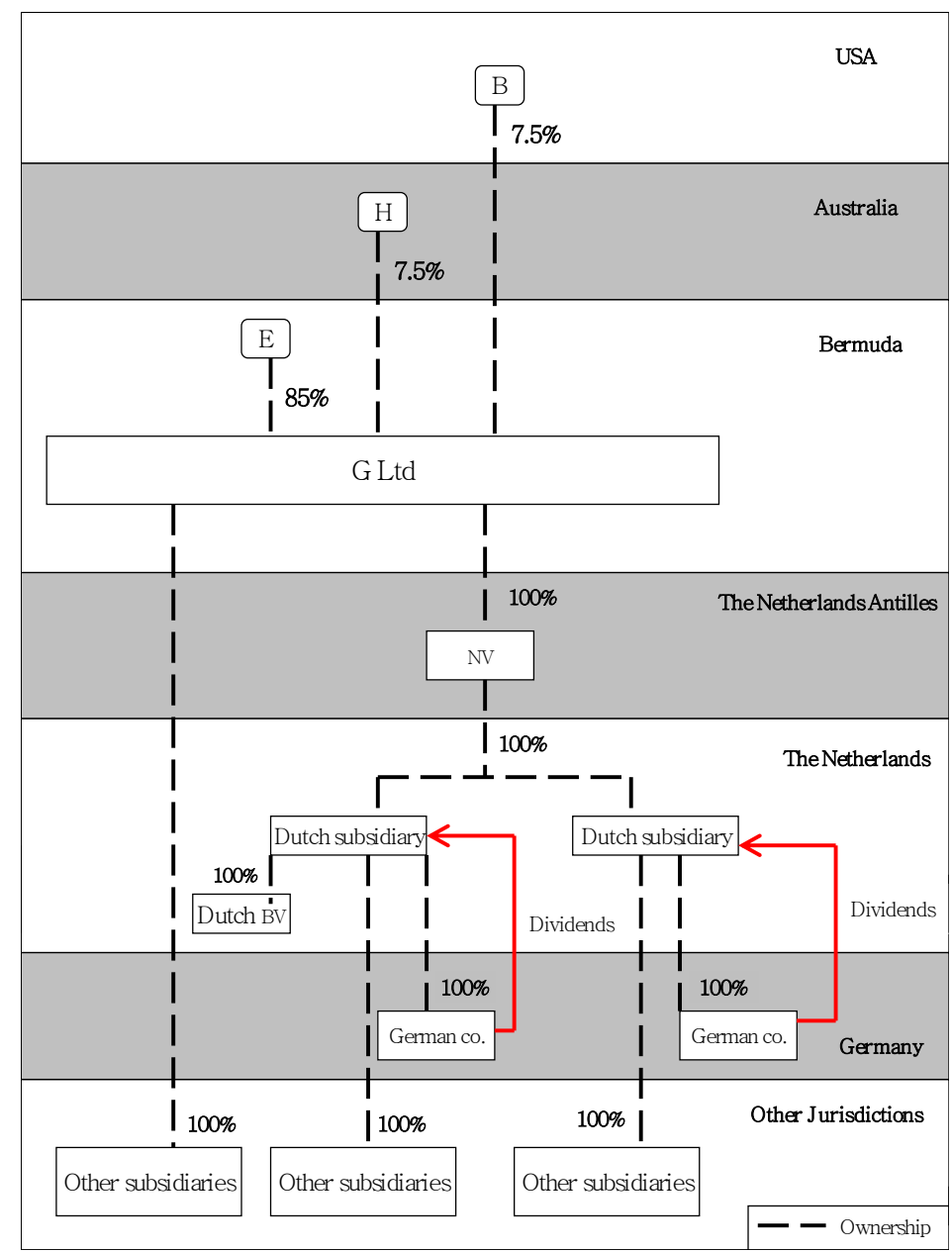

Figure 4.5: G-group 2005

As with G-group 2002, the German tax authority in $G$ group 2005 granted a partial reimbursement with respect to the participation of $\mathrm{Mr} . \mathrm{H}$ and $\mathrm{Mr}$. B, who were residents of Australia and the United States respectively, and denied a reimbursement to Mr. E, who was a Bermudan resident. The Bundesfinanzhof, however, allowed the refund under section $50 \mathrm{~d}(3)$ of the EStG.

The court found that neither of the two conditions under section $50 \mathrm{~d}(3)$ was applicable. That is, according to the court, there were economic and other relevant reasons 
for the interposition of the Dutch subsidiaries, and they were involved in economic activities of their own.

\subsection{Interpretation of section $50(d)$ in the light of base company cases}

As with G-group 2002, in G-group 2005 the

Bundesfinanzhof based its reasoning on base company cases. When interpreting section $50 \mathrm{~d}(3)$, the court observed (author's translation): ${ }^{298}$

[Section $50 \mathrm{~d}(3)$ of the EStG] excludes the right of a foreign corporation to be tax exempted or to pay a lower tax ... according to a double taxation convention, if persons participating in that corporation would have no right to a reduction of tax had they received the dividends directly, and-first-there is no economic or otherwise valid reasons for the interposition of the corporation and-second-the corporation does not have an economic activity of its own. The latter two requirements are cumulative for the tax relief to fail.

It is clear that the court was of the opinion that the facts of a case should satisfy both conditions at the same time, in order to refuse withholding tax reduction under section $50 \mathrm{~d}(3)$.

The Bundesfinanzhof noted that the Dutch subsidiaries were a part of the G-group along with European and nonEuropean affiliates engaged in active business. ${ }^{299}$ In the Ggroup, the Dutch subsidiary had the function of holding the shares of some of these affiliates including the German companies. The court regarded the simple holding of shares as economic activity. ${ }^{300}$

According to the Bundesfinanzhof, all affiliates outsourced the holding of shares within the group to independent corporations, such as the Dutch subsidiaries. It found that this strategic outsourcing was a long-term activity and therefore concluded that, in the present case,

\footnotetext{
${ }^{298}$ G-group 2005, above n 297, at para 27.

${ }^{299}$ Ibid, at para 30(aa).

${ }^{300} \mathrm{Ibid}$, at para 32.
} 
the activity could not be considered to exist for the purpose of obtaining a withholding tax refund under the Germany-Netherlands double tax treaty. It noted that the Netherlands was the centre of the business of the European corporations of the G-group. Thus, the Dutch subsidiaries were located in the Netherlands not solely for the purpose of obtaining treaty benefits. The court, therefore, was of the opinion that the Dutch subsidiaries were entitled to treaty benefits by virtue of being residents of the Netherlands. ${ }^{301}$

Based on these findings the Bundesfinanzhof concluded (author's translation): ${ }^{302}$

... [The Dutch subsidiaries] fulfilled their business purpose - holding of shares in foreign corporations - on their own account and autonomously. That is, the interposition of the Dutch subsidiaries had economic or other valid reasons. The absence of such reasons, however, is essential to deny a tax relief under [section $50 \mathrm{~d}(3)$ of the EStG]. Since [section $50 \mathrm{~d}(3)$ of the EStG] expressly refers to the (alternative) requirement of economic and other valid reasons, it is a special rule for abuse of law as compared to [section 42 of the AO], and may also be applied conclusively without reference to [section 42 of the AO].

Two points emerge. First, the Bundesfinanzhof considered the absence of economic or other valid reasons to be an essential requirement, when it referred to section $50 \mathrm{~d}(3)$ in terms of refusing the tax relief. It considered, however, the presence of economic or other valid reasons to be an alternative requirement when it seemed to refer to section $50 \mathrm{~d}(3)$ in terms of allowing treaty benefits. It could be inferred that in order to allow treaty benefits, the presence of economic activity was the alternative requirement. That is, effectively the court considered economic activity to be a sufficient criterion to allow treaty relief.

\footnotetext{
301 G-group 2005, above n 297, at para 31(bb).

302 Ibid, at para 31(bb) (emphasis added).
} 
Second, the court equated the presence of "economic or other valid reasons" with business purpose. In this respect, the reasoning of the Bundesfinanzhof resembles the reasoning of the United States Tax Court in the Northern Indiana case, ${ }^{303}$ where the court drew an analogy with base company cases and was of the opinion that a withholding tax reduction was available "so long as there is a business purpose or the corporation engages in business activity". ${ }^{304}$ It follows that, as with the court in Northern Indiana, the Bundesfinanzhof decided the case using the wrong frame of reference.

Further, the holding of shares of affiliates seems to be a weak form of economic activity. Even if it were economic activity, there were arguably no strong economic and other relevant reasons for interposing the Dutch subsidiaries. The considerations that the Bundesfinanzhof regarded as "economic and other relevant reasons" for their interposition seemed to be reasons for the organisation and co-ordination of the G-group. ${ }^{305}$ In sharp contrast, the court in G-group 2002 rejected such reasons on the basis that they merely clarified the corporate structure and business engagements. ${ }^{306}$

The analysis of G-group 2002 and G-group 2005 confirms that when applying the substantive business activity test, courts draw an analogy with base company cases. As a result, they decide conduit company cases erroneously, treating business activity as a sufficient criterion.

\footnotetext{
303 Northern Indiana Public Service Company $v$ Commissioner of Internal Revenue 105 TC 341 (1995).

304 Ibid, at 347 (emphasis added).

${ }^{305}$ Ibid, at 347.

${ }^{306}$ Re a Corporation, above n 286, at 601 .
} 
It seems, however, illogical to base the decision in a conduit company case on business activity. The discussion so far has shown that business activity works as a one-way test in conduit company cases. For instance, judgments in G-group 2002 and the $A$ Holding case ${ }^{307}$ show that the absence of business activity establishes that the interposition of a company lacks substance and, therefore, the company can be categorised as a conduit. However, judgments in G-group 2005 and the Northern Indiana case $^{308}$ fail to show convincingly that the presence of business activity necessarily indicates that the intermediary company does not act as a conduit.

\subsection{What constitutes substantive business activity?}

Since courts have applied the substantive business activity test with reference to base company cases, they have accorded such importance to the substantive business activity criterion that they seem to recognise mere holding of shares and management of passive income as substantive business activity. In some of the previous decisions, courts have determined that activities of the intermediaries had a business purpose. However, on examining these activities in the context of conduit company cases, it appears evident that the taxpayer's arrangement had no real purpose apart from obtaining treaty benefits improperly.

The following sections will illustrate the argument by investigating the activities that the courts have recognised as substantive business activities. The analysis is relevant

${ }^{307}$ A Holding ApS v Federal Tax Administration (2005) 8 ITLR 536 (The Federal Court, Switzerland).

308 Northern Indiana Public Service Company $v$ Commissioner of Internal Revenue 105 TC 341 (1995). Northern Indiana Public Service Company v Commissioner of Internal Revenue 115 F 3d 506 (7th Cir 1997) at 510. 
because, although substantive business activity cannot be considered a determinant in conduit company cases, it can be treated as one of the criteria for determining reasons for the existence of an interposed company in a specific corporate structure.

\subsection{Does profit spread indicate business activity?}

As discussed in section 4.13, in the Northern Indiana case $^{309}$ there was a spread of one per cent between Finance's inward and outward interest rates. This spread yielded a profit to Finance, which it invested to produce more income. According to the United States Court of Appeals for the Seventh Circuit, these facts showed that the transactions carried on by Finance had economic substance. Thus, the court recognised Finance's activity of borrowing and lending money as meaningful business activity.

The United States courts have used, what is known as "the two-prong test", in order to determine the economic substance of a transaction. Applying the test, they have examined the economic substance of a transaction against two thresholds. First, a court must find that the taxpayer subjectively had a non-tax purpose for the transaction. That is, a transaction should be related to a useful non-tax business purpose that is plausible in the light of the taxpayer's conduct and economic situation. ${ }^{310}$ Second, there must be an objective showing of a realistic possibility of a pre-tax profit. That is, the transaction must result in a meaningful and appreciable enhancement in the net economic position of the taxpayer (other than to

\footnotetext{
309 Northern Indiana Public Service Company $v$ Commissioner of Internal Revenue 115 F 3d 506 (7th Cir 1997).

${ }^{310}$ For example James A Shriver $v$ Commissioner of Internal Revenue 899 F $2 d 724$ ( $8^{\text {th }}$ Cir 1990).
} 
reduce its tax). ${ }^{311}$ There is no uniform manner of the application of the test. ${ }^{312}$

As discussed in section 4.14, in Northern Indiana the United States Tax Court found that Finance was established for a business purpose. Regardless of the manner of the application of "the two-prong test", it could be inferred that the United States Court of Appeals referred to the second threshold when it considered the profit spread. It observed: ${ }^{313}$

Here, a profit motive existed from the start. Each time an interest transaction occurred, Finance made money and [Northern Indiana] lost money. Moreover, Finance reinvested the annual ... interest income it netted on the spread in order to generate additional interest income, and none of the profits from these reinvestments are related to [Northern Indiana].

Finance's activity to earn a profit on the inward and outward interest flows corresponded to a conventional reinvoicing transaction, which is generally regarded as tax avoidance. Reinvoicing involves back-to-back transactions that manipulate prices to inflate deductions. The reinvoicing technique is usually used for buying and selling transactions, typically for exporting or importing. It involves three parties: a corporation that owns a business; an intermediary that can be located either in a foreign lowtax jurisdiction ${ }^{314}$ or in the country of the business

${ }^{311}$ Knetsch v United States 364 US 361 (1960).

312 Courts have applied the two-prong test disjunctively and subjunctively. Some courts have not used the two-prong test. These courts have viewed business purpose and economic substance as mere factors to determine the issue of whether the transaction had any practical economic effect rather than the creation of some tax benefits. See Transcapital Leasing Assocs 1990-II LP v United States 97 AFTR 2d 2006-1916 (2006).

313 Northern Indiana Public Service Company $v$ Commissioner of Internal Revenue, above n 309, at 514 (emphasis added).

${ }^{314}$ For example HIE Holdings Inc v Commissioner of Internal Revenue TC Memo 2009-130. 
owner; ${ }^{315}$ and customers. Although the intermediary is often an affiliate of the business owner, in some situations the business owner uses disguised ownership.

Reinvoicing is considered a tax avoidance practice because it involves a deliberate manipulation of prices charged between related parties based in different jurisdictions with a view to allocating an excessive part of the combined profits to the jurisdiction having the lowest effective tax rate. The Northern Indiana case seems to be a special case of price manipulation in which the interest spread was the price that Finance charged. Thus, when the court recognised the activity of Finance as a business activity, in effect it recognised tax avoidance as a business activity. Moreover, since it was undisputed that the transaction was structured in order to obtain a tax benefit, ${ }^{316}$ the court effectively justified one technique of tax avoidance, treaty abuse, with another, reinvoicing.

Further, although Finance invested its profits in unrelated investments to earn additional income, its position remained unchanged because it was wholly owned by Northern Indiana. It was created for a limited purpose and was liquidated after the purpose was accomplished. That is, within a predetermined time frame the profits reverted to Northern Indiana.

Even if it is assumed that profit indicates business activity, it cannot be regarded as an appropriate factor for deciding conduit company cases. As discussed section 4.6, business activity cannot be considered sufficient for

\footnotetext{
315 For example Cecil Bros Pty Ltd v Federal Commissioner of Taxation (1964) 111 CLR 430 (FC) and Liggett Group Inc $v$ Commissioner of Internal Revenue TC Memo 1990-18.

316 Northern Indiana Public Service Company $v$ Commissioner of Internal Revenue, above n 309, at 511.
} 
determining whether an interposed company can be categorised as a conduit company.

In Revenue Ruling $84-153,{ }^{317}$ which had similar facts and circumstances to Northern Indiana, the United States Internal Revenue Service based its ruling on the issue of whether a Netherlands Antilles subsidiary was acting as a conduit. Unlike the court in Northern Indiana, the IRS did not accord importance to the fact that the Antilles subsidiary earned a profit.

\subsection{Revenue Ruling 84-153: profit spread is not relevant at all}

Revenue Ruling 84-153 318 involved a United States parent corporation that maintained two wholly owned subsidiaries: one in the Netherlands Antilles and the other in the United States. The United States parent arranged for the Antilles subsidiary to raise funds by issuing Eurobonds. The Antilles subsidiary then on-lent the proceeds to the United States subsidiary at an interest rate that was one per cent higher than the rate payable to the Eurobond holders. In the process, the Antilles subsidiary earned a profit.

\footnotetext{
${ }^{317}$ Revenue Ruling 84-153 (1984) 2 св 383.

${ }^{318}$ Ibid, at 383.
} 


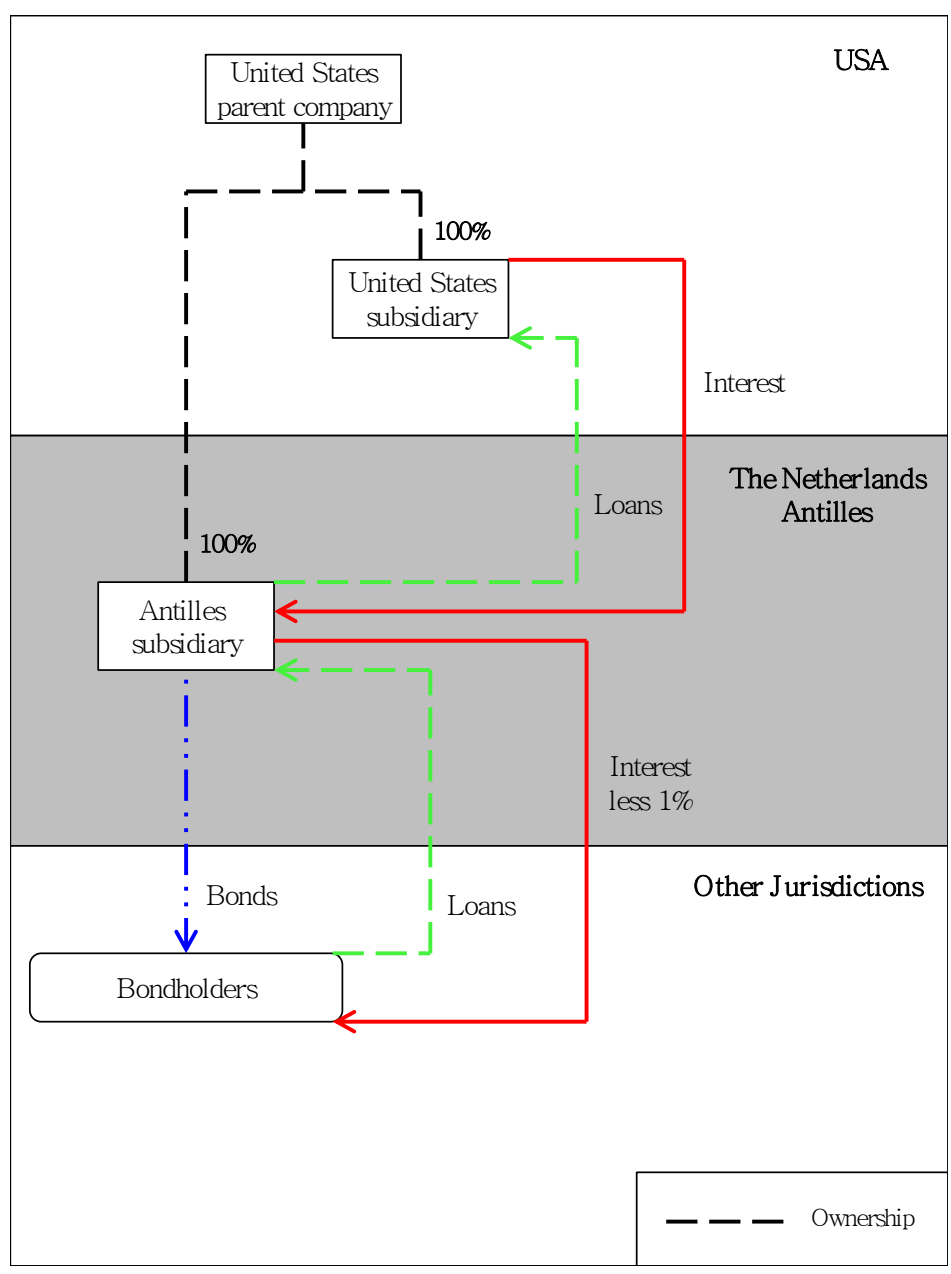

Figure 4.6: Revenue Ruling 84-153

The IRS ruled that the interest payments from the United States subsidiary to the Antilles subsidiary were not exempted from United States withholding tax under Article VIII(1) of the United States-Netherlands double tax treaty of 29 April $1948 .^{319}$ It pointed out that the use of the Antilles subsidiary in the transaction was tax-motivated and lacked "sufficient business or economic purpose to overcome the conduit nature of the transaction, even though it could be demonstrated that the transaction might

319 Convention with respect to Taxes on Income and certain other Taxes, the United States-the Netherlands (29 April 1948). The relevant part of Article VIII(1) read: "Interest (on bonds, securities, notes, debentures, or on any other form of indebtedness) ... derived from sources within the United States by a resident or corporation of the Netherlands not engaged in trade or business in the United States through a permanent establishment, shall be exempt from United States tax ...". 
serve some business or economic purpose". 320 That is, although the IRS seemed to acknowledge the existence of the profit spread, it did not consider the profit spread to be relevant.

The IRS based its ruling on the object and purpose of double tax treaties. When interpreting Article VIII(1) of the United States-Netherlands double tax treaty, it observed: ${ }^{321}$

The words "derived ... by" refer not merely to [the Antilles subsidiary's] temporarily obtaining physical possession of the interest paid by [the United States subsidiary], but to [the Antilles subsidiary] obtaining complete dominion and control over such interest payments ... [F]or purposes of the interest exemption in Article VIII(1) of the Convention, the interest payments by [the United States subsidiary] will be considered to be "derived ... by" the foreign bondholders and not by [the Antilles subsidiary].

The IRS's emphasis on the words "derived ... by" shows that it focused on the issue of whether the Antilles subsidiary was the substantive economic owner of the interest payments. It interpreted Article VIII(1) from a substantive economic point of view, which was consistent with the context in which double tax agreements function. That is why its approach seems more appropriate than that adopted by the courts in Northern Indiana.

As discussed in section 4.14, the courts decided Northern Indiana in the context of straw company and base company cases. They did not decide the case in accordance with the object and purpose of double tax treaties. Even if it is assumed that the courts in Northern Indiana did consider the object and purpose of double tax treaties, ${ }^{322}$ they misinterpreted Article VIII(1). ${ }^{323}$

\footnotetext{
${ }^{320}$ Revenue Ruling 84-153, above n 317, 383.

${ }^{321}$ Ibid.

322 Northern Indiana Public Service Company v Commissioner of Internal Revenue, above n 309, at 510.
} 
The Court of Appeals for the Seventh Circuit observed: "Under the terms of the Treaty, interest on a note that is "derived from" a United States corporation by a Netherlands corporation is exempt from United States taxation." 324 Although the interest payments in questions were made from 1982 to 1985, the United States Court of Appeals surprisingly chose to refer to Article VIII(1) as it stood before its amendment in $1965 .{ }^{325}$ Nevertheless, the relevant part of Article VIII(1), before its amendment in 1965, read:

Interest ... derived from sources within the United States by a resident or corporation of the Netherlands not engaged in trade or business in the United States through a permanent establishment, shall be exempt from United States tax ...

The court's interpretation of the provision shows that it emphasised the words "derived from", rather than the words "derived ... by" that the IRS emphasised in the Revenue Ruling 84-153. The court's observation suggests that rather than focusing on the issue of whether the substantive economic owner of the interest payments was resident in the Netherlands, the court was preoccupied with the fact that the taxpayer, Northern Indiana, was located in the United States. The observation reconfirms that the court analysed the facts erroneously.

\subsection{Reasons for the existence of Finance}

On an analysis of the facts of the Northern Indiana case in the light of the object and purpose of double tax treaties, it

\footnotetext{
${ }^{323}$ The United States-Netherlands double tax treaty of 29 April 1948, above $\mathrm{n} 319$.

324 Northern Indiana Public Service Company $v$ Commissioner of Internal Revenue 115 F 3d 506, 510 (7th Cir 1997).

325 The United States-the Netherlands double tax treaty of 29 April 1948, above n 319, art VIII(1).
} 
is hard to conclude logically that there were legitimate reasons for the existence of Finance in the whole structure.

The United States Court of Appeals for the Seventh Circuit observed: ${ }^{326}$

The Commissioner has suggested that [Northern Indiana's] tax-avoidance motive in creating Finance might provide one possible basis for disregarding the interest transactions between [Northern Indiana] and Finance. The parties agree that Taxpayer formed Finance to access the Eurobond market because, in the early 1980s, prevailing market conditions made the overall cost of borrowing abroad less than the cost of borrowing domestically. It is also undisputed that [Northern Indiana] structured its transactions with Finance in order to obtain a tax benefit - specifically, to avoid the thirty-percent withholding tax. What is in dispute is the legal significance of [Northern Indiana's] tax-avoidance motive.

As with the approach of the Swiss Federal Tax Administration in the $X$-group 1979 case, ${ }^{327}$ the court in the Northern Indiana case accepted that Northern Indiana structured the transaction in order to mitigate tax. Unlike the approach of the Swiss Federal Tax Administration, the court in Northern Indiana focused on the motive of the taxpayer.

The United States Court of Appeals emphasised that Northern Indiana wished to raise money for its business and the main purpose for interposing Finance was to escape the high domestic interest rate. The court, therefore, concluded that the arrangement was related to a business purpose. Although it considered the arrangement as a whole, it analysed the arrangement in the light of the motive of Northern Indiana, which it considered to be related to business and approved by law. ${ }^{328}$ The court

326 Northern Indiana Public Service Company $v$ Commissioner of Internal Revenue, above n 324, at 510.

${ }^{327}$ X-group 1979 (1979) 48 Archives de droit fiscal Suisse 271 at 275 (The Federal Tax Administration, Switzerland).

328 Northern Indiana Public Service Company $v$ Commissioner of Internal Revenue, above n 324, at 512. 
pointed out that the interposition of finance subsidiaries in the Netherlands Antilles was "not ... an uncommon practice" $^{, 32}$ and the legislative history of the Deficit Reduction Act $^{330}$ acknowledged this practice. The court, therefore, seemed to be of the view that domestic tax law approved of the practice.

Although domestic tax law may have approved the arrangement, it is hard to imagine that negotiators of double tax treaties would permit residents of a third state to obtain treaty benefits simply by establishing a company. Because the courts in Northern Indiana analysed the facts from the wrong frame of reference, they seemed to be so concerned with the fact that the taxpayer was a resident of the United States that they almost forgot that Eurobond holders, who were not residents of states other than contracting states, obtained the tax advantage.

Even if it is assumed that Finance had a business activity, its activity seemed uncomplementary to the business activity of Northern Indiana, which was a domestic utility company. Moreover, as mentioned in section 4.13, Finance was liquidated soon after Northern Indiana completed the payment of the principal amount plus the interest to the Eurobond holders. These facts suggest that, in the corporate structure, Finance did not have any significance other than as a conduit for passing on the interest to Eurobond holders.

\subsection{Can holding shares constitute a business activity?} As discussed in section 4.22, in G-group $2002,{ }^{331}$ the only business activity of Dutch BV was to hold shares of

\footnotetext{
329 Northern Indiana Public Service Company $v$ Commissioner of Internal Revenue, above n 324, at 513.

330 The Deficit Reduction Act (The United States) 1984.

${ }^{331}$ Re a Corporation (2002) 5 ITLR 589 at 602.
} 
GmbH. Dutch BV had no personnel or business premises. The business director of Dutch BV served as the business director of other affiliated companies in the Netherlands. According to the Bundesfinanzhof, Dutch BV's activity did not constitute "economic activity" under section $50 \mathrm{~d}(3)$ of the EStG. It observed: 332

\begin{abstract}
Additionally, there is no proof that the plaintiff has developed its own economic activity. To hold the participation in the German G-GmbH without any managing function does not fulfil the requirements that can be expected for such an activity. The fact that the Parent-Subsidiary directive of the European Union ... in art 2 uses the wording 'company of a Member State' without any requirements of an activity does not change the statement. Even if it were conclusive that, according to the Directive, to hold one single participation in a corporation and, therefore, the existence of a pure holding corporation were sufficient ..., a simple letterbox-company with only formal existence like the plaintiff, however, would not correspond to the supranational requirements.
\end{abstract}

The observation implies that regardless of the number of companies in which an intermediary holds shares, this activity does not fulfil the requirement of "economic activity" unless the intermediary carries out its own directorial functions. This approach was followed by the Bundesfinanzhof in G-group 2005.

As discussed in section 4.24, in G-group 2005, the affiliates out-sourced the passive shareholding activity to the Dutch subsidiaries in the long term. The Bundesfinanzhof considered holding of shares to be an economic activity. It emphasised two facts. First, the Dutch subsidiaries were carrying out the activity on their own account and were functioning autonomously. Second, in addition to shares in the German companies, the Dutch subsidiaries held shares in other foreign companies. ${ }^{333}$

\footnotetext{
${ }^{332}$ Re a Corporation, above n 331, at 601 (emphasis added).

${ }^{333}$ Ibid, at para 32.
} 
Holding shares should not be regarded as an economic activity even if the company manages its own operations. This argument applies even if the intermediary holds shares in more than one company. Holding shares is a weak form of economic activity, and the fact that an intermediary that holds shares also has an active board of directors does not necessarily add any substance to the shareholding activity, at least not in the context of double tax treaties. Such an intermediary can still act as a conduit.

A possible reason why the Bundesfinanzhof in G-group 2002 accorded importance to management functions could be that the court decided the case in the light of the reasoning of base company cases. As discussed in section 4.21 , since the court drew an analogy with base company cases, it was preoccupied with the issue of the recognition of an intermediary for tax purposes. As illustrated by Hospital Corporation of America, ${ }^{334}$ courts in base company cases tend to consider the presence of an active board of directors to indicate that a corporation carries out substantive business activity and therefore can be recognised for tax purposes. ${ }^{335}$ Nevertheless, G-group 2002 and G-group 2005 were conduit company cases and therefore should have been decided in the light of the object and purpose of the Germany-Netherlands double tax treaty. ${ }^{336}$

In G-group 2005 "managing function" acted as a misleading label that the Dutch subsidiaries gave to their

334 Hospital Corporation of America v Commissioner of Internal Revenue 81 TC 520 (1983).

335 Ibid, at 584.

${ }^{336}$ Convention for the Avoidance of Double Taxation with respect to Taxes on Income and Fortune and Various other Taxes, and for the Regulation of other Questions relating to Taxation, Germany-the Netherlands (16 June 1959, enter into force 18 September 1960). 
activity that appears no more than collecting and passing on of the dividends from the German companies to NV. That is, it hid the conduit nature of the Dutch subsidiaries and that helped them to obtain treaty benefits improperly. By recognising "management function" as "economic activity" under section $50 \mathrm{~d}(3)$, the Bundesfinanzhof effectively recognised the improper use of the tax treaty as economic activity.

\subsection{Reasons for the existence of the Dutch subsidiaries}

It is hard to find a reason for the existence of the Dutch subsidiaries in the G-group apart from obtaining the benefit of a full withholding tax reduction under the Germany-Netherlands double tax treaty.

Double tax treaties between the Netherlands and the resident states of most of the affiliates provided for a full reduction of withholding tax on dividends. The location of the Dutch subsidiaries ensured that dividends flowed from affiliates in general and German companies in particular ultimately to Bermuda with a minimum of tax.

Within the G-group, the Dutch subsidiaries acted as conduits. The Dutch subsidiaries had no employees, business premises or equipment. Their business director served several other affiliates. They had no activity apart from the holding of affiliates' shares.

As discussed in section 4.24, the Bundesfinanzhof accorded importance to the activity of the other affiliated companies. ${ }^{337}$ It noted that the Dutch subsidiaries formed part of a group of companies involved in the television sector. Within the group, they functioned as long-term shareholders of other affiliated companies. The court

337 G-group 2005 (31 May 2005) IR 74, 88/04 at para 32 (The Bundesfinanzhof, Germany). 
regarded these facts as "economic and other valid reasons" for the interposition of the Dutch subsidiaries. ${ }^{338}$

In contrast, when examining the activity of Dutch BV in G-group 2002, the Bundesfinanzhof observed: ${ }^{339}$

Finally, it is without any relevance in this connection that [Dutch BV's] sister-companies, also resident in the Netherlands, might fulfil the requirement of an economic activity and found an active functional part of the $G$ group. Assuming that this is true, the only economic activity of the sister-corporations may not be attributed to [Dutch BV] in a way that [Dutch BV] could be treated as a managing holding corporation.

Economic activity that is irrelevant to the income in question cannot be considered relevant when determining whether an intermediary acted as a conduit with respect to that income. In G-group 2005, the activity of the Dutch subsidiaries did not complement the activity of the affiliates that were involved in the television sector. That is, the existence of the Dutch subsidiaries did not serve the economic interest of the affiliates. Therefore, their activity does not add to the significance of Dutch subsidiaries in the G-group.

The German legislature amended section $50 \mathrm{~d}(3)$ of the EStG on 19 December 2006. In the language of the amended section 50d(3), the German legislature addressed specifically the loopholes exploited by the taxpayer in $G$ group 2005. The provision, however, still uses business activity as a criterion, and fails to cover situations in which an intermediary engages in an economic activity.

\subsection{The amended section $50 \mathrm{~d}(3)$ of the EStG}

Section $50 \mathrm{~d}(3)$, as it stands after its amendment on 19 December 2006, reads: ${ }^{340}$

338 G-group 2005, above n 337, at para 31 (bb).

${ }^{339}$ Re a Corporation (2002) 5 ITLR 589 at 601.

${ }^{340}$ Einkommensteuergesetz [EStG] [Income Tax Act], 16 October 1934 BGBl I at 3366 as amended by Jahressteuergesetzes [Finance Law], 13 
${ }^{1} \mathrm{~A}$ foreign company is not entitled to a full or partial relief under sections 1 and 2, if and to the extent persons with a holding in it, are not entitled to reimbursement or exemption, had they received income directly, and

1. There is no economic or other relevant reason to establish the foreign company or

2. The foreign company does not earn more than 10 per cent of its gross income from its own economic activity or

3. The foreign company does not participate in general commerce with business premises suitably equipped for a business purpose.

${ }^{2}$ Only the situations of the foreign company are decisive; organisational, economic and other significant features of companies, that have close relations to the foreign company ... shall not be considered. ${ }^{3}$ Own business operations shall be regarded as absent, as long as the foreign company earns its gross returns from the management of assets or a third party is in charge of their essential business operations. ${ }^{4}$ Sentences 1 to 3 shall not be applied, if the main class of the shares of the foreign company are traded substantially and regularly on a recognised stock exchange or the foreign company is subjected to the rules and regulations of the Investment Tax Act.

By quantifying "economic activity", and by clarifying its meaning, the provision may prevent companies without a business activity from obtaining the benefit of withholding tax reductions under a double tax treaty; it fails, however, to cover situations in which an interposed foreign company acts as a conduit despite being involved in a genuine business activity. Such a situation existed in Ministre de l'Economie, des Finances et de l'Industrie $v$ Société Bank of Scotland. ${ }^{341}$

Although Bank of Scotland ${ }^{342}$ was a French case and it did not concern section $50 \mathrm{~d}(3)$ of the EStG at all, it is relevant in the present context because it illustrates that section $50 \mathrm{~d}(3)$ would have failed to function effectively

December $2006 \mathrm{BGBl}$ I at $2878, \S 50 \mathrm{~d}, \boldsymbol{9} 3$. The numbering system adopted with superscript numbers 1 to 4 is the the numbering system of the Einkommensteuergesetz. These superscript numbers appear at the beginning of the sentences, and are not paragraph numbers.

${ }^{341}$ Ministre de l'Economie, des Finances et de l'Industrie v Société Bank of Scotland (2006) 9 ITLR 683 (Conseil d'etat, France).

${ }^{342}$ Ibid. 
given the facts and circumstances of Bank of Scotland. The Bank of Scotland case concerned an attempt by a United States company, Pharmaceutical Inc, to use the United Kingdom as the intermediary jurisdiction in a conduit transaction for income flowing from France to the United States, trying in the process to take advantage of the provisions of the double tax treaty between France and the United Kingdom. Although Bank of Scotland is a French case that involved an unrelated conduit company, it helps to explain the foregoing argument because the conduit company was engaged in substantive business activity.

\subsection{The Bank of Scotland case}

Pharmaceuticals Inc held all the shares in Marion SA, a French company. In 1992, Pharmaceuticals Inc sold the usufruct of some shares issued by Marion SA to the Bank of Scotland for three years. The Bank of Scotland acquired the usufruct in consideration of a single payment. Under the usufruct contract, the Bank of Scotland was entitled to receive a pre-determined amount of dividend from Marion SA in three-year period. Pharmaceuticals Inc guaranteed the payment of dividends.

Article $9(6)^{343}$ of the France-United Kingdom double tax treaty of 22 May 1968 reduced the French withholding

\footnotetext{
343 Convention for the Avoidance of Double Taxation and the Prevention of Fiscal Evasion with respect to Taxes on Income, France-the United Kingdom (22 May 1968, entered into force 27 October 1969), art 9(6). It provided: "Dividends paid by a company which is a resident of France to a resident of the United Kingdom may be taxed in the United Kingdom. Such dividends may also be taxed in France but where such dividends are beneficially owned by a resident of the United Kingdom the tax so charged shall not exceed:
}

(a) 5 per cent of the gross amount of the dividends if the beneficial owner is a company which controls the company paying those dividends;

(b) in all other cases 15 per cent of the gross amount of the dividends." 
tax to 15 per cent on dividends distributed to a company resident in United Kingdom. Further, Article $9(7)^{344}$ of the treaty provided for a refund of the avoir fiscal after the deduction of the withholding tax. Pharmaceuticals Inc designed the arrangement in order to obtain benefits of these provisions. If Pharmaceuticals Inc had received dividends directly from Marion SA, it would have paid 15 per cent French withholding tax under the France-United States double tax treaty of 31 August $1994 .{ }^{345}$ The arrangement would have allowed Pharmaceutical Inc to receive dividends free of French withholding tax. Further, at the end of three years period, the Bank of Scotland would have received the total amount of dividends plus the refund of avoir fiscal, which was greater than the amount it initially paid to Pharmaceuticals Inc.

In 1993, Marion SA distributed dividends to the bank after deducting 25 per cent French withholding tax. The bank applied to the French tax administration for a partial refund of the withholding tax and a reimbursement of the avoir fiscal tax credit under the France-United Kingdom double tax treaty.

344 The France-United Kingdom double tax treaty, above n 343, art 9(7). The relevant part of the Article 9(7) provided "A resident of the United Kingdom who receives from a company which is a resident of France dividends which, if received by a resident of France, would entitle such resident to a fiscal credit (avoir fiscal), shall be entitled to a payment from the French Treasury equal to such credit (avoir fiscal) subject to the deduction of the tax provided for in sub-paragraph (b) of paragraph (6) of this Article."

345 Convention for the Avoidance of Double Taxation and the Prevention of Fiscal Evasion with respect to Taxes on Income and Capital, France-the United States (31 August 1994, entered into force 8 December 2004), art 10(2)(b). 


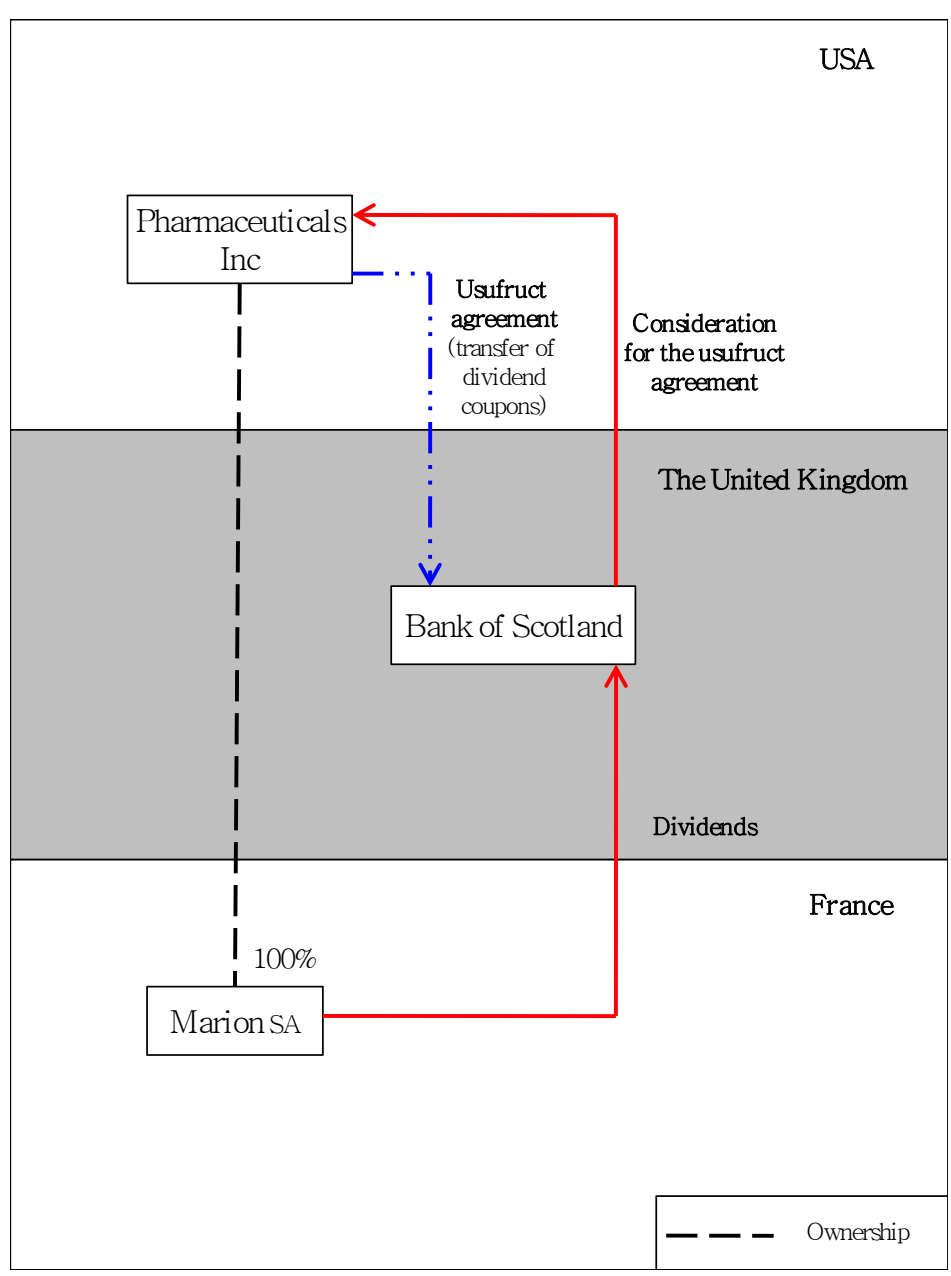

Figure 4.7: The Bank of Scotland case

The French tax administration denied the request on the grounds that the Bank of Scotland was not the beneficial owner of the dividends. The French tax administration characterised the transactions as a loan made by the bank to Pharmaceuticals Inc, which was repaid by the dividends from Marion SA.

The Supreme Administrative Court ruled in favour of the French tax administration. According to the court, only the beneficial owner of the dividends was entitled to a refund of withholding tax and the reimbursement of the tax credit under the France-United Kingdom double tax treaty. ${ }^{346}$ After analysing the contractual arrangement, it

\footnotetext{
${ }^{346}$ The France-United Kingdom double tax treaty of 22 May 1968,
} above $\mathrm{n} 97$. 
was of the opinion that Pharmaceutical Inc was the beneficial owner and had delegated the repayment of the loan to Marion SA. ${ }^{347}$ The court found that the sole purpose of the arrangement was to obtain the benefit of avoir fiscal tax credit available under the France-United Kingdom double tax treaty, ${ }^{348}$ which was not available under the double tax treaty between France and the United States. $^{349}$ The Supreme Administrative Court refused treaty benefits to the Bank of Scotland because it did not consider the bank to be the beneficial owner.

\subsection{Would section $50 \mathrm{~d}(3)$ have worked in the facts and circumstances of Bank of Scotland?}

If it is assumed that a taxpayer had used the tax-planning scheme in the Bank of Scotland case for obtaining tax relief under a German tax treaty, it is possible that the Bank of Scotland, as a foreign company, would have been allowed a withholding tax reduction by virtue of the business activity test under section 50d(3) EStG. The bank seemed to satisfy the conditions in the provision. It was involved in a business activity and earned more than 10 per cent of its gross income from it. It had business premises and it participated in general commerce. Although there were no economic or other relevant reasons for interposing the Bank of Scotland, it would still have been entitled to treaty benefits because its shares were traded substantially and regularly on a recognised stock exchange.

\footnotetext{
${ }^{347}$ Ministre de l'Economie, des Finances et de l'Industrie v Société Bank of Scotland, above n 341, at 703.

${ }^{348}$ The France-United Kingdom double tax treaty of 22 May 1968, above $\mathrm{n} 97$.

${ }^{349}$ The France-United States double tax treaty of 31 August 1994, above $\mathrm{n} 345$.
} 
This result does not make sense in the context of double tax treaties. The bank could not be considered to be the owner of the income in a substantive economic sense, regardless of the fact that it was involved in genuine business activity. That is, although the conditions in the amended version of section $50 \mathrm{~d}(3)$ are independent, business activity works as a conclusive criterion at least in some situations. That is, the new version of section $50 \mathrm{~d}(3)$ does not necessarily overcome the shortcomings of its older version.

This analysis confirms that the absence of business activity may establish that an intermediary is a mere conduit; however, the fact that an intermediary is involved in business activity does not necessarily show that it is not acting as a conduit.

\subsection{Conclusion}

Although different reports of the OECD and courts substitute the substantive business activity test for the beneficial ownership test, it is not related to the concept of ownership at all.

Originally, courts have applied the substantive business activity test to cases involving straw companies and base companies. The focal issue in these cases is whether a corporation should be recognised for tax purposes. Courts have considered the presence of substantive business activity to be sufficient in order to recognise a corporation as a separate taxable entity. Conduit company cases prima facie appear similar to straw company cases and base company cases. Probably for this reason, courts apply the substantive business activity to conduit company cases with the reasoning they have adopted in cases involving straw companies and base companies. 
Unlike cases involving straw companies and base companies, however, conduit company cases should be determined in the context of the object and purpose of double tax treaties. Although the absence of a business activity indicates that the interposition of an intermediary lacks substance even for the purpose of qualifying for treaty benefits, its presence does not necessarily indicate that the interposition of an intermediary does not contradict the object and purpose of a double tax treaty. It follows that the business activity criterion can work only as a one-way test in conduit company cases. In other words, the substantive business activity test cannot logically be applied as a decisive test to conduit company cases. 


\section{CHAPTER 5 \\ DOMINION}

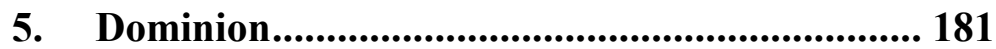

5.1. Introduction ..................................................... 181

5.2. Paragraph 14(b) of the Conduit Companies Report

5.3. Conceptual and linguistic confusions.................. 184

5.4. "Narrow powers": the absence of dominion........ 185

5.5. The obligation to pass on passive income in property law

5.6. Bank of Scotland: the absence of an obligation in property law is indecisive 188

5.7. Obligation to pass on passive income in contract law 191

5.8. Aiken Industries: complete dominion and control 191

5.9. The Indofood case 194

5.10. Indofood: the presence of a contractual obligation and beneficial ownership. 198

5.11. The example of a "nominee or agent" as conduit: a fallacy 201

5.12. Royal Dutch Shell ............................................. 203

5.13. Reasons for the existence of X Ltd .................... 206

5.14. The Prévost Car case ....................................... 208

5.15. Prévost Car: dominion an indicator of beneficial ownership 210

5.16. Prévost Car: analogy between nominees and agents, and conduit companies

5.17. Prévost Car: analogy between the beneficial ownership test and piercing the corporate veil .... 213

5.18. Reasons for the existence of Dutch BV............... 215

5.19. Conclusion ........................................................ 217

\subsection{Introduction}

As discussed in section 2.30, dominion is a surrogate form of reasoning courts have used to apply the beneficial ownership test to conduit company cases. The word "dominion" is not a term of art. This chapter uses it in order to represent an incident that exhibits ownership. Salmond describes rights and liberties that belong to this incident as follows: ${ }^{350}$

350 John William Salmond and P J Fitzgerald Salmond on Jurisprudence (12th ed, Sweet and Maxwell, London, 1966) at 246. 
[T] he owner normally has the right to use and enjoy the thing owned: the right to manage it, i.e., the right to decide how it shall be used; and the right to the income from it. ..., these rights are in fact liberties: the owner has a liberty to use it, in contrast with others who are under a duty not to use or interfere with it.

That is, in essence "dominion" is a property right. ${ }^{351}$

The OECD's Conduit Companies Report uses the criterion of the absence of dominion for determining whether a recipient company is not the beneficial owner of passive income. It borrows the dominion test from cases in which a tax authority argues that a recipient company acts in the capacity of a "nominee or agent". The role of a nominee or agent is to pass on income to its principal. One result is that nominee or agent does not have dominion. That is why the OECD Model Convention does not regard a nominee or agent as the beneficial owner.

It does not make sense to decide conduit company cases on the basis of the criterion of dominion because companies are, by definition, owners of their income. A nominee or agent is under an obligation to pass on its income in property law, whereas a conduit company may pass on passive income because of a contractual obligation. It is also possible that a conduit company has no contractual obligation to pass on passive income. In a practical sense, however, a conduit company distributes the passive income to its shareholders as dividends, or deals with the passive income in a manner that eventually benefits its shareholders.

The chapter argues that the use of a "nominee or agent" by the official commentary as an example of conduits is misleading. The use of a nominee or agent as an example of conduits implies that the presence of dominion justifies

351 See Lawrence C Becker Property Rights: Philosophical Foundations (Routledge and Kegan Paul, London, 1977) at 18. 
considering a recipient of passive income to be its beneficial owner. The criterion of dominion is, however, not necessarily decisive for solving conduit company cases. The focal issue in conduit company cases should be whether the arrangement is consistent with the object and purpose of a double tax agreement.

\subsection{Paragraph 14(b) of the Conduit Companies Report}

Paragraph 14(b) of the OECD's Conduit Companies Report of $1987^{352}$ discusses the application of the beneficial ownership test to conduit companies under Article 10(2), 11(2) and 12(1) of the OECD Model Convention. It uses the criterion of "dominion". It states: $:^{353}$

Articles 10 to 12 of the OECD Model deny the limitation of tax in the State of source on dividends, interest and royalties if the conduit company is not its "beneficial owner". Thus the limitation is not available when, economically it would benefit a person not entitled to it who interposed the conduit company as an intermediary between himself and the payer of the income ... . The Commentaries mention the case of a nominee or agent. The provisions would, however, apply also to other cases where a person enters into contracts or takes over obligations under which he has a similar function to those of a nominee or an agent. Thus a conduit company can normally not be regarded as the beneficial owner if, though the formal owner of certain assets, it has very narrow powers which render it a mere fiduciary or an administrator acting on account of the interested parties (most likely the shareholders of the conduit company). In practice, however, it will usually be difficult for the country of source to show that the conduit company is not the beneficial owner. The fact that its main function is to hold assets or rights is not itself sufficient to categorise it as mere intermediary, although this may indicate that further examination is necessary.

The significance of paragraph 14(b) is evident from the fact that the official commentary on Articles 10, 11 and 12

\footnotetext{
352 OECD Committee on Fiscal Affairs "Double Taxation Conventions and the Use of Conduit Companies" in OECD Committee on Fiscal Affairs International Tax Avoidance and Evasion: Four Related Studies, Issues in International Taxation No 1 (OECD, Paris, 1987) 87 at para $14(b)$.

${ }^{353}$ Ibid.
} 
of the OECD Model Convention has incorporated the paragraph since the amendment of the Model Convention in 2003. ${ }^{354}$ Further, when applying the dominion test to conduit companies as a surrogate test for the beneficial ownership test, some courts relied on this paragraph. ${ }^{355}$ For this reason, it becomes important to begin with an analysis of the paragraph.

\subsection{Conceptual and linguistic confusions}

As discussed in section 2.26, this paragraph is based on an illogical assumption. It assumes that in some situations a conduit company can be regarded as the beneficial owner. From a substantive economic point of view, it is hard to consider a company that acts as a conduit to be the beneficial owner. Further, in the first sentence, the phrase "if the conduit company is not its 'beneficial owner",356 creates a linguistic confusion. It implies that a "conduit company" is different from a company that is not the beneficial owner.

The paragraph seems to use the term "conduit company" for a company that immediately receives passive income from the source company but does not work in the capacity of a nominee or agent. Because it is not necessary that such a company always works as a

354 OECD Committee on Fiscal Affairs "Commentary on Article 10 concerning the Taxation of Dividends" (OECD, Paris, 2010) in OECD Committee on Fiscal Affairs Model Tax Convention on Income and on Capital (OECD, Paris, 2010) 187 at para 12.2. OECD Committee on Fiscal Affairs "Commentary on Article 11 concerning the Taxation of Interest" (OECD, Paris, 2010) in OECD Committee on Fiscal Affairs Model Tax Convention on Income and on Capital (OECD, Paris, 2010) 211 at para 10. OECD Committee on Fiscal Affairs "Commentary on Article 12 concerning the Taxation of Royalties" (OECD, Paris, 2010) in OECD Committee on Fiscal Affairs Model Tax Convention on Income and on Capital (OECD, Paris, 2010) 220 at para 4.1.

${ }^{355}$ For example Prévost Car Inc v Her Majesty the Queen (2008) TCC 231 and Royal Dutch Shell (6 April 1994) Case no 28 638, BNB 1994/217 (the Hoge Raad, the Netherlands).

${ }^{356}$ The Conduit Companies Report, above n 352, at para 14(b). 
conduit, this chapter uses the term "recipient company" in order to avoid confusion.

\section{4. "Narrow powers": the absence of dominion}

Paragraph 14(b) refers to the official commentary on Articles 10, 11 and 12 of the OECD Model Convention of 1977. The official commentary on Articles 10 and 11 stated: ${ }^{357}$

Under paragraph 2, the limitation of tax in the State of source is not available when an intermediary, such as an agent or nominee, is interposed between the beneficiary and the payer, unless the beneficial owner is a resident of the other Contracting State.

The official commentary on Article 12 was similar: ${ }^{358}$

Under paragraph 1, the exemption from tax in the State of source is not available when an intermediary, such as an agent or nominee, is interposed between the beneficiary and the payer, unless the beneficial owner is a resident of the other Contracting State.

Paragraph 14(b) suggests that the official commentary used a "nominee or agent" as an example of conduits.

An agent hands over money belonging to his principal, which is received for the principal's use. ${ }^{359}$ Similarly, a nominee passes on money to its mandator. For this reason, a nominee or agent does not qualify as the beneficial owner of passive income.

Agents and nominees pass on money to the person on whose behalf they work because property rights are vested

357 OECD Committee on Fiscal Affairs "Commentary on Article 10 concerning the Taxation of Dividends" (OECD, Paris, 1977) in OECD Committee on Fiscal Affairs Model Tax Convention on Income and on Capital (OECD, Paris, 1977) 150 at para 12. OECD Committee on Fiscal Affairs "Commentary on Article 11 concerning the Taxation of Interest" (OECD, Paris, 1977) in OECD Committee on Fiscal Affairs Model Tax Convention on Income and on Capital (OECD, Paris, 1977) 169 at para 8 .

358 OECD Committee on Fiscal Affairs "Commentary on Article 12 concerning the Taxation of Royalties" (OECD, Paris, 1977) in OECD Committee on Fiscal Affairs Model Tax Convention on Income and on Capital (OECD, Paris, 1977) 182 at para 4.

${ }^{359}$ See G H L Fridman Law of Agency (2nd ed, Butterworths, London, 1966) at 10 . 
in that person. They, therefore, do not have the freedom to decide how to use the money. That is, they lack dominion. Thus, in order to determine whether a relationship between two persons is an agency relationship, courts occasionally address the issue of whether the alleged agent has dominion over its business and income that it derives from the business. In such cases, the criterion of dominion has been referred to as "control". 360

As with agents and nominees, conduit companies appear to pass on income to residents of a third state. This could be why paragraph 14(b) draws an analogy between the function of a conduit company and the role of a nominee or agent. The paragraph regards a conduit company as a person who "enters into contracts or takes over obligations under which he has a similar function to those of a nominee or agent". ${ }^{361}$ By applying the analogy, the report transposes the dominion test to conduit companies. It could be inferred, therefore, that the phrase "narrow powers" in paragraph 14(b) means the absence of the freedom to decide how to use passive income. That is, the term could be equated with the absence of dominion.

It is illogical, however, to transpose the dominion test from cases involving nominees or agents to conduit company cases simply because they both pass on passive income. Reasons why conduit companies may pass on passive income differ from the reason for which nominees or agents pass on income. While nominees and agents are obliged under property law to pass on income to the

\footnotetext{
${ }^{360}$ For example South Sydney District Rugby League Football Club Ltd $v$ News Ltd and Others (2000) 177 ALR 611 and Royal Securities Corp Ltd v Montreal Trust Co (1966) 59 DLR (2d) 666 at 684. See also William Bowstead and F M B Reynolds Bowstead and Reynolds on Agency (18th ed, Sweet \& Maxwell, London, 2006) at para 1-017.

${ }^{361}$ The Conduit Companies Report, above n 352, at para 14(b).
} 
person on whose behalf they work, conduit companies are under no obligation in property law to pass on passive income. A conduit company may be under a contractual obligation to do so; however, in such a case contact law, not property law, creates the obligation. The following sections discuss obligations to pass on passive income under property law and contract law separately.

\subsection{The obligation to pass on passive income in property law}

As indicated earlier, in cases involving nominees or agents, the property is owned by the person for whom they work. For this reason, in property law, a nominee or agent is obliged to pass on income. ${ }^{362}$ In such cases, income originates as the property of a person on whose behalf the nominee or agent receives it. That is, the income is destined to reach that person in the form it arises.

In conduit company cases, by contrast, passive income originates as the property of a recipient company. That is, if the recipient company passes the income on to a company that is resident in a third state, it does so in the capacity of the owner of the income. For this reason, even if a recipient company is interposed as a conduit company that does not act as a nominee or agent, it is under no obligation in property law to pass on passive income to the resident of a third state. Conduit structures are often achieved by interposing a subsidiary as an immediate recipient. Although in such cases the subsidiary passes on passive income in the form of dividends to its shareholders

362 See John William Salmond and P J Fitzgerald Salmond on Jurisprudence (12th ed, Sweet and Maxwell, London, 1966) at 258. G H L Fridman Law of Agency (2nd ed, Butterworths, London, 1966) at 10. F E Dowrick "The Relationship of Principal and Agent" (1954) 17 MLR 24, at 32. 
who are resident in a third state, it is not obliged to do so under property law.

The whole idea of company law is that companies are independent and are able to control their property. It follows that conduit companies are, by definition, the owners of passive income they receive. In other words, conduit companies have dominion over passive income simply by virtue of being corporations.

It therefore does not make sense to apply the dominion test to decide whether a recipient company is the beneficial owner. If the criterion of dominion is used for deciding conduit company cases, a recipient company will always qualify for treaty benefits regardless of whether any tax planning arrangement in issue is inconsistent with the object and purpose of a double tax agreement. The opinion of the Government Commissioner, Mr. François Séners, in Ministre de l'Economie, des Finances et de l'Industrie v Société Bank of Scotland ${ }^{363}$ supports this argument.

\subsection{Bank of Scotland: the absence of an obligation in property law is indecisive}

Recalling the facts of the Bank of Scotland case from section 4.32, the French tax administration did not consider the bank to be the beneficial owner, and therefore, rejected the bank's request of a partial refund of the withholding tax and a reimbursement of the avoir fiscal tax credit under the France-United Kingdom double tax treaty of 22 May $1968 .^{364}$ The case went to the Supreme Administrative Court.

${ }^{363}$ Ministre de l'Economie, des Finances et de l'Industrie v Société Bank of Scotland (2006) 9 ITLR 683, at 711.

364 Convention for the Avoidance of Double Taxation and the Prevention of Fiscal Evasion with respect to Taxes on Income, 
When advising the court, the Government Commissioner agreed with the tax administration. He analysed several explanations of the term "beneficial owner", which excluded from the description of a beneficial owner nominees or agents, or a person who received income for the account of another person. He concluded: ${ }^{365}$

The doctrinal analyses are united [in] the fact that the direct recipient of income is not entitled to obtain the advantages granted by international tax treaties if he is not the ultimate recipient of this income and if he has only received it in the status of intermediary for another person to whom the income is destined to be transferred in one form or another.

This analysis does not completely resolve the question in the present case which is more complex since, as the Bank of Scotland contends, it has truly received, for its own account and as the ultimate recipient, the dividends distributed by [Marion SA]. This could lead you to conclude that despite the triangular arrangement operated with the companies in the ... group, it was the beneficial owner of the dividends paid. The fact that it could be regarded in this matter as a lender with respect to [Pharmaceuticals Inc] did not however prevent the latter from freeing itself from this debt by the grant of a real right that it held with regard to [Marion SA].

I think nevertheless that this case reveals that the notion of beneficial ownership cannot be reduced to cases of transfer of intended benefits and that, by its nature, it encompasses situations of fraud on the law ...

If you are with me on this conceptual territory, it remains only to judge whether, in this particular case, there was an abusive arrangement ...

The Government Commissioner used the phrase "beneficial ownership ... by its nature ... encompasses situations of fraud on the law". The usage shows that he regarded the beneficial ownership test as an antiavoidance test, not a test of ownership. He applied the beneficial ownership test in the manner of the general antiavoidance doctrine of abuse of law, which is essentially

France-the United Kingdom (22 May 1968, entered into force 27 October 1969), arts 9(6) and 9(7).

${ }^{365}$ Ministre de l'Economie, des Finances et de l'Industrie v Société Bank of Scotland, above n 363, at 711 (emphasis added). 
the approach of the predication test in another guise. Similar to the approach adopted by Lord Denning in the Newton's case, ${ }^{366}$ the Government Commissioner generalised the application of the beneficial ownership test. That is, he did not concretise the law by basing his decision on the absence or presence of a specific criterion, in this case the criterion of dominion. The observation shows that he regarded the presence of dominion as insufficient to determine whether the Bank of Scotland was the beneficial owner. Essentially, in his opinion although the bank had dominion over the dividends, it was involved in an arrangement that was inconsistent with the object and purpose of the France-United Kingdom double tax treaty. He advised the court to apply the abuse of law doctrine.

The approach of the Supreme Administrative Court seemed to align with the advice of the Government Commissioner. The court accorded no significance to the presence of dominion. It examined the arrangement and found that the usufruct contract concealed a loan agreement between the bank and Pharmaceuticals Inc. On an analysis of the usufruct agreement, the court concluded that the beneficial owner of the dividend payments was Pharmaceuticals Inc, which delegated the repayment of the loan to Marion SA. The usufruct agreement was motivated solely by tax reasons, with the aim of benefiting from the reimbursement of the avoir fiscal tax credit available under the France-United Kingdom double tax

\footnotetext{
${ }^{366}$ L J Newton v Federal Commissioner of Taxation (1958) 98 CLR 1,
} at 8 (Privy Council, Australia). 
agreement. ${ }^{367}$ In essence, the court based its decision on the substance of the usufruct agreement.

The Bank of Scotland case illustrates that, even if a recipient company has dominion over passive income, it can still act as a conduit. The focal issue in conduit company cases, therefore, should be whether the arrangement is consistent with the object and purpose of a double tax agreement.

\subsection{Obligation to pass on passive income in contract law}

A recipient company may be bound to pass on passive income by a contract, and therefore, has narrow powers. However, the existence of narrow powers in such a case is a result of a contractual obligation, not a result of an obligation in property law. The recipient company still has dominion over passive income and it can opt not to pass on the income. It will breach the contract, if it opts not to pass on the income; however, contract law will govern the situation.

A contractual obligation to pass on passive income, however, seems indecisive for solving conduit company cases because its presence or absence does not answer the question of whether the arrangement contradicts the object and purpose of a double tax treaty. This point can be illustrated with the help of Aiken Industries Inc $v$ Commissioner of Internal Revenue. ${ }^{368}$

\subsection{Aiken Industries: complete dominion and control} As discussed in section 2.4, the Aiken Industries case involved Ecuadorian Ltd, a Bahamian company that made

\footnotetext{
${ }^{367}$ Ministre de l'Economie, des Finances et de l'Industrie v Société Bank of Scotland, above n 363, at 703.

${ }^{368}$ Aiken Industries Inc v Commissioner of Internal Revenue $56 \mathrm{TC}$ 925 (1971) 934
} 
a loan to Mechanical Inc, a United States company, in exchange for a note. If Ecuadorian Ltd had received interest directly from Mechanical Inc, it would have incurred United States withholding tax. Ecuadorian Ltd interposed Industrias, a Honduran company. In effect, Industrias borrowed from Ecuadorian Ltd and lent to Mechanical Inc by a back-to-back loan. Thus, the interest flowed from the United States to the Bahamas through Honduras. The object was to obtain the United States withholding tax exemption under Article IX of the United States-Honduras double tax treaty. ${ }^{369}$

The United States Tax Court held that "Industrias had no actual beneficial interest in the interest payments it received". ${ }^{370}$ When interpreting Article IX of the United States-Honduras double tax treaty, the court observed: ${ }^{371}$

As [utilised] in the context of article IX, we interpret the terms "received by" to mean interest received by a corporation of either of the contracting States as its own and not with the obligation to transmit it to another. The words "received by" refer not merely to the obtaining of physical possession on a temporary basis of funds representing interest payments from a corporation of a contracting State, but contemplate complete dominion and control over the funds.

The court used the phrase "complete dominion and control" to represent an attribute of beneficial ownership; however, as discussed in section 2.5, it interpreted the beneficial ownership concept for treaty purposes, which led it to use the phrase in a substantive economic sense.

The court seemed to appreciate that because of the obligation under the loan contract with Ecuadorian Ltd,

${ }^{369}$ Convention for Avoidance of Double Taxation and the Prevention of Fiscal Evasion with Respect to Taxes on Income, the United States-Honduras (25 June 1956, entered into force 6 February 1957). The convention was terminated on 31 December 1966.

${ }^{370}$ Aiken Industries Inc v Commissioner of Internal Revenue, above $\mathrm{n}$ 368 , at 934 .

${ }^{371}$ Ibid, at 933 (emphasis added). 
Industrias lacked "complete dominion and control" over the interest payments, or had narrow powers over the interest payments. The court focused, however, on the issue of whether Industrias's contractual obligation had substance. It observed: $:^{372}$

\begin{abstract}
The convention requires more than a mere exchange of paper between related corporations to come within the protection of the exemption from taxation granted by article IX of the convention, and on the record as a whole, [Aiken Industries] has failed to demonstrate that a substantive indebtedness existed between a United States corporation and a Honduran corporation.
\end{abstract}

Further, the court noted that transactions occurred between related parties and that Industrias was left with the same inflow and outflow of funds. Based on these facts it observed "... we cannot find that this transaction had any valid economic or business purpose". 373 The court's analysis of the facts shows that it intended to refer to the arrangement as a whole, when it used the words "this transaction". It held that Industrias could not be regarded as having "received" the interest within the meaning of Article IX of the United States-Honduras double tax treaty. ${ }^{374}$ Essentially, the court investigated whether the effect of the arrangement was improper use of the treaty.

The approach adopted by the United States Tax Court implies that the presence of a contractual obligation to pass on passive income in itself is insufficient for regarding an interposed company a conduit. The England and Wales Court of Appeal adopted this approach

\footnotetext{
${ }^{372}$ Aiken Industries Inc v Commissioner of Internal Revenue, above $\mathrm{n}$ 368, at 933 (emphasis added).

${ }^{373}$ Ibid, at 934.

${ }^{374}$ Ibid.
} 
explicitly in Indofood International Finance Ltd $v J P$ Morgan Chase Bank NA, London Branch. ${ }^{375}$

\subsection{The Indofood case}

In 2002, Indofood, an Indonesian corporation wanted to raise funds by issuing loan notes on the international market. If Indofood issued notes, it would have to withhold 20 per cent tax on interest payments to note holders whose country of residence did not have a double tax agreement with Indonesia. That is, issuing notes directly in the international market would have increased the tax cost on interest payments for Indofood.

The Indonesia-Mauritius double tax treaty of 10 December $1996^{376}$ was in effect in 2002. Article 10(2) of the treaty limited Indonesian withholding tax on interest payments by 10 per cent. In order to reduce the tax cost, Indofood incorporated a Mauritian subsidiary, which will be referred to as Finance. Finance borrowed money from the international bond market on loan notes and on-lent the proceeds to Indofood.

\footnotetext{
${ }^{375}$ Indofood International Finance Ltd v JP Morgan Chase Bank NA, London Branch [2006] EWCA Civ 158.

${ }^{376}$ Convention for Avoidance of Double Taxation and the Prevention of Fiscal Evasion with Respect to Taxes on Income, IndonesiaMauritius (10 December 1996, entered into force 12 January 1998), art 10(2).
} 


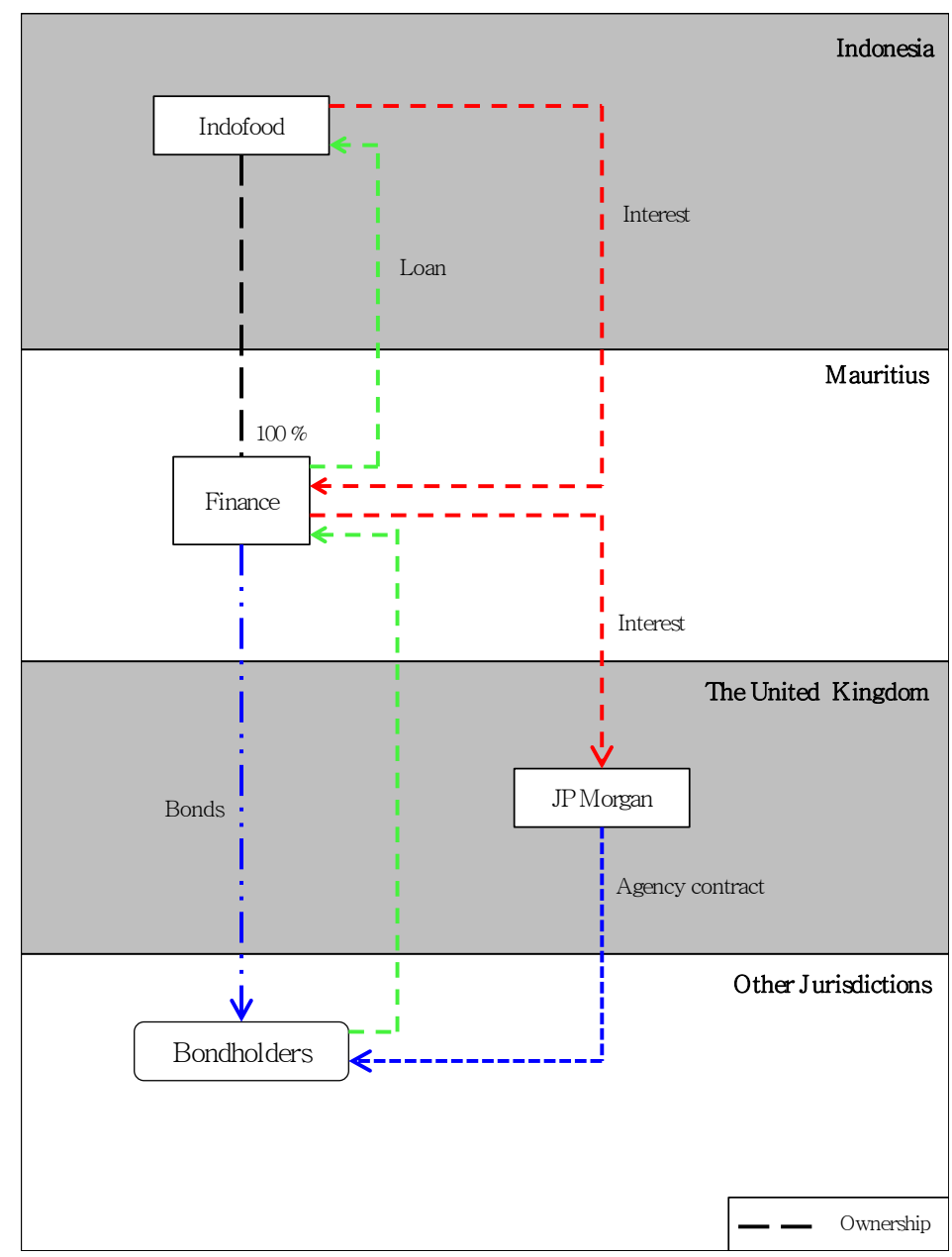

Figure 5.1: The Indofood case - before the termination of the treaty

The loan notes were issued for five years and were governed by the law of the United Kingdom. Their conditions required Indofood to pay interest to Finance. Finance in turn was obliged to transfer the interest to JP Morgan, a bank in the United Kingdom, which acted as the trustee and principal paying agent for the note holders. The conditions allowed Finance to redeem the loan notes at par, if a change in the law of Indonesia caused Indofood to deduct more than 10 per cent withholding tax. They required Finance to take "reasonable measures" 377 before redeeming the notes.

${ }^{377}$ Indofood International Finance Ltd v JP Morgan Chase Bank NA, London Branch, above n 375, at para 2. 
After the first interest payment to Finance, Indofood paid interest directly to the bank. In 2004, Indonesia gave notice to terminate the Indonesia-Mauritius double tax treaty. Since Indofood would have had to withhold tax at 20 per cent after the termination of the treaty, it decided to redeem the notes.

JP Morgan contended that the conditions of loan notes required Indofood to take "reasonable measures". It proposed that, as a reasonable measure, Indofood should incorporate a Dutch subsidiary, which will be referred to as Dutch BV, and should assign Dutch BV the ownership of its debt to Finance. It presumed that Dutch BV would be entitled to an Indonesian withholding tax reduction under Article 10(2) of the Indonesia-Netherlands double tax treaty of 29 January $2002 .{ }^{378}$

${ }^{378}$ Convention for Avoidance of Double Taxation and the Prevention of Fiscal Evasion with Respect to Taxes on Income, the NetherlandsIndonesia (29 January 2002, entered into force 1 January 2004), art 10(2). 


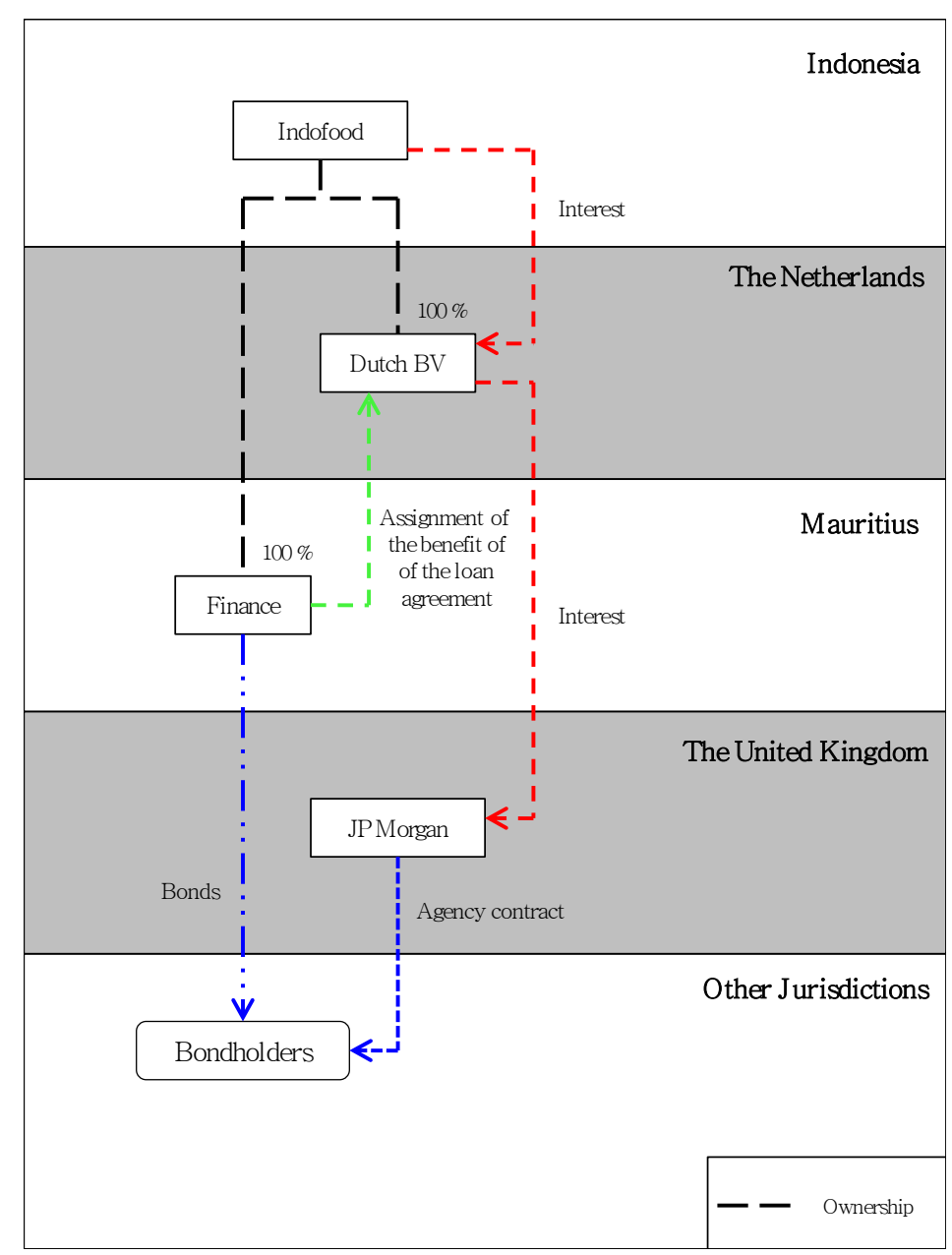

Figure 5.2: The Indofood case - the proposed structure

When Indofood sought the advice of the Director General of Taxes in Indonesia on the issue of whether Dutch BV would be recognised as the beneficial owner under the Indonesia-Netherlands double tax treaty, he replied in the negative. Subsequently, in a circular, he defined beneficial owner as follows: ${ }^{379}$

"Beneficial owner" refers to the actual owner of income such as Dividend, Interest, and or Royalty either individual taxpayer or business entity taxpayer that has the full privilege to directly benefit from the income.

As a result, a dispute arose between Indofood and JP Morgan over a "reasonable measure", and the matter went to the Court of Appeal in the United Kingdom. In order to

${ }^{379}$ Indofood International Finance Ltd v JP Morgan Chase Bank NA, London Branch, above n 375, at para19 (emphasis added). 
determine whether establishing Dutch BV was a "reasonable measure", the court investigated whether Dutch BV could be considered the beneficial owner of the interest payments from Indofood under the IndonesiaNetherlands double tax treaty. The court held that Dutch $\mathrm{BV}$ could not be regarded as the beneficial owner of the interest, and therefore, the option of establishing Dutch BV was not a reasonable measure.

\subsection{Indofood: the presence of a contractual obligation and beneficial ownership}

On evaluating the facts in the light of the definition of "beneficial owner" accorded by the Director General, the court was of the opinion that "the legal, commercial and practical structure behind the loan notes" 380 was inconsistent with the concept that Finance or Dutch BV could enjoy the full privilege to benefit directly from the income.

The court began with an examination of the legal structure and found that Finance was bound to pay to JP Morgan the interest it received from Indofood because conditions of the loan notes precluded it from funding the money from any other source. Dutch BV was likely to be bound by same conditions. Essentially, the court found that Finance was so bound and that Dutch BV would be contractually obliged to pass on its income to JP Morgan. It did not, however, consider this finding to be conclusive. The court was of the opinion that: ${ }^{381}$

... the meaning to be given to the phrase "beneficial owner" is plainly not to be limited by so technical and legal an approach. Regard is to be had to the substance of the matter.

${ }^{380}$ Indofood International Finance Ltd v JP Morgan Chase Bank NA, London Branch, above n 375, at para 43.

${ }^{381}$ Ibid, at para 44. 
For this reason, it focused on investigating the commercial and practical structure behind the loan notes.

The court noted that, after the first interest payment to Finance, Indofood had been paying interest directly to JP Morgan. In its opinion, Indofood was bound to ensure that such an arrangement continued lest it was required to pay again under its guarantee to the note holders. It further found that in practical terms Finance or Dutch BV could not have used the interest payments for any other purpose except for funding its liability to JP Morgan. It did not consider Finance and Dutch BV to have the "full privilege" needed to qualify as the beneficial owner just because they could fund their liability to JP Morgan. It, therefore, equated the position of Finance and Dutch BV to that of an "administrator of the income". ${ }^{382}$ The court found this conclusion to be consistent with the object and purpose of the Indonesian double tax agreements with Mauritius and the Netherlands. ${ }^{383}$

The point that emerges is that the court interpreted differently the term "beneficial owner" for legal purposes and for purposes of double tax agreements. The court regarded the criterion of the presence of a contractual obligation to pass on passive income as an indicator of beneficial ownership for legal purposes. Since it was concerned with the interpretation of "beneficial owner" for the purposes of Indonesian double tax agreements with Mauritius and the Netherlands, it regarded the simple presence of a contractual obligation as indecisive.

Further, when determining whether Indofood was, and Dutch BV would be, the beneficial owner under the double

${ }^{382}$ Indofood International Finance Ltd v JP Morgan Chase Bank NA, London Branch, above n 375, at para 44.

${ }^{383}$ Ibid, at para 45. 
tax treaties in question, the court examined the substance of the arrangement in the light of the object and purpose of the treaties.

The approach of courts in the Bank of Scotland case and the Indofood case shows that the main issue in conduit company cases is whether the arrangement is consistent with the object and purpose of a double tax agreement. The issue requires a substantive economic approach. It cannot be resolved solely on the basis of the presence of an obligation to pass on passive income, whether in property law or in contract law.

Nevertheless, paragraph 14(b) of the Conduit Companies Report ${ }^{384}$ considers the main issue in a conduit company case to be whether a recipient company is obliged to pass on passive income, particularly under property law. That is, it treated dominion as a sufficient criterion for deciding conduit company cases. As indicated in section 5.4, a reason for paragraph 14(b) to adopt this approach is its reference to the official commentary on Articles 10, 11 and 12 of the OECD Model Convention of 1977, which presented a "nominee or agent" as an example of conduits.

This official commentary has not only misled paragraph 14(b), but also misdirected courts in the Royal Dutch Shell case ${ }^{385}$ and Prévost Car Inc v Her Majesty the Queen. ${ }^{386}$ The following sections examine the reasoning in these cases.

\footnotetext{
${ }^{384}$ OECD Committee on Fiscal Affairs "Double Taxation Conventions and the Use of Conduit Companies" in OECD Committee on Fiscal Affairs International Tax Avoidance and Evasion: Four Related Studies, Issues in International Taxation No 1 (OECD, Paris, 1987) 87 at para 14(b).

385 For example Royal Dutch Shell (6 April 1994) Case no 28 638, BNB 1994/217 (the Hoge Raad, the Netherlands).

${ }^{386}$ Prévost Car Inc v Her Majesty the Queen (2008) TCC 231.
} 


\subsection{The example of a "nominee or agent" as conduit: a fallacy}

Because the official commentary used a "nominee or agent" as an example of conduits, it misdirects courts on two different, though related, issues.

First, the commentary implied that cases concerning nominees and agents involve an issue of beneficial ownership. That is, it implied that in some cases nominees or agents can be entitled to treaty benefits. The implication does not make sense. In cases involving agents and nominees, property is vested solely in the person on whose behalf they work. It follows that passive income originates from a source company as the property of a company that is resident in a third state. That is, nominees or agents fundamentally do not own passive income. For this reason, nominees or agents should not be able to qualify for treaty benefits on any criterion.

The official commentary on Articles 10 and 11, as it stands after its amendment in 2003, has overcome this shortcoming to a large extent. It states: ${ }^{387}$

Where an item of income is received by a resident of a Contracting State acting in the capacity of agent or nominee it would be inconsistent with the object and purpose of the Convention for the State of source to grant relief or exemption merely on account of the status of the immediate recipient of the income as a resident of the other Contracting State. The immediate recipient of the income in this situation qualifies as a resident but no potential double taxation arises as a consequence of that status since the recipient is not treated as the owner of the income for tax purposes in the State of residence.

387 OECD Committee on Fiscal Affairs "Commentary on Article 10 concerning the Taxation of Dividends" (OECD, Paris, 2010) in OECD Committee on Fiscal Affairs Model Tax Convention on Income and on Capital (OECD, Paris, 2010) 187 at para 12.1. OECD Committee on Fiscal Affairs "Commentary on Article 11 concerning the Taxation of Interest" (OECD, Paris, 2010) in OECD Committee on Fiscal Affairs Model Tax Convention on Income and on Capital (OECD, Paris, 2010) 211 at para 10 . 
It is obvious that the commentary has clarified that, because nominees or agents, by definition, do not own income, no potential double taxation arises. For this reason, it becomes redundant to ask the question of whether a "nominee or agent" is the beneficial owner of passive income.

Second, the official commentary on Articles 10, 11 and 12 of the OECD Model Convention of 1977 suggested that the presence of dominion also justifies treating the property as being held by someone who is not a conduit. That is, it implied that an immediate recipient that exercises dominion over property necessarily qualifies for treaty benefits, or an immediate recipient that does not act in the capacity of a nominee or agent necessarily qualifies for treaty benefits.

The decision of the Hoge Raad of 6 April $1994,{ }^{388}$ also known as the Royal Dutch Shell case, is an example of such a misinterpretation. This case concerns the application of Article 10(2) of the Netherlands-United Kingdom double tax treaty of 7 November $1980 .{ }^{389}$ Although the Hoge Raad did not refer to the official commentary on Article 10(2) of the OECD Model Convention of 1977, the Attorney General, who agreed with the court, relied on it. Further, Article 10(2) of the Netherlands-United Kingdom double tax treaty was the same as Article 10(2) of the OECD Model Convention of 1977. ${ }^{390}$ For this reason, the case can be treated as relevant in the present context.

\footnotetext{
388 Royal Dutch Shell (6 April 1994) Case no 28 638, BNB 1994/217 (the Hoge Raad, the Netherlands).

${ }^{389}$ Convention for the Prevention of Fiscal Evasion with respect to Taxes on Income and Capital Gains, the Netherlands-the United Kingdom (07 November 1980), art 10(2).

390 "Conclusie Advocaat-Generaal mr. Van Soest" in Royal Dutch Shell, above n 337, para 4.5.
} 


\subsection{Royal Dutch Shell}

Luxembourg SA, a holding company resident in Luxembourg, owned some shares of Royal Dutch Shell, a Dutch corporation. Royal Dutch Shell declared dividends. Soon after the dividends were declared, but before they were made payable, X Ltd, a stockbroker company resident in the United Kingdom, bought coupons for dividends on the shares from Luxembourg SA.

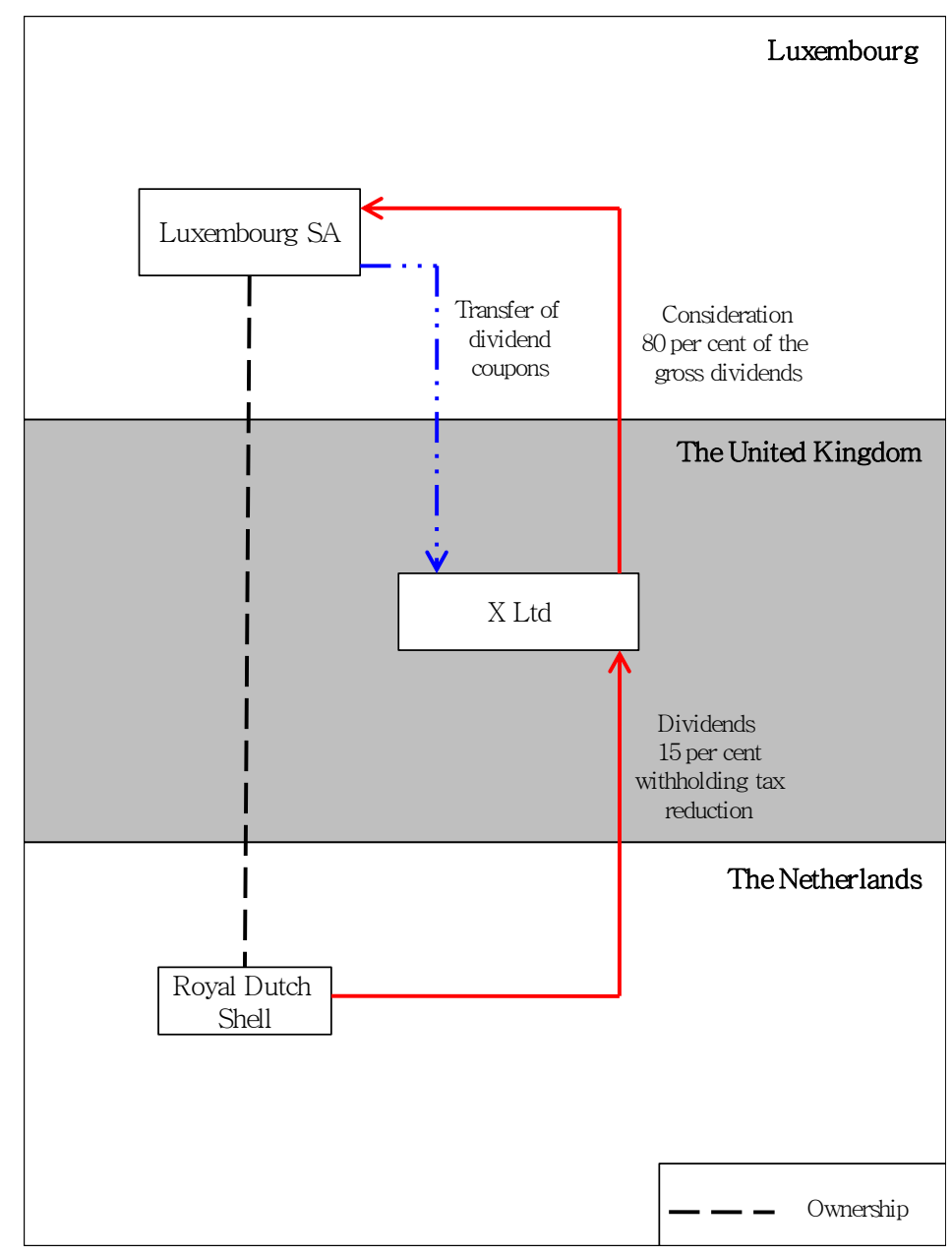

Figure 5.3: The Royal Dutch Shell case

The purpose of the arrangement was to obtain a 10 per cent withholding tax reduction under Article 10(2) of the double tax treaty between the Netherlands and United Kingdom. $^{391}$ The Netherlands-Luxembourg double tax 
treaty of $1968^{392}$ would have offered a withholding tax exemption to Luxembourg SA at the same rate; however, Luxembourg SA was not entitled to a withholding tax reduction because it was a holding company within the meaning of the Luxembourg holding company law of $1929^{393}$ and was therefore subjected to Dutch withholding tax at the rate of 25 per cent.

When the dividend was available for payment, X Ltd cashed the coupons. The paying agent of the dividend withheld Dutch withholding tax at the rate of 25 per cent. X Ltd applied to the Dutch tax authority for a partial refund of the withholding tax on the basis of Article 10 of the Netherlands-United Kingdom double tax treaty. ${ }^{394}$ The Dutch tax inspector denied the refund, arguing that X Ltd was not the beneficial owner.

The Hoge Raad held that X Ltd was the beneficial owner. Explaining its reasons for considering X Ltd to be the beneficial owner, it observed (author's translation): $:^{395}$

[X Ltd] became [the] owner of the dividend coupons as a result of purchase thereof. [It] can further be assumed

provides, "... dividends may be taxed in the State of which the company paying the dividends is a resident, and according to the law of that State, but where such dividends are beneficially owned by a resident of the other State the tax so charged shall not exceed:

(b) ... 15 per cent of the gross amount of the dividends."

${ }^{392}$ Convention for the Avoidance of Double Taxation and the Prevention of Fiscal Evasion with respect to Taxes on Income and Fortune, the Netherlands-Luxembourg (8 May 1968, entered into force 20 October 1969), art 10(2)(b).

393 Loi du juillet 1929 sue le regime fiscal des societies de participations financiers 1929 (Luxembourg).

${ }^{394}$ The Netherlands-United Kingdom double tax treaty of 7 November 1980, above n 389, art 27(6).

395 "Beoordeling van de middelen van cassatie" in Royal Dutch Shell, above n 388, para 3.2 (emphasis added). See also Stef van Weeghel The Improper Use of Tax Treaties: with Particular Reference to the Netherlands and the United States (Kluwer, London, 1998) at 76 (emphasis added). 
that subsequent to the purchase [X Ltd] could freely avail itself of those coupons and, subsequent to the cashing, could freely avail itself of the distribution, and in cashing the coupons [X Ltd] did not act as a voluntary agent of or for the account of the principal.

Under these circumstances the taxpayer is the beneficial owner of the dividend.

The freedom to avail oneself of property corresponds to the liberty to use property. The liberty to use property constitutes dominion over property, as discussed in section 5.1. Dominion is a characteristic of ownership. The Hoge Raad seems to assume that X Ltd could "freely avail itself" of the distribution after cashing the dividend coupons because $\mathrm{X}$ Ltd did not act as a nominee or agent when cashing them. X Ltd did not act in the capacity of a nominee or agent because it was the legal owner by virtue of buying them. Effectively, the court treated the freedom to avail oneself of property as a characteristic of ownership. The freedom to avail oneself of property, therefore, can be equated to dominion.

The observation shows that the court regarded the presence of dominion as an indicator of beneficial ownership. In essence, the Hoge Raad's reasoning was as follows: because X Ltd had the ownership, it had the dominion and therefore, it did not act in the capacity of "nominee or agent"; and because X Ltd was not a "nominee or agent", it was the beneficial owner. Effectively, the court considered the presence of dominion to be sufficient to determine whether X Ltd was the beneficial owner.

The court seems to commit an error of logic known as "denying the antecedents" or "inverse error". The fact that a person acts in the capacity of a "nominee or agent" implies that the person is not the beneficial owner for the purpose of double tax treaties. However, if a person does not act in the capacity of a "nominee or agent", he does 
not necessarily qualify as the beneficial owner for the purpose of double tax treaties. The approach of Lord Justice Chadwick in the Indofood case lends support to this argument. As discussed in section 5.9, the court in the Indofood case was concerned with the issue of whether the proposed Dutch corporation, Dutch BV, would be regarded as the beneficial owner under the double tax treaty between Indonesia and the Netherlands. Lord Justice Chadwick observed: ${ }^{396}$

The fact that neither [Finance] nor [Dutch BV] was or would be a trustee, agent or nominee for the noteholders or anyone else in relation to the interest receivable from Indofood is by no means conclusive.

The foregoing analysis illustrates that the use of a "nominee or agent" as an example of a conduit has misled courts to apply the dominion test to conduit company cases.

\subsection{Reasons for the existence of X Ltd}

As discussed in section 5.5, because a nominee or agent does not have dominion over income, a mandatory or principal receives the income as it originates. The Hoge Raad decided Royal Dutch Shell on the basis of the dominion test and it was probably misled by the fact that Luxembourg SA received a price paid for the dividend, not the dividend. The difference in the character of income was purely formal.

Because Luxembourg SA was a 1929 holding company, it was liable to pay the Netherlands statutory withholding tax at 25 per cent on the dividend payment it would have received from Royal Dutch Shell. That is, had Luxembourg SA received dividends directly from Royal Dutch Shell, it would have received 75 per cent of the

\footnotetext{
${ }^{396}$ Indofood International Finance Ltd v JP Morgan Chase Bank NA, London Branch [2006] EWCA Civ 158, at para 42.
} 
gross dividends. The price at which Luxembourg SA sold dividend coupons to $\mathrm{X}$ Ltd was 80 per cent of the gross dividends. In effect, Luxembourg SA avoided five per cent of the Netherlands statutory withholding tax. Subsequently, when $X$ Ltd received a 15 per cent withholding tax reduction under the Netherlands-United Kingdom double tax treaty, it gained a profit of five per cent.

In substance, $\mathrm{X}$ Ltd does not seem to have had any reasons for existence except to enable Luxembourg SA to obtain a tax benefit by taking advantage of the Netherlands-United Kingdom double tax treaty. It acted as a conduit that earned five per cent profit in the process of passing on dividends from Royal Dutch Shell to Luxembourg SA. ${ }^{397}$

The arrangement in the Royal Dutch Shell case resembles the arrangement in the Bank of Scotland case. In both cases, when passive income arose, recipient companies were neither contractually bound nor obliged in property law to pass the income on to resident companies. Further, the recipient companies were unrelated to companies in the source and resident states. Nevertheless, the courts came to opposite conclusions because their approach differed. While the court in the Bank of Scotland ${ }^{398}$ case evaluated the effect of the arrangement, the court in the Royal Dutch Shell case based its decision on the criterion of the presence of dominion.

The Royal Dutch Shell case shows that the application of the dominion test leads a court to analyse facts from a company law perspective, rather than from a substantive

\footnotetext{
397 See also Herman Born "Beneficial Ownership: Decision of the Netherlands Supreme Court of 6 April 1994” (1994) ET 469, at 472.

${ }^{398}$ Ministre de l'Economie, des Finances et de l'Industrie v Société Bank of Scotland (2006) 9 ITLR 683, at 703.
} 
economic perspective. As a consequence, it focuses on a criterion that an intermediary possesses by definition, and ignores factors that may help it to determine whether the arrangement is consistent with the object and purpose of a double tax agreement. Although this point emerges as an implication of the Hoge Raad's reasoning in the Royal Dutch Shell case, it is illustrated directly by the reasoning of the Tax Court of Canada in Prévost Car Inc. v Her Majesty the Queen. ${ }^{399}$

\subsection{The Prévost Car case}

The Prévost Car case involved Volvo, a Swedish company, and Henlys, a company resident in the United Kingdom. They entered into a "shareholders' and subscription" agreement under which they incorporated Dutch BV in the Netherlands in order to acquire shares of Prévost, a Canadian company. Dutch BV was not a party to the agreement. Volvo owned the majority of shares in Dutch BV.

\footnotetext{
399 Prévost Car Inc v Her Majesty the Queen (2008) TCC 231 (Tax Court of Canada, Canada).
} 


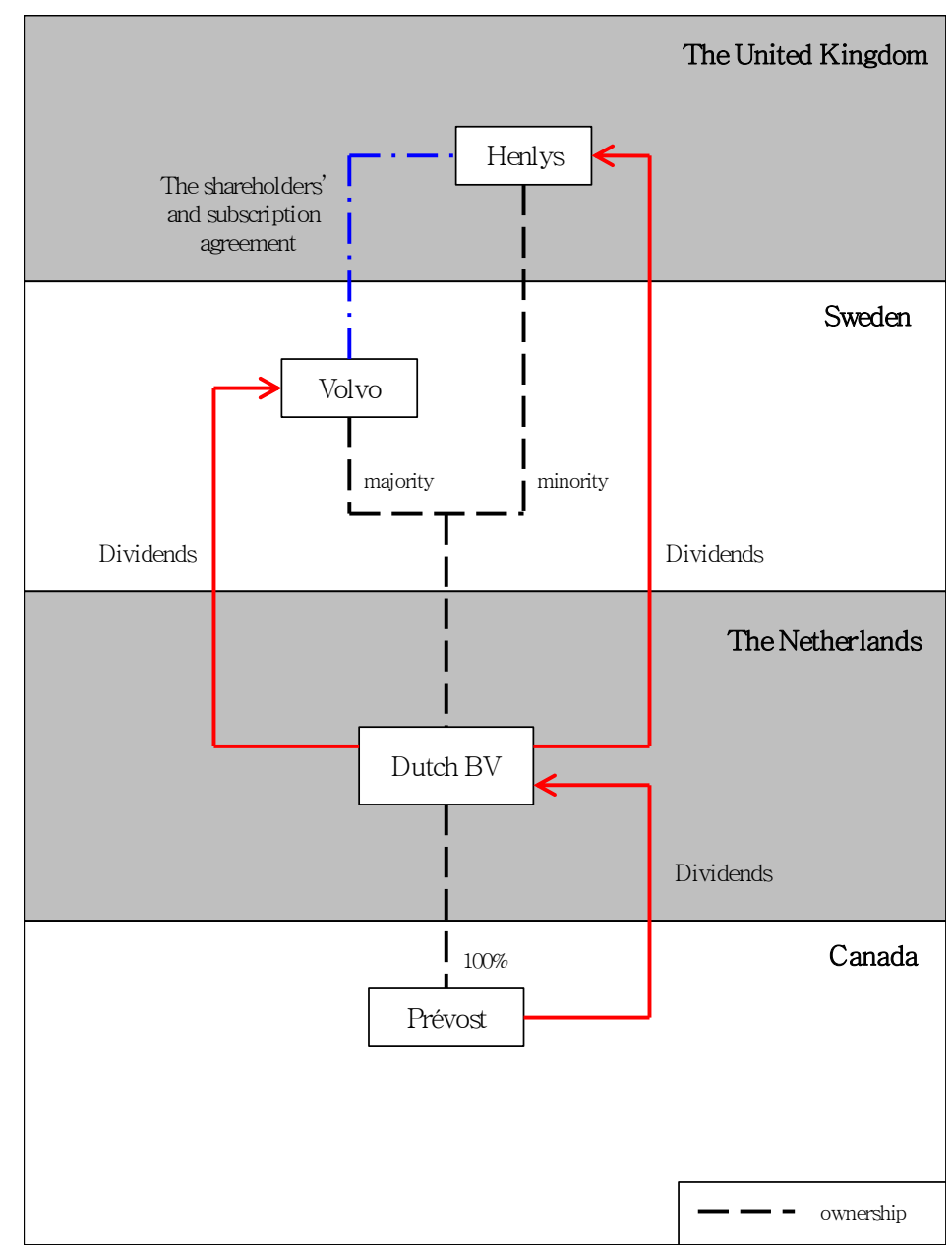

Figure 5.4: The Prévost Car case

Dutch BV had no physical office or employees. It had the same directors as Prévost. It executed a power of attorney in favour of a Dutch management company, TIM, to carry out its business transactions and to pay interim dividends on its behalf to Volvo and Henlys.

According to the shareholders' and subscription agreement, at least 80 per cent of profits of Prévost and Dutch BV were to be distributed to Volvo and Henlys. It provided that the board of directors of Dutch BV would take reasonable steps to procure dividends and other payments from Prévost to enable Dutch BV to pay dividends to Volvo and Henlys.

Prévost paid dividends to Dutch BV and Dutch BV distributed them to Volvo and Henlys. Prévost deducted 
five per cent withholding tax from dividend payments in accordance with Article 10(2) of the Canada-Netherlands double tax treaty of 4 March $1993 .{ }^{400}$ The Canadian Minister of National Revenue issued assessment notices with respect to the payments on the basis that Volvo and Henlys were their beneficial owners.

The Tax Court of Canada held that Dutch BV was the beneficial owner of the dividend payments from Prévost. The Federal Court of Appeal confirmed its decision. ${ }^{401}$

\subsection{Prévost Car: dominion an indicator of beneficial ownership}

The Tax Court of Canada referred to the official commentary on Article 10(2) of the OECD Model Convention of $1977 .^{402}$ Although the court acknowledged that the official commentary was amended in 2003, it did not note the change in the commentary with respect to nominees and agents. ${ }^{403}$ Further, the court referred to paragraph 14(b) of the Conduit Companies Report, which itself relies on the official commentary of the relevant provisions of the OECD Model Convention of 1977 for transposing the dominion test from cases involving nominees or agents to conduit company cases. ${ }^{404} \mathrm{~A}$ possible reason for the court to refer to paragraph 14(b) is that the OECD Committee on Fiscal Affairs incorporated the paragraph in the official commentary in 2003.

\footnotetext{
${ }^{400}$ Protocol to the Convention for Avoidance of Double Taxation and the Prevention of Fiscal Evasion with Respect to Taxes on Income, Canada-the Netherlands (4 March 1993, entered into force 30 July 1994).

${ }^{401}$ Her Majesty the Queen v Prévost Car Inc 2009 FCA 57 (Federal Court Of Appeal, Canada).

${ }^{402}$ Prévost Car Inc v Her Majesty the Queen, above n 399, at para 31.

${ }^{403}$ Ibid, at para 32.

${ }^{404}$ Ibid.
} 
Nevertheless, the point is that when discussing the meaning of the term "beneficial owner", the Tax Court was influenced by the official commentary on Article 10(2) of the OECD Model Convention of 1977, which used a "nominee or agent" as an example of conduits. The court observed: ${ }^{405}$

... the 'beneficial owner' of dividends is the person who receives the dividends for his or her own use and enjoyment and assumes the risk and control of the dividend he or she received. The person who is [the] beneficial owner of the dividend is the person who enjoys and assumes all the attributes of ownership. In short the dividend is for the owner's own benefit and this person is not accountable to anyone for how he or she deals with the dividend income ... It is the true owner of property who is the beneficial owner of the property. Where an agency or mandate exists or the property is in the name of a nominee, one looks to find on whose behalf the agent or mandatary is acting or for whom the nominee has lent his or her name. When corporate entities are concerned, one does not pierce the corporate veil unless the corporation is a conduit for another person and has absolutely no discretion as to the use or application of funds put through it as [a] conduit, or has agreed to act on someone else's behalf pursuant to that person's instructions without any right to do other than what that person instructs it ...

Because the court considered the characteristic of being non-accountable to anyone for dealing with income to be an attribute of ownership, that attribute can be equated to dominion. The observation shows that the court regarded the presence of dominion as an indicator of beneficial ownership. Two points emerge.

First, the case involved a conduit company scheme. Nevertheless, the court applied the dominion test to the case because it equated the function of conduit companies with the role of nominees and agents.

Second, as a result of applying the dominion test the court compared the beneficial ownership test to the

\footnotetext{
${ }^{405}$ Prévost Car Inc v Her Majesty the Queen, above n 399, at para 100 (emphasis added).
} 
doctrine of piercing the corporate veil, and therefore, analysed the facts from the perspective of company law.

The next two sections will discuss these points separately.

\subsection{Prévost Car: analogy between nominees and agents, and conduit companies}

As with paragraph 14(b) of the Conduit Companies

Report, the court drew an analogy between nominees and agents on one hand, and conduit companies on the other. It seemed to compare the two categories on the basis that they "act on someone else's behalf pursuant to that person's instructions", 406 and therefore, have "no discretion as to the use or application of funds". ${ }^{407}$ In this manner, the court transposed the dominion test from cases involving nominees and agents to the present case, which was a conduit company case. It observed: ${ }^{408}$

However, there is no evidence that the dividends from Prévost were ab initio destined [to] Volvo and Henlys with [Dutch BV] as a funnel of flowing dividends from Prévost ... There was no predetermined or automatic flow of funds to Volvo and Henlys ...

The use of phrases "ab initio destined" and "predetermined or automatic flow" shows that the court examined the facts on the basis of a criterion that generally exists in a case involving a nominee or agent. That is, the court applied the reasoning of a case of a nominee or agent to a conduit company case.

As discussed in section 5.5, in cases involving a nominee or agent, income originates as the property of a person on whose behalf the nominee or agent receives it. That is, the income is ab initio destined to reach that

\footnotetext{
406 Prévost Car Inc v Her Majesty the Queen, above n 399, at para 102.

407 Ibid.

${ }^{408}$ Ibid, at para 102 (emphasis added).
} 
person in the form in which it arises. In conduit company cases, on the other hand, passive income originates as the property of the recipient company. When the recipient company passes the income on to a company that is resident in a third state, it does so in the capacity of the legal owner of the income. Because the recipient company is the legal owner of the income, unlike a nominee or agent, it has dominion over its income and is not obliged in property law to pass on the income. That is, as a legal owner, the recipient company may opt not to pay to the resident company. The point is that although from a substantive economic point of view a conduit company passes on the income that it received, in a formal legalistic sense the income cannot be regarded as ab initio destined to the resident of a third country. This point of difference makes it illogical to assume that in conduit company cases passive income is ab initio destined to reach to the resident company.

\subsection{Prévost Car: analogy between the beneficial ownership test and piercing the corporate veil}

As discussed earlier, the word "beneficial" is hard to apply to a corporation in any substantive sense because a corporation is a creation of the law. An apparently similar kind of problem arises in cases where the issue is whether the court should pierce the corporate veil; that is, cases in which the question before the court is whether a company should be treated as a wholly independent legal person or whether the court should look through the veil of incorporation and determine the economic substance of the company or its transaction. While this issue prima facie resembles the question of whether a company is the beneficial owner of passive income that it receives, it is essentially a different question. 
When applying the doctrine of piercing the corporate veil, courts analyse facts from a perspective of company law. By contrast, the application of the beneficial ownership test requires courts to investigate facts for tax purposes. Nevertheless, courts proceed on the basis that tests appropriate to situations when the law can pierce the corporate veil can logically be applied to determine whether a company is indeed a beneficial owner of income that it receives. The Prévost Car case is a good example.

Because the court in the Prévost Car case applied the dominion test to Dutch $\mathrm{BV}$, it determined the issue of whether Dutch BV was the legal owner, rather than whether Dutch BV was the substantive economic owner. That is, the court applied the beneficial ownership test from a legal perspective. As a result, the court seems to have mistaken disregarding the separate entity for tax purposes for lifting of the corporate veil.

The court analysed the facts of the case from the perspective of company law, and therefore regarded Dutch $\mathrm{BV}$ as a separate entity that exercised dominion over the income. It observed: ${ }^{409}$

[Dutch BV] was a statutory entity carrying on business operations and corporate activity in accordance with the Dutch law under which it was constituted ...

[Dutch BV] was the registered owner of Prévost shares. It paid for the shares. It owned the shares for itself. When dividends are received by [Dutch BV] in respect of shares it owns, the dividends are the property of [Dutch BV]. Until such time as the management board declares an interim dividend and the dividend is approved by the shareholders, the monies represented by the dividend continue to be property of, and [was] owned solely by, [Dutch BV]. The dividends are an asset of [Dutch BV] and are available to its creditors, if any. No other person other than [Dutch BV] has an interest in the dividends received from Prévost. [Dutch BV] can use the dividends as it wishes and is not accountable to its

${ }^{409}$ Prévost Car Inc v Her Majesty the Queen, above n 399, at para 103. 
shareholders except by virtue of the laws of the Netherlands.

The observation shows that the court tested Dutch BV against a criterion that Dutch BV possessed by definition, which was dominion over dividends. It, therefore, found Dutch BV to be the beneficial owner. However, the court asked the wrong question. As discussed in section 5.6 in the context of the Bank of Scotland case, the main issue in conduit company cases should be whether the arrangement is consistent with the object and purpose of a double tax agreement. For determining this issue, courts should analyse the facts with the objective of finding substantive economic reasons for the existence of Dutch BV in the corporate structure. It is therefore worth applying the reasons for the existence approach to examine whether Dutch BV was the beneficial owner of the dividends.

\subsection{Reasons for the existence of Dutch BV}

The court found that the dividends were not "ad initio destined"410 for Volvo and Henlys. It also found that no person other than Dutch BV had an interest in the dividends received from Prévost. ${ }^{411}$ As a matter of economic substance, these findings are questionable. On an analysis of the arrangement in the light of the object and purpose of double tax treaties, it is hard to conclude that there were reasons for Dutch BV's existence other than to pass on dividends from Prévost to Volvo and Henlys.

As discussed in section 5.14, under the shareholders' and subscription agreement, Volvo and Henlys, between them, were entitled to a minimum of 80 per cent of the

\footnotetext{
${ }^{410}$ Prévost Car Inc v Her Majesty the Queen, above n 399, at para 102.

${ }^{411}$ Ibid, at para 103.
} 
profits each of Prévost and Dutch BV. The agreement provided that the directors of Dutch BV, who were also the directors of Prévost, would ensure that Prévost would declare dividends so that Dutch BV could pay dividends to Volvo and Henlys. It could, therefore, be inferred that Dutch BV passed on what it received from Prévost.

This inference is strengthened by the facts that Dutch BV had no office or employees. Its only activity appeared to be to make dividend payments to Volvo and Henlys for which it mandated a management company. The court did not find evidence regarding the type of business activity Dutch BV carried out.

Together, these facts show that Dutch BV acted as a conduit and therefore that the arrangement it was involved in was inconsistent with the object and purpose of the double tax agreement in question.

Nevertheless, the court accorded no significance to these facts. It observed: ${ }^{412}$

There is no evidence that [Dutch BV] was a conduit for Volvo and Henlys. It is true that [Dutch BV] had no physical office or employees in the Netherlands or elsewhere. It also mandated to TIM the transaction of its business as well for TIM to pay interim dividends on its behalf to Volvo and Henlys...

... [Dutch BV] was not party to the shareholders' agreement; neither Henlys nor Volvo could take action against [Dutch BV] for failure to follow the dividend policy described in the shareholders' agreement ....

... I cannot find any obligation in law requiring [Dutch BV] to pay dividends to its shareholders on a basis determined by the shareholders' agreement. When [Dutch BV] decides to pay dividends it must pay the dividends in accordance with Dutch law.

The observation shows that the court examined the shareholders' and subscription agreement in order to determine whether Dutch BV was contractually obliged to pass on dividends. That is the court focused on the issue of

${ }^{412}$ Prévost Car Inc v Her Majesty the Queen, above n 399, at para 102. 
whether Dutch BV was under an obligation to pass on dividends, which as discussed in section 5.7 is indecisive for solving conduit company cases. The fact that an interposed company is not under an obligation to pass on dividends cannot logically lead to the conclusion that that company is not a conduit.

\subsection{Conclusion}

Dominion may be helpful for deciding cases involving nominees and agents; however, since it is a concept that is used in a formal legalistic sense it cannot logically determine an issue that, under the policy of double tax agreements, is a matter of substance. As a result of applying the dominion test to conduit company cases, courts have evaluated facts from a formal legalistic point of view, rather than adopting a substantive economic approach.

The reasoning of courts in Royal Dutch Shell and Prévost Car illustrate that by treating the dominion test as decisive, courts effectively ask the question whether the immediate recipient was a nominee or agent. Since they find that the immediate recipient is not a nominee or agent, they conclude that the immediate recipient is not a conduit. This reasoning, however, does not make sense. A company that immediately receives passive income can be a conduit without being a nominee or agent.

The absence of dominion shows that an intermediary acts in the capacity of a nominee or agent, and therefore, is not entitled to treaty benefits. Such cases, however, do not involve an issue of beneficial ownership. In such cases, an intermediary possesses no ownership rights at all, and therefore, does not qualify for treaty benefits on any criterion. For this reason, it seems misleading to present a 
nominee or agent as an example of conduit in order to demonstrate the role of a conduit company.

Conduit companies are the legal owners of passive income. Generally, conduit companies tend to exploit their status as the legal owners to disguise their role, which is in effect no more than to pass on passive income. That is why double tax agreements require courts to differentiate legal ownership from substantive economic ownership. Because dominion indicates no more than legal ownership, it cannot be decisive by itself for deciding conduit company cases. 


\section{CHAPTER 6 \\ THE STEP TRANSACTION DOCTRINE}

6. The Step transaction doctrine ............................ 219

6.1. Introduction .................................................. 220

6.2. The step transaction doctrine ............................ 222

6.3. The binding commitment test ........................... 224

6.4. The end-result test.......................................... 224

6.5. The mutual-interdependence test ....................... 226

6.6. The Del Commercial case ................................. 226

6.7. Del Commercial: a comparison with the Northern Indiana case .................................................... 229

6.8. Del Commercial: the step transaction doctrine.... 231

6.9. Del Commercial: the step transaction doctrine and beneficial ownership ....................................... 232

6.10. The $W$-family 1 case ....................................... 234

6.11. $W$-family 1: the step transaction doctrine ........... 236

6.12. W-family1: link between transactions and tax avoidance.................................................... 238

6.13. W-family 1 : the step transaction doctrine and beneficial ownership ...................................... 238

6.14. Link between transactions: an indecisive approach arrangement as a whole? ................................... 241

6.16. The Indofood case .......................................... 242

6.17. Del Commercial: narrow and technical approach 245

6.18. The SDI Netherlands case ................................. 246

6.19. The "flow-through characterisation concept"..... 248

6.20. The "flow-through characterisation concept" and link between transactions .................................. 250

6.21. The "flow-through concept" and the "conduit concept": an analogy ....................................... 251

6.22. The court's interpretation of Aiken Industries and Northern Indiana ............................................. 253

6.23. Similarity in terms and conditions .................... 254

6.24. Close relationship.......................................... 255

6.25. Reasons for existence of SDI Netherlands .......... 257

6.26. $W$-family 1 : deviation from the reasons for existence approach ...................................................... 258

6.27. The Y-group 1990 case................................... 259

6.28. W-family 1 : did the court consider the arrangement in its entirety? .............................................. 260

6.29. The $W$-family 2 case ....................................... 261

6.30. The $X$-group 1979 case .................................. 265

6.31. Consideration of the arrangement as a whole...... 267

6.32. Reasons for the existence of Antillean NV ......... 268

6.33. Conclusion........................................................ 270 


\subsection{Introduction}

The United States courts developed the step transaction doctrine in their domestic tax jurisdiction as a variation of the substance over form approach. When the United States courts apply the step transaction doctrine to a series of transactions, they integrate the individual steps into a single transaction. They apply the step transaction doctrine if they find that the individual steps are so interlinked that they could be treated as a part of an overall plan. The doctrine migrated to conduit company cases in Del Commercial Properties Inc v Commissioner of Internal Revenue. ${ }^{413}$ Interestingly, the Dutch courts have adopted the same approach in certain conduit company cases. ${ }^{414}$ Because they have not assigned a particular term to their approach, for the convenience of reference, this chapter will refer to it also as "the step transaction doctrine".

The United States and Dutch courts adopted the step transaction doctrine for deciding certain conduit company cases in which parties transferred income generating assets via back-to-back transactions from the country of residence of a beneficial owner - the resident state - to the country of the origin of passive income, the source state. These transactions involved one or more interposed companies. They were designed to avoid withholding tax in the source state under the double tax treaty between it and the state where the interposed company was located.

In order to determine whether the company interposed in the other contracting state was entitled to treaty benefits, the courts investigated whether the individual

413 Del Commercial Properties Inc $v$ Commissioner of Internal Revenue TC Memo 411 (1999). Del Commercial Properties Inc v Commissioner of Internal Revenue 251 F 3d 210 (2001).

414 W-family 1 (18 May 1994) Case no 28 293, BNB 1994/252 (the Hoge Raad, the Netherlands), and $W$-family 2 (18 May 1994) Case no 28 296, BNB 1994/253 (the Hoge Raad, the Netherlands). 
transactions were so linked that they could be treated as a part of a single transaction. Since they found that the transactions were interlinked, they treated the series of transactions in substance as a transfer of the income generating assets from the resident state directly to the source state. Because this transaction in substance resulted in an avoidance of the source state withholding tax by residents of non-contracting states, the courts treated the interposed company as a conduit. That is, they did not consider the company to be the beneficial owner. Effectively the courts treated beneficial ownership as an anti-avoidance test, instead of treating it as a test of ownership. That is, they did not assign a strict linguistic meaning to beneficial ownership. To this extent, their approach corresponds to the "reasons for existence" approach.

However, the problem with their reasoning is that it narrows the scope of the step transaction doctrine. Consequently, it also restricts the scope of the beneficial ownership test. In order to decide whether the step transaction doctrine should be applied, the courts accorded undue significance to the presence of the link between those transactions only where the parties transferred the income generating assets from the ultimate owner to the source state. That is, unlike the reasons for existence approach, the approach of the courts did not involve an examination of the arrangement as a whole. As indicated in section 3.12, in addition to the flow of income generating assets, an arrangement includes factors such as the flow of passive income, business activities of interposed companies and their locations.

The step transaction doctrine should catch any arrangement that results in the flow of benefits of a double 
tax treaty to a resident of a non-contracting state. However, the approach adopted by the United States and Dutch courts restricted the application of the doctrine to the criterion of the presence of a link between transactions involving the transfer of income generating assets. Although the presence of a link between transactions may indicate that an immediate recipient does not act as a conduit, its absence does not necessarily show that the immediate recipient owns passive income beneficially.

Although the courts based their decision on the criterion of the presence of a link between transactions, their approach differs from the surrogate tests in two respects. First, unlike the surrogate tests, the step transaction doctrine does not treat beneficial ownership as a test of ownership. Second, the courts consider the link between transactions to be related inversely to beneficial ownership. By contract, when applying the surrogate tests, courts regarded the criteria by which the tests operate as positively related to beneficial ownership.

The proximity of the approach adopted by the United States and Dutch courts to the "reasons for existence" approach, and its contrast with the surrogate tests make this chapter revisit material from previous chapters, especially chapter 3 . Before discussing conduit company cases in which courts have used the step transaction doctrine, it is necessary to discuss the doctrine as it originated in the United States domestic tax jurisdiction.

\subsection{The step transaction doctrine}

When explaining the operation of the step transaction doctrine, the United States Supreme Court in Leonard 
Greene and Joyce Greene v United States of America ${ }^{415}$ observed: ${ }^{416}$

The doctrine treats the "steps" in a series of formally separate but related transactions involving the transfer of property as a single transaction, if all the steps are substantially linked ... Rather than viewing each step as an isolated incident, the steps are viewed together as components of an overall plan.

The United States courts apply the step transaction doctrine to cases where taxing the individual steps of a transaction rather than the transaction as a whole would undermine the substance of the transaction resulting in improper treatment of the whole transaction. ${ }^{417}$

Because in a conduit company scheme the beneficial owner is a resident of a third state, allowing a reduction in the source state withholding tax contradicts the object and purpose of the double tax agreement. Applying the step transaction doctrine to a conduit company scheme, a court treats an intermediary as a conduit and disregards steps that involve the transfer of passive income from a source to a resident company through the intermediary.

The United States courts adopt three tests for determining whether individual steps are "substantially linked". ${ }^{418}$ These tests are the "binding commitment" test, the "end-result" test, and the "mutual interdependence" test.

${ }^{415}$ Leonard Greene and Joyce Greene v United States of America $13 \mathrm{~F}$ 3d 577 (2d Cir 1994).

${ }^{416}$ Ibid at 583 (emphasis added).

${ }^{417}$ See Yoram Keinan "Rethinking the Role of the Judicial Step Transaction Principle and a Proposal for Codification" (2007) 22 Akron Tax J 45, at 48 .

${ }^{418}$ Leonard Greene and Joyce Greene v United States of America, above $\mathrm{n} 415$, at 583 . 


\subsection{The binding commitment test}

When using the "binding commitment" test, the United States courts invoke the step transaction doctrine only if the taxpayer was under a commitment to complete the remaining steps at the time the first step took place. ${ }^{419}$ Courts will not apply the doctrine if there was a moment during the transactions at which the parties were not under a binding obligation. ${ }^{420}$

The narrow scope of the test makes it easy for taxpayers to manipulate the result of the application of the test. $^{421}$ For this reason, the United States courts rarely apply it. In the light of the narrow scope of the test, one might expect that in conduit company cases, the courts would regard the presence of an obligation of an interposed company to pass on passive income as a binding commitment. As discussed in sections 5.5 and 5.7, even if an intermediary company is under no obligation to pass on passive income to a resident company, it can still act as a conduit, and therefore, can be involved in a transaction that is contrary to the object and purpose of a double tax agreement. For this reason, the test seems inappropriate for deciding conduit company cases.

\subsection{The end-result test}

Under the "end-result" test, the United States courts integrate separate steps if they find that the steps form part of a single scheme intended to achieve a single result. They do not recognise the individual steps as separate "unless the taxpayer shows that at the time the parties

\footnotetext{
${ }^{419}$ Commissioner of Internal Revenue v Gordon 391 Us 83 (1968) at 96.

${ }^{420}$ Long Term Capital Holdings v United States of America 330 F Supp 2d 122 (2004).

${ }^{421}$ See Robert A Penrod v Commissioner of Internal Revenue 88 TC 1415 (1987) at 1428 .
} 
engaged in the individual steps, its result was the intended end result in and of itself.",422

The end-result test focuses on the taxpayer's intent at the time of the first step. Thus, the parties' intent for each event is examined separately, and if the intent of the parties pertaining to a particular event is that such an event will merely serve as another step in achieving an endresult, the court will disregard the event. ${ }^{423}$

Under the end-result test, courts focus on the issue of whether a taxpayer intended to reach a particular result by structuring a series of transactions in a certain way, not on the issue of whether a taxpayer intended to avoid taxes. ${ }^{424}$

The United States courts have not applied the endresult test to conduit company cases. The approach adopted by the Dutch courts in $W$-family $1,{ }^{425}$ however, corresponds to the end-result test. As section 6.11 discusses, the court in $W$-family 1 regarded transactions as interlinked because it found that parties transferred shares to the immediate recipient with the intent that the company in the source state would buy them subsequently. For this reason, $W$ family 1 could be seen to provide an illustration of the application of the end-result test to conduit company cases; and the inferences drawn may be associated with the end-result test.

\footnotetext{
${ }^{422}$ Andantech LLC v Commissioner of Internal Revenue $83 \mathrm{TCM}(\mathrm{CCH})$ 1476 (2002) at 1504 (emphasis added).

${ }^{423}$ Long Term Capital Holdings $v$ United States of America, above $\mathrm{n}$ 420 , at 191 .

${ }^{424}$ Jean D. True v United States of America 190 F 3d 1165 (10th Cir 1999) at 1175.

${ }^{425}$ W-family 1 (18 May 1994) Case no 28 293, BNB 1994/252 at para 4.5 (the Hoge Raad, the Netherlands).
} 


\subsection{The mutual-interdependence test}

Pursuant to the "mutual-interdependence" test, courts apply the step transaction doctrine if "the steps are so interdependent that the legal relations created by one transaction would have been fruitless without a completion of the series". ${ }^{426}$ They examine whether the individual steps or events have independent significance or have meaning only as parts of the larger transaction. ${ }^{427}$

The United States Tax Court and the Court of Appeals for the District of Columbia applied the mutual interdependence test to Del Commercial Properties Inc $v$ Commissioner of Internal Revenue, ${ }^{428}$ which was a conduit company case. The tax planning scheme in this case involved a series of transactions by means of which the principal amount of a loan made by a Canadian bank was passed on to a United States company via different countries in order to avoid United States withholding tax on interest payments.

\subsection{The Del Commercial case}

Del Commercial $^{429}$ involved a group of affiliated companies with the following structure. DL Shekel, the parent company held all the shares of Tridel. Tridel wholly owned Delcom Financial, which in turn owned all the shares of Delcom Holdings. These companies were resident in Canada.

Delcom Holdings wholly owned Delcom Cayman, a company resident in the Cayman Islands. Delcom Cayman

\footnotetext{
${ }^{426}$ Redding $v$ Commissioner of Internal Revenue 630 F 2d 1169 (1980) at 1177 .

${ }^{427}$ See Robert A Penrod v Commissioner of Internal Revenue, above $\mathrm{n}$ 421 , at 1430 .

428 Del Commercial Properties Inc $v$ Commissioner of Internal Revenue TC Memo 411 (1999). Del Commercial Properties Inc v Commissioner of Internal Revenue 251 F 3d 210 (2001).

${ }^{429}$ Ibid.
} 
held all the shares of Delcom Antilles, an Antillean Corporation. Delcom Antilles in turn wholly owned a Dutch subsidiary, Del Netherlands. Delcom Holdings also owned all the shares of Del Commercial, a company resident in the United States, which was the taxpayer.

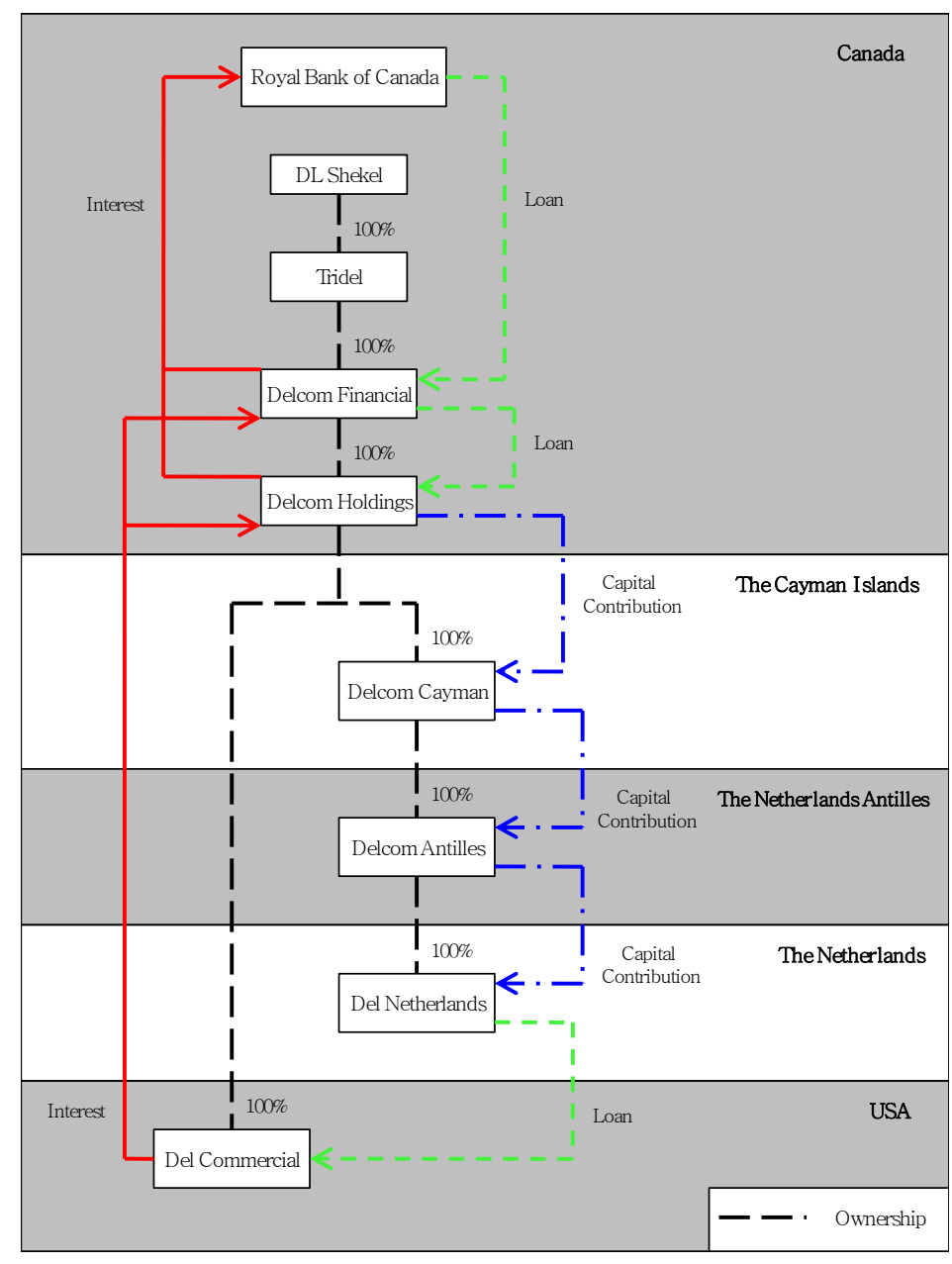

Figure 6.1: The Del Commercial case

Del Commercial was engaged in the business of leasing industrial real estate property and needed funds for its business. Tridel, therefore, arranged the following finance scheme. Delcom Financial borrowed money from Royal Bank of Canada and on-lent it to Delcom Holdings. The principal amount was then passed on to Delcom Netherlands through Delcom Cayman and Delcom Antilles by a series of similar transactions, which involved each intermediary contributing the principal amount to its 
wholly owned subsidiary in exchange for the subsidiary's common shares. Subsequently, Del Netherlands loaned the principal amount to Del Commercial. Del Netherlands had minimal assets, apart from the loan to Del Commercial. Del Netherlands was engaged in minimal business activity.

The interest rate and payment schedule of the loan made by Del Netherlands to Del Commercial were the same as the loan made by Bank of Canada to Delcom Financial. Del Commercial guaranteed repayment of the loan amount to the bank and authorised the bank to place a mortgage on its property in the United States.

Initially Del Commercial repaid the loan to Del Netherlands. Del Netherlands in turn transferred the payment to both Delcom Financial and Delcom Holdings, which forwarded the funds to the bank. However, after a year-and-a-half Del Commercial began repaying directly either to Delcom Holdings or to Delcom Financial, which forwarded the payments to the bank. Del Netherlands reported the interest paid by Del Commercial to Delcom Holdings and Delcom Financial on its tax returns.

The scheme was designed to obtain the United States withholding tax exemption on interest under Article VI of the United States-Netherlands double tax treaty of 29 April 1948. ${ }^{430}$ If Del Commercial had paid interest directly to Delcom Financial, it would have had to withhold tax at

\footnotetext{
430 Supplementary Convention Modifying and Supplementing the Convention with Respect to Taxes on Income and Certain other Taxes (30 December 1965, entered into force 8 July 1966), art VI. Article VI(1) stated: "Interest on bonds, notes, debentures, securities, deposits or any other form of indebtedness ... paid to a resident or corporation of one of the Contracting States shall be exempt from tax by the other Contracting State."
} 
the rate of 15 per cent under Article XI of the United States-Canada double tax treaty of 26 September $1980 .{ }^{431}$

Del Commercial did not withhold tax on interest payments. The Commissioner of Internal Revenue issued a notice of deficiency to Del Commercial on the grounds that the substance of the loan to it reflected a loan not from Del Netherlands, but from Delcom Financial, and therefore, the interest payments from Del Commercial should be treated as having been paid to Delcom Financial.

The United States Tax Court and the Court of Appeals for the District of Columbia Circuit decided in favour of the Commissioner.

\subsection{Del Commercial: a comparison with the Northern Indiana case}

Del Commercial argued that both courts should rely on the decision in Northern Indiana Public Service Company $v$ Commissioner of Internal Revenue, ${ }^{432}$ which the United States Tax Court and the Court of Appeals for Seventh Circuit had decided in favour of the taxpayer. It will be recalled from section 4.13 that, as with the present case, in the Northern Indiana case a United States company, Northern Indiana, borrowed funds from residents of third

431 Convention for the Avoidance of Double Taxation and the Prevention of Fiscal Evasion with respect to Taxes on Income and on Capital, Canada-United States (26 September 1980), art XI. Article XI (6)(a) states: "Interest arising in the United States that is contingent interest of a type that does not qualify as portfolio interest under United States law may be taxed by the United States but, if the beneficial owner of the interest is a resident of Canada, the gross amount of the interest may be taxed at a rate not exceeding the rate prescribed in subparagraph (b) of paragraph 2 of Article X (Dividends)." Article X(2)(b) applies withholding tax at the rate of 15 per cent.

${ }^{432}$ Northern Indiana Public Service Company $v$ Commissioner of Internal Revenue 105 TC 341 (1995). Northern Indiana Public Service Company v Commissioner of Internal Revenue 115 F 3d 506 (7th Cir 1997). 
states through Finance, an interposed Dutch company. As with Del Commercial, Northern Indiana guaranteed the repayment of the original loan.

The courts rejected Del Commercial's argument and distinguished the role of the interposed company in the Northern Indiana case from the role of Del Netherlands in the Del Commercial case. The Court of Appeals observed: ${ }^{433}$

In [the Northern Indiana case], ... [t]he appellate court explained that [Finance] participated in the transactions because it could obtain funds on the Eurobond market when "prevailing market conditions made the overall cost of borrowing abroad less than the cost of borrowing domestically.” ... Additionally, [Finance] received a profit from its transactions with the U.S. taxpayer. This profit then was reinvested in the Eurobond market. The "profit motive" of [Finance] was sufficient to show that the motive of the transaction was not simply tax avoidance.

Not only are the two cases not factually similar, but the taxpayer's evidence in [the Northern Indiana case] was substantially stronger than [Del Commercial's] evidence in this case.

It, therefore, could be inferred that the only fact on which the courts in Del Commercial distinguished Finance's function from Del Netherlands' role was the presence of a profit spread.

As discussed in section 4.27, the presence of a profit spread does not sufficiently indicate that an interposed company does not act as a conduit. The courts' agreement with the legal analysis of the Northern Indiana case is relevant because it shows that they considered the presence of a close correspondence between terms of the contracts in Del Commercial as sufficient to indicate that Del Netherlands acted as a conduit. Consequently, they analysed the facts from a formal legalist perspective. Section 6.17 illustrates this point further.

433 Del Commercial Properties Inc $v$ Commissioner of Internal Revenue 251 F 3d 210 (2001) at 216. 


\subsection{Del Commercial: the step transaction doctrine}

Both courts applied the step transaction doctrine. The Court of Appeals explained: "if the sole purpose of a transaction with a foreign corporation is to dodge U.S. taxes, the treaty cannot shield the taxpayer from the fatality of the step-transaction doctrine. ${ }^{\text {434 }}$ It also observed: "In step-transaction cases, the existence of formal business activity is a given but the inquiry turns on the existence of a nontax business motive." ${ }^{435}$

In order to determine the non-tax business motive, both courts investigated whether a "link"436 or "nexus"437 existed between the loan made by the Royal Bank of Canada to Delcom Financial and the loan from Del Netherlands to Del Commercial. The Court of Appeals observed: ${ }^{438}$

[S]everal facts demonstrate the nexus between the original Royal Bank loan and the loan from [Del Netherlands] to [Del Commercial]: (1) the interest rates and repayment schedules of the two loans closely correspond; (2) Royal Bank obtained a guaranty of repayment from [Del Commercial] and a security interest in [Del Commercial's] real property; and (3) ... [Del Commercial] made payments on the loan directly to Delcom Financial ...

The courts emphasised the interdependence of the two loan transactions. That is, they applied the mutualinterdependence test. They did not apply the end-result test because they focused on the parties' intention to avoid tax, not on the parties' intention to reach a particular result.

${ }^{434}$ Del Commercial Properties Inc v Commissioner of Internal Revenue, above n 433, at 214.

${ }^{435}$ Ibid.

${ }^{436}$ Del Commercial Properties Inc $v$ Commissioner of Internal Revenue TC Memo 411 (1999).

437 Del Commercial Properties Inc $v$ Commissioner of Internal Revenue, above n 433, at 214.

${ }^{438}$ Ibid. 
Because the courts found that the two loan transactions were mutually interdependent, they invoked the step transaction doctrine and held that in substance the interest payments by Del Commercial were made to Delcom Financial. For this reason, the Tax Court regarded Del Netherlands as a "mere shell or conduit" $" 439$ and refused a withholding tax exemption under the United StatesNetherlands double tax treaty. It held that Del Commercial was liable for 15 per cent withholding tax on the interest payments under the United States-Canada double tax treaty. The Court of Appeals confirmed the findings of the Tax Court. ${ }^{440}$

\subsection{Del Commercial: the step transaction doctrine and beneficial ownership}

Although Article VI of the United States-Netherlands double tax treaty did not use the term "beneficial owner", 441 the courts implicitly read the beneficial ownership requirement into the provision. The Tax Court observed: ${ }^{442}$

[U]nder [the] treaty between the United States and Canada .... interest payments made by U.S. taxpayers to Canadian corporations are subject to tax at a rate not exceeding 15 percent if the Canadian corporations are the beneficial recipients and owners of the interest income.

The Court of Appeals was of the same opinion. ${ }^{443}$ The courts decided to impose a 15 per cent withholding tax in

439 Del Commercial Properties Inc $v$ Commissioner of Internal Revenue, above n 436.

440 Del Commercial Properties Inc $v$ Commissioner of Internal Revenue, above n 433, at 217.

${ }^{441}$ The United States-Netherlands double tax treaty, above n 430, art VI.

442 Del Commercial Properties Inc $v$ Commissioner of Internal Revenue, above n 436.

443 Del Commercial Properties Inc $v$ Commissioner of Internal Revenue, above n 433, at 213. 
accordance with the United States-Canada treaty, because they considered Delcom Financial to be the beneficial owner of the interest payments. They found that Del Netherlands was a "mere shell or conduit" beneficial owner, Delcom Financial. In other words, they found that Del Netherlands was not the beneficial owner. Their approach implies that they considered the presence of a link between transactions to indicate the absence of beneficial ownership. While this implication is prima facie true, more could be read into the reasoning.

The presence or absence of a link cannot be logically connected to the presence or absence of beneficial ownership. As indicated earlier, the step transaction doctrine is an anti-avoidance doctrine. The existence of a link between transactions indicates the presence of tax avoidance. In Del Commercial, the presence of the link showed that the interposition of Del Netherlands resulted in the use of the United States-Netherlands double tax treaty by Delcom Financial, a Canadian resident, to avoid the United States withholding tax. When the courts found that treaty benefits were in substance being obtained by a resident of a non-contracting state, they regarded Del Netherlands as a conduit, or they did not consider Del Netherlands to be the beneficial owner. Therefore, effectively, the courts did not consider Del Netherlands as a beneficial owner because its interposition resulted in avoidance of the United States withholding tax by a resident of a third state. The courts treated beneficial ownership as an anti-avoidance test, rather than a test of ownership.

${ }^{444}$ Del Commercial Properties Inc $v$ Commissioner of Internal Revenue, above n 436. 
The courts regarded beneficial ownership as a requirement that was informed by the purpose of the limitation of treaty benefits. They did not accord a linguistic interpretation to beneficial ownership. Probably for this reason, they did not adopt a surrogate form of reasoning, whereby they would have considered the presence of a criterion to indicate the presence of beneficial ownership.

As indicated in section 6.4, the Dutch courts have adopted an approach similar to the United States step transaction doctrine. In the $W$-family 1 case, ${ }^{445}$ the Dutch courts determined whether an interposed company was the beneficial owner on the basis of the question of whether the individual steps of a series of transactions were linked. As with the United States courts, the Dutch courts regarded the beneficial ownership test as an antiavoidance test. In order to determine whether the transactions were linked, they investigated whether the parties entered into the transactions with an intention to achieve an end result.

\subsection{The $W$-family 1 case}

The $W$-family 1 case involved Mrs. W, a resident of Belgium, who held shares in a Dutch company, Dutch BV, jointly with family relatives, Ms. D, a Swiss resident, and Mr. S, a resident of the Netherlands. On 20 April 1978, Mrs. W incorporated a wholly owned company in the Netherlands Antilles, Antillean NV. On 30 June 1978, Mrs. W and Ms. D transferred their shares in Dutch BV. While Mrs. W transferred the shares to Antillean NV as a capital contribution, Ms. D sold her shares for a debt that was not yet due. On the same day, the shareholders of Dutch BV

445 W-family 1 (18 May 1994) Case no 28 293, BNB 1994/252 (the Hoge Raad, the Netherlands). 
decided to redeem 10 of the shares that Mrs. W and Ms. D transferred to Antillean NV. Dutch BV redeemed its shares on 20 July 1978.

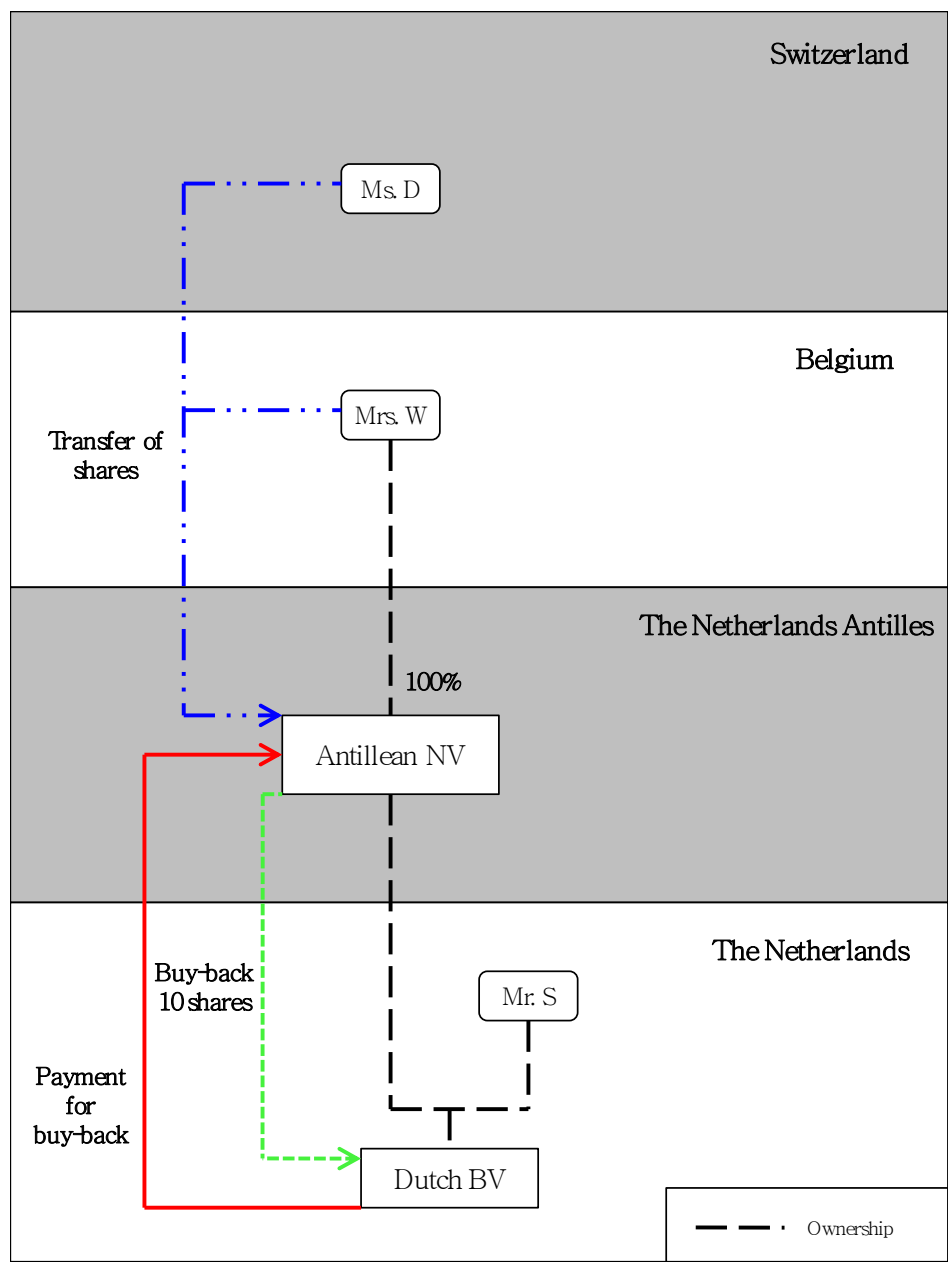

Figure 6.2: The $W$-family 1 case

The Dutch tax inspector characterised the redemption of shares as a repurchase directly from Mrs. W and Ms. D. Treating the payment from Dutch BV as a dividend distribution, he imposed a deficiency assessment for dividend withholding tax. Antillean NV argued that prevailing circumstances prevented family members from managing the business carried out by Dutch BV. It argued, therefore, that Antillean NV was created for the purpose of the concentration of the family's wealth. In the support of this argument, Antillean NV pointed out that, apart from Dutch BV's shares, Mrs. W and Ms. D transferred their 
shareholdings in other Dutch companies to Antillean NV, and that Antillean NV had not distributed any dividends to them. In essence, Antillean NV argued that it was created for valid reasons other than tax avoidance, and was, therefore, entitled to a Dutch withholding tax refund under Article 11 of the BRK. ${ }^{446}$

The lower court of Arnhem confirmed the tax inspector's decision. The Hoge Raad agreed with the lower court.

\subsection{W-family 1: the step transaction doctrine}

The lower court examined the minutes of the meeting of Dutch BV's shareholders and found that they did not simply show that the shareholders of Dutch BV decided to buy back its shares; rather, they showed that the shareholders had also discussed the transfer of shares from Mrs. W and Ms. D to Antillean NV, and comprehensively formulated conditions of the buyback agreement, such as price, guarantee and payments. ${ }^{447}$ Further, the court pointed out that conditions of the deed of transfer between Mrs. W and Ms. D and Antilles NV were included verbatim in the deed of purchase between Antillean NV and Dutch BV. ${ }^{448}$ The court, therefore, concluded (author's translation): ${ }^{449}$

Given the contents of the relevant instruments and the interdependence between them ..., it is obvious that

${ }^{446}$ Tax Arrangement for the Kingdom of the Netherlands (28 October 1964, entered into force 12 December 1985), art 11(3). It provides: "The [dividend withholding tax] ... shall not be levied, or if so levied, shall be refunded with respect to dividends derived by an entity whose capital is wholly or partly divided into shares and which is a resident of the other country and holds at least 25 per cent of the paid-up capital of the company."

447 See "HOF Arnhem 28 juni 1991 (Nr. 1658/1988)" in W-family 1, above $\mathrm{n} 445$, at para 4.4 (emphasis added).

448 Ibid, 4.5 .

${ }^{449}$ Ibid. 
there was a direct interlink between a number of legal acts, the execution of which was decided upon by all those involved before (throughout) 30 June 1978.

The court seems to have examined the events in order to determine whether the acquisition of Dutch BV's shares by Antillean NV and the redemption of the shares by Dutch BV were substantively linked. That is, the court attempted to determine whether the individual transactions should be treated as parts of a single transaction for tax purposes.

The court seems to emphasise that every step was predetermined. ${ }^{450}$ That is, when Mrs. W and Ms. D transferred their shares to Antillean NV, the parties intended that Dutch BV would redeem its shares. The court considered the two transactions to be interlinked because they were intended to achieve the end result that they in fact achieved. In his case note on $W$-family 2, P.J. Wattel expressed the same opinion. Citing IJzerman, ${ }^{451}$ he stated (author's translation): ${ }^{452}$

In my opinion, grounds for the decision indicate a fiscal qualification of the series of transactions as a whole to the end result (purchase). IJzerman describes this way of interpreting the rules of law as follows: "the way chosen is (...) fiscally not qualified in accordance with the separate steps under civil law, but goes directly to the end result with due observance of connections between the agreements". ${ }^{453}$

It is clear that the approach that the lower court of Arnhem adopted corresponds to the end result test as used by the United States court to implement the step transaction doctrine.

\footnotetext{
${ }^{450}$ Also see "Noot" in $W$-family 2 (18 May 1994) Case no 28 296, BNB 1994/253 at para 7 (the Hoge Raad, the Netherlands).

451 RLH IJzerman Het leerstuk van de wetsontduiking in het belastingrecht (Kluwer, Deventer, 1991).

452 "Noot" in $W$-family 2, above n 450, at para 4.

${ }^{453}$ IJzerman, above n 451, at 70.
} 


\subsection{W-family1: link between transactions and tax avoidance}

The court rejected Antillean NV's argument that it was established for the purpose of the concentration of the family's wealth. It observed (author's translation): ${ }^{454}$

Reasons for establishing [Antillean NV] put forward by Dutch BV failed to explain why [Antillean NV] redeemed its shares indirectly through Antillean NV instead of buying them directly from [Mrs. W and Ms. D]. It, therefore, must be assumed that the parties interposed Antillean NV to achieve the redemption of the shares, whereby they used the company solely for tax reasons.

As the Hoge Raad held in ... [Y-group 1990], it is against the purpose of Article 11 BRK to allow treaty benefits in a case where a non-resident of the Netherlands Antilles enjoys dividends distributed by a Dutch company to an Antillean company that is interposed solely to avoid tax. The fact that [Antillean $\mathrm{NV}$ ] has not paid a dividend is insignificant. The interest of the former shareholders in [Dutch BV's] assets is in substance convertible into their interest in [Antillean NV's] assets and therefore is at their disposal.

Essentially the lower court considered the presence of the link between transactions to show that the end result, which was the redemption of the shares by Dutch BV directly from the Mrs. W and Ms. D, caused the use of Article 11(3) of the BRK by residents of non-contracting states to avoid Dutch withholding tax. That is, it regarded the presence of the link between transactions to indicate tax avoidance. The observation confirms that the lower court adopted an approach that was effectively the same as the United States step-transaction doctrine.

\subsection{W-family 1: the step transaction doctrine and beneficial ownership}

Based on its finding that the individual transactions were interlinked, the lower court inferred (author's translation): ${ }^{455}$

\footnotetext{
${ }^{454}$ See "HOF Arnhem 28 juni 1991 (Nr. 1658/1988)" in W-family 1, above n 505, at para 4.7 .
} 
... at least in the period from 30 June 1978 to 20 July 1978, neither had [Antillean NV] any intention of being the economic owner of the shares of Dutch BV, nor had [Mrs. W and Ms. D] envisaged that it would be.

The Hoge Raad drew this same inference. ${ }^{456}$ The courts used the term "economic owner" interchangeably with the term "beneficial owner". ${ }^{457}$ Although Article 11 of the BRK did not use the term "beneficial owner", 458 the courts read the beneficial ownership requirement into the provision. The observation shows that the court did not consider Antillean NV to be the beneficial owner because Mrs. W and Ms. D transferred the shares with the intention that Dutch BV would redeem them. That is, the court did not consider Antillean NV to be the beneficial owner because the transactions were intended to achieve the end result.

As indicated earlier, the courts applied the end result test in order to determine whether the individual transactions should be treated as parts of a single transaction for tax purposes. By implication, because the Dutch courts applied the step transaction doctrine, they concluded that Antillean NV was not the beneficial owner. It could, therefore, be inferred that, as with the United States courts in Del Commercial, the Dutch courts used beneficial ownership as an anti-avoidance test, not a test of ownership.

${ }^{455}$ See "HOF Arnhem 28 juni 1991 (Nr. 1658/1988)" in W-family 1, above $\mathrm{n} 445$, at para 4.6 (emphasis added).

${ }^{456}$ See "[Tekst] ARREST" in $W$-family 1 , above $\mathrm{n} 445$, at para 3.2.1.

${ }^{457}$ See See "[Mening] Conclusie Advocaat-Generaal mr. Verburg" in $W$-family 1 , above $\mathrm{n} 445$, at para 9 .

${ }^{458}$ Tax Arrangement for the Kingdom of the Netherlands, above $\mathrm{n}$ 446, art 11(3). It stated: "The [dividend withholding tax] ... shall not be levied, or if so levied, shall be refunded with respect to dividends derived by an entity whose capital is wholly or partly divided into shares and which is a resident of the other country and holds at least 25 per cent of the paid-up capital of the company." 


\subsection{Link between transactions: an indecisive approach}

The courts of the United States and the Netherlands adopted similar approaches in conduit company cases that concerned the same issues. Because they found that individual transactions were linked, they considered the immediate recipients acted as conduits and therefore were not entitled to treaty benefits. They considered the presence of a link to be an indicator of the absence of beneficial ownership.

In Del Commercial and $W$-family 1 , the arrangement involved the interposition of an immediate recipient for the purpose of obtaining a withholding tax reduction under the relevant double tax treaties. The parties implemented the arrangement with the help of transactions by which ownership of income generating assets were transferred from the resident state to the source state. That is, the transactions were the overt acts. It follows that the courts examined the overt acts when they investigated the series for determining whether the individual steps were interlinked. To this extent, the application of the step transaction doctrine corresponds to the "reasons for the existence" approach as discussed in chapter 3. However, as sections 6.15 and 6.28 illustrate, unlike the "reasons for existence" approach, the courts did not consider the arrangement as a whole. They focused only on transactions where the parties transfer passive income generating assets from a resident state to a source state.

In Del Commercial and $W$-family 1 , the courts began by adopting the correct approach; however, they constricted the approach because they based their decisions on transactions concerning the transfer of assets from the resident company to the source company. The presence of a link may show that an immediate recipient acts as a 
conduit; however, its absence does not necessarily show that an immediate recipient does not act as a conduit. The following sections analyse the reasoning of the courts in Del Commercial and $W$-family 1 further.

\subsection{Del Commercial: did courts consider the arrangement as a whole?}

In Del Commercial Properties Inc $v$ Commissioner of Internal Revenue, ${ }^{459}$ the United States courts were of the opinion that the loan made by the Royal Bank of Canada to Delcom Financial was substantially linked to the loan from Del Netherlands to Del Commercial. As indicated in section 6.8, the United States Court of Appeals for the District of Columbia Circuit considered three facts. ${ }^{460}$ First, there was a close correspondence in interest rates and repayment schedules of the two contracts. Second, Del Commercial provided a guarantee and security over its property to the bank for the loan that it borrowed from Del Netherlands. Third, Del Commercial repaid the loan directly to Delcom Financial.

The court seems to have examined the arrangement as a whole. However, the distinction that the court drew between the function of Finance in Northern Indiana on one hand and the role of Del Netherlands on the other shows that it based its decision on the co-relation of interest rates and payment schedules. The distinction was based on the fact that Finance in Northern Indiana earned a profit spread on the inflow and outflow of interest.

Considering the frame of reference within which the court in Del Commercial analysed the facts for applying

\footnotetext{
459 Del Commercial Properties Inc v Commissioner of Internal Revenue TC Memo 411 (1999). Del Commercial Properties Inc v Commissioner of Internal Revenue 251 F 3d 210 (2001).

460 Del Commercial Properties Inc $v$ Commissioner of Internal Revenue 251 F 3d 210 (2001) at 216.
} 
the mutual-interdependence test, it viewed the presence of a profit spread to show that the interest rates with respect to individual loan transactions were different. This difference indicated that the transactions were independent. For this reason, the court in Del Commercial did not regard Finance as a conduit.

In Del Commercial, the United States Court of Appeals for the District of Columbia Circuit observed: "In steptransaction cases, the existence of formal business activity is a given but the inquiry turns on the existence of a nontax business motive." ${ }^{\text {461 }}$ Applying the step transaction doctrine, it assumed that Del Netherlands carried out a substantive business activity, even though the United States Tax Court found otherwise. ${ }^{462}$ The approach shows that the court did not examine the arrangement as a whole. It regarded the similarity between the two loan contracts as sufficient to indicate that Del Netherlands acted as a conduit. This point can be explained further by comparing the approach of the court in Del Commercial with that of the England and Wales Court of Appeal in Indofood International Finance Ltd v JP Morgan Chase Bank NA, London Branch. ${ }^{463}$

\subsection{The Indofood case}

As discussed in section 5.9, the Indofood case ${ }^{464}$ involved an Indonesian company, Indofood, which incorporated a Mauritian subsidiary, Finance, to borrow funds from international investors. Indofood established the structure

461 Del Commercial Properties Inc $v$ Commissioner of Internal Revenue, above n 460, at 214.

462 Del Commercial Properties Inc $v$ Commissioner of Internal Revenue TC Memo 411 (1999).

${ }^{463}$ Indofood International Finance Ltd v JP Morgan Chase Bank NA, London Branch [2006] EWCA Civ 158.

${ }^{464}$ Ibid. 
in order to obtain an Indonesian withholding tax reduction under the Indonesia-Mauritius double tax treaty of 10 December $1996 .{ }^{465}$

Before the bonds matured, the government of Indonesia issued a notice terminating the treaty, which led to a dispute between Indofood and the paying agent of the bondholders, JP Morgan. While Indofood wished to redeem the bonds at par, which was a possible option under the contract, JP Morgan contended that Indofood could establish another subsidiary in the Netherlands, Dutch BV and could assign to Dutch BV the ownership of its debt to Finance.

In order to decide whether establishing Dutch BV was a reasonable measure, the England and Wales Court of Appeal had to determine whether Dutch BV would be considered to be the beneficial owner of interest payments from Indofood under the Indonesia-Netherlands double tax treaty of 29 January $2002 .{ }^{466}$ The court found that Finance did not own the interest payments beneficially. Since Dutch BV was most likely to take over Finance's obligations, the court held that Dutch BV would not be considered the beneficial owner. ${ }^{467}$

The court examined the "legal, commercial and practical structure behind the loan notes". ${ }^{468}$ In considering the legal structure, it noted the fact that

${ }^{465}$ Convention for Avoidance of Double Taxation and the Prevention of Fiscal Evasion with Respect to Taxes on Income, IndonesiaMauritius (10 December 1996, entered into force 12 January 1998), art 10(2)

${ }^{466}$ Convention for Avoidance of Double Taxation and the Prevention of Fiscal Evasion with Respect to Taxes on Income, the NetherlandsIndonesia (29 January 2002, entered into force 1 January 2004), art 10(2).

${ }^{467}$ Indofood International Finance Ltd v JP Morgan Chase Bank NA, London Branch, above n 463, at para 43.

468 Ibid. 
Finance was, and Dutch BV would be, contractually bound to pay to JP Morgan what it received from Indofood. Although the same inflow and outflow of interest also indicated that Finance acted, and Dutch BV would act, as a conduit, the court did not regard this fact as decisive. The court maintained that basing the decision on this fact meant assigning a narrow and technical meaning to the term "beneficial owner", ${ }^{469}$ The court accorded equal importance to the facts that Finance had borrowed funds from the bondholders against Indofood's guarantee and that after paying the first instalment of interest to Finance, Indofood had paid interest directly to JP Morgan. ${ }^{470}$ According to the court, these facts show that, in commercial and practical terms, Finance or Dutch BV could not derive any direct benefit from the interest payments from Indofood. The point is that the court considered the arrangement as a whole.

Comparing Del Commercial with the Indofood case, it is clear that, as with the Indofood case, Del Commercial involved a back-to-back loan structure. The observation quoted in section 6.8 shows that the facts that the United States court noted are similar to those that the England and Wales Court of Appeal considered in Indofood. However, unlike the court in the Indofood, the court in Del Commercial did not accord equal significance to each fact. Although the United States court noted the facts, it based its decision on the close correspondence between the loan contracts, which also showed the same inflow and outflow of interest. That is, the United States court did not consider the arrangement as a whole. In the light of the approach

\footnotetext{
${ }^{469}$ Indofood International Finance Ltd v JP Morgan Chase Bank NA, London Branch, above n 463, at para 44.

${ }^{470}$ Ibid.
} 
adopted by the court in Indofood, it could be inferred that, although the courts in Del Commercial used the beneficial ownership test as an anti-avoidance test, they narrowed down the scope of the test. Consequently, they ended up assigning it a technical interpretation.

\subsection{Del Commercial: narrow and technical approach}

Similar terms and conditions of contracts may show that transactions are interlinked, and therefore, the interposed company acts as a conduit; however, logically an intermediary company can still act as a conduit even if terms and conditions of contracts differ. The approach may imply that a difference between terms and conditions of contracts shows that an immediate recipient is the beneficial owner of passive income even if it does not carry out a substantive business activity. Another United States case, SDI Netherlands BV $v$ Commissioner of Internal Revenue, ${ }^{471}$ helps to illustrate the argument.

The SDI Netherlands case ${ }^{472}$ turned on the issue of the source of royalty payments made by an interposed company to a resident company that was a resident of a third state. The court applied the source rule under section 861(a)(4) of the United States Internal Revenue Code, ${ }^{473}$ which makes the source of royalty payments the country in which the licensed intangible property is used.

${ }^{471}$ SDI Netherlands BV v Commissioner of Internal Revenue $107 \mathrm{TC}$ 161 (1996).

472 Ibid

${ }^{473}$ Internal Revenue Code 26 USC $\S 861(a)(4)$. It provides: (a) The following items of gross income shall be treated as income from sources within the United States:

(4) Rentals or royalties from property located in the United States or from any interest in such property, including rentals or royalties for the use of or for the privilege of using in the United States patents, copyrights, secret processes and formulas, good will, trade-marks, trade brands, franchises, and other like property. 
The United States Tax Court in SDI Netherlands did not consider payments from the immediate recipient to the company in the resident state to constitute United States sourced income. It considered that regarding the royalty payments by the immediate recipient as United States sourced income could cause a cascading royalty problem, whereby multiple withholding taxes could be paid on the same royalty payment as it is moved up a chain of licensors. $^{474}$

This chapter refers to the SDI Netherlands case in a different context. It does not concern the source rule per se. It concerns the reasoning that the court adopted when applying the rule. The court had to decide whether royalties that the interposed company passed on to the resident of a third state constituted income received from a source within the United States. It effectively determined whether licensing agreements through which parties transferred the intellectual property from the third state to the source state via an intermediary state were connected. The court regarded the agreements as separate because their terms were different.

\subsection{The SDI Netherlands case}

SDI Netherlands involved the SDI group, which was engaged in the software business. SDI Ltd, a Bermudan parent company wholly owned SDI Bermuda, another Bermudan company. SDI Ltd also held all the shares in SDI Antilles, a company incorporated in the Netherlands Antilles. SDI Antilles in turn wholly owned SDI Netherlands, a Dutch company, which was also the taxpayer. SDI Netherlands held all the shares in SDI USA, a company resident in the United States. In addition to SDI

${ }^{474}$ SDI Netherlands BV v Commissioner of Internal Revenue, above $\mathrm{n}$ 471 , at 176 . 
USA, SDI Netherlands wholly owned subsidiaries in Germany, France and the United Kingdom.

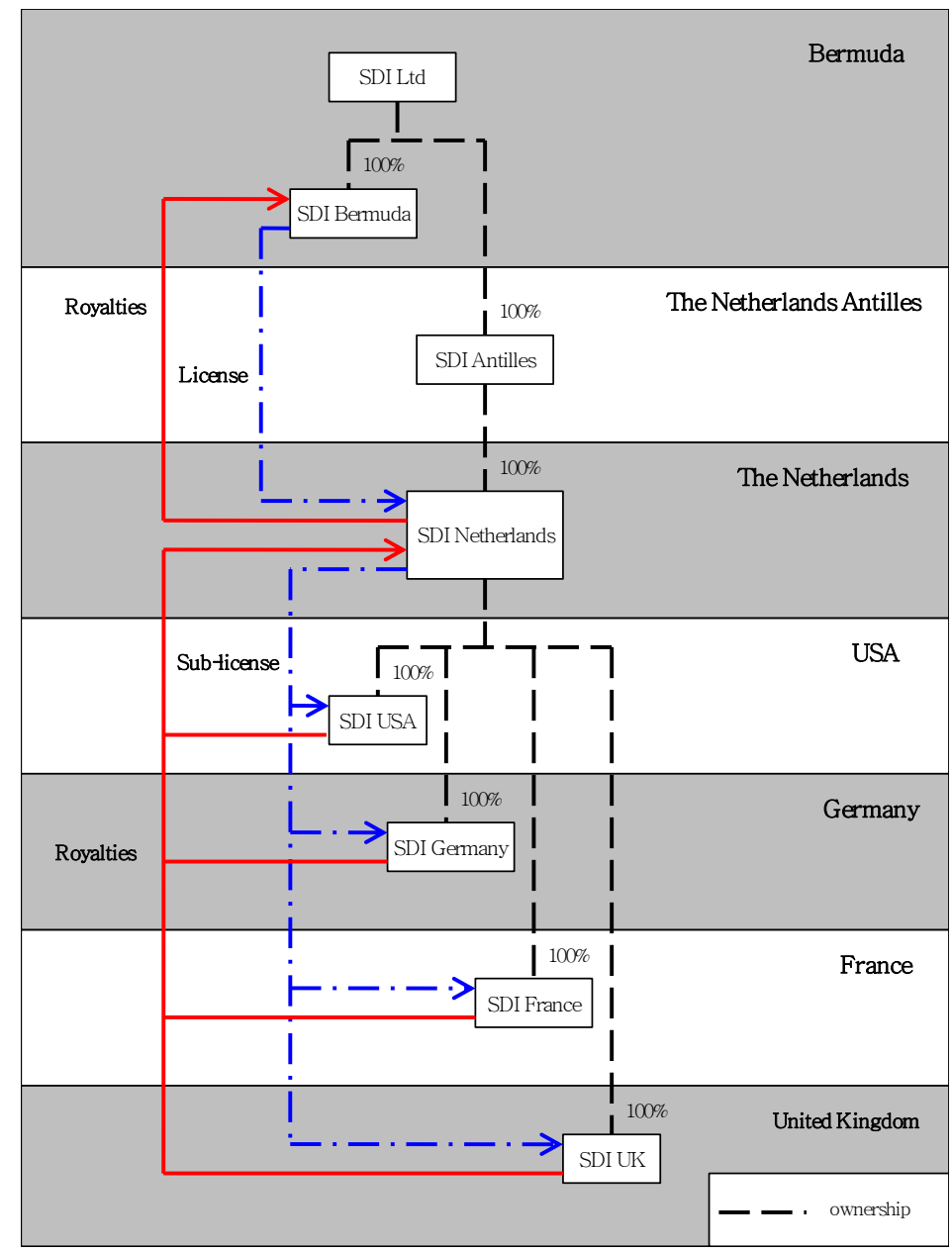

Figure 6.3: The SDI Netherlands case

The United States Tax Court noted: “SDI Ltd. provided management services to certain of its direct and indirect subsidiaries for which such subsidiaries paid it management fees". ${ }^{475}$ In the light of the structure of the SDI group, it could be assumed that SDI Ltd provided management services to at least some of the subsidiaries of SDI Netherlands.

In a license agreement, SDI Bermuda granted SDI Netherlands rights to use or to market its software on a worldwide basis. Subsequently, SDI Netherlands entered

${ }^{475}$ SDI Netherlands BV $v$ Commissioner of Internal Revenue, above $\mathrm{n}$ 471, at 176 . 
into a sub-license agreement with SDI USA, whereby it granted SDI USA the rights to use or market the software only within the United States. SDI Netherlands apparently also entered into sub-license agreements with its other subsidiaries. Terms and conditions of the head-and-subagreements differed particularly with respect to the rate of royalties. Consequently, SDI Netherlands earned a profit spread on the inflow and outflow of royalties.

Royalty payments from the United States companies to Dutch companies were exempt from United States withholding tax under Article IX of the United StatesNetherlands double tax treaty of 29 April $1948 .{ }^{476}$ During the years in question, SDI USA and SDI Netherlands made royalty payments in accordance with their respective agreements without deducting the United States withholding tax. The Commissioner of Internal Revenue issued notices of deficiency against SDI Netherlands.

\subsection{The "flow-through characterisation concept"}

The Commissioner argued that the royalty payments from SDI Netherlands to SDI Bermuda constituted United States source income under section 861(a)(4) of the $\operatorname{IRC}^{477}$ because they were paid for the use of the software in the United States. The Commissioner relied on the Revenue Ruling $80-362,{ }^{478}$ which also concerned Article IX of the United States-Netherlands double tax treaty. ${ }^{479}$

\footnotetext{
476 Supplementary Convention Modifying and Supplementing the Convention with Respect to Taxes on Income and Certain other Taxes (30 December 1965, entered into force 8 July 1966), art IX(1). Article IX(1) stated: "Royalties paid to a resident or corporation of one of the Contracting States shall be exempt from tax by the other Contracting State."

${ }^{477}$ Section 861(1)(4) IRC, above n 473.

${ }^{478}$ Revenue Ruling 80-326 (1980) 2 св 208.

${ }^{479}$ The United States-Netherlands double tax treaty, above n 476.
} 
Revenue-Ruling 80-362 involved A, a resident of a third state, who licensed the rights to a United States patent to $\mathrm{X}$, an unrelated Dutch corporation. $\mathrm{X}$ agreed to pay a fixed royalty each year to A. X relicensed the United States patent rights to Y, a United States company. The ruling found royalties from $\mathrm{Y}$ to $\mathrm{X}$ exempt under Article IX(1) of the United States-Netherlands treaty. However, it determined that because no tax convention existed between A's country of residence and the United States providing a similar exemption and because: ${ }^{480}$

the royalties from $\mathrm{X}$ to $\mathrm{A}$ are paid in consideration for the privilege of using a patent in the United states, they are treated as income from source within the United States under section 861(a)(4) and are subject to United States income taxation ...

In SDI Netherlands, the Commissioner viewed the case as a simple matter of tracing the percentage of royalty payments from SDI Netherlands to SDI Bermuda back to the royalty paid by SDI USA to SDI Netherlands and treating that percentage of payment as United States source income. ${ }^{481}$ The case turned on the issue of whether the royalties paid by SDI Netherlands to SDI Bermuda constituted income received from a source within the United States and therefore were subjected to withholding $\operatorname{tax}^{482}$

The court referred to the Commissioner's argument as the "flow-through characterisation concept". ${ }^{483}$ Rejecting the argument, it held that the two license agreements: ${ }^{484}$

\footnotetext{
${ }^{480}$ Revenue Ruling 80-326, above n 478 (emphasis added).

${ }^{481}$ SDI Netherlands BV v Commissioner of Internal Revenue 107 TC 161 (1996), at 172

${ }^{482}$ Ibid, at 171.

${ }^{483}$ Ibid, at 174.

${ }^{484}$ Ibid, at 175.
} 
should be accorded separate status with the result that, although the royalties paid by [SDI Netherlands] to SDI Bermuda were derived from the royalties received by [SDI Netherlands] from SDI USA, they were separate payments.

\subsection{The "flow-through characterisation concept" and link between transactions}

Although SDI Netherlands did not concern the step transaction doctrine, the logic of the "flow-through characterisation concept" corresponds to the logic of the step transaction doctrine.

As with Del Commercial ${ }^{485}$ and $W$-family $1,{ }^{486}$ SDI Netherlands involved back-to-back transactions whereby parties transferred an income-generating asset from a resident state to a source state. That is, instead of licensing the software directly to SDI USA, SDI Bermuda first granted a license to SDI Netherlands, which in turn licensed it to SDI USA. It is obvious from the Revenue-Ruling 80-326 that the "flow-through" concept traces passive income in the hands of an ultimate recipient back to its source on the basis that income payment made by an immediate recipient to the ultimate recipient was "in consideration" 487 of the right to use income-generating assets. The term "in consideration" connotes a connection or a link between the payment and the income-generating assets located in the source state.

The court in SDI Netherlands ${ }^{488}$ investigated whether royalty payments from SDI Netherlands to SDI Bermuda were linked to royalty payments from SDI USA to SDI

\footnotetext{
485 Del Commercial Properties Inc $v$ Commissioner of Internal Revenue TC Memo 411 (1999). Del Commercial Properties Inc v Commissioner of Internal Revenue 251 F 3d 210 (2001).

486 W-family 1 (18 May 1994) Case no 28 293, BNB 1994/252 (the Hoge Raad, the Netherlands).

${ }^{487}$ Revenue Ruling 80-326, above n 478.

${ }^{488}$ SDI Netherlands BV $v$ Commissioner of Internal Revenue, above $\mathrm{n}$ 481 , at 175 .
} 
Netherlands. In order to determine the issue it examined terms and conditions of the license agreements with respect to each transaction. Its approach corresponds to that adopted by the courts in Del Commercial. It is instructive to analyse the reasoning of the court in SDI Netherlands.

\subsection{The "flow-through concept" and the "conduit concept": an analogy}

The court noted that Commissioner did not argue that: ${ }^{489}$

[SDI Netherlands] was a mere conduit or agent of SDI USA in paying royalties to SDI Bermuda or that SDI Bermuda was the beneficial owner of the royalties [SDI Netherlands] received from SDI USA so that the USNetherlands exemption should not apply.

Nevertheless, it relied on Aiken Industries Inc $v$ Commissioner of Internal Revenue 490 and Northern Indiana Public Service Company $v$ Commissioner of Internal Revenue, ${ }^{491}$ which were decided on the issue of whether the immediate recipient of passive income acted as a conduit. When justifying its approach, the court observed: ${ }^{492}$

Although [Aiken Industries] ... and [Northern Indiana] ... involved the conduit concept, we think they provide some guidance for our disposition of the instant case. We take this view because the flow-through [characterisation] concept is, in a very real sense, the conduit concept albeit in a somewhat different garb, i.e., whether the U.S. source income is being received as such, because of the status of the paying entity in one case, and the status of the subject matter of the payment in the other.

${ }^{489}$ SDI Netherlands BV v Commissioner of Internal Revenue, above $\mathrm{n}$ 481, at 173 .

${ }^{490}$ Aiken Industries Inc v Commissioner of Internal Revenue $56 \mathrm{TC}$ 925(1971).

491 Northern Indiana Public Service Company $v$ Commissioner of Internal Revenue 105 TC 341 (1995). Northern Indiana Public Service Company $v$ Commissioner of Internal Revenue 115 F 3d 506 (7th Cir 1997).

${ }^{492}$ SDI Netherlands BV $v$ Commissioner of Internal Revenue, above $\mathrm{n}$ 481, at 174 (emphasis added). 
Although Article IX of the United States-Netherlands double tax treaty did not use the term "beneficial owner", ${ }^{493}$ these observations suggest that, as with the courts in $W$-family 1 and Del Commercial, the court in SDI Netherlands read the beneficial ownership requirement into the provision. It did so by drawing an analogy between the "conduit concept" and the "flow-through characterisation concept". The words "is being received as such",494 and "the subject matter of the payment"495 suggest that the court focused on the form in which income reached the ultimate owner. That is, the court considered each concept to address the issue of whether an ultimate recipient received income as it originated from the source state.

As discussed in section 5.5, because a conduit company may not always act as an agent, it does not necessarily pass on income to a resident of a third state in the original form. The point is that by treating the two concepts as being effectively the same, the court restricted the meaning of a conduit to an agent, or the scope of the beneficial ownership requirement to a person who does not act in the capacity of an agent. As a result, the court referred to Aiken Industries and Northern Indiana in a narrow sense.

\footnotetext{
${ }^{493}$ Supplementary Convention Modifying and Supplementing the Convention with Respect to Taxes on Income and Certain other Taxes (30 December 1965, entered into force 8 July 1966), art IX(1). Article IX(1) stated: "Royalties paid to a resident or corporation of one of the Contracting States shall be exempt from tax by the other Contracting State."

${ }^{494}$ SDI Netherlands BV v Commissioner of Internal Revenue, above $\mathrm{n}$ 481, at 174.

${ }^{495}$ Ibid.
} 


\subsection{The court's interpretation of Aiken Industries and Northern Indiana}

When applying its analysis of Aiken Industries and

Northern Indiana to the present case, the court observed: ${ }^{496}$

... the ... situation falls more within the ambit of Northern Indiana than Aiken Industries. In the latter case, there was an identity both in terms and timing between the back to back loans, as well as a close relationship between the parties involved. In the former case, although there was a clear connecting purpose between the borrowing and lending transactions, i.e., to obtain the benefit of the exemption from the withholding tax on interest under the U.S.-Netherlands treaty; there were differences in terms, i.e., in the interest rate (albeit not large); and a close relationship between all the parties was not present since the borrowings by the finance subsidiary were from unrelated parties.

The observation shows that in order to determine whether SDI Netherlands was a conduit, or whether SDI Netherlands was not the beneficial owner, the court restricted its investigation to two issues.

First, the words "a clear connecting purpose between ... transactions" suggest that the court considered the presence of a connection between transactions to indicate that SDI Bermuda interposed SDI Netherlands as a conduit in order to avoid the United States withholding tax on royalty payments from SDI USA. In order to ascertain whether the transactions were connected, the court focused on whether terms and conditions of contracts were identical. This approach is similar to that of the courts in Del Commercial.

Second, the court examined whether a close relationship existed between an interposed company and the other parties.

${ }^{496}$ Ibid, at 175 (emphasis added). 


\subsection{Similarity in terms and conditions}

When referring to Aiken Industries ${ }^{497}$ and Northern Indiana $^{498}$ in the context of the flow-through argument, the court focused on the similarities of terms and conditions. It approved the reasoning in Northern Indiana. It held that Finance was not considered to be a "mere conduit or agent" because it earned a profit spread on the inflow and outflow of the interest. ${ }^{499}$

From the observation quoted in section 6.22 , it is clear that the court regarded the presence of the profit spread in Northern Indiana to show that the terms and conditions of the contracts differed. In the light of the analogy that the court drew between the flow-through concept and the conduit concept, ${ }^{500}$ its reasoning implied that a difference between terms and conditions of contracts with respect to individual transactions indicates that an interposed company is entitled to treaty benefits. The court in Del Commercial $^{501}$ seemed to adopt the same approach.

In the SDI Netherlands case, when determining whether such a similarity existed, the court observed: ${ }^{502}$

The facts of the matter are that the two license agreements had separate and distinct terms and that [SDI Netherlands] had an independent role as the licensee from SDI Bermuda and the licensor of the other entities, including but not limited to SDI USA. The schedules of royalty payments [provide] for a spread, not unlike the

${ }^{497}$ Aiken Industries Inc $v$ Commissioner of Internal Revenue, above $\mathrm{n}$ 490.

498 Northern Indiana Public Service Company $v$ Commissioner of Internal Revenue 105 TC 341 (1995). Northern Indiana Public Service Company v Commissioner of Internal Revenue 115 F 3d 506 (7th Cir 1997).

499 SDI Netherlands BV v Commissioner of Internal Revenue 107 TC 161 (1996), at 174.

${ }^{500}$ Ibid, at 174 .

501 Del Commercial Properties Inc $v$ Commissioner of Internal Revenue 251 F 3d 210 (2001) at 216.

${ }^{502}$ SDI Netherlands BV $v$ Commissioner of Internal Revenue, above $\mathrm{n}$ 499, at 175 . 
spread involved in Northern Indiana, which compensated [SDI Netherlands] for its efforts. Like the finance subsidiary in Northern Indiana, [SDI Netherlands] engaged in licensing activities from which it realized substantial earnings. In fact, on a percentage basis, it earned between 5 and 6 percent, compared to the 1 percent earned by [the] finance subsidiary in Northern Indiana. Under the circumstances herein, we think these arrangements should be accorded separate status with the result that, although the royalties paid by [SDI Netherlands] to SDI Bermuda were derived from the royalties received by [SDI Netherlands] from SDI USA, they were separate payments.

It is clear that the court did not regard SDI Netherlands as a conduit because the terms and conditions of the license agreements differed.

As discussed in section 6.20, the "flow-through characterisation concept" corresponds to the logic of the step transaction doctrine. Further, as with the Del Commercial, the court in SDI Netherlands regarded the difference between terms and conditions of contracts to indicate that transactions were not linked. For these reasons, SDI Netherlands could be considered to illustrate that the narrow and technical approach adopted by the court in Del Commercial may imply that a simple difference in terms and conditions of contracts with two individual transactions shows that an intermediary is not a conduit. The fact that the rates of royalty payments differ does not help in deciding whether an interposed company is a conduit. It has no economic significance in the context of a conduit company case because the royalty payments flow to the same destination.

\subsection{Close relationship}

As discussed in section 6.22, the court considered the absence of a close relationship between the parties to indicate that an interposed company does not act as a conduit. However, an interposed company can act legally 
or substantively as a conduit, even if it is unrelated to the other parties. ${ }^{503}$

Further, since the court's analogy between the "flowthrough characterisation concept" and the "conduit concept" restricted the meaning of a conduit to an agent, it could be inferred that the court considered the factor of "close relationship" in a formal legalistic sense. When determining whether such a relationship existed, it observed: ${ }^{504}$

In the instant case, there was a close relationship between the parties. However, although [counsel for the Commissioner] asks us, in passing, to take that relationship into account, she does not pursue the matter to the point where she contends that it is a significant factor. Given the fact that [counsel for the Commissioner] [recognises] the existence of all of the parties as valid corporate entities and does not attack the bona fides of the license agreements between SDI USA and [SDI Netherlands], on the one hand, or [SDI Netherlands] and SDI Bermuda, on the other, we are not disposed to allow the close relationship element to control our decision.

The court's dilemma between the substantive economic perspective and the formal legalistic perspective is apparent. On one hand, the court seems to be of the view that the facts showed that the parties were closely related and the substance of the license agreement was questionable. This view seems to incline towards the substantive economic perspective. On the other hand, since the court decided the case in the context of the "flow-through characterisation concept", it held that there was no close relationship between the parties simply because the Commissioner recognised their existence as

\footnotetext{
${ }^{503}$ For example Ministre de l'Economie, des Finances et de l'Industrie v Société Bank of Scotland (2006) 9 ITLR 683 (Conseil d'etat, France) and Royal Dutch Shell (6 April 1994) Case no 28 638, BNB 1994/217 (the Hoge Raad, the Netherlands).

${ }^{504}$ SDI Netherlands BV v Commissioner of Internal Revenue, above $\mathrm{n}$ 499, at 175.
} 
valid corporate entities. That is, the court allowed itself to be governed by the legal perspective.

\subsection{Reasons for existence of SDI Netherlands}

As discussed in section 6.18, SDI Bermuda granted the rights to market and to use its software on a worldwide basis exclusively to SDI Netherlands. The license agreement between SDI Netherlands and SDI USA granted SDI USA a right to use the software only within the United States. If SDI Bermuda had licensed the software directly to SDI USA, royalty payments from SDI USA would have incurred United States withholding tax at the statutory rate. Locating SDI Netherlands in the Netherlands not only ensured that the royalty payments from SDI USA were exempt from United States withholding tax, but also allowed royalties to flow from the United States to Bermuda without being taxed because the Netherlands does not impose withholding tax on out-flowing royalties.

As indicated in section 6.18, it was SDI Ltd that provided management services to subsidiaries of SDI Netherlands. In the light of this fact, SDI Netherlands' activity appears limited to sub-licensing the software to its subsidiaries. For this reason, it cannot be considered to be engaged in substantive business activity, even if it earned a profit on the inflow and outflow of the royalties. As discussed in section 4.26 , the presence of a profit spread does not necessarily indicate the presence of a substantive business activity.

These facts contribute to the conclusion that SDI Netherlands existed in the SDI group for no other reason than to obtain the exemption of the United States withholding tax under the United States-Netherlands double tax treaty. 


\subsection{W-family 1: deviation from the reasons for existence approach}

As discussed in section 6.11, the lower court of Arnhem in $W$-family $1^{505}$ also used the step transaction doctrine. It applied the end-result test and found that the transactions were interlinked because the parties implemented them with the intention that Dutch BV would redeem the shares. It, therefore, applied the step transaction doctrine and treated the transactions as part of a single transaction, which was a transfer of shares from Mrs. W and Ms. D to Dutch BV. The court concluded that allowing treaty benefits would be contrary to the purpose of the restricting treaty benefits to residents of contracting states because in substance residents of non-contracting states derived treaty benefits. For this reason, the court did not regard Antillean NV as the beneficial owner. That is, it treated Antillean NV as a conduit, and therefore denied the Dutch withholding tax reduction under Article 11(3) of the BRK. ${ }^{506}$ In effect, the court treated the beneficial ownership test as an antiavoidance test.

The lower court referred to the $Y$-group 1990 case, ${ }^{507}$ in which the Hoge Raad adopted the "reasons for existence" approach. As with the lower court, the Hoge Raad also regarded the term beneficial owner as a requirement for limiting treaty benefits and treated beneficial ownership as an anti-avoidance test. The lower court's reference to $Y$ group 1990 creates an impression that it followed the "reasons for existence" approach. While the lower court did begin by asking the same question as that asked by the

505 W-family 1 (18 May 1994) Case no 28 293, BNB 1994/252 (the Hoge Raad, the Netherlands).

506 Tax Arrangement for the Kingdom of the Netherlands (28 October 1964, entered into force 12 December 1985).

507 Y-group 1990 (28 June 1989) Case no 25 451, BNB 1990/45 (the Hoge Raad, the Netherlands). 
Hoge Raad in Y-group 1990, its approach differed considerably. Before comparing the approach of the two courts, it is helpful to recall the Y-group 1990 case.

\subsection{The $Y$-group 1990 case}

As discussed in section 3.5, Y-group 1990 involved Y Canada, a Canadian company, which wholly owned Y Netherlands, a Dutch company. After Y Netherlands declared dividends, Y Canada incorporated Y Antilles, an Antillean company, which it owned jointly with $\mathrm{P}$ Panama, a Panamanian company. Y Netherlands paid a part of its dividends to Y Canada. Subsequently, Y Canada bifurcated shares of $\mathrm{Y}$ Netherlands into ordinary and preference shares, and sold the ordinary shares to $\mathrm{Y}$ Antilles. Y Netherlands paid the remaining amount of the dividend to $\mathrm{Y}$ Antilles after deducting the Dutch withholding tax.

The Dutch tax inspector refused Y Antilles' request for a withholding tax reduction under Article 11 (3) of the BRK. ${ }^{508}$ The tax inspector argued that Y Antilles had no practical significance in the corporate structure.

As indicated in section 3.6, the lower court of Amsterdam and the Hoge Raad read the beneficial ownership requirement into Article 11(3) of the BRK. The Hoge Raad assigned the term "beneficial owner" the function of limiting the benefit of the withholding tax reduction to residents of the contracting states. When

\footnotetext{
${ }^{508}$ Tax Arrangement for the Kingdom of the Netherlands (28 October 1964, entered into force 12 December 1985), art 11(3). It stated: "The [dividend withholding tax] ... shall not be levied, or if so levied, shall be refunded with respect to dividends derived by an entity whose capital is wholly or partly divided into shares and which is a resident of the other country and holds at least 25 per cent of the paid-up capital of the company."
} 
interpreting Article 11(3), it observed (author's translation): 509

... Article 11 is intended to prevent double taxation of dividends payable by a company resident in the Netherlands or the Netherlands Antilles, and enjoyed by a resident of one of these countries.

The lower court of Amsterdam and the Hoge Raad agreed with the tax inspector. Considering the arrangement in its entirety, they could not find any practical significance for the existence of Y Antilles. They treated the arrangement as if $\mathrm{Y}$ Canada had received the dividend and held that granting a withholding tax reduction to Antillean NV would contradict the object and purpose of Article 11(3) of the BRK. ${ }^{510}$

\subsection{W-family 1: did the court consider the arrangement in its entirety?}

The Hoge Raad in Y-group 1990 considered the arrangement as a whole and denied the withholding tax reduction to $\mathrm{Y}$ Antilles because it could not find valid reasons for the existence of $\mathrm{Y}$ Antilles. Relatively, the lower court of Arnhem in $W$-family 1 adopted a narrower approach. The lower court confined itself to the share transactions involving the parties. It based its decision to deny the withholding tax reduction to Antillean NV on the presence of a link between these transactions. It did not consider the arrangement as a whole, which necessitates examining the flow of income from Dutch BV to Mrs. W and Ms. D. The opinion of the Advocate General, Mr.

509 Tax Arrangement for the Kingdom of the Netherlands, above $n$ 508, at para 4.6.

510 "Beoordeling van het middel" in Y-group 1990, above n 507, at para 4.2 . 
Verburg, in $W$-family 1 supports these points. He observed (author's translation): ${ }^{511}$

The court has recognised such a connection between separate successive acts, which led to the redemption of the shares by Antillean NV, that in its opinion no significance should be accorded to the order in which various signatures are placed.

How could the following be inferred:

"at least in the period from 30 June 1978 to 20 July 1978, neither had [Antillean NV] any intention of being the economic owner of the shares of Dutch BV, nor had [Mrs. W and Ms. D] envisaged that it would be."

I assume ... the court meant that Antillean NV and its shareholders had no practical significance.

The court in [Y-group 1990] ... held as follows:

"The interconnecting interested parties with respect to the dispute in question, therefore, lacked a practical reason and the dividend came exclusively from tax considerations."

Such an inference, it seems to me, requires $a$ broader foundation than that applied by the court ...

The observation suggests that the lower court of Arnhem did not take into account the arrangement in its entirety. It also confirms that the Hoge Raad in Y-group 1990 adopted a broader approach than the one adopted by the lower court of Arnhem in $W$-family 1.

As a result of relying solely on the presence of the link, the lower court of Arnhem inadvertently assigned a strict legalistic interpretation to the beneficial ownership requirement. Its reasoning implied that the absence of a link between transactions necessarily means that an interposed company does not act as a conduit. The Hoge Raad drew this implication when it followed the reasoning of the lower court of Arnhem in $W$-family 2. ${ }^{512}$

\subsection{The $W$-family 2 case}

$W$-family 2 involved the same family as $W$-family 1 . On 30 June 1978, Mrs. W and Ms. D transferred their shares in

\footnotetext{
511 "[Mening] Conclusie Advocaat-Generaal mr. Verburg" in Y-group 1990, above $\mathrm{n}$ 507, at para 7 (emphasis added).

${ }^{512}$ W-family 2 (18 May 1994) Case no 28 296, BNB 1994/253 at para 4 (the Hoge Raad, the Netherlands).
} 
other Dutch corporations, in addition to their Dutch BV's shares, to Antillean NV. Netherlands BV was one of the other Dutch corporations. Mrs W and Ms. D each transferred their shares to Antillean NV as a capital contribution and for a profit sharing right. Unlike the position in the $W$-family 1 case, however, Netherlands BV did not redeem its shares from Antillean NV. Rather, Netherlands BV distributed dividends to Antillean NV on 15 December 1980 and withheld 25 per cent tax on the payment.

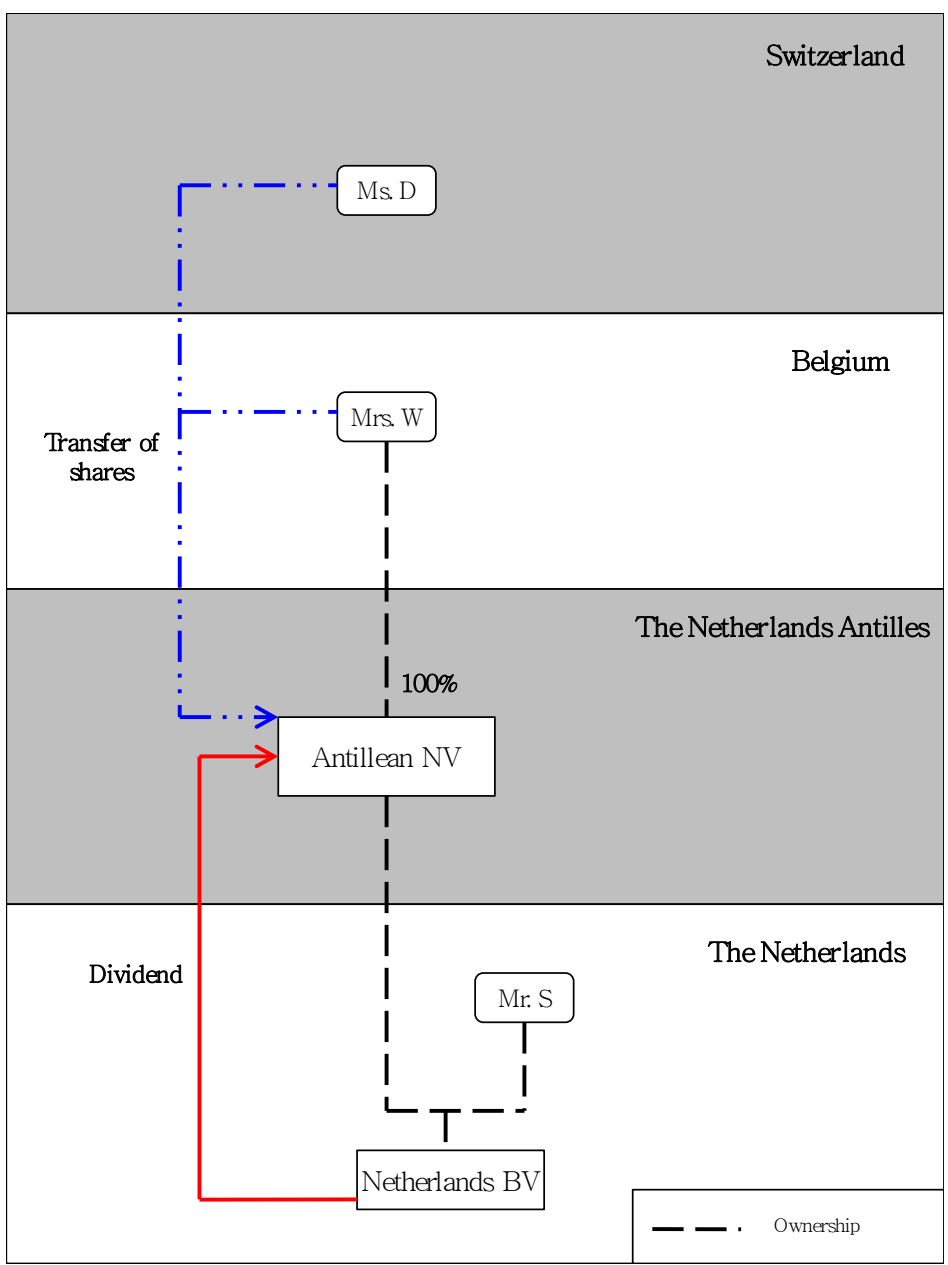

Figure 6.4: The $W$-family 2 case

Antillean NV applied to the Dutch Tax Inspector for a refund of the Dutch withholding tax under Article 11(3) of 
the BRK. The inspector denied the refund because (author's translation): ${ }^{513}$

Antillean NV was a "paper company" established with the objective of obtaining a reduction of withholding tax on dividends distributed by the Dutch corporations. Accordingly, a legal situation has been created almost solely with the purpose of unjustified avoidance of taxation, as a result of which the object and purpose of the Dividend Tax Act 1965 and [the BRK] were ignored.

The lower court of Arnhem decided in favour of the tax inspector. Referring to its findings in the $W$-family 1 case, the court emphasised the fact that Mrs. W and Ms. D transferred their shares in Dutch BV solely for avoiding tax. It held that Antillean NV failed to show why the transfer of Netherlands BV's shares to Antillean NV should not be assessed differently. It was of the opinion that the fact that Netherlands BV had not bought back its shares should not affect the assessment. ${ }^{514}$

On appeal, however, the Hoge Raad decided in favour of Antillean NV. It was of the opinion that the lower court had no sound reason to follow its findings in the $W$-family $l$ case. ${ }^{515}$ Differentiating the facts of the present case from the $W$-family 1 case, the court observed (author's translation): ${ }^{.16}$

The [lower court's decision in the $W$-family 1 case] ... refers to an acquisition of [Dutch BV's] shares by [Antillean NV] or a transfer of shares in [Dutch BV] to [Antillean NV] in which it was certain that the shares in connection with such a purchase or transfer would be purchased by [Dutch BV].

In the present case, however, neither the acquisition of shares of [Netherlands BV] nor the contribution of such shares in [Antillean NV] is followed by a

\footnotetext{
513 "[Tekst] ARREST" in $W$-family 2, above n 512, at para 3.1.4 (emphasis added).

514 “HOF Arnhem 28 juni 1991 (Nr. 1694/1988)" in $W$-family 2, above n 512, at para 4.2 .

515 "[Tekst] ARREST" in $W$-family 2, above n 512, at para 3.2.3.

${ }^{516}$ Ibid. See also Stef van Weeghel The Improper Use of Tax Treaties: with Particular Reference to the Netherlands and the United States (Kluwer, London, 1998) at 171.
} 
corresponding purchase of these shares by the [Dutch private company] ...

The mere circumstance that the shares in [Netherlands BV] were contributed to or sold to [Antillean NV] solely for tax reasons does not lead to the conclusion that there was a contravention of the object and purpose of the BRK and the law.

The facts ... that [Antillean NV] is a company incorporated in a country with a low tax burden, that [Antillean NV] is not involved in economic activity of its own - in the sense of business activity - or does it only incidentally, and that [Antillean NV] is a resident in the country with the low tax burden simply because of its incorporation there by fiction of law, form insufficient grounds for a different conclusion.

Although the Hoge Raad did not accept the findings of the lower court in the $W$-family 1 case, it still followed the approach adopted by the lower court in that case.

In $W$-family 2 , the Hoge Raad seized on the absence of the redemption of the share by Netherlands BV to distinguish the present case from $W$-family 1 . The court allowed treaty benefits to Antillean NV because Netherlands BV did not redeem its shares. In the absence of the redemption of the shares by Netherlands BV, the series of transactions remained incomplete and the link between them was broken. Because there was no link, the court did not consider Antillean NV to act as a conduit. ${ }^{517}$ It is clear that the court ignored the importance of facts such as the non-involvement of Antillean NV in economic activity and its location.

The reasoning does not make sense. An incomplete series of transactions may cause the link to break, but other facts together may contribute to show that an interposed company acts as a conduit. The reasoning of the Swiss Federal Tax Administration in X-group $1979^{518}$ is a good example.

\footnotetext{
${ }^{517}$ Also see "Noot" in $W$-family 2, above n 512, at para 7.

${ }^{518}$ X-group 1979 (1979) 48 Archives de droit fiscal Suisse 271 (The Federal Tax Administration, Switzerland).
} 


\subsection{The $X$-group 1979 case}

Recalling the facts from section 3.12, in X-group 1979, Mr. N, a German resident, owned shares in four Swiss companies, which had accumulated profits. If $\mathrm{Mr}$. $\mathrm{N}$ had received dividends directly from them, he would have incurred Swiss withholding tax at the rate of 15 per cent under the Switzerland-Germany double tax treaty of 11 August 1971. ${ }^{519}$

Dividends distributed by Swiss companies to Dutch companies qualified for a total withholding tax refund under Article 9(2)(a)(i) of the Switzerland-Netherlands double tax treaty of 12 November $1951 .{ }^{520}$ Thus, in order to obtain the Swiss withholding tax refund, Mr. N transferred the shares of the Swiss companies to $\mathrm{X}$ Amsterdam, an interposed Dutch company, via two other interposed companies located in Panama and the Netherlands Antilles. The parties participated in a series of transactions in which the purchaser acquired the shares with the help of a loan from the seller. Similar transactions occurred in subsequent acquisitions of shares of the Swiss

${ }^{519}$ Convention for Avoidance of Double Taxation and the Prevention of Fiscal Evasion with Respect to Taxes on Income and Capital, Switzerland-Germany (11 August 1971, entered into force 29 December 1972), art 10(2)(c).

${ }^{520}$ Protocol to the Convention for Avoidance of Double Taxation and the Prevention of Fiscal Evasion with Respect to Taxes on Income and Property, Switzerland-the Netherlands (12 November 1951, entered into force 22 December 1966) art 9(2)(a)(i). It provided: "In the case of tax on income from movable capital levied by one of the two States by deduction at source, the recipient of such income domiciled in the other State may, within a period of two years, request reimbursement through the State in which he is domiciled, subject to the production of an official certificate of domicile and of liability to direct taxation in the State of domicile:

a) in case of dividends:

(i) in the total amount of tax withheld if the recipient of such dividends is an entity whose capital wholly or partly consist of shares and which owns at least 25 per cent of the voting stock of the entity paying the dividends, provided the relation between the two entities has not been constituted or maintained primarily for purpose of assuring receipt of the total fund." 
companies by the interposed companies. A condition in the loan contracts was that the repayment of debts would be only out of dividend income.

The Swiss companies distributed dividends to $\mathrm{X}$ Amsterdam after deducting 25 per cent Swiss withholding tax. When X Amsterdam requested a full refund from the Swiss Federal Tax Administration under Article 9(2) of the Switzerland-Netherlands double tax treaty of 12 November $1951,{ }^{521}$ the administration allowed only a partial refund.

Under, Article 9(2)(a)(i) a Dutch company was allowed a total refund of Swiss withholding tax on dividends distributed by a Swiss company only if the relationship between the two companies was not established, or was not maintained, primarily in order to obtain the benefit of such total reimbursement. ${ }^{522}$ In order to determine whether the relationship between the Swiss corporations and $\mathrm{X}$ Amsterdam was established primarily to obtain the refund of the Swiss withholding tax, the Swiss Tax Administration considered the arrangement in its entirety. It clarified that it was concerned with the means by which the arrangement was implemented, rather than the motive of Mr. N. ${ }^{523}$

By contrast, as discussed in section 6.11, in the $W$ family 1 case $^{524}$ the issue of whether the transactions were interlinked, or whether the parties achieved the alleged

\footnotetext{
${ }^{521}$ Protocol to the Convention for Avoidance of Double Taxation and the Prevention of Fiscal Evasion with Respect to Taxes on Income and Property, Switzerland-the Netherlands (12 November 1951, entered into force 22 December 1966) art 9(2)(a)(i).

522 The Netherlands-Switzerland double tax treaty of 12 November 1951, above n 141, art 9(2)

${ }^{523}$ X-group 1979, above n 518, at 275.

${ }^{524} W$-family 1 (18 May 1994) Case no 28 293, BNB 1994/252 (the Hoge Raad, the Netherlands).
} 
end result, depended upon the question of whether they intended to achieve the end result. That is, the answer to the question of what was the effect of the end result depended on the intention of the parties.

The issue of whether an arrangement is contrary to the object and purpose of a double tax arrangement should be determined independently of a taxpayer's intention. The intention of the parties does not necessarily help to determine the issue of whether the arrangement is contrary to the object and purpose of a double tax treaty because its effect may differ from the parties' intention.

\subsection{Consideration of the arrangement as a whole}

As with the Dutch courts in $W$-family 1 and $W$-family 2, the Swiss Federal Tax Administration took into account the series of transactions and the loan contracts between the interposed companies; ${ }^{525}$ however, unlike the Dutch courts, the administration also considered the fact that $\mathrm{X}$ Amsterdam's economic role was of secondary importance or was virtually non-existent. ${ }^{526}$ It noted that $\mathrm{X}$ Amsterdam had performed few financial transactions and that there was no economic relationship between it and the Swiss companies. ${ }^{527}$ It also pointed out that the interposed companies were located either in countries where income from participation was exempted generally from all taxes or countries that had an extended network of tax treaties. $^{528}$

The approach adopted by the Swiss Federal Tax Administration shows that the link between transactions cannot be logically regarded as decisive. Although the

\footnotetext{
${ }^{525}$ X-group 1979, above n 518, at 277.

${ }^{526}$ Ibid, at 275 .

${ }^{527}$ Ibid, at 275.

${ }^{528}$ Ibid, at 277.
} 
presence of a link between transactions indicates that a company interposed in the other contracting state is a conduit, the absence of a link does not necessarily show that the interposed company does not act as a conduit.

If the facts of $W$-family 2 are analysed with the help of the reasons for existence approach, different conclusions may be drawn.

\subsection{Reasons for the existence of Antillean NV}

The facts that Antillean NV did not carry out business activity and was located in a tax haven suggest that Antillean NV acted as a conduit with respect to dividends, even though it was the legal owner of Netherlands BV's shares.

As with $W$-family 2, the parties in X-group $1979^{529}$ transferred income-generating assets to the immediate recipient, X Amsterdam. As well, in X-group 1979 the Swiss subsidiaries did not redeem their shares but distributed dividends to $\mathrm{X}$ Amsterdam. If the Swiss Federal Tax Administration had used the link between transactions test, it would have considered X Amsterdam to be the beneficial owner for two reasons. First, the series of transactions was incomplete, and therefore, the administration would have considered the link to be absent. Second, because X Amsterdam was the legal owner of the shares, the administration would have regarded it as the beneficial owner of the dividends. However, the Swiss Federal Tax Administration did not allow treaty benefits to X Amsterdam because, unlike the Hoge Raad, it considered the arrangement as a whole.

${ }^{529}$ X-group 1979 (1979) 48 Archives de droit fiscal Suisse 271 (The Federal Tax Administration, Switzerland). 
In his case note on $W$-family 2, P.J. Wattel observed (author's translation): ${ }^{530}$

As the [lower court] decided quite rightly, the fact that in [ $W$-family 2] no redemption (but normal distribution) occurred, which did occur in [W-family 1$]$, is ... not decisive. It is not about the coincidental form of distribution of profits by [Dutch BV] and [Netherlands $\mathrm{BV}$ ] to [Antillean NV], but about the question whether an indissoluble connection existed between the distribution of profits by [Dutch BV] and [Netherlands BV] to [Antillean NV] respectively and the preceding contribution to [Antillean NV] of shares of [Dutch BV] and [Netherlands BV] respectively, which had accumulated profits ready to be distributed.

Wattels's observation suggests that in addition to a link between transactions that shows a flow of incomegenerating assets from a resident state to a source state, courts should also consider a link between transactions that shows a flow of passive income from the source state to the resident state.

Antillean NV seems to have no reasons for existence other than to obtain the benefits of a Dutch withholding tax reduction under the BRK. ${ }^{531}$ Mrs. W and Ms. D transferred their shares in several Dutch companies to Antillean NV. Antillean NV appeared to carry out no other activity than to hold these shares. As the Netherlands Antilles does not impose withholding tax on the outgoing dividends, the location of the Antillean NV ensured that dividends flowed from the Dutch companies in general and Netherlands BV in particular ultimately to Mrs. W in Belgium and Ms. D in Switzerland. For these reasons, the arrangement appears to be contrary to the object and purpose of the BRK.

\footnotetext{
${ }^{530}$ Also see "Noot" in $W$-family 2, above n 524, at para 7.

${ }^{531}$ Tax Arrangement for the Kingdom of the Netherlands (28 October 1964, entered into force 12 December 1985), art 11(3).
} 


\subsection{Conclusion}

The scope of the step transaction doctrine is a facet of the substance over form doctrine. It should catch any shenanigan that leads the benefit of a double tax treaty to flow to a non-resident. The United States and Dutch courts, however, limited its scope by over emphasising the significance of the presence of a link between transactions where the parties transfer income generating assets from the resident state to the source state. As a consequence, the courts failed to consider the arrangement as a whole.

In a conduit company case, an examination of an arrangement is not limited to determining whether a substantive link exists between transactions that show a one-way flow of assets from the resident state to the source state. It also involves transactions that show a flow of passive income from the source company to the resident company, and facts such as the absence of a substantive business activity and the location of interposed companies in a tax haven or a country that imposes low income tax. These facts together may show that an interposed company has no reasons for existence in a corporate structure, even though the parties transferred income generating assets from the resident state to the company that immediately received passive income, not to the company in the source state.

Nevertheless, because of adopting a narrow approach, the United States and Dutch courts essentially based their decisions on a formal link rather than a substantive link between transactions. In Del Commercial, ${ }^{532}$ the United States courts considered similarities between terms and conditions of contracts to indicate a link between

532 Del Commercial Properties Inc $v$ Commissioner of Internal Revenue TC Memo 411 (1999). Del Commercial Properties Inc v Commissioner of Internal Revenue 251 F 3d 210 (2001), at 216. 
transactions. SDI Netherlands ${ }^{533}$ shows that even if terms and conditions differ, the arrangement can still contradict the object and purpose of a double tax treaty. Further, in $W$-family $1,{ }^{534}$ the Dutch courts regarded the intention of the parties to reach an end result as an indicator of the link between the individual steps. The intention of the parties does not necessarily help determine the issue of whether the arrangement is contrary to the object and purpose of a double tax treaty because the effect of such an arrangement may differ from the intention of the parties. $W$-family $2^{535}$ illustrates that an interposed company act as a conduit even when the parties had no intention to achieve the end result of transferring income generating assets to the source state.

The presence of a link between transactions indicates that interposed companies in general, and the immediate recipient in particular, act as conduits; its absence, however, does not necessarily show that the immediate recipient does not act as a conduit.

${ }^{533}$ SDI Netherlands BV $v$ Commissioner of Internal Revenue, above $\mathrm{n}$ 499.

${ }^{534}$ See "HOF Arnhem 28 juni 1991 (Nr. 1658/1988)" in W-family 1 (18 May 1994) Case no 28 293, BNB 1994/252 (the Hoge Raad, the Netherlands), at para 4.5 (emphasis added).

${ }^{535} W$-family 2 (18 May 1994) Case no 28 296, BNB 1994/253 at para 4 (the Hoge Raad, the Netherlands). 



\section{CHAPTER 7}

\section{CONCLUSION}

7. Conclusion

7.1. The underlying theory

7.2. A pragmatic position

7.3. Difficulties for courts

7.4. The nature of general anti-avoidance rules ......... 278

7.5. The nature of the beneficial ownership clause .... 280

7.6. Narrow approach does not help ......................... 283

7.7. Significance of the term "beneficial owner" ....... 286

7.8. "Beneficial owner": a distraction in conduit company cases

7.9. "Reasons for existence": an alternative approach 293

7.10. Beneficial ownership is not an additional requirement....................................................... 295

7.11. The "activity provision" ...................................... 298

7.12. Reference to paragraph 14(b) of the Conduit Companies Report. 301

\subsection{The underlying theory}

According to Prebble's thesis of "ectopia", 536 income tax law is fundamentally dislocated from the reality of its subject matter. The explanation for the difficulty in applying the beneficial ownership test to conduit company cases can be viewed as a particular application of this theory.

Because double tax agreements are international treaties, they should be interpreted liberally and according to Article 31 of the Vienna Convention on the Law of Treaties, ${ }^{537}$ which states that a treaty should be interpreted in accordance with the ordinary meaning given to its terms in their context, and in the light of its object and purpose. ${ }^{538}$ In addition to the prevention of double taxation

\footnotetext{
${ }^{536}$ John Prebble "Can Income Tax Law be Simplified?" (1996) 2 NZ Journal of Taxation Law and Policy 187 at 189.

${ }^{537}$ Vienna Convention on the Law of Treaties (23 May 1969, entered into force 27 January 1980).

${ }^{538}$ Ibid, art 31(1). It states: "A treaty shall be interpreted in good faith in accordance with the ordinary meaning to be given to the terms of the treaty in their context and in the light of its object and purpose."
} 
of income between contracting states, a significant purpose of a double tax agreement is to limit its benefits to residents of the contracting states. In the light of this purpose, the treaty's provisions should be accorded a substantive economic interpretation.

Generally, double tax agreements are based on the OECD Model Convention, which prevents the double taxation of passive income by reducing the tax withheld in the country of the origin of passive income, ${ }^{539}$ and in part by reducing tax by exemption ${ }^{540}$ or credit $^{541}$ in the destination state. In order to limit the benefit of a (withholding) tax reduction, the convention requires the recipient of passive income to be its beneficial owner. In the light of the purpose of limiting treaty benefits, the term "beneficial owner" indicates that a person should own passive income in a substantive economic sense.

It is logically possible to decide whether an individual is entitled to treaty benefits on the basis of beneficial ownership. It is logically impossible, however, to use beneficial ownership as a test for deciding whether a company is entitled to treaty benefits. In a substantive economic sense, a company cannot be considered to be the owner of its income. When a company receives income, its shareholders are economically better off. From this consideration, it follows that companies should never be entitled to treaty benefits. This inference does not deny the fact that in appropriate circumstances, shareholders should be so entitled to treaty benefits if they are residents in one of the contracting states. Yet, the OECD Model Convention

\footnotetext{
539 OECD Committee on Fiscal Affairs Model Tax Convention on Income and on Capital (OECD, Paris, 2008), arts 10(2), 11(2) and 12(1).

${ }^{540} \mathrm{Ibid}, \operatorname{art} 23 \mathrm{~A}(1)$.

${ }^{541}$ Ibid, art 23A(2).
} 
applies the beneficial ownership test to companies. The point is that this test, as it operates in double tax treaties, is dislocated from the substantive economic reality of corporations.

\subsection{A pragmatic position}

The OECD Model Convention assumes that companies, at least in some cases, can be considered the beneficial owners of income. Its assumption is based on the legal perspective, which, in contrast to the substantive economic perspective, views companies as entities separate from their shareholders. From a legal perspective, companies own their assets legally as well as beneficially, simply by virtue of being separate entities. ${ }^{542}$

The position of the OECD Model Convention can be appreciated in the light of Fuller's theory of legal fictions, ${ }^{543}$ according to which the term "fiction" implies that, although the statement under discussion is false, it is useful. Despite being founded on the substantive economic perspective, the OECD Model Convention adopts a legal perspective because the latter is useful for trade and commerce. This position can hold in cases where shareholders of a recipient company are residents of the state in which the company is located. It is problematic, however, in conduit company cases that involve a recipient company the shareholders of which are residents in a state other than the contracting states. Because the OECD Model Convention assumes that such a company can be considered to be a beneficial owner, it allows treaty benefits to persons that are residents of a non-contracting state in a substantive economic sense. Consequently, it

\footnotetext{
${ }^{542}$ Eisner v Macomber 252 US 189 (1920).

${ }^{543}$ Lon L Fuller Legal Fictions (Stanford University Press, Stanford, 1967).
} 
contradicts its generic policy, which is to limit its benefits to residents of contracting states.

\subsection{Difficulties for courts}

When it comes to interpreting the term "beneficial owner" and applying it to conduit company cases, courts often struggle to reconcile opposing perspectives. Because they are obliged to determine whether to honour claims to treaty benefits made by a recipient company, they often prefer to employ a legal perspective. Their position can also be explained by referring to Fuller's theory. Their preference to adopt a legal perspective can be attributed generally to their desire to maintain the stability of tax law.

The Authority for Advance Rulings of India faced these opposing perspectives in its NatWest Ruling. ${ }^{544}$ As discussed in section 2.23, in the NatWest Ruling a bank resident in the United Kingdom acquired shares in an Indian bank through two wholly owned Mauritian subsidiaries. The authority had to decide whether the Mauritian subsidiaries qualified as the beneficial owners of the dividends paid by the Indian bank under Article 10 of the India-Mauritius double tax treaty of 24 August 1982. ${ }^{545}$ The ruling shows that the authority appreciated that it should accord a substantive economic interpretation to the term "beneficial owner" in the light of the policy to ensure that treaty benefits are limited to residents of contracting states. In a substantive and economic sense, the bank in the United Kingdom was the beneficial owner

${ }^{544}$ In Re XYZ (1996) 220 ITR 377 (AAR) (The Authority for Advance Rulings, India).

${ }^{545}$ Convention for Avoidance of Double Taxation and the Prevention of Fiscal Evasion with Respect to Taxes on Income and Capital Gains, India-Mauritius (24 August 1982, entered into force 6 December 1983), art 10(2). 
of the dividends. However, the authority found itself bound by the conventional legalistic perspective, according to which the Mauritian subsidiaries were the beneficial owners of the dividends by virtue of being separate entities. The authority was unable to reconcile the two perspectives. Probably for this reason, it decided not to apply the beneficial ownership test. Instead, it considered chronological events and ruled against the Mauritius subsidiaries on the grounds that, prima facie, the transaction was designed for tax avoidance. ${ }^{546}$

The NatWest Ruling is an extreme example of a case in which the deciding authority preferred not to apply the beneficial ownership test at all. Generally, however, courts justify their approach by adopting surrogate tests, as explained in this thesis, in place of an actual beneficial ownership test. When applying these tests, courts have failed to connect their conclusion logically to their reasoning because the criteria by which they work do not employ the concept of beneficial ownership. Doing their best, courts, commentators and the OECD have attributed the difficulty in interpreting and applying the beneficial ownership concept to the absence of an accurate definition. But, because the beneficial ownership concept cannot be applied logically, clarifying its meaning may be of little help.

In the light of the purpose of limiting treaty benefits to residents of contracting states, the nature of provisions that limit the right of the source state to impose withholding tax resembles general anti-avoidance rules and judicial

${ }^{546}$ The Income Tax Act 1961 (India), s 245R(2)(c). S 245R(2)(c) provides that the Authority for Advance Rulings shall not allow an application, if after examining it the Authority is of the opinion that the application was related to a transaction that was designed prima facie for tax avoidance. 
anti-avoidance doctrines. As with general anti-avoidance rules, these provisions are general by nature. From this consideration, the term "beneficial owner" simply calls for an application of a substantive approach to the investigation of a tax-planning arrangement. It does not make sense to assign a strict linguistic meaning to the term and apply it as a test of ownership. Doing so results in specifying criteria against which an arrangement shall be tested. Examining the facts against specific criteria often results in a formal legalistic analysis. The following few sections illustrate the argument.

\subsection{The nature of general anti-avoidance rules}

As the name suggests general anti-avoidance rules are general. Judicial anti-avoidance doctrines such as substance over form and the abuse of law are also general. This general nature does not mean that these rules and doctrines catch all attempts to minimise tax burdens. It means that they determine whether a disputed arrangement qualifies for tax benefits on the basis of a substantive analysis that does not test the arrangement against specific criteria. Lord Denning's approach in L.J. Newton $v$ Federal Commissioner of Taxation ${ }^{547}$ illustrates the point. He dealt with section 260 of the Income Tax and Social Services Contribution Assessment Act 1936-1950, which was the former Australian general anti-avoidance rule. ${ }^{548}$

\footnotetext{
${ }^{547}$ L J Newton v Federal Commissioner of Taxation (1958) 98 CLR 1 (Privy Council, Australia).

${ }^{548}$ The Income Tax and Social Services Contribution Assessment Act 1936-1950 (Australia), s 260. The relevant part of s 260 provided:
}

"Every contract, agreement, or arrangement made or entered into, orally or in writing ..., shall so far as it has or purports to have the purpose or effect of in any way, directly or indirectly-(a) altering the incidence of any income tax; (b) relieving any person from liability to pay income tax or make any return; (c) defeating, evading, or avoiding any duty or liability imposed on any person by this Act; or (d) 
As discussed in section 3.3, the Newton case involved a dividend stripping scheme in which a company's shareholders sold their shares to a share broker at a price equal to the anticipated dividend. The broker received the dividend and sold the shares back to the shareholders at a loss. The arrangement was designed for the shareholders to avoid tax on their dividend by converting it into capital gains.

The Australian Federal Commissioner of Taxation assessed the shareholders for income tax. He applied section 260 on the grounds that the transactions formed a part of an initial plan that was carried out to achieve the end of tax avoidance. The shareholders' argument was that the interpretation accorded to the provision by the Commissioner was too wide to cover all transactions by which taxpayers seek to reduce their tax burdens.

Lord Denning decided in favour of the Commissioner. Clarifying the scope of section 260, he observed that the provision covered arrangements that have the effect of avoiding tax. That is, it caught arrangements that resulted in a contradiction of the purpose of the legislation. It concerned ways a taxpayer avoids tax, rather than his motive. Lord Denning explained that decision-making authorities must consider the arrangement as a whole. In order to bring an arrangement under section 260, authorities may examine overt acts by which the arrangement was implemented; and on the basis of this examination, predicate that the arrangement was so implemented in order to avoid tax.

Lord Denning's approach is commonly referred to as the "predication test". There are two relevant features of

preventing the operation of this Act in any respect, be absolutely void ..." 
his approach. First, it interpreted the provision in the light of the purpose of legislation. Second, it preserved the general nature of the general anti-avoidance rule. That is, it did not specify criteria that would allow or disallow tax benefits to taxpayers.

It does not make sense to specify criteria for applying a general anti-avoidance rule because doing so constricts the scope of the rule. It limits the ability of the decisionmaking authority to apply a substantive analysis. Specifying criteria enables taxpayers to comply with the law in form, not in substance.

\subsection{The nature of the beneficial ownership clause}

An analogy can be drawn between the function of the provisions that limit the right of the source state to impose withholding tax on one hand and general anti-avoidance rules or judicial anti-avoidance doctrines on the other. When taxpayers claim a withholding tax reduction, they intend to reduce tax. The provisions that reduce the amount of withholding tax allow a tax reduction only if the arrangement is in alignment with the purpose of a double tax treaty to restrict tax benefits to residents of contracting states. The approach adopted by the Swiss Tax Administration to interpret and apply Article 9(2)(a)(i) of the Switzerland-Netherlands double tax treaty of 12 November $1951^{549}$ illustrates the point.

As discussed in section 3.12, X-group $1979^{550}$ involved a German individual who owned shares in certain Swiss companies. In order to obtain a refund of Swiss

\footnotetext{
${ }^{549}$ Protocol to the Convention for Avoidance of Double Taxation and the Prevention of Fiscal Evasion with Respect to Taxes on Income and Property, Switzerland-the Netherlands (12 November 1951, entered into force 22 December 1966) art 9(2)(a)(i).

${ }^{550}$ X-group 1979 (1979) 48 Archives de droit fiscal Suisse 271 (The Federal Tax Administration, Switzerland).
} 
withholding tax under Article 9(2)(a)(i) of the Switzerland-Netherlands double tax treaty of 12 November 1951, he interposed a Dutch company. He also interposed companies in the Netherlands Antilles and Panama. Subsequently, he transferred his shares to the Dutch subsidiary, via the other interposed companies, in a series of transactions that involved an acquisition of shares in return for a loan from the seller.

The anti-abuse clause in Article 9(2)(a)(i) allows a refund if "the relation between the two entities has not been constituted or maintained primarily for the purpose of assuring receipt of the total fund". ${ }^{551}$ According to the Swiss Federal Tax Administration, the provision was designed to prevent persons who were neither residents of Switzerland nor residents of the Netherlands from obtaining a full refund of Swiss withholding tax. By implication, the provision determined whether the effect of the interposition of the Dutch company contradicted the purpose of the treaty, which was to limit tax benefits to Swiss and Dutch residents. The Administration clarified further that the provision did not require an investigation of motives for interposing the Dutch company.

When applying Article 9(2)(a)(i), the Administration considered the arrangement as a whole. On examining the business activities of the interposed companies, their locations and the loan contracts between them, it concluded that there were no "serious economic reasons" 552 for the existence of the Dutch company. For this reason, it did not allow a Swiss withholding tax refund. This thesis refers to the Swiss Federal Tax

\footnotetext{
${ }^{551}$ X-group 1979, above n 550.

${ }^{552} \mathrm{Ibid}$, at 275.
} 
Administration's approach as the "reasons for existence" approach.

The Swiss Federal Tax Administration did not refer to the Newton case. Nevertheless, it is clear that, not only did it interpret Article 9(2)(a)(i) along the same lines as Lord Denning, its approach for applying this provision resembles Lord Denning's approach. These similarities imply that, as with general anti-avoidance rules and judicial anti-avoidance doctrines, the provisions that reduce withholding tax are by nature general. The implication is further supported by Del Commercial Properties Inc v Commissioner of Internal Revenue, ${ }^{553}$ in which courts used the United States step transaction doctrine in order to apply Article VI of the United StatesNetherlands double tax treaty of 29 April $1948 .{ }^{554}$

The step transaction doctrine is a facet of the United States substance over form approach. The doctrine treats individual steps in a series of transactions as a single transaction, if a substantive link exists between them. The application of this doctrine to conduit company cases should deny treaty benefits to any arrangement that in substance results in passing on of these benefits to residents of non-contracting states. However, because the United States courts in Del Commercial restricted the potential of the doctrine, they also narrowed down the scope of the withholding tax provision. Consequently, they impaired the ability of the relevant treaty provision to

553 Del Commercial Properties Inc $v$ Commissioner of Internal Revenue TC Memo 411 (1999). Del Commercial Properties Inc $v$ Commissioner of Internal Revenue 251 F 3d 210 (2001).

554 Supplementary Convention Modifying and Supplementing the Convention with Respect to Taxes on Income and Certain other Taxes (30 December 1965, entered into force 8 July 1966), art VI. 
implement effectively the policy to restrict treaty benefits to residents of contracting states.

\subsection{Narrow approach does not help}

As discussed in section 6.6, in Del Commercial a Canadian company borrowed a loan from the Royal Bank of Canada and transferred the principal amount to a United States company through a series of transactions via interposed companies in Canada, the Cayman Islands, the Netherlands Antilles and the Netherlands. All companies were affiliated to the same group. The arrangement was implemented in order to obtain the United States withholding tax exemption on interest payments under Article VI of the United States-Netherlands double tax treaty of 29 April 1948.

The United States Tax Court and the United States Court of Appeals for the District of Columbia Circuit applied the step transaction doctrine and denied the withholding tax exemption. They found that there was a close correspondence in interest rates and repayment schedules of contracts for the loan made by Royal Bank of Canada and the loan made by the Dutch interposed company. In their opinion, the close correspondence showed that loan transactions were mutually interdependent. The courts indicated that if the Dutch company had earned a profit spread on the inflow and outflow of interest payments, they would not have considered it as a conduit.

The United States Tax Court and the United States Court of Appeals for the District of Columbia Circuit found that there was a close correspondence in interest rates and repayment schedules of contracts for the loan made by Royal Bank of Canada and the loan made by the interposed Dutch company. In their opinion, the close 
correspondence showed that loan transactions were mutually interdependent. They applied the step transaction doctrine and concluded that in substance the United States company paid interest directly to the Canadian company, not to the Dutch interposed company. Because granting a withholding tax exemption in such a situation would be against the policy of the United States Netherlands double tax treaty, the courts denied the tax exemption.

The fact that the courts used the step transaction doctrine to apply Article VI of the United StatesNetherlands double tax treaty confirms the point that the operation of provisions that limit the right of the source state to impose withholding tax is analogous to the function of judicial anti-avoidance doctrines. The approach also shows that the courts interpreted Article VI using the right frame of reference.

The problem with the courts' reasoning is that they indicated that if the Dutch company had earned a profit spread on the inflow and outflow of interest payments, they would not have considered it as a conduit. This reasoning implies that the doctrine only applies to arrangements in which a link between transactions exists. An absence of such a link, however, does not necessarily show that an interposed company does not pass on passive income to residents of non-contracting states. As indicated earlier, the courts narrowed the scope of the step transaction doctrine. Although no conduit company case has applied the step transaction doctrine since the Del Commercial case, the illogicality of the reasoning in the Del Commercial case was exposed in SDI Netherlands $B V v$ Commissioner of Internal Revenue. ${ }^{555}$

${ }^{555}$ SDI Netherlands BV v Commissioner of Internal Revenue $107 \mathrm{TC}$ 161 (1996). 
As discussed in section 6.18, in SDI Netherlands a Bermudan company licensed software to a Dutch company, which in turn sub-licensed the software to a United States company. The purpose of the arrangement was to obtain an exemption from the United States tax on royalty payments from the United States company under Article IX of the United States-Netherlands double tax treaty of 29 April $1948 .^{556}$

The court found that the terms of the two licensing agreements differed. The difference allowed the Dutch company to earn a profit spread on the inflow and outflow of royalties. On the basis of the finding, the court accorded a separate status to the two agreements. That is, it concluded that no link existed between the transactions. It held, therefore, that royalty payments from the Dutch company to the Bermudan company did not constitute income received from a source within the United States. It allowed the exemption from United States withholding tax. Effectively, the court treated the absence of the link between transactions as sufficient to show that the Dutch company did not act as a conduit.

Unlike the courts in Del Commercial, the court in SDI Netherlands did not apply the step transaction doctrine; however, the underlying logic of the courts in the two cases was the same. In the light of the similarity, it is possible that courts will not apply the step transaction doctrine if they find that the link between transactions does not exist. The point is that by narrowing the scope of the step transaction doctrine, the courts in Del Commercial limited the scope of Article IX of the United StatesNetherlands double tax treaty. Consequently, they

\footnotetext{
${ }^{556}$ The United States-Netherlands double tax treaty of 29 April 1948, above $\mathrm{n} 554$, art IX(1).
} 
constricted the ability of the provision to implement effectively the policy of limiting treaty benefits to residents of the contracting states.

Further, as analysed in section 6.25, an application of the "reasons for existence" approach to the SDI Netherlands case shows that the court ignored factors indicating that the Dutch company acted as a conduit. The application of that approach leads to a more logical conclusion. Because the approach preserves the general nature of the provisions that reduce withholding tax, the analysis in section 6.25 further supports the argument that, as with general anti-avoidance rules, it does not make sense to specify criteria by which such provisions should work.

\subsection{Significance of the term "beneficial owner"}

Because of the general nature of the provisions that limit the right of the source state to impose withholding tax, the term "beneficial owner" has a different significance from other terms that need interpretation to determine their ordinary meaning in the context of the object and purpose of a double tax treaty. "Beneficial owner" does not carry a linguistic meaning of its own. It simply indicates that a substantive analysis should be applied for deciding whether an arrangement qualifies for treaty benefits. This approach was adopted by the United States Tax Court in Aiken Industries Inc $v$ Commissioner of Internal Revenue. ${ }^{557}$ Aiken Industries concerned the United StatesHonduras double tax treaty of 26 June $1956 .{ }^{558}$ Even

557 Aiken Industries Inc v Commissioner of Internal Revenue $56 \mathrm{TC}$ 925 (1971).

${ }^{558}$ Convention for Avoidance of Double Taxation and the Prevention of Fiscal Evasion with Respect to Taxes on Income, the United States-Honduras (25 June 1956, entered into force 6 February 1957). The convention was terminated on 31 December 1966. 
though the treaty did not contain the expression "beneficial owner", the United States Tax Court applied what was clearly the policy of the treaty requiring that the person who gets treaty benefits should be the resident of the jurisdiction that was genuinely meant to get benefit.

As discussed in section 2.4, Aiken Industries involved a back-to-back loan structure, in which Ecuadorian Ltd, a Bahamian parent company, interposed Industrias, a Honduran company, between itself and Aiken, a United States subsidiary. Ecuadorian Ltd implemented the arrangement in order to obtain the exemption from United States tax on the interest payments by Aiken under Article IX of the United States-Honduras double tax treaty. When applying Article IX, the United States Tax Court considered the arrangement as a whole. It determined the issue of whether the contractual obligations of Industrias had substance. The court noted that transactions occurred between related parties and that Industrias was left with the same inflow and outflow of funds. On the basis of these facts, it concluded: ${ }^{559}$

$$
\begin{aligned}
& \text { Industrias was merely a conduit for the passage of } \\
& \text { interest payments from [Aiken] to [Ecuadorian Ltd]. } \\
& \text { Industrias had no actual beneficial interest in the interest } \\
& \text { payments it received, and in substance, [Aiken] was } \\
& \text { paying the interest to [Ecuadorian Ltd.] which } \\
& \text { "received" the interest within the meaning of article IX. }
\end{aligned}
$$

Two related points emerge. First, as with Lord Denning in the Newton case, ${ }^{560}$ the United States Tax Court did not specify criteria that would have allowed treaty benefits to Industrias. That is, it generalised the provision. The approach adopted by the United States Tax Court further supports the argument that the provisions that reduce the

559 Aiken Industries Inc v Commissioner of Internal Revenue, above $\mathrm{n}$ 557, at 934 (emphasis added).

${ }^{560}$ L J Newton v Federal Commissioner of Taxation (1958) 98 CLR 1 (Privy Council, Australia). 
amount of withholding tax operate to limit treaty benefits in the same manner as general anti-avoidance rules operate to prevent domestic tax avoidance. Second, the court used the expression "beneficial interest" to represent a finding of its substantive analysis. It did not use the expression in a strict linguistic sense.

The court decided Aiken Industries before the term "beneficial owner" was introduced into the OECD Model Convention. The Netherlands Hoge Raad adopted the same approach in Y-group $1990,{ }^{561}$ which it decided after the term "beneficial owner" was inserted into the OECD Model Convention.

As discussed in section 3.5, in Y-group 1990, a Canadian company owned a Dutch subsidiary that generated profits. The Canadian company interposed an Antillean company that acquired certain shares of the Dutch subsidiary. The purpose of the arrangement was to avoid Dutch tax on a major portion of dividends that the Canadian company ultimately received through the Antillean subsidiary. The Hoge Raad had to determine whether the Antillean subsidiary was entitled to a refund of the Dutch withholding tax under Article 11(3) of the BRK. ${ }^{562}$ The court examined the facts in their totality and found that the Antillean subsidiary had no practical significance for the dividend payments in question. ${ }^{563} \mathrm{On}$

561 Y-group 1990 (28 June 1989) Case no 25 451, BNB 1990/45 (the Hoge Raad, the Netherlands).

${ }^{562}$ Tax Arrangement for the Kingdom of the Netherlands (28 October 1964, entered into force 12 December 1985), art 11(3). It stated: "The [dividend withholding tax] ... shall not be levied, or if so levied, shall be refunded with respect to dividends derived by an entity whose capital is wholly or partly divided into shares and which is a resident of the other country and holds at least 25 per cent of the paid-up capital of the company."

563 "Loop van het geding tot dusverre" in Y-group 1990, above n 561, at para 7.2 . 
the basis of this finding it held that the Canadian company, which enjoyed the dividend was not a resident of a country to which the BRK applied. The court therefore denied treaty benefits. It is debatable whether the Hoge Raad applied fraus legis, ${ }^{564}$ or whether it arrived at an independent fiscal determination on the facts. ${ }^{565}$ Regardless of that debate, it is clear that, as with Lord Denning $^{566}$ and the Swiss Federal Tax Administration, ${ }^{567}$ the Hoge Raad generalised the Dutch withholding tax provision.

Although Article 11(3) of the BRK did not use the term "beneficial owner", the Hoge Raad was of the opinion that its analysis of facts was consistent with Article 10(2) of the OECD Model Convention of $1977 .{ }^{568}$ The Advocate General presumed that the court intended to refer specifically to the beneficial ownership clause in Article 10(2) of the OECD Model Convention. ${ }^{569}$ The point is that, as with the United States Tax Court in Aiken Industries, the Hoge Raad considered that the beneficial ownership clause indicates that courts should apply a substantive analysis.

${ }^{564}$ See RLH IJzerman Het leerstuk van de wetsontduiking in het belastingrecht (Kluwer, Deventer, 1991), at 147. ECCM Kemmerem "De Hoge Raad heft de dividendbelasting afgeschaft" in Weekblad voor fiscal recht, No. 6141, 1995, at 360.

${ }^{565}$ See Stef van Weeghel The Improper Use of Tax Treaties: with Particular Reference to the Netherlands and the United States (Kluwer, London, 1998) at 160. Also see "Noot" in W-family 2 (18 May 1994) Case no 28 296, BNB 1994/253 at para 4 (the Hoge Raad, the Netherlands).

${ }^{566}$ L J Newton v Federal Commissioner of Taxation (1958) 98 CLR 1 (Privy Council, Australia).

${ }^{567}$ X-group 1979 (1979) 48 Archives de droit fiscal Suisse 271 (The Federal Tax Administration, Switzerland).

${ }^{568}$ See "Arrest" in Y-group 1990, above n 561, at para 7.2.

${ }^{569}$ See "Conclusie Advocaat-Generaal mr. Van Soest" in Y-group 1990, above n 549, at para 2.7 . 
The approach adopted by the courts in Aiken Industries and Y-group 1990 supports the point that the term "beneficial owner" does not carry a meaning of its own. It simply reminds courts and tax authorities to adopt a substantive approach.

\section{8. "Beneficial owner": a distraction in conduit company cases}

As indicated in section 7.1, an important object and purpose of a double tax treaty is to limit its benefits to residents of contracting states. Even before introducing the term "beneficial owner", the OECD Committee on Fiscal Affairs did not intend that residents of a non-contracting states could obtain a reduction in source state taxation under a convention simply by establishing a company in a contracting state. In a report on the discussion of the OECD Committee on Fiscal Affairs concerning the introduction of the term "beneficial owner" in the OECD Model Convention, the rapporteur observed: ${ }^{570}$

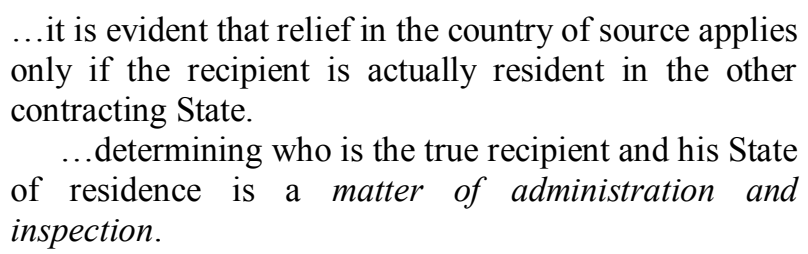

Two points emerge. First, the committee always intended that a reduction in source state taxation should be granted to anyone who is a resident of a contracting state and who in substance owns passive income. It introduced the term "beneficial owner" to make the intention explicit. $^{571}$

570 OECD Committee on Fiscal Affairs "Preliminary Report on Suggested Amendments to Articles 11 and 12 of the Draft Convention, relating to Interest and Royalties Respectively" FC/WP27 (68) 1, 30 December 1968, at 14 <www.taxtreatieshistory.org> (emphasis added).

571 OECD Committee on Fiscal Affairs " Proposal for the Amendment of Article 11 and 12 of the Draft Convention, Relating to Interest and 
Second, the expression "matter of administration and inspection" suggests that the committee did not intend that the term should be interpreted in a strict linguistic sense. Probably, for this reason members of the OECD Committee who introduced the term did not define it. Further, a note on a discussion of the committee before the insertion of the term shows that even the United Kingdom delegation, which proposed the introduction of the term, envisaged it as an anti-avoidance provision of a general nature. The note states: ${ }^{572}$

The Delegate for the United Kingdom thought that ["beneficial owner"] should be inserted in the Convention itself, not necessarily in Articles 10, 11 and 12 , but possibly as a general provision in a separate Article.

It follows that, when applying provisions containing the beneficial ownership clause, courts should examine whether the person who received treaty benefits is the person who ought to be receiving them, rather than deciding whether a particular category of recipient is the beneficial owner.

The insertion of the term and its linguistic variations has obscured the sense in which courts should interpret

Royalties Respectively, and of the Commentary thereon" FC/WP27 (70)2, 4 November 1970, at 2. OECD Committee on Fiscal Affairs "Commentary on Article 10 concerning the Taxation of Dividends" (OECD, Paris, 2010) in OECD Committee on Fiscal Affairs Model Tax Convention on Income and on Capital (OECD, Paris, 2010) 187 at para 12. OECD Committee on Fiscal Affairs "Commentary on Article 11 concerning the Taxation of Interest" (OECD, Paris, 2010) in OECD Committee on Fiscal Affairs Model Tax Convention on Income and on Capital (OECD, Paris, 2010) 211 at para 9. OECD Committee on Fiscal Affairs "Commentary on Article 12 concerning the Taxation of Royalties" (OECD, Paris, 2010) in OECD Committee on Fiscal Affairs Model Tax Convention on Income and on Capital (OECD, Paris, 2010) 220 at para 4.

572 OECD Committee on Fiscal Affairs "Note on the discussion of the first Report of Working Party no 27 of the Fiscal Committee on Interest and Royalties during the 31 st Session of the Fiscal Committee Held from 10th to 13th June, 1969" DAF/FC/69.10, 4 July 1969, at 6 $<$ www.taxtreatieshistory.org $>$. 
and apply the treaty provisions. They ask whether a recipient is the beneficial owner, rather than whether a person who receives treaty benefits ought to receive them. Although from a substantive point of view these questions are essentially similar, courts generally make them two separate questions. They begin by defining the term "beneficial owner". They interpret the term as if it were from a statute. That is, they tend to adopt a formal legalistic reasoning, which is also the underlying feature of surrogate tests. Most of the time, courts' conclusions do not follow their reasoning. The Hoge Raad adopted this approach in the Royal Dutch Shell case. ${ }^{573}$ This case concerned Article 10(2) of the Netherlands-United Kingdom double tax treaty of 7 November $1980,{ }^{574}$ which used the term "beneficially owned".

As discussed in section 5.12, in Royal Dutch Shell, a holding company in Luxembourg sold dividend coupons of certain shares in Royal Dutch Shell to a stockbroker in the United Kingdom. The transaction occurred after Royal Dutch Shell declared dividends, but before it distributed them. The Luxembourg company designed the arrangement because it was covered by the 1929 holding company regime, ${ }^{575}$ which denied the company a withholding tax reduction under the NetherlandsLuxembourg double tax treaty of $1968 .{ }^{576}$ The stockbroker

${ }^{573}$ Royal Dutch Shell (6 April 1994) Case no 28 638, BNB 1994/217 (the Hoge Raad, the Netherlands).

${ }^{574}$ Convention for the Prevention of Fiscal Evasion with respect to Taxes on Income and Capital Gains, the Netherlands-United Kingdom (07 November 1980), art 10(2).

575 Loi du juillet 1929 sue le regime fiscal des societies de participations financiers 1929 (Luxembourg).

576 Convention for the Avoidance of Double Taxation and the Prevention of Fiscal Evasion with respect to Taxes on Income and Fortune, the Netherlands-Luxembourg (8 May 1968, enter into force 20 October 1969), art 10(2)(b). 
company cashed the coupons and requested a partial refund of the Dutch withholding tax on the dividend payment.

The Hoge Raad defined "beneficial owner" in terms of the presence of dominion. It found the stockbroker had dominion over the dividend payment. It, therefore, regarded the stockbroker as the beneficial owner. The reasoning does not make sense because the court tested the stockbroker company against an attribute that the company had by definition. Moreover, the simple fact that a company has dominion over passive income does not necessarily show that its interposition does not contradict the purpose of a double tax treaty to limit tax benefits to residents of contracting states. The analysis in section 5.13 shows that there are convincing reasons for considering the stockbroker company to be a conduit.

In contrast to its reasoning in Y-group $1990,{ }^{577}$ the Hoge Raad in Royal Dutch Shell did not interpret Article 10 of the treaty in the manner of a general anti-avoidance rule or judicial anti-avoidance doctrines. It began by interpreting the term "beneficially owned" in a strict linguistic sense and did not regard the term as a call for a substantive analysis.

\section{9. "Reasons for existence": an alternative approach} "Reasons for existence" seems to be a better approach for deciding conduit company cases than surrogate tests. Its adoption for applying the meaning of the word "beneficial" to conduit companies can be justified logically. Lord Denning's logic in adopting the predication

\footnotetext{
${ }^{577}$ Y-group 1990 (28 June 1989) Case no 25 451, BNB 1990/45 (the
} Hoge Raad, the Netherlands). 
test $^{578}$ supports this approach. An analogy can be drawn between the predication test and the "reasons for existence" approach.

The "reasons for existence" approach involves an examination of an arrangement in its entirety with an objective of determining reasons for the existence of an interposed company in a specific corporate structure. This objective allows the approach to work both ways. That is, on one hand, courts can refuse treaty benefits if they find no practical reason for the existence of the interposed company in a corporate structure, other than to obtain source state withholding tax reduction. On the other hand, courts can reasonably allow treaty benefits, if they find significant reasons for its existence in a corporate structure other than to minimise the source state withholding tax.

By contrast when applying the surrogate tests, courts examine a particular aspect of an arrangement. Although the surrogate tests address questions of fact, courts treat them as rules of law. The surrogate tests, therefore, tend to function as one-way tests and result in inconsistent decisions. For example, courts consider that a causal relationship exists between substantive business activity and beneficial ownership. The absence of business activity indicates that the interposition of a company lacked substance; the simple presence of business activity, however, does not necessarily show that a company was not interposed for improper use of a convention.

The ideal solution is to replace the term "beneficial owner" with another in the context of conduit company cases; however, until it is replaced, the deciding authorities may interpret and apply the word "beneficial"

${ }^{578}$ L J Newton v Federal Commissioner of Taxation (1958) 98 CLR 1 (Privy Council, Australia). 
to conduit company cases by using the "reasons for existence" approach. Some improvements in the official commentary on Articles 10, 11 and 12 of the OECD Model Convention may assist deciding authorities in adopting the approach.

\title{
7.10. Beneficial ownership is not an additional requirement
}

It is clear from the foregoing analysis that the purpose of the term "beneficial owner" was to emphasise an existing policy. The debate surrounding the definition of "beneficial owner", however, does not take into account the policy of the OECD Model Convention. The debate is essentially legalistic. It tends to interpret the term as if the term were in a statute. A reason for misguided attempts to define "beneficial owner" is that the language of the official commentary is confusing.

According to the official commentary on Articles 10 and 11 of the OECD Model Convention: ${ }^{579}$

\begin{abstract}
The requirement of beneficial ownership was introduced [to] paragraph $2 \ldots$ to clarify the meaning of the words "paid ... to a resident" as they are used in paragraph 1 of the Article. It makes plain that the State of source is not obliged to give up taxing rights over dividend income merely because that income was immediately received by a resident of a State with which the State of source had concluded a convention. The term "beneficial owner" is not used in a narrow technical sense, rather, it should be understood in its context and in light of the object and purposes of the Convention, including avoiding double taxation and the prevention of fiscal evasion and avoidance.
\end{abstract}

The commentary on Article 12 is similar: ${ }^{580}$

579 OECD Committee on Fiscal Affairs "Commentary on Article 10 concerning the Taxation of Dividends" (OECD, Paris, 2010) in OECD Committee on Fiscal Affairs Model Tax Convention on Income and on Capital (OECD, Paris, 2010) 187 at para 12. OECD Committee on Fiscal Affairs "Commentary on Article 11 concerning the Taxation of Interest" (OECD, Paris, 2010) in OECD Committee on Fiscal Affairs Model Tax Convention on Income and on Capital (OECD, Paris, 2010) 211 at para 9 (emphasis added). 
The requirement of beneficial ownership was introduced [to] paragraph 1 of Article 12 to clarify how the Article applies in relation to payments made to intermediaries. It makes plain that the State of source is not obliged to give up taxing rights over royalty income merely because that income was immediately received by a resident of a State with which the State of source had concluded a convention. The term "beneficial owner" is not used in a narrow technical sense, rather, it should be understood in its context and in light of the object and purposes of the Convention, including avoiding double taxation and the prevention of fiscal evasion and avoidance.

The words "it makes plain" in the second sentence of both extracts suggest that the term "beneficial owner" embodies the object and purpose of the OECD Model Convention. Beneficial ownership is the same as substantive economic ownership. The third sentence implies that an enquiry into the meaning of the term should begin with a consideration of the purpose of limiting treaty benefits.

The first sentence of each of these extracts, however, is confusing. Each states that the OECD Committee on Fiscal Affairs introduced the requirement of beneficial ownership to the provisions, and therefore, implies that "beneficial ownership" is an additional requirement, which did not exist before the insertion of the term. The phrase "requirement of beneficial ownership was introduced" overshadows the effect of the words "it makes plain". It is possible that, because of this linguistic confusion, the purpose of restricting treaty benefits to residents of contracting states is often not considered before determining the meaning of "beneficial owner".

The committee did not introduce the requirement of beneficial ownership, or of substantive economic

580 OECD Committee on Fiscal Affairs "Commentary on Article 12 concerning the Taxation of Royalties" (OECD, Paris, 2010) in OECD Committee on Fiscal Affairs Model Tax Convention on Income and on Capital (OECD, Paris, 2010) 220 at para 4 (emphasis added). 
ownership. The requirement is inherent. That is, because contacting states enter into double taxation treaties intending to provide relief from double taxation only to their residents, decision-making authorities should interpret provisions concerning the reduction of source state's withholding tax regardless of whether those provisions use the term "beneficial owner". ${ }^{581}$ In $\operatorname{Re} V$ $S A,{ }^{582}$ the Swiss Federal Commission of Appeal in Tax Matters clarified that the requirement beneficial ownership is implicit in double taxation conventions and does not require an express reference. ${ }^{583}$ Nevertheless, as discussed in section 2.8, the committee introduced the term "beneficial owner" probably because some courts tend to interpret tax treaties in a strict legalistic manner. It may help to replace the words "the requirement of beneficial ownership" 584 with "the term 'beneficial owner".

Further, the last sentence of both extracts suggests that the term "beneficial owner" is not used in a narrow technical sense and that the term should be understood in its context and in th elight of the object and purposes of the Convention. While the sentence attempts to clarify that the term "beneficial owner" should not be interpreted in a strict linguistic sense, it does so implicitly. The OECD

\footnotetext{
${ }^{581}$ See Klaus Vogel Double Taxation Conventions: a Commentary to the OECD-, UN-, US-Model Conventions for the Avoidance of Double Taxation of Income and Capital with particular reference to German Treaty Practice (Kluwer, Deventer, 1990) at 459. See David A Ward "Principles to be Applied in Interpreting Tax Treaties" (1977) 25 Canadian Tax Journal 263 at 265.

${ }^{582}$ Re V SA 4 ITLR 191(The Federal Commission of Appeal in Tax Matters, Switzerland).

${ }^{583} \mathrm{Ibid}$, at 208.

${ }^{584}$ Commentary on Article 10, above n 579, at para 12. Commentary on Article 11, above n 579, at para 9. Commentary on Article 12, above $\mathrm{n} 580$, at para 4 .
} 
Committee on Fiscal Affairs may consider adding the following words in order to make its intention explicit:

The term "beneficial owner" is intended to emphasise the policy of the convention, not to describe a relevant linguistic or legal concept. The term emphasises that it is not enough to be formally a resident of a Contracting State. In order to be entitled to a reduction in the source State withholding tax, the resident of the other Contracting State must own [dividends, interest or royalties] in an economic sense. The emphasis is on the ownership, not on the business activity of an immediate recipient of income.

\subsection{The "activity provision"}

As discussed in section 4.2, the Conduit Companies Report $^{585}$ and the official commentary on Article 1 of the OECD Model Convention ${ }^{586}$ recommend safeguard provisions that limit treaty benefits to residents of the contracting states in conduit company cases. Most of these provisions apply the concept of "substantial interest". Although they do not define the concept, they seem to use it in the sense of substantive economic ownership, a concept that the term "beneficial ownership" also represents. Because these provisions have a broad scope, the Conduit Companies Report and the official commentary recommend that treaty negotiators should apply these provisions together with the bona fide provisions, ${ }^{587}$ in order to ensure that treaty benefits are granted only in bona fide cases.

${ }^{585}$ OECD Committee on Fiscal Affairs "Double Taxation Conventions and the Use of Conduit companies" in OECD Committee on Fiscal Affairs International Tax Avoidance and Evasion: Four Related Studies, Issues in international Taxation No 1 (OECD, Paris, 1987) 87, at para 42 (ii).

586 OECD Committee on Fiscal Affairs "Commentary on Article 1 concerning the Persons Covered by the Convention" in OECD Committee on Fiscal Affairs Model Tax Convention on Income and on Capital (OECD, Paris, 2010) 62, at para 13.

${ }^{587}$ Commentary on Article 1 of the OECD Model Convention, above $n$ 586 , at para 18 . 
The "activity provision", which is one of the bona fide provisions, uses the criterion of substantive business activity to differentiate bona fide cases from conduit company cases. It states: $:^{58}$

[The safeguard provisions] shall not apply where the company is engaged in substantive business operations in the Contracting State of which it is a resident and the relief from taxation claimed from the other Contracting State is with respect to income that is connected with such operations.

The language of the "activity provision" suggests that an interposed company shall not be considered to be a conduit if that company is involved in substantive business activity. When the "activity provision" operates in conjunction with the safeguard provisions that use the concept of substantive economic ownership, it implies that there exists a cause and effect relationship between substantive business activity and substantive economic ownership.

Chapter 4 explained that substantive business activity was originally a test for deciding cases involving foreign base companies. A possible reason for its transposition from base company cases to conduit company cases is that the two types of cases appear to be similar in terms of company structures and income accrual to the taxpayer in the resident country. Notwithstanding the apparent similarities, certain crucial differences make it inappropriate to apply the substantive business activity test to conduit company cases.

The function of a base company is to reduce income tax in the country of a taxpayer's residence by sheltering the taxpayer's foreign source income that would otherwise accrue directly to it. Courts apply general anti-avoidance

\footnotetext{
${ }^{588}$ Commentary on Article 1 of the OECD Model Convention, above
} n586, at para 19(b). 
rules or judicial anti-avoidance doctrines to deal with base companies cases. Some countries have also enacted controlled foreign company legislation. Generally, courts and legislation attribute income of a base company to a taxpayer if they find that the company receives passive investment income that arises from capital that is readily movable from country to country. They do not attribute a base company's income to the taxpayer if they find that the company is pursuing actively and legitimately some income producing undertaking. That is, the decision in base company cases largely depends upon the distinction between active and passive income. Courts apply the substantive business activity test for determining the nature of a base company's income.

It is inappropriate, however, to apply the substantive business activity test to conduit company cases relying upon the reasoning of base company cases. A conduit company case does not concern the nature of income. Articles 10, 11 and 12 involve passive income.

The relevance of the substantive business activity criterion in conduit company cases cannot be completely ruled out. The fact that a recipient company is not engaged in a business activity shows that its interposition lacks substance. However, it should not be inferred that the simple presence of business activity necessarily makes a recipient company entitled to treaty benefits. An interposed company that is involved in a substantive business activity may still be a conduit. That is, unlike a base company case, a conduit company case cannot be decided on the basis of business activity.

Nevertheless, the effect of the "business activity" provision is as if business activity were a decisive test in conduit company cases. It may help if the "activity 
provision" is not included as a bona fide provision in the context of conduit companies.

\subsection{Reference to paragraph 14(b) of the Conduit Companies Report}

Chapter 5 explained that courts use dominion, an incident of ownership, for determining whether a person acts in the capacity of a "nominee or agent". As discussed in section 5.4, paragraph 14(b) of the Conduit Companies Report ${ }^{589}$ applies the dominion test to conduit company cases on the basis of apparent similarities between the role of a "nominee or agent" and the function of a conduit company.

Paragraph 14(b) refers to the commentary on Articles 10, 11 and 12 of the OECD Model Convention of 1977, which used a "nominee or agent" as an example for explaining the function of conduit companies. The commentary presented the example in a manner that implied that cases concerning nominees or agents involve a question of whether they can be allowed treaty benefits.

Although the attribute of passing income on to a third party makes nominees or agents appear similar to conduit companies, there is a crucial difference. Unlike conduit companies, nominees or agents are obliged to pass on income as it accrues to a third party.

When claiming a tax reduction in source state taxation, conduit companies tend to argue that they are under no obligation in property law to pass on passive income to a third party. That is, they tend to rely on the fact that they have, by definition, dominion over passive income. For

589 OECD Committee on Fiscal Affairs "Double Taxation Conventions and the Use of Conduit Companies" in OECD Committee on Fiscal Affairs International Tax Avoidance and Evasion: Four Related Studies, Issues in International Taxation No 1 (OECD, Paris, 1987) 87 at para $14(b)$. 
this reason, courts should examine the substance of such cases and determine whether the interposition of the recipient company is bona fide. Therefore, it makes sense to ask the question whether an interposed company can be allowed to use the limitation on the source state's right to tax in order to reduce the effect of the domestic tax law of the source state. By contrast, it is illogical to ask this question in cases in which the interposed entity acts as a "nominee or agent" because such an entity is under an obligation in property law to pass on passive income.

The official commentary on Articles 10, 11 and 12, as it stands after 2003, appears to have overcome this shortcoming to a large extent. It states: ${ }^{590}$

Where an item of income is received by a resident of a Contracting State acting in the capacity of agent or nominee it would be inconsistent with the object and purpose of the Convention for the State of source to grant relief or exemption merely on account of the status of the immediate recipient of the income as a resident of the other Contracting State. The immediate recipient of the income in this situation qualifies as a resident but no potential double taxation arises as a consequence of that status since the recipient is not treated as the owner of the income for tax purposes in the State of residence. It would be equally inconsistent with the object and purpose of the Convention for the State of source to grant relief or exemption where a resident of a Contracting State, otherwise than through an agency or nominee relationship, simply acts as a conduit for another person who in fact receives the benefit of the income concerned. For these reasons, the report from the Committee on Fiscal Affairs entitled "Double Taxation Conventions and the Use of Conduit Companies" concludes that a conduit company cannot normally be regarded as the beneficial owner if, though the formal owner, it has, as a practical matter, very

590 OECD Committee on Fiscal Affairs "Commentary on Article 10 concerning the Taxation of Dividends" (OECD, Paris, 2003) in OECD Committee on Fiscal Affairs Model Tax Convention on Income and on Capital (OECD, Paris, 2003) 145 at para 12.1. OECD Committee on Fiscal Affairs "Commentary on Article 11 concerning the Taxation of Interest" (OECD, Paris, 2003) in OECD Committee on Fiscal Affairs Model Tax Convention on Income and on Capital (OECD, Paris, 2003) 162 at para 8.1. OECD Committee on Fiscal Affairs "Commentary on Article 12 concerning the Taxation of Royalties" (OECD, Paris, 2003) in OECD Committee on Fiscal Affairs Model Tax Convention on Income and on Capital (OECD, Paris, 2003) 173 at para 4.1. 
narrow powers which render it, in relation to the income concerned, a mere fiduciary or administrator acting on account of the interested parties.

It is clear that the commentary does not consider nominees or agents to qualify for treaty benefits on any criterion. However, the problem is that it still refers to the conclusion that the Conduit Companies Report draws in paragraph 14(b). As discussed in section 5.4, paragraph 14(b) in turn relies on the official commentary on Articles 10, 11 and 12 of the OECD Model Convention of 1977.

Because courts and commentators widely refer to paragraph 14(b) for determining the meaning of the term "beneficial owner", it is possible that courts may ignore the clarification with respect to nominees or agents. The approach adopted by the Tax Court of Canada in Prévost Car Inc v Her Majesty the Queen ${ }^{591}$ illustrates the point. As discussed in section 5.15, the court transposed the dominion test from cases involving nominees and agents to conduit company cases. It acknowledged that the commentary on Article 10(2) of the OECD Model Convention of 1977 was amended in 2003; but, the reference to the conclusion in paragraph 14(b) confused the court. That is, instead of differentiating the role of a "nominee or agent" from the function of a conduit company, the court compared them. As a result, the court effectively relied on the official commentary of Article 10 of the OECD Model Convention of 1977.

Because paragraph 14(b) of the Conduit Companies Report is based on the shortcomings of the official commentary on the OECD Model Convention of 1977, the amended official commentary would be more effective if it did not refer to paragraph $14(b)$.

${ }^{591}$ Prévost Car Inc v Her Majesty the Queen (2008) TCC 231, at para 31. 


\subsection{The OECD's discussion draft on the clarification of the meaning of the term "beneficial owner"}

In April 2011, the OECD Committee on Fiscal Affairs published a discussion draft on the clarification of the meaning of the term "beneficial owner" in the OECD Model Convention. ${ }^{592}$ The draft proposed changes to the commentary on Articles 10, 11 and 12. It is encouraging that some of these changes are in line with the arguments that this thesis presents.

For instance, the proposed paragraphs 12.6, 10.4 and 4.5 to the commentary on Articles 10, 11 and 12 respectively support the hypothesis that logically and in an economic sense the concept of beneficial ownership is not capable of being applied to companies. The paragraphs begin by referring to the term "beneficial owner" as used by the 2001 OECD's report entitled "Behind the Corporate Veil: Using Corporate Entities for Illicit Purposes", which considers a beneficial owner to be a "natural person". 593 The report concerns issues arising out of the use of corporate entities for illicit purposes, such as money laundering, bribery, hiding and shielding assets from creditors, illicit tax practices, self-dealing, market fraud and circumvention of disclosure requirements. The draft considers the definition accorded by the report does not apply to the OECD Model Convention for two reasons. First, the report defines beneficial owner in the context of "anonymity-enhancing instruments", 594 such as bearer shares, nominee shareholders, nominee directors,

592 OECD Committee on Fiscal Affairs Clarification of the Meaning of "Beneficial Owner" in the OECD Model Tax Convention Discussion Draft (OECD, Paris, 2011).

${ }^{593}$ OECD Committee on Fiscal Affairs Behind the Corporate Veil Using Corporate Entities for Illicit Purposes (OECD, Paris, 2001) at 14.

${ }^{594}$ Ibid at 10. 
"corporate" directors, flee clauses, and letters of wishes.

Second, paragraphs 12.6 and 10.4 explain: ${ }^{595}$

Indeed, that meaning, which refers to natural persons (i.e. individuals), cannot be reconciled with the express wording of subparagraph [2(a)], which refers to the situation where a company is the beneficial owner of a dividend. Since, in the context of Article 10, the term beneficial owner is intended to address difficulties arising from the use of the word "paid" in relation to dividends, it would be inappropriate to consider a meaning developed in order to refer to the individuals who exercise "ultimate effective control over a legal person or arrangement".

Paragraph 4.5 is similar: ${ }^{596}$

Indeed, that meaning, which refers to natural persons (i.e. individuals), cannot be reconciled with the express wording of subparagraph 2 a) of Article 10, which refers to the situation where a company is the beneficial owner of a dividend. Since the term beneficial owner was intended to address difficulties arising from the use of the word "paid", which is found in paragraph 1 of Articles 10 and 11 and was similarly used in paragraph 1 of Article 12 of the 1977 Model Double Taxation Convention, it would be inappropriate to consider a meaning developed in order to refer to the individuals who exercise "ultimate effective control over a legal person or arrangement"

The proposed commentary clearly supports the hypothesis of this thesis. Moreover, it clarifies that the OECD Committee intends to use the term to address difficulties arising from the use of the word "paid". An apparent difficulty is that courts tend to interpret treaty provisions of double tax treaties in a strictly literal sense. The problem of interpreting the word "paid" literally is that tax benefits will effectively be granted to persons to whom a double tax treaty is not intended to apply. Thus, the commentary supports the point that the term "beneficial owner" indicates that courts should adopt a substantive point of view. In other words, the term enforces the tax treaty policy of limiting treaty benefits.

595 The discussion draft on the clarification of the meaning of "beneficial owner", above n 592, at 4 and 7.

${ }^{596}$ Ibid, at 9. 
The foregoing paragraphs help to understand paragraphs $12.5,10.3$ and 4.4 of the proposed commentary on Articles 10, 11 and 12 of the OECD Model Convention respectively. Paragraph 12.5 state: ${ }^{597}$

The fact that the recipient of royalties is considered to be the beneficial owner of these royalties does not mean, however, that the provisions of paragraph 2 must automatically be applied. These provisions should not be granted in cases of abuse ... As explained in the section on "Improper use of the Convention" in the Commentary on Article 1, there are many ways of addressing [conduit companies] and, more generally, treaty shopping situations. These include specific treaty anti-abuse provisions, general anti-abuse rules and substance-over-form or economic substance approaches. Whilst the concept of "beneficial owner" deals with some forms of tax avoidance (i.e. those involving the interposition of a recipient who is obliged to pass the royalties to someone else), it does not deal with other cases of treaty shopping and must not, therefore, be considered as restricting in any way the application of other approaches to addressing such cases.

Paragraphs 10.3 and 4.4 of the proposed commentary are worded similarly. ${ }^{598}$ As with the Swiss Federal Court in A Holding ApS v Federal Tax Administration, ${ }^{599}$ the proposed commentary differentiates the meaning of beneficial ownership for legal purposes from that for the purposes of double tax treaties. It clarifies that for legal purposes a beneficial owner is not necessarily entitled to treaty benefits. In other words, beneficial ownership operates as an anti-avoidance test, not as a test of ownership. This thesis makes exactly the same point in section 7.7 .

The proposed commentary, however, does not consider certain shortcomings of the existing commentary, which this thesis highlights. For instance, paragraphs 12, 9 and 4

597 The discussion draft on the clarification of the meaning of "beneficial owner", above n 592, at 4.

${ }^{598}$ Ibid, at 6 and 9.

${ }^{599}$ A Holding ApS v Federal Tax Administration (2005) 8 ITLR 536 (The Federal Court, Switzerland) at 559. 
of the commentary on Articles 10,11 and 12 respectively still infers that the Conduit Companies Report draws on paragraph 14(b). As discussed in section 7.12, paragraph 14(b) is based on the official commentary of 1977, which implied that cases concerning nominees or agents require determination of whether the intermediary is a beneficial owner. Paragraphs 12.4, 10.2 and 4.3 of the proposed commentary on the Articles 10, 11 and 12 respectively add to the confusion. They state: ${ }^{600}$

In these various examples (agent, nominee, conduit company acting as a fiduciary or administrator), the recipient of the [passive income] is not the "beneficial owner" because that recipient does not have the full right to use and enjoy the [income] that it receives and this [income] is not its own; the powers of that recipient over that [income] are indeed constrained in that the recipient is obliged (because of a contractual, fiduciary or other duty) to pass the payment received to another person.

The extract appears to cite agents and nominees as examples of conduits. As discussed in section 5.11, presenting agents and nominees as conduits may imply that the absence of the obligation to pass on income necessarily means that an interposed company is entitled to treaty benefits.

This thesis does not analyse the OECD discussion draft in further detail because the draft was published shortly before the submission of this thesis. Further analysis of the draft is currently in process.

\subsection{Future implications}

The objective of the thesis is to analyse the problem of interpreting the term "beneficial owner" and applying it to conduit company cases. Several reasons have driven the thesis to analyse the problem. Scholars have debated the

600 The discussion draft on the clarification of the meaning of "beneficial owner", above n 592, at 4, 6 and 8. 
meaning of the term, since its introduction in the OECD Model Convention of 1977. Further, courts have interpreted and applied the term inconsistently to relatively similar sets of facts and reached different conclusions. The problem also has significant political implications. It affects national tax policies of several developed and developing countries. Moreover, the economic impact of the problem is evident from the amount of revenue at stake.

A consensus exists on the generic policy of double tax treaties, which is to limit tax benefits to residents of contracting states. However, it is difficult to apply the policy: the problem of dealing with conduit companies is not an example of bad policy, rather it is an example of confused execution

This thesis is an effort to help courts, tax authorities, and scholars understand the existing policy better. It clarifies confusion over the execution of existing policy. The thesis highlights subtle differences in the legal reasoning, which can affect the outcome of conduit company cases. It intends to make courts aware of ramifications of their reasoning.

With the help of case analysis, the thesis has shown that courts can decide conduit company cases more convincingly if they apply the beneficial ownership test as if it were a general anti-avoidance rule. It is hoped that this approach would assist courts and tax authorities to interpret and apply the test in more logically and consistently. 


\section{Appendix}

\section{Translations}

This thesis involves a comparative analysis of cases of different jurisdictions. Until recently, conducting such a study was extremely difficult not only for students, but also for university teachers. However, the availability of electronic translation services, such as Google translator have greatly helped the process of translating judgments in other languages.

Although translations from Google translator are rough, it is possible to improve them by translating small groups of words rather than the entire text. For example, quoting the Bundesfinanzhof in the Group 2005 case, section 4.24 argued that the court equated the presence of "economic or other valid reasons" with "business purpose". The original word that the Bundesfinanzhof used for the words "business purpose" was "Unternehmenszwecke", which Google translator translates as "corporate purposes". When translated alone, the word "unternehmen" can mean “enterprise", "business" and "undertaking". In the context of base company cases and the substantive business activity test, "Unternehmenszwecke" may reasonably be translated as "business purpose".

In order to ensure the accuracy of the translations the author consulted Dutch, French and German native speakers who helped to refine the translations further. The author is indebted to his supervisor, Professor Kevin Holmes, for his help and guidance as well as his good command of Dutch.

In some cases, legal scholars have already translated certain paragraphs of important judgments. For instance, Stef van Weeghel translated certain paragraphs of $W$ family 1 and $W$-family 2. His translations helped the 
understanding of the reasoning adopted by lower courts and the Hoge Raad. In the light of these inferences, the author translated other paragraphs of the cases and found that the approach adopted by Dutch courts corresponded to the end result test adopted by the United States courts for implementing the step transaction doctrine.

Google translator, contributions from colleagues and supervisors, and certain extracts translated by legal scholars were extremely helpful in capturing the essence of the foreign language cases. The kind of comparative analysis undertaken in this thesis would not have been possible otherwise. 


\section{References}

\section{Books}

Philip Baker Double Taxation Conventions and International Tax Law (2 ed, Sweet and Maxwell, London, 1994).

Lawrence C Becker Property Rights: Philosophical Foundations (Routledge and Kegan Paul, London, 1977).

William Bowstead and F M B Reynolds Bowstead and Reynolds on Agency (18th ed, Sweet \& Maxwell, London, 2006).

Marvin Chirelstein Federal Income Taxation A Law Student's Guide to the Leading Cases and Concepts (9th ed, Foundation Press, New York, 2002).

Charl P du Toit Beneficial Ownership of Royalties in Bilateral Tax Treaties (IBFD, Amsterdam, 1999).

G H L Fridman Law of Agency (2nd ed, Butterworths, London, 1966).

Lon L Fuller Legal Fictions (Stanford University Press, Stanford, 1967).

Francis Gore-Browne, A J Boyle and Richard Sykes GoreBrowne on Companies (44 ed, vol 1, Jordans, Bristol, 1986).

Peter A Harris Corporate Shareholder Income Taxation and Allocating Taxing Rights between Countries (IBFD, Amsterdam, 1996).

Kevin Holmes The Concept of Income: A Multidisciplinary Analysis (IBFD, Amsterdam, 2000).

RLH IJzerman Het leerstuk van de wetsontduiking in het belastingrecht (Kluwer, Deventer, 1991).

International Fiscal Association Congress International Tax Treatment of Common Law Trusts: Proceedings of a Seminar held in New York in 1986 during the 40th Congress of the International Fiscal Association (Kluwer Law and Taxation Publishers, New York, 1998).

John Prebble "Ectopia, Formalism and Anti-avoidance Rules in Income Tax Law" in Werner Krawietz, Neil MacCormick, Georg Henrik von Wright (eds) Prescriptive formality and normative rationality in modern legal systems: festschrift for Robert S. Summers (Duncker \& Humblot, Berlin, 1994) 367.

Shadtai Rosenne (ed) League of Nations Committee of Experts for the Progressive Codification of International Law [1925-1928] (Oceana Publications, New York, 1972). 
John William Salmond and P J Fitzgerald Salmond on Jurisprudence (12 ed, Sweet and Maxwell, London, 1966)

Daniel Sandler Tax Treaties and Controlled Foreign Company Legislation: Pushing the Boundaries (Kluwer Law International, The Hague, 1998).

Stef van Weeghel The Improper Use of Tax Treaties: with Particular Reference to the Netherlands and the United States (Kluwer, London, 1998).

Klaus Vogel Double Taxation Conventions: a Commentary to the OECD-, UN-, US-Model Conventions for the Avoidance of Double Taxation of Income and Capital with particular reference to German Treaty Practice (Kluwer, Deventer, 1990).

Klaus Vogel The OECD Model Convention, 1998 and Beyond: the Concept of Beneficial Ownership in Tax Treaties: Proceedings of a Seminar held in London in 1998 during the 52nd Congress of the International Fiscal Association (Kluwer Law International, London, 2000).

\section{Articles}

Rijkele Betten "Abuse of Law: Treaty Shopping through the Use of Base companies" (1986) ET 323.

Herman Born "Beneficial Ownership: Decision of the Netherlands Supreme Court of 6 April 1994" (1994) ET 469.

F E Dowrick "The Relationship of Principal and Agent" (1954) 17 MLR 24.

Wim Eynatten and others "The Concept of 'Beneficial Ownership' under Belgian Tax Law: Legal Interpretation is Maintained" (2003) 31 Intertax 523.

Rolf Füger and Norbert Rieger "German Anti-Avoidance Rules and Tax Planning of Non-Resident Taxpayers" (2000) 54 Bulletin of International Bureau of Fiscal Documentation 434.

Wilhelm Haarmann and Christoph Knödler "German Supreme Tax Court Limits the Scope of the German AntiTreaty Shopping Rule and Redefines Substance Requirement for Foreign Companies (2006) 34 Intertax 260.

John F Avery Jones and others "The Origin of Concepts and Expressions Used in the OECD Model and their Adoption by States" (2006) 60 Bulletin for International Taxation 220.

John F. Avery Jones and others "The Treatment of Trusts under the OECD Model Convention" (1989) ET 379. 
Yoram Keinan "Rethinking the Role of the Judicial Step Transaction Principle and a Proposal for Codification" (2007) 22 Akron Tax J 45.

ECCM Kemmerem "De Hoge Raad heft de dividendbelasting afgeschaft" in Weekblad voor fiscal recht, No. 6141, 1995.

Richard A Musgrave "The Carter Commission Report" (1968) 1 the Canadian Journal of Economics 159.

J David B Oliver and others "Beneficial Ownership" (2000) 54 Bulletin for International Taxation 310.

Hans Pijl "The Definition of "Beneficial Ownership" under Dutch Law" (2000) 54 Bulletin for International Taxation 256.

John Prebble "Can Income Tax Law be Simplified?" (1996) 2 NZ Journal of Taxation Law and Policy 187.

John Prebble "Ectopia, Tax Law, and International Taxation" (1997) BTR 383.

John Prebble "Fictions of Income Tax Law" (2002) Working Paper Series No 7 Centre for Accounting, Governance and Taxation Research, Victoria University Wellington.

John Prebble "Trust and Double Taxation Agreements" (2004) 2 eJournal of Tax Research 192.

Victor Thuronyi “The Concept of Income” (1990) 46 Tax Law Review 45.

David A Ward "Principles to be Applied in Interpreting Tax Treaties" (1977) 25 Canadian Tax Journal 263.

"Dutch Holding Company not Always Entitled to a Full Refund of the Swiss Tax Withheld on Dividends from a Swiss Subsidiary" (1986) 26 ET 57. 



\section{List of cases}

\section{Australia}

L J Newton v Federal Commissioner of Taxation (1958) 98 CLR 1.

Cecil Bros Pty Ltd v Federal Commissioner of Taxation (1964) 111 CLR 430 (FC).

South Sydney District Rugby League Football Club Ltd v News Ltd and Others (2000) 177 ALR 611.

\section{Austria}

$N A G v$ Regional Tax Officer for Upper Austria (2000) 2 ITLR 884 (The Supreme Administrative Court, Austria).

\section{Canada}

Royal Securities Corp Ltd v Montreal Trust Co (1966) 59 DLR (2d) 666.

Gladden Estate v Minister of National Revenue (1985) 1 CTC 163.

Kenneth A Williams v The Queen (2005) DTC 1228 (Tax Court of Canada, Canada).

MIL (Investment) SA v Canada (2006) TCC 460.

MIL (Investment) SA v Canada 2007 FCA 236.

Prévost Car Inc v Her Majesty the Queen (2008) TCC 231.

Her Majesty the Queen v Prévost Car Inc 2009 FCA 57.

\section{France}

Ministre de l'Economie, des Finances et de l'Industrie $v$ Société Bank of Scotland (2006) 9 ITLR 683 (Conseil d'État, France).

\section{Germany}

The decision of the Bundesfinanzhof of 5 March 1986, IR 2001/82, para 496.

Re a Corporation (2002) 5 ITLR 589 (The Bundesfinanzhof, Germany).

G-group 2005 (31 May 2005) IR 74, 88/04 (The Bundesfinanzhof, Germany).

\section{India}

In Re XYZ (1996) 220 ITR 377 (AAR) (The Authority for Advance Rulings, India). 


\section{The Netherlands}

Y-group 1990, Case no 25 451, BNB 1990/45 (the Hoge Raad, the Netherlands).

Royal Dutch Shell (6 April 1994) Case no 28 638, BNB 1994/217 (the Hoge Raad, the Netherlands).

$W$-family 1 (18 May 1994) Case no 28 293, BNB 1994/252 (the Hoge Raad, the Netherlands)

$W$-family 2 (18 May 1994) Case no 28 296, BNB 1994/253 (the Hoge Raad, the Netherlands).

\section{Switzerland}

X-group 1979 (1979) 48 Archives de droit fiscal Suisse 271 (The Federal Tax Administration, Switzerland).

Arabian-group 19841984 (1984) BGE 110 Ib 287.

Re V SA (2001) 4 ITLR 191 (The Federal Commission of Appeal in Tax Matters, Switzerland).

A Holding ApS v Federal Tax Administration (2005) 8 ITLR 536 (The Federal Court, Switzerland).

\section{The United Kingdom}

Keech $v$ Sandford (1726) EWHC Ch J76.

Irvine v Houston (1802) Paton sc App 521.

Paris v Paris (1804) 10 Ves 185.

Witts v Steere (1807) 13 Ves 363.

Salomon v A Salomon \& Co Ltd [1897] AC 22.

Baker v Archer-Shee [1927] AC 844.

Gartside v Inland Revenue Commissioners [1968] AC 553.

Wood Preservation Ltd $v$ Prior (Inspector of Taxes) [1969] All ER 364.

Ayrest (Inspector of Taxes) $v C \& K$ (Construction) Ltd [1975] 2 All ER 537.

Fothergill v Monarch Airlines Ltd [1980] AC 251.

$J$ Sainsbury Plc v O'Connor (Inspector of Taxes) (1991) STC 318.

Indofood International Finance Ltd v JP Morgan Chase Bank NA, London Branch [2006] EWCA Civ 158.

\section{The United States}

Eisner v Macomber 252 US 189 (1920).

Commissioner of Internal Revenue v Nevius 76 F2d 109 (2d Cir 1935). 
Moline Properties Inc $v$ Commissioner of Internal Revenue 319 us 436 (1943).

National Carbide Corp $v$ Commissioner of Internal Revenue 336 us 422 (1949).

Knetsch v United States 364 us 361 (1960).

Commissioner of Internal Revenue v Gordon 391 US 83 (1968).

Aiken Industries Inc v Commissioner of Internal Revenue 56 TC 925 (1971).

Redding v Commissioner of Internal Revenue $630 \mathrm{~F} \mathrm{2d}$ 1169 (1980)

Jones $v$ Commissioner of Internal Revenue $640 \mathrm{~F} 2 \mathrm{~d} 745$ (5th Cir 1981).

Roccaforte v. Commissioner of Internal Revenue 77 TC 263 (1981).

Bruce L. Schlosberg v United States of America (1981) 811 USTC (CCH) P9272.

Hospital Corporation of America $v$ Commissioner of Internal Revenue 81 TC 520 (1983).

Revenue Ruling 84-153 (1984) 2 Св 383.

Robert A Penrod v Commissioner of Internal Revenue 88 TC 1415 (1987)

Liggett Group Inc v Commissioner of Internal Revenue TC Memo 1990-18.

James A Shriver v Commissioner of Internal Revenue 899 F 2d 724 (8th Cir 1990).

Leonard Greene and Joyce Greene v United States of America 13 F 3d 577 (2d Cir 1994).

Northern Indiana Public Service Company $v$ Commissioner of Internal Revenue 105 TC 341 (1995).

SDI Netherlands BV v Commissioner of Internal Revenue 107 TC 161 (1996).

Northern Indiana Public Service Company $v$ Commissioner of Internal Revenue 115 F 3d 506 (7th Cir 1997).

Del Commercial Properties Inc $v$ Commissioner of Internal Revenue TC Memo 411 (1999).

Jean D. True v United States of America 190 F 3d 1165 (10th Cir 1999).

Del Commercial Properties Inc $v$ Commissioner of Internal Revenue 251 F 3d 210 (2001). 
Andantech LLC v Commissioner of Internal Revenue 83 TCM (CCH) 1476 (2002).

Long Term Capital Holdings $v$ United States of America 330 F Supp 2d 122 (2004).

Transcapital Leasing Assocs 1990-II LP v United States 97 AFTR 2d 2006-1916 (2006).

HIE Holdings Inc v Commissioner of Internal Revenue TC Memo 2009-130. 


\section{The OECD Documents}

\section{The OECD Model Conventions}

OECD Committee on Fiscal Affairs Model Tax Convention on Income and on Capital (OECD, Paris, 1977).

OECD Committee on Fiscal Affairs Model Tax Convention on Income and on Capital (OECD, Paris, 2010).

\section{Notes}

OECD Committee on Fiscal Affairs "Note on the Discussion of the First Report of Working Party No 27 of the Fiscal Committee on Interest and Royalties during the 31st Session of the Fiscal Committee held from 10th to 13th June, 1969" DAF/FC/69.10, 4 July 1969, $<$ www.taxtreatieshistory.org $>$.

\section{Reports}

OECD Committee on Fiscal Affairs "Preliminary Report on Suggested Amendments to Articles 11 and 12 of the Draft Convention, relating to Interest and Royalties Respectively" FC/WP27 (68) 1， 30 December 1968 $<$ www.taxtreatieshistory.org $>$.

OECD Committee on Fiscal Affairs "Tax Havens: Measures to Prevent Abuse by Taxpayers" in OECD Committee on Fiscal Affairs International Tax Avoidance and Evasion: Four Related Studies, Issues in International Taxation No 1 (OECD, Paris, 1987) 20.

OECD Committee on Fiscal Affairs "Double Taxation Conventions and the Use of Base Companies" in OECD Committee on Fiscal Affairs International Tax Avoidance and Evasion: Four Related Studies, Issues in International Taxation No 1 (OECD, Paris, 1987) 60.

OECD Committee on Fiscal Affairs "Double Taxation Conventions and the Use of Conduit Companies" in OECD Committee on Fiscal Affairs International Tax Avoidance and Evasion: Four Related Studies, Issues in International Taxation No 1 (OECD, Paris, 1987) 87.

OECD Committee on Fiscal Affairs "Triangular Cases" in OECD Committee on Fiscal Affairs Model Tax Convention: Four Related Studies, Issues in International Taxation, No 4 (OECD, Paris, 1992) 28.

OECD Committee on Fiscal Affairs International Harmful Tax Competition an Emerging Global Issue (OECD, Paris, 1998).

OECD Committee on Fiscal Affairs "Restricting the Entitlement to Treaty Benefits" in OECD Committee on 
Fiscal Affairs 2002 Reports Related to the OECD Model Tax Convention (OECD, Paris, 2003) 9.

\section{Discussion drafts}

OECD Committee on Fiscal Affairs Clarification of the Meaning of "Beneficial Owner" in the OECD Model Tax Convention: Discussion Draft (OECD, Paris, 2011). 


\section{Statutory and parliamentary references}

\section{Australia}

The Income Tax and Social Services Contribution Assessment Act 1936-1950.

\section{Belgium}

Wetboek der Inkomstenbelastingen/Code des impôts sur les revenus of 12 June 1992 (Income Tax Code).

\section{Germany}

Einkommensteuergesetz [EStG] [Income Tax Act], 16 October 1934 RGBl I at 1005, § 50d, ๆ 3.

Einkommensteuergesetz [EStG] [Income Tax Act], 16 October 1934 BGBl I at 3366 as amended by Jahressteuergesetzes [Finance Law], 13 December 2006 BGBl I at 2878, § 50d, ๆ 3.

Verrechnungssteuergesetz [VStG] [Withholding Tax Law], 13 October 1965, SR 642.21, (Switz.).

Abgabenordnung [AO] [The General Tax Code] 16 March 1976, BGBl I at 3366, as amended, § 42.

\section{India}

Income Tax Act 1961.

\section{Luxembourg}

Loi du juillet 1929 sue le regime fiscal des societies de participations financiers 1929 (Luxembourg).

\section{The Netherlands}

Dividend Tax Act of 1969.

Belastingregeling voor het Koninkrijk (28 October 1964, entered into force 12 December 1985) (The Tax Arrangement for the Kingdom of the Netherlands)

\section{The United Kingdom}

Finance Act 1954.

Finance Act of 1973.

Income and Corporation Taxes Act 1970.

\section{The United States}

Revenue Act 1916 Ch 463, 39 Stat 756 (1916), §2(a).

Internal Revenue Code 26 USC $\S 482$.

The Deficit Reduction Act 1984. 



\section{Treaties and directives}

Convention with respect to Taxes on Income and certain other Taxes, the United States-the Netherlands (29 April 1948).

Protocol to the Convention for Avoidance of Double Taxation and the Prevention of Fiscal Evasion with Respect to Taxes on Income and Property, Switzerlandthe Netherlands (12 November 1951, entered into force 22 December 1966).

Convention for Avoidance of Double Taxation and the Prevention of Fiscal Evasion with Respect to Taxes on Income, the United States-Honduras (25 June 1956, entered into force 6 February 1957, terminated on 31 December 1966).

Convention for the Avoidance of Double Taxation with respect to Taxes on Income and Capital and Various other Taxes, and for the Regulation of other Questions relating to Taxation, Germany-the Netherlands (16 June 1959, entered into force 18 September 1960).

Supplementary Convention Modifying and Supplementing the Convention with Respect to Taxes on Income and Certain other Taxes, United States-the Netherlands (30 December 1965, entered into force 8 July 1966).

Convention for the Avoidance of Double Taxation and the Prevention of Fiscal Evasion with respect to Taxes on Income and Fortune, the Netherlands-Luxembourg (8 May 1968, entered into force 20 October 1969).

Convention for the Avoidance of Double Taxation and the Prevention of Fiscal Evasion with respect to Taxes on Income, France-the United Kingdom (22 May 1968, entered into force 27 October 1969).

Vienna Convention on the Law of Treaties (23 May 1969, entered into force 27 January 1980).

Convention for Avoidance of Double Taxation and the Prevention of Fiscal Evasion with Respect to Taxes on Income and Capital, Switzerland-Germany, (11 August 1971, entered into force 29 December 1972).

Convention for Avoidance of Double Taxation on Income and Capital, Denmark-Switzerland (23 November 1973, entered into force 1 January 1974).

Convention for Avoidance of Double Taxation and the Prevention of Fiscal Evasion with Respect to Taxes on Income and on Capital Gains, Switzerland-Austria (30 January 1974, entered into force 4 December 1974). 
Convention for the Avoidance of Double Taxation and the Prevention of Fiscal Evasion with respect to Taxes on Income and on Capital, Canada-United States (26 September 1980).

Convention for Avoidance of Double Taxation and the Prevention of Fiscal Evasion with Respect to Taxes on Income and Capital Gains, the United Kingdom-the Netherlands (7 November 1980).

Convention for Avoidance of Double Taxation and the Prevention of Fiscal Evasion with Respect to Taxes on Income and Capital Gains, India-Mauritius (24 August 1982, entered into force 6 December 1983).

Directive 90/435/EEC on the common system of taxation applicable in the case of parent companies and subsidiaries of different Member States [1990] OJ L225.

Convention for Avoidance of Double Taxation and the Prevention of Fiscal Evasion with Respect to Taxes on Income and Capital Gains, the United Kingdom-India (25 January 1993, entered into force 25 October 1993).

Convention for Avoidance of Double Taxation and the Prevention of Fiscal Evasion with Respect to Taxes on Income, Switzerland-Luxembourg (21 January 1993, entered into force 19 February 1994).

Protocol to the Convention for Avoidance of Double Taxation and the Prevention of Fiscal Evasion with Respect to Taxes on Income, Canada-the Netherlands (4 March 1993, entered into force 30 July 1994).

Convention for the Avoidance of Double Taxation and the Prevention of Fiscal Evasion with respect to Taxes on Income and Capital, France-the United States (31 August 1994, entered into force 8 December 2004).

Convention for Avoidance of Double Taxation and the Prevention of Fiscal Evasion with Respect to Taxes on Income, Indonesia-Mauritius (10 December 1996, entered into force 12 January 1998).

United Nations Department of Economic and Social Affairs "United Nations Model Double Taxation Convention between Developed and Developing Countries" ST/ESA/PAD/SER.E/21 (2001).

Convention for Avoidance of Double Taxation and the Prevention of Fiscal Evasion with Respect to Taxes on Income, the Netherlands-Indonesia (29 January 2002, entered into force 1 January 2004).

Convention for Avoidance of Double Taxation and the Prevention of Fiscal Evasion with Respect to Taxes on 
Income, the Netherlands-Indonesia (29 January 2002, entered into force 1 January 2004). 